VILNIAUS GEDIMINO TECHNIKOS UNIVERSITETAS

Mindaugas STANIŪNAS

\title{
EKOLOGIJOS ASPEKTO VERTINIMAS MIESTŲ BENDRUOSIUOSE PLANUOSE
}

\section{DAKTARO DISERTACIJA}

TECHNOLOGIJOS MOKSLAI, STATYBOS INŽINERIJA (02T) 
Disertacija rengta 2009-2013 metais Vilniaus Gedimino technikos universitete.

\section{Mokslinis vadovas}

prof. dr. Marija BURINSKIENE (Vilniaus Gedimino technikos universitetas, technologijos mokslai, statybos inžinerija - 02T).

VGTU leidyklos TECHNIKA 2167-M mokslo literatūros knyga http://leidykla.vgtu.lt

ISBN 978-609-457-555-6

(C) VGTU leidykla TECHNIKA, 2013

(C) Mindaugas Staniūnas, 2013

mindaugas.staniunas@vgtu.lt 
VILNIUS GEDIMINAS TECHNICAL UNIVERSITY

Mindaugas STANIŪNAS

\section{ECOLOGICAL ASSESSMENT IN URBAN COMPREHENSIVE PLANS}

DOCTORAL DISSERTATION

TECHNOLOGICAL SCIENCES,

CIVIL ENGINEERING (02T)

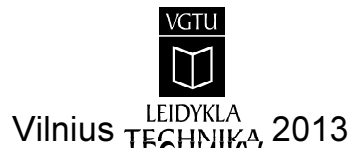


Doctoral dissertation was prepared at Vilnius Gediminas Technical University in 2009-2013.

\section{Scientific Supervisor}

Prof Dr Marija BURINSKIENE் (Vilnius Gediminas Technical University, Technological Sciences, Civil Engineering - 02T). 


\section{Reziumè}

XXI a. miestai labiau nei bet kada anksčiau yra siejami su verslo vystymo galimybemis, paslaugu teikimu, patraukliomis darbo ir gyvenamosiomis vietomis, tačiau tuo pat metu didejja susirūpinimas dèl miestų zonų aplinkos būklès. Miestuose susiduriama su panašiomis ekologinèmis problemomis ir kai kurios iš jų gali būti ịvardijamos kaip nuolatinès. Teritorijų planavimo dokumentų sprendinių poveikio vertinimas yra įtvirtintas įstatymais, tačiau nors ir yra žinoma, kad miestų plètra daro itaką gamtai, Lietuvoje nèra aiškios sistemos, leidžiančios kiekybiškai ịvertinti svarbiausius ekologinius rodiklius, be to, ir patys rodikliai nèra apibrèžti.

Tyrimo objektas - miesto ekologija, ją suvokiant kaip bendrosios ekologijos dalį, veikiančią ir veikiamą miestų aplinkoje. Darbo tikslas - pagerinti miestų bendrujų planų rengimo kokybę, itraukiant miesto ekologijos aspekto vertinimą. Disertaciją sudaro įvadas, trys skyriai, bendrosios išvados, literatūros ir autoriaus publikacijų disertacijos tema sąrašas.

Pirmas skyrius skirtas pradiniam ir esminiam planavimo aspektui aptarti juridinès planavimo pusès atskleidimui. Literatūros analizès metu buvo pastebètas vieningos europinès politikos miestų atžvilgiu nebuvimas, lietuviškos teritoriju planavimo teisinès bazès neapibrèžtumas ir didelis planavimo veiksmų laisvumas. Iš lietuviškų teisès aktų galima atrinkti / išvesti tam tikrus kiekybinius parametrus, tačiau įstatymuose nèra nustatytos rodiklių siektinosios vertès ir kaip tas vertes praktikoje specialistai galètų užtikrinti. Antrame skyriuje pasiūlytas miesto ekologijos modelis, kuris būtų tinkamas planavimo specialistams ir sudarytu prielaidas efektyviau valdyti pagrindines miestu ekologijos problemas. Modelis orientuotas i kiekybinį vertinimą ir, atsižvelgiant i poveikio krypti, yra sudarytas iš dviejų pagrindinių dalių: išorinès ir vidinès miesto ekologijos. Ivertinus, kad miestų itaka pasauliniams ekologiniams procesams yra mažai tyrinèta, detalesnei analizei buvo pasirinkta būtent išorinė miesto ekologija. Remiantis tarptautiniais teisiškai ịpareigojančiais susitarimais, nustatytos ribinès vertės - emisijų mažinimas nuo $8 \%$ iki $30 \%$. Trečias skyrius skirtas atliekų tvarkymo ir energetikos sektorių integravimui i planavimo praktiką. Sektoriu emisijos susietos su planuojant naudojamais kiekybiniais parametrais ir nustatytais emisiju mažinimo tikslais. Apskaičiuota, kad miestų bendruju planų galiojimo laikotarpiu statistinis gyventojas išmes tokị komunalinių atliekų kiekį, kurio ekologinès žalos kompensavimui reikalinga 200 $\mathrm{m}^{2}$ želdynų teritorija. Energetikos sektoriuje, pritaikius siūlomus sprendimus, ekologinę žalą galima ne tik kompensuoti, bet ir ją sumažinti daugiau kaip $30 \%$.

Pasiūlytu modeliu tikslinama miesto ekologijos struktūra ir komponentai, sudaromos prielaidos kiekybini vertinimą įtraukti ị planavimo praktiką. 


\section{Abstract}

In the 21st century, cities have more than ever been associated with the possibilities of business development, favourable workplaces and residence, yet there is growing concern about the environmental condition of city zones. In cities one faces similar ecological issues and some of them can be named as constant. The assessment of territorial planning document solutions is confirmed by laws; it is, however, known that urban development affects the environment; in Lithuania there is no clear system allowing one to quantitatively assess the essential ecological indicators, and the indicators themselves are not defined.

The object of the work is the ecology of city being understood as a part of general ecology. The aim of the research is to improve the quality of preparation of urban comprehensive plans, incorporating the assessment of ecology of city. The dissertation comprises Introduction, three Parts, general conclusions, the list of literature and author's published works on the topic of the dissertation.

Part One is dedicated to investigating the primary and essential aspect of planning - to disclose the legal aspect of planning. During the analysis of literature one noticed the absence of the united European policy in terms of cities, indefiniteness of the Lithuanian territorial planning legal basis and plenty of freedom to act in the sphere of planning. In Part Two the model of ecology of city has been proposed which could be suitable for the specialists in the sphere of planning and would allow managing the fundamental issues of city ecology. The model focuses on quantitative assessment and, having regard to the impact trend, comprises the main two parts: external and inner ecology of city. Having determined that the impact of cities on the world's ecological processes has little been investigated, the external ecology of city has been selected for deeper analysis. Referring to international agreements of legal obligation, exposure limits have been established: reduction of emissions from 8-30\%. Part Three is devoted to integration of waste management and energy sectors into the practice of planning. The emissions of the mentioned sectors are interconnected with quantitative parameters used in planning and with the aims, set in the dissertation, of emissions reduction. It has been estimated that during the validity of urban comprehensive plans the statistical person will generate such amount of municipal waste whose compensation of ecological damage requires the area of $200 \mathrm{~m}^{2}$ of green plantations. In the energy sector, having applied the proposed decisions, ecological damage can not only be compensated but also lessened more than $30 \%$.

The proposed model concretizes the structure of ecology of city and its components, allows integrating quantitative assessment into the practice of planning. 


\section{Žymèjimai}

\section{Simboliai}

$b_{i j}-i$ varianto $j$ rodiklio didesnioji vertè (taikoma pilkiesiems skaičiams);

$m$ - variantų skaičius;

$n$ - rodiklių skaičius;

$q_{j}-j$ rodiklio santykinis reikšmingumas;

$w_{i j}-i$ varianto $j$ rodiklio mažesnioji vertè (taikoma pilkiesiems skaičiams);

$x_{i j}-i$ varianto $j$ rodiklio verté; $i=1,2, \ldots \mathrm{m} ; j=1,2, \ldots \mathrm{m}$;

$\bar{x}_{i j}-i$ varianto $j$ rodiklio normalizuota verté;

$\overline{\bar{x}}_{i j}-i$ varianto $j$ rodiklio svertinè normalizuota verte;

$x_{j}^{\max }-j$ rodiklio didžiausia verte;

$x_{j}^{\min }-j$ rodiklio mažiausia vertè.

\section{Santrumpos}

ES - Europos Sajunga;

JT - Jungtinès Tautos;

LR - Lietuvos Respublika;

COPRAS - daugiakriterinio kompleksinio proporcingumo metodas (angl. Complex Proportional Assessment of Alternatives);

COPRAS-G - daugiakriterinio kompleksinio proporcingumo metodas su pilkaisiais skaičiais (angl. Complex Proportional Assessment of Alternatives with Grey Number); 
SAW - paprastojo svorių sudèjimo metodas (angl. Simple Additive Weighting);

SAW-G - paprastojo svorių sudejjimo metodas su pilkaisiais skaičiais (angl. Simple Additive Weighting with Grey Number);

TOPSIS - artumo idealiam taškui metodas (angl. Technique for Order Preference by Similiarity to Ideal Solution);

TOPSIS grey - artumo idealiam taškui metodas su pilkaisiais skaičiais (angl. Technique for Order Preference by Similiarity to Ideal Solution with Grey Number);

WASPAS - svorinès agreguotos sumos metodas (angl. Weighted Aggregated Sum Product Assessment). 


\section{Turinys}

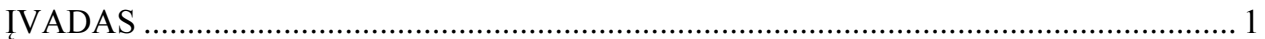

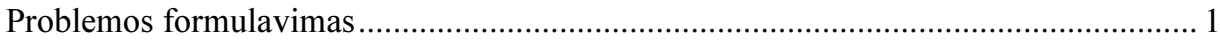

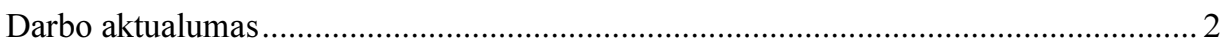

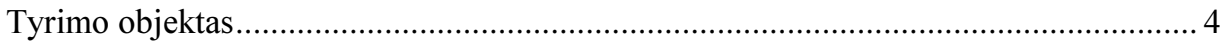

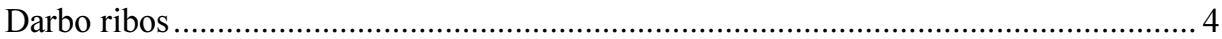

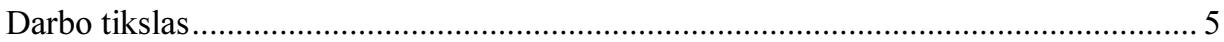

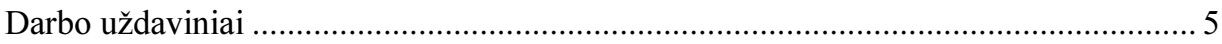

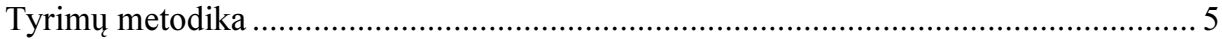

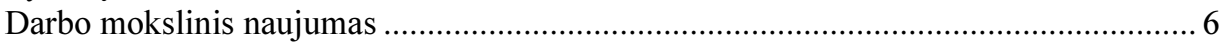

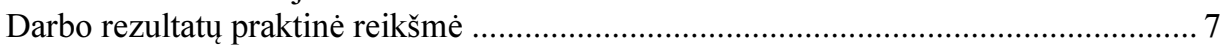

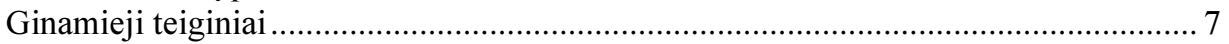

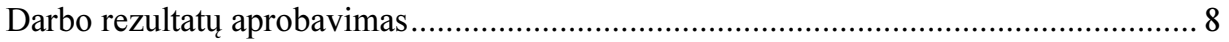

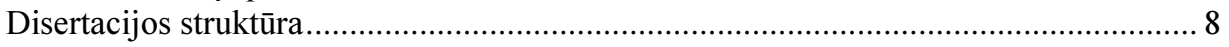

1. MIESTO EKOLOGIJA IR PLANAVIMAS: MOKSLINĖ IR TEISINĖ PRIEIGA ...... 9

1.1. Miesto ekologija mokslineje literatūroje …………........................................ 10

1.2. Miestų planavimo reglamentavimas Europos Sajungos teisèje ............................ 15

1.3. Pagrindiniu Lietuvos Respublikos teritorijų planavimo dokumentų analizè ......... 21

1.4. Kiekybiniai parametrai Lietuvos Respublikos teritorijų planavimo

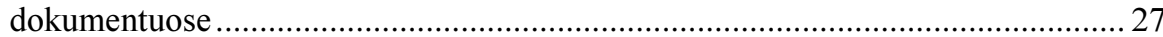

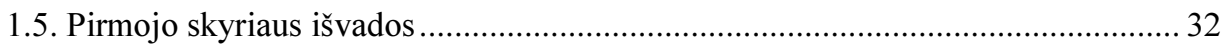


2. MIESTO EKOLOGIJOS MODELIS: STRUKTŪRA IR RIBOS ............................. 33

2.1. Miesto ekologijos procesų specifika................................................................ 34

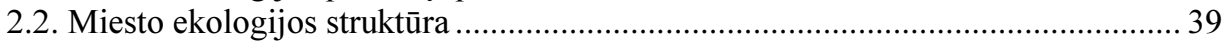

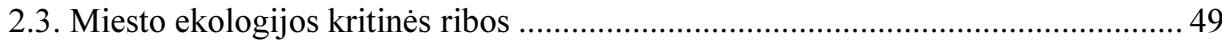

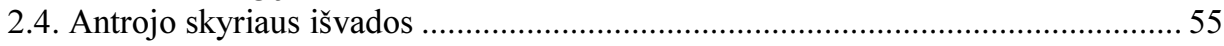

3. IŠORINĖS MIESTO EKOLOGIJOS MODELIO PRAKTINIS PRITAIKYMAS ...... 57

3.1. Komunalinių atliekų sektoriaus integravimas ị miestų planavimo ekologiją ........ 58

3.2. Energetikos sektoriaus integravimas į miestų planavimo ekologiją ......................6 68

3.3. Energetikos sektoriaus pertvarkymų poveikio išorinei miesto ekologijai

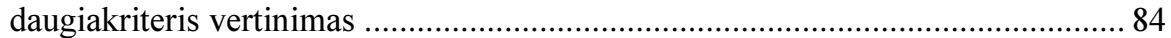

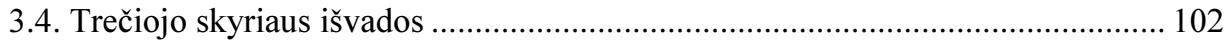

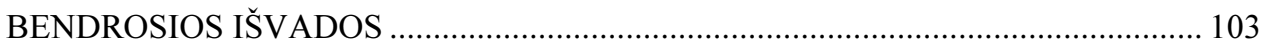

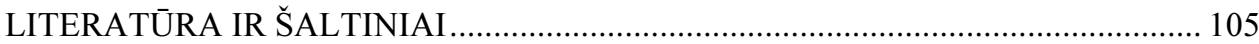

AUTORIAUS MOKSLINIŲ PUBLIKACIJŲ DISERTACIJOS TEMA SĄRAŠAS ... 121 


\section{Contents}

INTRODUCTION

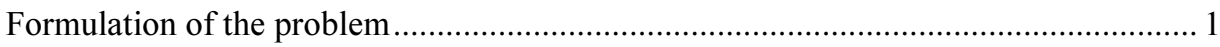

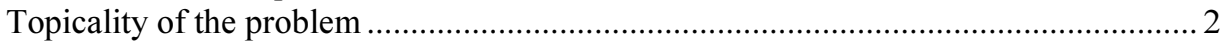

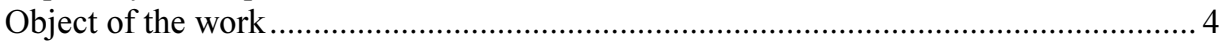

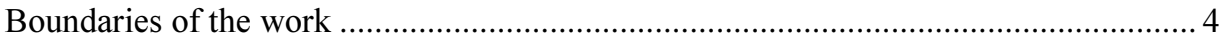

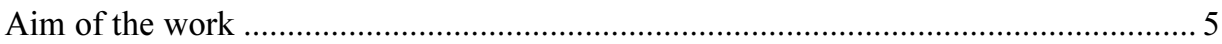

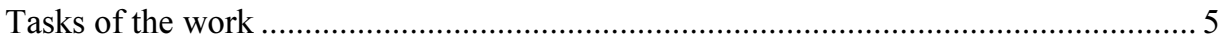

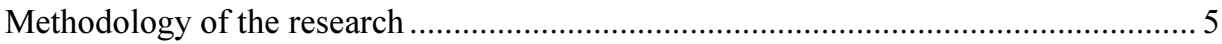

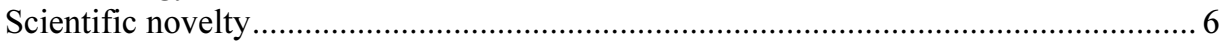

Practical value of the findings of the research work ...................................................... 7

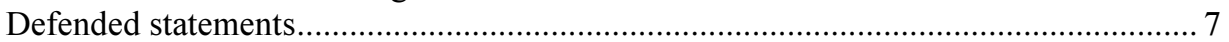

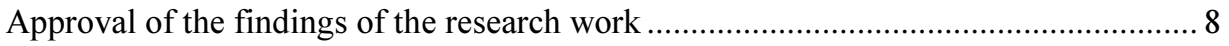

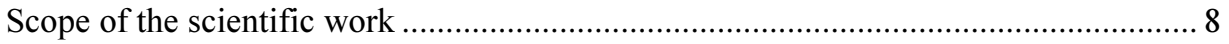

1. ECOLOGY OF CITY AND PLANNING: SCIENTIFIC AND JURIDICAL

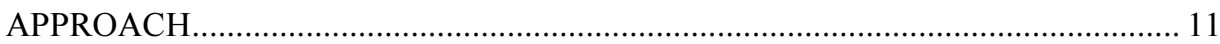

1.1. Ecology of city in scientific literature ……………......................................... 12

1.2. Urban planning regulations of the European Union law ...................................... 17

1.3. The analysis of the main documents of the Lithuanian Republic territorial planning 
1.4. Quantitative parameters in the Lithuanian Republic territorial planning documents

1.5. Conclusions of the first chapter ....................................................................... 32

2. MODEL OF THE ECOLOGY OF CITY: STRUCTURE AND BOUNDARIES......... 33

2.1. The particularities of processes of ecology of city ................................................ 34

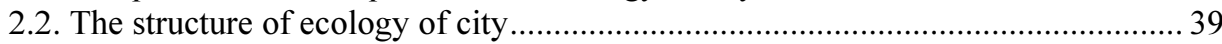

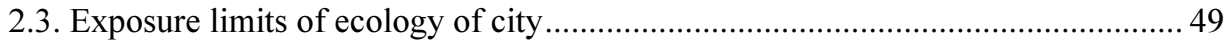

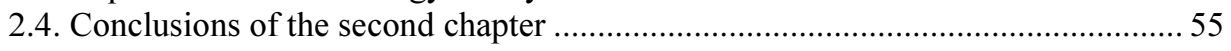

3. PRACTICAL APPLICATION OF THE MODEL OF EXTERNAL ECOLOGY OF

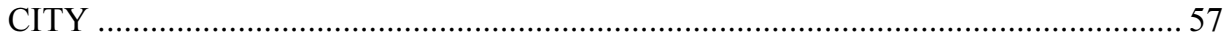

3.1. Integration of the municipal waste sector into the ecology of urban planning ...... 58

3.2. Integration of the energy sector into the ecology of urban planning ...................... 68

3.3. Multi-criteria assessment of the impact of energy sector reforms on external city

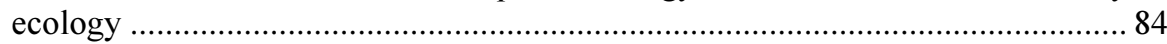

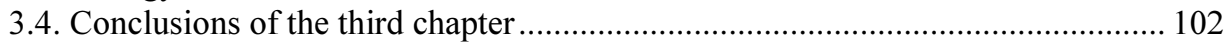

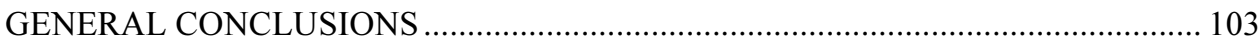

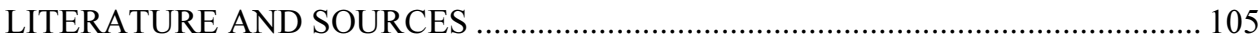

LIST OF THE AUTHOR'S SCIENTIFIC PUBLICATIONS ON

THE TOPIC OF THE DISSERTATION 


\section{Ivadas}

\section{Problemos formulavimas}

Šiuolaikiniame pasaulyje labiau nei bet kada anksčiau miestai yra siejami su verslo vystymo galimybèmis, paslaugu teikimu, patraukliomis darbo ir gyvenamosiomis vietomis, tačiau tuo pat metu dideja susirūpinimas dèl miestų zonų aplinkos būklès. Iš esmès miestuose susiduriama su panašiomis ekologinemis problemomis, tokiomis kaip oro ir vandens tarša, padidejęs triukšmo lygis ar šiltnamio efektą sukeliančių dujų emisijos. Kai kurios rimtos ekologinès problemos jau gali būti įvardijamos kaip nuolatinès (išliekančios), be to, iškyla naujos, todèl planuojant miestų plètrą - nesvarbu, ar nukreiptą i vidines teritorijas, ar i priemiestines zonas, - būtinas ekologiniu pasekmių tyrimas.

Teritoriju planavimo dokumentų sprendinių poveikio (drauge ir poveikio aplinkai) vertinimas yra itvirtintas įstatymais, tačiau nors ir yra žinoma, kad miestų plètra daro įtaką gamtai, nèra aiškios sistemos, leidžiančios kiekybiškai ivertinti kertinius ekologinius aspektus, be to, ir patys aspektai nèra apibrežti. Bandant ịvertinti miestų plètros poveikị, sprendžiama tiek vertinimo struktūros, tiek ir rodiklių parinkimo problema. Teoriškai toks uždavinys galètų būti sprendžiamas daugiakriterio vertinimo metodais, ịvertinant visus reikalingus rodiklius, tačiau realiame pasaulyje sistema būtų ypač komplikuota ir imli laikui, 
o planavimo procedūrų atlikimo laikas yra apibrèžtas norminiuose dokumentuose ir papildomo laiko modeliavimui nèra numatyta. Pats planavimo norminimo faktas parodo, kad planavimas (bent iš dalies) - juridinis procesas, kuris turi būti vykdomas vienodomis sąlygomis visoje Lietuvos Respublikos teritorijoje, t. y. vieninga, unifikuota struktūra yra privaloma. Skirtingų specialistų individualiai siūlomos naujos vertinimo struktūros, viena vertus, parodo, kad tinkamos struktūros vis dar nèra, tačiau, kita vertus, pateikia (dažniausiai) perteklinès ir neesminès informacijos, kuri tik dar labiau ,išpučia“ visą vertinimo sistemą ir atitinkamai užmaskuoja svarbiausius rodiklius.

Naudojantis teritorijų planavimo teisine baze kaip pagrindiniu išeities tašku, disertacijoje numatoma spręsti miesto ekologijos struktūros ir jos komponentų kiekybinio vertinimo problemą. Laukiamas rezultatas, kuris leistų matematiškai ivvertinti miestų bendruju planų poveiki miestų ekologijos aspektu, t. y. leistų ekologinị indèli (teigiamą ir / ar neigiamą) ịvertinti kiekybiškai praktikoje realiomis sąlygomis.

\section{Darbo aktualumas}

XVIII a. pab. prasidejjusi industrinè revoliucija XIX šimtmetyje jau buvo apemusi visas pagrindines Europos valstybes. Metalo apdirbimas, garo energija, fabrikų sistemų susiformavimas, naujos transporto priemonès (geležinkeliai, garlaiviai), sunkioji pramonè, sudètingèjanti inžinerija, centralizacija, standartizacija ir urbanizacija tapo nebeatskiriama žmoniu gyvenimo dalimi. Ilgainiui elektra ir nafta tapo pagrindiniais pramonès augimą užtikrinančiais energetiniais šaltiniais, o miestai - darbo jègos ir drauge produkcijos realizavimo garantu.

Urbanizacijos procesas taip įsitvirtino, kad net praejjus daugiau negu šimtui metų jis vis dar progresuoja: miestas standartiškai suvokiamas kaip gyvenamosios bei darbo vietu atitikmuo beveik visame civilizuotame pasaulyje, ir „homo sapiens urbanus yra tapęs norma“ (EC 2010a). Jungtinių Tautų duomenimis (UN 2010), $2010 \mathrm{~m}$. daugiau kaip pusė viso pasaulio gyventojų jau buvo miestiečiai, atskiruose regionuose ši dalis dar didesnè, pavyzdžiui, Europos Sajungoje urbanizuotose teritorijose gyvena daugiau kaip $70 \%$ žmonių (Eurostat 2012), teigiama, kad pasaulio „miestejjimas“ tęsis ir ateityje (UN 2010). Absoliučiai daugumai žmonių miestas yra ir išliks pačia populiariausia gyvenamaja vieta: gyvenimas mieste reiškia aukštesnius gyvenimo standartus ir gerovę. Kita vertus, kieno naudai?

Urbanizacija kaip ir pramonè yra neatsiejama nuo tokių reiškinių kaip intensyvus energijos ir natūralių išteklių vartojimas, oro ir vandens tarša, triukšmas, atliekos ir pan. Apie gerovès bei pramonès progreso faktišką (tame 
tarpe ir netiesioginę) kainą ir ekologines pasekmes pradèta kalbèti apie 1960 metus, tačiau tuomet politikams, visuomenei, žiniasklaidai dalies mokslininkų prognozuojamas ekoarmagedonas pasirode tolimas, neįikinantis, ginčytinas ir, be abejo, nepalankus. Paradoksalu, tačiau manoma, kad viena iš pagrindinių priežasčių, leidusių sustiprèti aplinkos apsaugos politikai, buvo ne kas kita, o „gerovès“ - naftos - stygius, kai aštuntajame dešimtmetyje, nutrūkus naftos tiekimui iš Viduriniujų Rytų, drastiškai pašoko kainos (Steele 2005). Išaugusios kainos ir kilęs žmonių nepasitenkinimas vertẻ politikus svarstyti resursų taupymo, savęs išlaikymo, vietinių energetinių išteklių panaudojimo ir panašius klausimus. Be to, maždaug 1985-1990 metais buvo pasiekta Žemès galimybių riba, vèliau virtusi (tebesitęsiančiu dabar) pereikvojimu - žmonijos poreikiai viršijo planetos regeneracines galimybes (Wackernagel and Monfreda 2004; Wackernagel et al. 2005; Borucke et al. 2013). Besitęsiant gamtinių resursų pereikvojimui ir ryškejjant drastiškoms pasekmèms, tapo aišku, kad poreikius ir vartojimą reikia riboti - tik klausimas kaip?

1972 metais publikuota ataskaita „Augimo ribos“ (Limits to Growth) pabrěžè, kad tolesnis sparčiai progresuojantis natūralių resursų vartojimas prives prie negrižžtamo jų praradimo ir išpopuliarino daug debatų sukèlusią „nulinio augimo“ (zero growth) koncepciją. Audringas diskusijas kèlęs klausimas - ar ekonomikos progresas yra būtinas norint užtikrinti (finansuoti) aplinkos apsaugą, ar visgi ekonomikos progreso neišvengiamas rezultatas yra gamtos nualinimas ir atliekos? - buvo korektiškai išspręstas 80-ųų pabaigoje pasiūlius darnumo koncepciją. Darnumo sąvoka, apimanti tris kertinius komponentus socialini vystymąsi, ekonomikos progresą ir ekologiją, - tapo tikra panacèja politiniame lygmenyje, nes leido sujungti iki tol nesuderinamus dalykus. J. M. Barosso - Europos Komisijos prezidentas - yra pasakęs, kad „Europos Sajunga tvirtai pasisako už darnų vystymąsi. Tai pagrindinis politikos ir veiksmų principas tiek ES viduje, tiek tarptautineje arenoje“ (Wackernagel et al. 2005).

Darnaus vystymosi koncepcija pasiūle teorini suderinamumo principą, tačiau nenurodè, kaip ji praktiškai igyvendinti. Praejjo daugiau kaip 20 metų, o faktiškai darnumo dar niekur nepavyko pasiekti (Millenium Ecosystem Assessment 2005). Apibendrinant galima teigti, jog esama situacija kontroversiška: problema svarbi ir aiški - gamtiniu galimybių pereikvojimas, sprendimo būdas irgi žinomas - darnus vystymasis, tačiau faktiškai tikslas neigyvendintas.

Siekiant realaus disertacijos naudingumo tiek praktiniu, tiek moksliniu aspektais, būtų naudinga darnų vystymąsi analizuoti ne kaip nedalomą vieni, o kaip atskiru dalių jungini. Tikslingiausia dirbti tose vietose, kur numatomas poveikis didžiausias, todèl darbo metodologiniu pagrindu pasirinkta tik viena darnumo sudedamoji dalis - ekologija, kuri tiriama tik vienoje terpejje - mieste. Tokị derini nulèmè aukščiau išdèstyta informacija, t. y. gamtos pereikvojimo 
faktas reikalauja neatidèliotino ekologinių problemų sprendimo, ir būtent „miestuose iškyla daugiausia aplinkos apsaugos problemų", be to, lemiamą vaidmeni gerinant miesto aplinką igauna vietos valdžia, t. y. savivaldybès (KOM(2005) 718 galutinis). Lietuvoje savivaldybès pagrindines miesto teritorijos valdymo gaires užtikrina dalyvaudamos rengiant miestų bendruosius planus, todèl disertacijoje analizuojamas vienas aktualiausių šiandienos ekologinių klausimų - kaip ir kokios ekologinès problemos gali (turi) būti sprendžiamos rengiant miestų bendruosiuos planus? Šio klausimo sprendimas aktualus tiek mokslo krypčiai ir specialistams, tiek valstybei vietiniu, nacionaliniu ir tarptautiniu lygmenimis.

\section{Tyrimo objektas}

Tyrimo objektas - miesto ekologija, ją suvokiant kaip bendrosios (ne socialinès) ekologijos dali, veikiančią ir veikiamą miestų aplinkoje. Pasirinkus ši objektą kaip mokslinès pažintinès veiklos dalyką, darbe analizuojami jos pagrindinių komponentų atrinkimo, principinès struktūros formavimo ir kiekybinio ivertinimo galimybès bei ypatumai. Darbe nagrinejami tik tie ekologiniai parametrai, kurie yra kertiniai, t. y. tie, kurių keitimas (valdymas) susijęs su dideliais, esminiais pokyčiais ir tie, kurie gali būti panaudoti rengiant bendruosius miestų teritorijų planavimo dokumentus (miestų bendruosius planus). Kitais žodžiais, miestų bendruosiuose planuose sprendžiami tam tikri specifiniai klausimai, kurių konkretizavimo lygis yra ribojamas techninių ir / ar juridinių veiksnių, pavyzdžiui, planuojamos teritorijos dydžio, todèl ịvertinimo detalumas (rodiklių skaičius ir pan.) ir tikslingumas turi būti atitinkamai pakoreguoti: sustambinti ir apibendrinti.

\section{Darbo ribos}

Atsižvelgiant i tyrimo problemą ir darbo aktualumą, disertacijoje pristatomas visapusiškas miesto ekologijos modelis, kurị bendrosios ekologijos apimtyje siūloma suvokti kaip dviejų dalių junginį. Dalys, vertinant pagal poveikio kryptį, darbe vadinamos išorine miesto ekologija ir vidine miesto ekologija (detaliau žiūr. III skyrių). Darbas orientuotas i išsamų išorinès miesto ekologijos (išskyrus pramonès ir transporto sektorius) konstravimą, o vidinè miesto ekologija aptariama tik iš dalies, tiek, kiek reikia konstruojamo modelio suvokimui (išsamesnius sprendimo motyvus detaliau žiūr. 2.2 poskyrị). Siekiant praktinių darbo rezultatų pritaikymo, disertacijoje ne tik atskleidžiami pasirinktos miesto ekologijos dalies komponentai, pasiūlomos formulès šių komponentų 
kiekybiniam ivertinimui, bet ir pateikiami realaus praktinio pritaikymo pavyzdžiai. Darbas skirtas Lietuvos miestų bendrujų planų tobulinimo aktualijoms atskleisti.

\section{Darbo tikslas}

Darbo tikslas - pagerinti miestų bendrujų planų rengimo kokybę, įtraukiant miesto ekologijos aspekto vertinimą.

\section{Darbo uždaviniai}

1. Atlikti mokslinès literatūros, Europos Sajungos teisinio reglamentavimo, susijusio su miestų planavimu, pagrindinių veikimo principų ir Lietuvos istatyminès bazès, reglamentuojančios miestų planavimo ekologini aspektą, analizę.

2. Remiantis Lietuvos teritorijų planavimą reglamentuojančiais ịstatymais, sudaryti kiekybinių rodikliu, naudojamų planavimo metu, klasifikuotą sąrašą.

3. Pasiūlyti bendrają miesto ekologijos struktūrą ir ją apibūdinančius esminius parametrus.

4. Sukurti kiekybinę išorinès miesto ekologijos vertinimo sistemą, kurią galima naudoti planavimo proceso metu, ir pateikti vertinimo praktiniu pavyzdžių.

\section{Tyrimų metodika}

Pagrindinè ideja, kuria remiantis buvo sumanytas tyrimas, įvertinti ekologiją apibūdinančių kiekybinių parametrų taikymo galimybę, rengiant miestų bendruosius planus. Dabartiniu metu dažniausiai taikoma praktika aprašomasis, kokybinis vertinimas, todèl gaunami daugiaprasmiai, tarpusavyje objektyviai nepalyginami rezultatai. Be to, gauti rezultatai labai priklauso nuo planą rengusių specialistų valios. Atsižvelgiant ị minètus trūkumus ir faktą, kad miestų planavimas - teisinè procedūra, esminiai du tyrimo klausimai yra šie:

1. ar miesto ekologijos sąvoka yra tinkamai apibrèžta moksliškai arba juridiškai, t. y. ar egzistuoja kiekybiniai miesto ekologijos parametrai? 
2. ar esamus miesto ekologijos parametrus galima taikyti, rengiant bendruosius planus, t. y. ar reikalingas rodikliu pritaikymas praktiniam naudojimui?

Darbe naudoti trys tyrimo metodai: teorinè analizè, apibendrinimas ir testavimas. Teorinès analizès metu atlikta šiuolaikinès mokslinès literatūros ir teisinių šaltinių apžvalga, apibendrinimo metu - minètos informacijos kritinis vertinimas, siekiant nustatyti informacijos validumą, t. y. patikimumą ir tinkamumą praktinèje veikloje. Papildomai atsižvelgta i statistinius duomenis. Darbo pabaigoje pateikti pasiūlytų sprendimų testavimo pavyzdžiai (kontroliniai skaičiavimai).

Pagrindinis visų duomenų šaltinis - elektroninès (interaktyvios) duomenų bazès, kurios pasirinktos dèl jose pateikiamos informacijos įvairiapusiškumo, spartaus atnaujinimo ir gausos. Teisiniai dokumentai skaityti oficialiose Europos Sajungos, Lietuvos Respublikos Seimo, Vyriausybès ir Aplinkos ministerijos internetinèse svetainèse. Statistiniai duomenys paimti iš LR Statistikos departamento ir Eurostat internetinių svetainių / leidinių. Trečiame skyriuje pateikti miestų planų fragmentai parengti AutoCAD programa, naudojant interneto žemėlapių svetainių duomenis, rezultatai buvo papildomai patikrinti atliekant kontrolinis matavimus Vilniuje.

\section{Darbo mokslinis naujumas}

Teoriniu požiūriu ekologinio vertinimo koncepcija nèra nauja: XX a. pab. - XXI a. ją plètoja tiek pavieniai specialistai, tiek valstybinès ir tarptautinès organizacijos (žiūr. darbo aktualumas). Tokios situacijos rezultatas daugybè skirtingų modelių, ivvairių rodiklių, indikatorių ir pan., todèl dar vienas vertinimo metodas būtų teoriškai naujas, tačiau faktiškai labai greitai pranyktų ir taip nebeapdorojamoje parametrų maseje. Siekiant to išvengti, darbe vadovautasi kitokiu metodologiniu požiūriu: stengtasi apibendrinti ir išgryninti esamus agreguotus duomenis, ir būtent tame gebejime atsitraukti, abstrahuoti ir pateikti visuminị vaizdą (ivertinimą) slypi darbo reikšmè. Darbo rezultatas - aiški loginè struktūra, principinis karkasas, paremtas jau turimais duomenimis. Darbas orientuotas ne $\mathrm{i}$ kiekybinị informacijos plètimą, dauginimą, bet priešingai - $\mathrm{i}$ kokybinę struktūrą. Gautas rezultatas ne tik atskleidžia, kokie veiklos barai ištirti detaliau, kur dar stinga duomenų, tačiau parodo informaciją loginès struktūros fone. Miestų ekologijos ir miestų bendrujų planų sąsajos Lietuvoje išsamiai nenagrinètos, todèl darbas paaiškina (praplečia) šią mokslo krypties veiklą ir pasiūlo jos karkasą. 
1. Remiantis moksline ir teisine informacija, nustatyta, kokios yra pagrindinès miesto ekologijos vertinimo problemos, su kuriomis susiduriama rengiant miestų bendruosius planus.

2. Sudarytas bendras miesto ekologijos modelis. Modelis, vertinant pagal poveikio kryptị, susideda iš išorinès ir vidinès miesto ekologijos.

3. Pasiūlytas skaičiavimo metodas, leidžiantis išorinę miesto ekologiją ivertinti rengiant miestų bendruosius planus. Modelis paremtas kiekybiniais rodikliais, t. y. gaunamas objektyvus rezultatas.

\section{Darbo rezultatụ praktinẻ reikšmè}

Disertacijos metu parengta miesto ekologijos samprata ir ypač kiekybinè išorinès miesto ekologijos vertinimo sistema gali būti praktiškai taikomos rengiant miestu bendruosius planus. Tai yra priemone, leidžianti planuotojams matematiškai išorinès miesto ekologijos aspektu įvertinti bendrojo plano poveiki ir / arba palyginti skirtingus miestu plètros variantus, kurios déka tampa imanomas objektyvus sprendimų pasirinkimas. Sukurtas skaičiavimo modelis nereikalauja papildomos pradinès informacijos, užtenka tos, kuri iprastai naudojama rengiant teritoriju planavimo dokumentus. Autoriaus žiniomis, kito tokio praktiškai funkcionuojančio modelio Lietuvoje nèra. Darbas yra naudingas vertinant ir visos valstybès lygmeniu kaip šios srities savianalizès priemonè bei dèl aiškesnès Lietuvos miestų itakos pasauliniams ekologiniams procesams atskleidimo. Pasiūlytas modelis tinkamas Lietuvos miestams, tačiau teorinè bazé buvo parengta remiantis Eropos Sajungos dokumentais, susijusiais su planavimu ir ekologija, todèl modelị galima keisti ir taikyti kitų ES šalių narių teritorijose.

\section{Ginamieji teiginiai}

1. Miestų ekologija pagal poveikio krypti yra dvipusè: išorinè ir vidinè. Išorinès ekologijos procesai visiems miestams vienodi - tai yra globalūs ekologiniai procesai, darantys esminę ịtaką už miesto ribų; o vidinès gali būti ịvairesni, nes tai yra lokalūs procesai, darantys esminę ịtaką miesto viduje.

2. Planuojant miestus svarbūs tik ties kritinèmis ribomis atsiduriantys miesto ekologijos procesai. Miestų planavimas - teisinè procedūra, todèl išorinės ekologijos kritinès ribos turi būti maksimaliai suvienodintos ir itvirtintos juridiškai. 
3. Lietuvoje efektyviam miesto ekologijos aspekto integravimui i miestu bendrujų planų rengimą ir progreso ịvertinimui, kritinių ribų atskaitos pradžia turi būti laikoma planavimo procedūrų pradžia.

\section{Darbo rezultatų aprobavimas}

Disertacijos tema yra publikuoti septyni moksliniai straipsniai, iš kurių vienas paskelbtas „ISI Web of Science“ leidinyje, turinčiame citavimo rodikli (Staniūnas et al. 2013), vienas - „ISI Master Journal List“ (Staniūnas et al. 2010), du - tarptautiniu duomenu baziu (EBSCOhost, CABI, CSA, TOC Premier) leidiniuose (Staniūnas 2012; Staniūnas et al. 2012), vienas - „ISI Proceedings" leidinyje (Staniūnas and Burinskienè 2011a) ir kompaktiniame diske (Staniūnas and Burinskienè 2011b), vienas - recenzuojamoje tarptautiniu konferecijų medžiagoje (Staniūnas and Staniūnas 2011). 2012 m. publikuotas straipsnis (Staniūnas et al.) įtrauktas ì Europos Komisijos aplinkos apsaugos politikos tyrimų saugyklą.

Disertacijoje atliktų tyrimų rezultatai buvo paskelbti penkiose mokslinėse konferencijose Lietuvoje ir užsienyje:

- 13-ojoje Lietuvos jaunųu mokslininkų konferencijoje „Mokslas Lietuvos ateitis " $2010 \mathrm{~m}$. Vilniuje;

- 8-ojoje tarptautineje konferencijoje „Environmental engineering“ $2011 \mathrm{~m}$. Vilniuje;

- Tarptautinëje konferencijoje „Ecological Architecture 2011“ 2011 m. Kaune;

- Tarptautinëje konferencijoje „Advanced Construction 2012“ 2012 m. Kaune;

- Tarptautineje konferencijoje „European Union external border territorial specificities, trends and disparities “ 2013 m. Tartu (Estija).

\section{Disertacijos struktūra}

Disertaciją sudaro ivvadas, trys skyriai: 1) miesto ekologija ir planavimas: mokslinè ir teisine prieiga, 2) miesto ekologijos modelis: struktūra ir ribos, 3) išorinès miesto ekologijos modelio praktinis pritaikymas, bei išvados. Darbo apimtis yra 136 puslapiai, darbe - 30 lentelių ir 20 paveikslų. Literatūros sąraše - 187 darbe naudotos literatūros punktai. 


\section{1}

\section{Miesto ekologija ir planavimas: mokslinè ir teisinè prieiga}

Teritorijų planavimas yra procedūra, apibrèžiama ir vykdoma pagal tam tikrus norminius aktus ir kurios rezultatas yra teisiškai validus. Tuo pačiu metu planuojant dažnai igyvendinami sprendimai, kurių ištakos siekia mokslinius tyrimus, skirtus ịvairių procesų, vykstančių mieste, analizei. Siekiant praktiškai susieti teritorijų planavimą su miestų ekologija, tiek dabartinių mokslinių žinių, tiek teisinès struktūros ir aktų pavaldumo ryšių nustatymas yra būtina prielaida. Lietuvoje teritoriju planavimą reglamentuoja LR teisès aktai, tačiau be nacionalinių teisinių dokumentų Lietuva turi ir tarptautinių įsipareigojimų: 2004 m. kartu su kitomis penktosios bangos valstybèmis Lietuva tapo ES šalimi nare. Be to, 2013 m. liepos 1 - gruodžio 31 dienomis Lietuva pirmininkaus ES Tarybai. Taigi, Lietuvoje galioja ES normatyvai. Bendroji ES teise skirta visos bendrijos reikalams ir nereglamentuoja kiekvienos valstybès teritorijų planavimo ar tuo labiau miestų planavimo politikos. Tačiau ES būdinga nustatyti tam tikras bendras veiklos gaires, kurios reikalingos sklandžiam ir vieningam visos bendrijos funkcionavimui. Europinio teisès modelio struktūros ir veikimo atskleidimas toks pat reikalingas kaip ir detali LR teisès aktų, susijusių su planavimu, analizè. Pirmas skyrius skirtas esamos būklès mokslinių žiniu ir teisinių (ES ir LR) svertų kritiniam aptarimui, akcentuojant praktinę planavimo 
pusę. Šio skyriaus tema publikuoti du straipsniai (Staniūnas et al. 2010; Staniūnas and Staniūnas 2011).

Darbui aktualūs literatūros ir šaltinių pasirinkimo kriterijai.

Integralumas. Miestų planavimas - sritis, sujungianti daug disciplinų. Šiuo metu išsivysčiusiose valstybėse dominuojanti planavimo kryptis vienaip ar kitaip susijusi su darniu vystymusi ir jo igyvendinimu miestu aplinkoje. Renkantis medžiagą, i vyraujančias nuostatas buvo atsižvelgta, todèl prie ekologinių klausimų pereita trumpai pristačius darnaus vystymosi populiarumo pasekmes.

Praktinis pritaikymas. Vienas iš disertacijos siekių yra praktinis rezultatų taikymas, todèl analizuojant literatūrą ypatingas dèmesys buvo skirtas mokslinių žinių taikymui realiame gyvenime ir sunkumams, kurie atsiskleidžia nagrinèjant šiuolaikines duomenu bazes. Šiuo atveju kalbama ne tiek apie konkrečius pavienių mokslininkų nagrinejjamus klausimus ar vykdomus tyrimus, kiek apie bendrają dabartiniu metu vyraujančią mokslo publikavimo tendenciją ir su tuo sietinas praktikoje atsiskleidžiančias problemas.

Naujumas. Didžioji dalis apžvalgai naudotų duomenų gauti iš šiuolaikinių elektroninių duomenų bazių, atrinkti nauji reikiama tema publikuoti darbai. Didžiają dalị medžiagos sudaro straipsniuose skelbta medžiaga.

Juridinè planavimo pusé - neatskiriama planavimo dalis, svarbiausi teisiniai dokumentai aptarti 1.2 ir 1.3 poskyriuose, tačiau iš esmès i juridini aspektą ir oficialius statistinius duomenis remtasi rašant visą darbą.

\subsection{Miesto ekologija mokslinèje literatūroje}

Ivade buvo minèta, tačiau svarbu dar kartą pabrèžti, kad darbe analizuojama bendroji ekologija specifinejje - miestu - aplinkoje, šios ekologijos krypties nederètu painioti su socialine ekologija. I visuomeninius (socialinius) procesus ekologija itraukta $1921 \mathrm{~m}$. (Vanagas 1992). Lietuvoje tiek sovietiniais metais, tiek ir atkūrus Nepriklausomybę bene išsamiausius (ilgalaikius, paremtus praktiniais stebejimais ir aktualius miestų planavimui) socialinès ekologijos tyrimus vykde ir rezultatus publikavo prof. habil. dr. Jurgis Vanagas (1974, 1980, 1992, 1996).

Didieji pasaulio miestai, tikètina, dèl spartesnių ir intensyvesnių industrinių procesų su ekologinèmis problemomis susidūrè seniai, ir jau praejusio amžiaus pradžioje randama specialistų raginimų vykdyti miestų ekologijos tyrimus. McDonnell et al. (2009) nurodo, kad yra darbu, publikuotu XX a. ketvirtame dešimtmetyje, pavyzdžiui, $1935 \mathrm{~m}$. C. C. Adams darbas apie bendrosios ekologijos ryši su žmonių ekologija (The relation of general ecology to human ecology) arba $1938 \mathrm{~m}$. to paties autoriaus pastebejimai ekologijos specialistams, savo tyrimuose atsižvelgiantiems į visuomenini aspektą, bei geografams (A note 
for social-minded ecologists and geographers). Vykdyti tyrimai, atlikti darbai, konferencijos miesto ekologijos tematika buvo labai negausūs, vyko labiau dèl pavienių specialistų iniciatyvos nei dèl sistemingos mokslo šakos plètotès. Be abejo, didelę neigiamą ịtaką padarè II pasaulinis karas, daugumoje valstybių sutrikdęs ar net nutraukęs mokslinę veiklą. Natūralu, kad ankstyvieji darbai (XX a. pr. - XX a. vid.) nesulaukè didesnio visuomenès dėmesio: trūko žinių, mokslininkų tarpusavio bendravimo, be to, leidinių tiražas buvo ribotas, o priejimas prie jų komplikuotas.

Europoje, Azijoje, Australijoje ir Amerikoje susidomejjimas miesto ekologija ir su ja susiję tyrimai atsigavo maždaug prieš 30 metų: miestų ekologijos tyrimų medžiaga aktyviau publikuojama nuo 8-ojo - 9-ojo dešimtmečių (Davis 1976; Kahalas and Groves 1978; Kalma et al. 1978; Hengeveld and De Vocht 1982; Rapoport 1983). Pastaraji dešimtmeti publikacijų ir mokslinių darbų ypač pagausejjo. Tikètina, jog ekologijos mokslo populiarumui ženklią ịtaką padare 9-ajame dešimtmetyje gimusi darnumo koncepcija, kuri palaipsniui įsigalejo visame pasaulyje, drauge ir oficialioje politikoje (detaliau žiūr. 2.1 poskyrị). Garsiosios Jungtinių Tautų aplinkos ir vystymo konferencijos metu 1992 m. Rio de Žaneire (dar žinoma kaip Rio konferencija) buvo priimtas veiksmų planas „Darbotvarkè 21 “. Plano 40 skyriuje valstybès, tarptautinès, vyriausybinès ir nevyriausybinès organizacijos buvo raginamos sukurti indikatorius, kurie sprendimus priimančioms institucijoms pasitarnautu kaip darnaus vystymosi pagrindas (Agenda $21 \quad 2013 \mathrm{a}$ ). „Darbotvarkè 21“ korektiškai nurodè, kad „,siekiant subalansuotos plètros kiekvienas žmogus yra informacijos plačiaja prasme vartotojas ir teikejjas“ (Agenda 21 2013a).

Raginimas neliko neišgirstas ir palaipsniui augantis populiarumas kartu su intensyvia mokslo ir žinių plètra suponavo tam tikrą situaciją, kurią taikliai apibūdino Z. Baumanas: „Madingiems žodžiams lyg ir būdinga ta pati lemtis: juo daugiau patirties stengiamasi jais nuskaidrinti, juo labiau jie patys tampa miglotesni“ (Bauman 2007). Ši „,minkštą“ ir aptakų sociologinį pastebejjimą, kuris disertacijos rašymo metu ypač aktualus ir taikytinas darnaus vystymosi sampratai (neatsiejamai ir miestų ekologijai), jau kuris laikas fiksuoja ir technikos mokslai. Darnų vystymąsi ir / arba jo komponentus įvertinančių metodu yra sukurta ir praktikoje naudojama tiek daug ir ịvairių, kad pastaruoju metu pradèti publikuoti moksliniai straipsniai vien tam, kad įvertintu žinomus metodus. Pačiu metodų pakartotinis ịvertinimas, pertikrinimas ar perskaičiavimas traktuojamas kaip mokslinis darbas. Dalyje tyrimų apsiribojama vienaženkliu vertinimo metodų skaičiumi: Sharifi and Murayama (2013) atrinko septynis (LEED-ND, ECC, BREEAM Communities, CASBEE-UD, HQE ${ }^{2}$, Ecocity, SCR) populiarius kaimynijos darnumo vertinimo metodus iš Australijos, Europos, Japonijos bei Jungtinių Amerikos Valstijų ir juos palygino 
tarpusavyje. Kiti tyrimai platesni, apimantys dviženklius vertinimo metodų skaičius: Böhringer and Jochem (2007) analizavo vienuolika, Mori and Christodoulou (2012) - keturiolika, o Singh et al. (2009, 2012) - 41 darnumo indeksą, kai kurie iš jų, pavyzdžiui, gerovès indeksas (Well Being Index) turèjo 87 subindikatorius. Lietuvoje susikloste užsienio tyrimų praktikai analogiška metodika: dažniausiai analizuojamas ir vertinamas didelis indikatoriu, rodikliu ir / arba indeksų skaičius (Šaparauskas 2004; Ginevičius and Podvezko 2007; Zavadskas et al. 2007a, 2007b; Medineckienè et al. 2010; Kaklauskas et al. 2010; Alchimovienė 2012). Nepaliaujamai gausèjančią informacijos laviną gerai iliustruoja faktas, kad darnumo indikatorių (visumos ar atskirų komponentų) aptarimai, ivvertinimai, metodikos, kritika ir siūlomi patobulinimai dažnai nebeišsitenka straipsnių rèmuose ir pareikalauja atskirų knygų. Šiuolaikinių mokslo knygų apimtis dažnai siekia 300-500 puslapių (Lawn 2006; George and Kirkpatrick 2007; Hák et al. 2007).

Spartejjančio ir intensyvejjančio mokslinès informacijos srauto tendencija jaučiama ir politiniuose, su miestų valdymų plačiąa prasme susijusiuose dokumentuose. Rengiamos ataskaitos, studijos, monitoringo rezultatų aptarimai, specifinių parametrų analizės, tam tikrų projektų rèmuose renkamos ekspertų grupès, kurios savo ruožtu paskelbia tolesnes rekomendacijas, patarimus ir pan. (Salminen and Joas 2002; Lloyd-Jones 2004; The Cities Alliance 2007).

Daugumoje minètų darbų dažniausiai konstatuojamas tas pats faktas: indikatoriai yra galinga ir naudinga darnumo (jos komponentų) matavimo priemonè, tačiau esami matavimo būdai vis dar neaprejpia visų reikalingų sričių ir, siekiant aiškesnio ịvertinimo, rodiklius reikia toliau plètoti. Siūloma ịtraukti vis kitu parametrų ir / arba skaičiuoti nebe kažkuri vieną, o bent kelis indeksus, be to, kuriami apskritai nauji matavimo indeksai (Mayer 2008; Niccolucci et al. 2012; Dahl 2012; Mori and Christodoulou 2012).

Žinant praktines išeities priežastis, dabartinè situacija atrodo paradoksaliai. Nuolatinès esamų matavimų modifikacijos ir naujų paieškos tampa panašios i ekonominius procesus, kai idealusis tikslas yra nuolatos auganti rinka, kuri yra nevaržoma ir neturi pletros ribų. Toks mokslinès informacijos augimas tampa savitikslis, neturintis ryšio su realiai vykstančiai procesais. Informacijos, kad ir kokia nauja (patobulinta) ji būtų, nebeįmanoma pritaikyti praktikoje, ji vis labiau tolsta nuo pradinio - praktinio - tikslo. Problemą didina tai, kad galutinis rezultatas ypač priklauso nuo pasirinktos (sukurtos) skaičiavimo metodikos (Morse 2004). Pasauliniu lygmeniu duomenis renka tik kelios tarptautinès organizacijos ir daugumai rodiklių nustatyti naudojami tie patys išeities duomenys (Mayer 2008), tačiau rezultatai gali būti skirtingi ar net priešingi. Pasirinkus tam tikrus parametrus, galima gauti geresnius / blogesnius rezultatus nei kitu atveju (Morse and Fraser 2005; Morse 2006; Siche et al. 2008, 
Staniūnas et al. 2010) ir, nors forma atrodo patikima matematiškai, vis dèlto tinkamo sprendimo pasirinkimas tampa ypač komplikuotas.

Darbo ịvade deklaruotas praktinis darbo aspektas, t. y. galimybė darbo rezultatus pritaikyti miestų planavimo praktikoje (rengiant bendruosius planus). Darbe pripažistami sunkumai, su kuriais tenka susidurti realius sprendimus priimančioms, vykdančioms ir rezultatus prižiūrinčioms (atliekančioms monitoringa) organizacijoms, institucijoms ir kitiems praktikams, todèl darbe nepritariama savitikslei informacijos didinimo tendencijai. Praktiku pozicija aiškiai atsispindi Ekonominio bendradarbiavimo ir plètros organizacijos (OECD) išsakytame siekyje mažinti (arba bent grupuoti) rodiklių skaičių, atrenkant ir viešinant tik esminius ir pačius aktualiausius (OECD 2008). Šia kertinių parametrų atrinkimo - kryptimi buvo vadovautasi rašant darbą.

Esamų rodiklių gausa apsunkina jų panaudojimą planavimo praktikoje dèl dviejų priežasčių. Pirmoji labiau techninè: praktinèms užduotims igyvendinti skiriamas fiksuotas laikas, todèl visų imanomų (publikuotų) parametrų lyginimas ir ieškojimas tinkamesnio tampa nerealus. Be to, specialistas verčiamas spręsti ne tiesioginius savo srities klausimus, kuriuos išmano geriausiai, bet persikvalifikuoti i statistinių duomenų apdorojimo ekspertą. Antroji problema susijusi su OECD pastebejjimu: jei vertinami ne visi parametrai, būtina atrinkti kertinius rodiklius, tačiau kaip nustatyti, kurie yra svarbiausi?

Agreguotų darnumo indikatorių gausèjimas, tiesiogiai susijęs su darnos komponentus apibūdinančių parametrų augimu. Dažniau tyrimai atliekami ir daugiau demesio sulaukia ekonominis bei socialinis darnumo komponentai, o ekologinis aspektas lieka šiek tiek nuošalèje (UN 2011a), tačiau tai nereiškia, kad ekologinių tyrimų kiekị būtų galima ịvardinti kaip mažą ar lengvai apdorojamą: ekologinių indikatorių analizès vertos atskirų mokslinių straipsnių (Bandeira et al. 2013; Brukas et al. 2013). Tyrimai atliekami ivvairiu masteliu, pradedant išsamiais mažesnių ekologinių procesų tyrimais (Baltrenas et al. 2012) ir baigiant didelėmis analizuojamomis teritorijomis (Moore et al. 2013). Šiuo požiūriu tiek užsienyje, tiek Lietuvoje vykdomi ekologiniai tyrimai yra panašūs. Baldauf et al. (2013) publikuotame straipsnyje apie oro kokybę šalia greitkelių analizuoti šiuolaikiniam miestui svarbūs komponentai: transportas, susisiekimo infrastruktūra ir specifinès ekologinès pasekmès - oro užterštumas. Marinoni et al. (2013) pristatè metodą, kaip sumažinti neigiamą poveikị vandens kokybei, plečiant miestus, Paožalytė et al. (2012) tyrè triukšmo sklaidą Klaipėdoje dèl geležinkelio. Akivaizdu, kad tyrimai yra prasmingi konkrečios mokslo šakos apimtyje, tolimesnei jos plètotei ir pan., tačiau kaip elgtis realiose situacijose, kaip priimti tinkamą sprendimą praktikui? Vertinant iš miestų planuotojų perspektyvos, tampa sunku, tiksliau, neįmanoma nuspręsti, kuris rodiklis yra iš tikrujų svarbus ir kaip juos būtų galima taikyti planuojant. 
Ekologiniu procesų tyrimai bendraja prasme vyksta laisvai, t. y. mokslininkai gali rinktis, ką, kaip ir kada tirti, o miestu planavimas neatsiejamas nuo fiksuotu teisinių normų, reglamentai leidžia tam tikrą planavimo laisvumą, tačiau jis nè iš tolo negali būti lyginamas su mokslinių tyrimų laisvumu.

Ekologijos mokslo (ko gero, kaip ir kitų mokslo šakų) žinių taikymo planuojant galimybes apsunkina mokslo visuomenès susiskaldymas. Situacijos problemiškumą aiškiai apibrèžè Alberti et al. (2003) pastebejdama, kad „mokslininkai dažnai nesutaria dèl aplinkos pokyčių priežasčių, todèl politikos formuotojams tenka dirbti mokslinio neapibrèžtumo sąlygomis“. Mokslinis dialogas yra normali ir būtina mokslo vystymosi sąlyga, tačiau užsienyje, kalbant apie ekologiją ir miestų planavimą, be sąlyginai smulkmeniškų nesutarimų, ženklių diskusijų (Hahs et al. 2009) sukèlè prieš daugiau kaip dešimtmeti Grimm et al. (2000) publikuotas straipsnis. Autoriai diskutavo žmonių suvokimo, itakos miestų gyvenime tema, analizavo žmonių santykį su miesto aplinka ir išskyrè dvi ekologijos atmainas miestų aplinkoje: ekologiją miestuose ir miesto ekologiją.

Tyrejams iškilusių klausimų suvokimui naudinga trumpa ekologijos mokslo apžvalga. Wittig (2009) rašo, kad ekologijos terminas pirmą kartą buvo įvestas $1870 \mathrm{~m}$. ir nuo to laiko jo suvokimas stipriai evoliucionavo nuo grynai biologinio iki tarpdisciplininio mokslo, palaipsniui itraukiant tiek gamtos, tiek ir ne gamtos mokslus. Niemelä et al. (2009), remdamasis Haila ir Levins, nurodo, kad šiuo metu galimi keturi skirtingi termino traktavimai: 1) ekologija, kuri nagrinèja gamtos „ekonomikąa“, pavyzdžiui, medžiagų ir energijos srautus, 2) ekologija, kuri traktuoja aplinką kaip žmonėms skirtu išteklių visumą, 3) ekologija, kuri tiria žmonių ryšị su juos supančia aplinka, ir 4) ekologija, kuri siejama su politiniais, administraciniais veiksmais ekologinemis ir aplinkos temomis, pavyzdžiui, žaliujų judejjimas. Grimm et al. (2000) publikuotame straipsnyje miestams buvo suteiktas ypatingas dèmesys dèl iš principo paprastos priežasties: čia gyvena daugiausiai žmonių dèl ko atitinkamai sukeliamas didžiausias poveikis gamtai, tačiau klasikinès ekologijos tyrimų kontekste žmonès tiriami atskirai, izoliuotai nuo ekosistemų (Pickett et al. 2009). Tiriama, kaip ekosistemų procesai miestuose skiriasi nuo procesų ne miestuose, kaip miestų aplinka veikia organizmus, lyginant su užmiesčiu, kaip skiriasi oro užterštumas, pokyčiai vandenyje, grunte ir pan., t. y. tiriama, ką ir kaip paveikia žmonès, juos pačius suvokiant kaip tam tikrą jègą, trikdị, esanti šalia. Mokslininkams pasirodè nelogiška vertinti ekologinius procesus dirbtinai atsiejant pagrindinę pokyčių priežastị, varomają jègą (o ne trikdị) nuo gaunamų rezultatų. Išankstinis žmonių faktoriaus atskyrimas fragmentuoja mokslą, riboja ekosistemų procesų suvokimą ir - svarbu - neleidžia susidaryti pilno ekologinio miesto aplinkos vaizdo. Minètus klasikinius ekologinius tyrimus, susijusius su miestais, autoriai pasiūle suvokti kaip ekologiją miestuose, o tyrimus, kuriuose 
žmonès traktuojami kaip neatskiriama sisteminė dalis - miesto ekologija. Tai panašu i Vitousek et al. (1997) pasiūlytą terminą, „žmonių dominantès ekosistema“. Po kelerių metu Alberti et al. (2003) taikliai nurodè, jog žmonès veikia ekosistemos procesus tiek tiesiogiai, tiek netiesiogiai, tačiau ilgainiui šių pokyčiu padariniai atsisuka prieš tuos pačius žmones, todèl susidaro uždaras, nedalomas ciklas.

Pasiūlytas ekologijos terminų skirstymas įsitvirtino (Niemelä et al. 2009; Pickett et al. 2009; Hochuli et al. 2009), tačiau didžioji dabartinio ekologijos sampratos suvokimo, sietino su miestu aplinka, dalis priklauso ,ekologija miestuose" krypčiai, be to, miesto ekologijos tyrimų vis dar vykdoma sąlyginai nedaug (Hahs et al. 2009; McDonnell et al. 2009). Analogiška ekologinių tyrimų situacija susiformavusi ir su Lietuvoje: dažniausiai tyrimuose analizuojamas (klasikinis) žmogaus poveikis aplinkai (Laurinavičius et al. 2010; Bradulienè and Vasarevičius 2012; Vaiškūnaitè et al. 2012; Baziene et al. 2013).

Reziumuojant aptartą informaciją, galima pažymèti kelis esminius momentus. Ekologija, būdama darnaus vystymosi koncepcijos dalis, yra sulaukusi didelio specialistų dèmesio ir ateityje jai skiriamas dèmesys turètų didèti, nes šiuo metu ji vis dar atsilieka nuo ekonominio ir socialinio darnaus vystymosi koncepcijos komponentų. Augančio populiarumo neigiama pasekmé - informacijos gausa, kuri, nors ir naudinga mokslui, tačiau sunkiai pritaikoma praktikoje. Pastaruoju metu, ivertinus urbanizacijos tempus ir mastą, suvokta, kad žmonių veikla yra pagrindinè varomoji jèga, lemianti ekologinius procesus (pokyčius) miestuose, o tuo pačiu ir pasauliniu lygiu. Be to, siekiant visapusiškos ekologinès miestų aplinkos vaizdo analizès, žmonių veikla turi būti vertinama kaip neatskiriama (ir esminè) miesto ekologijos dalis. Tiek užsienyje, tiek Lietuvoje didžioji dalis ekologinių žinių sukaupta remiantis klasikine ekologijos mokslo samprata, todèl pripažįstama, kad miesto ekologijos plètojimas būtinas šiuolaikinèmis sąlygomis. Miesto ekologijos integravimas ị miestų planavimo procesą būtų naudingas postūmis, sudarantis sąlygas įžvelgti sąsajas tarp pagrindinès žmonių gyvenamosios vietos ir pagrindinès ekologinių procesu pokyčiu priežasties - pačių žmonių veiklos. Atsižvelgiant i privalomą juridini teritoriju planavimo aspektą, darbe toliau aptariami teisiniai klausimai, ieškant galimybių planavimo reglamentus susieti su miesto ekologija.

\subsection{Miestu planavimo reglamentavimas Europos Sajungos teisèje}

ES piliečių būdingiausia gyvenimo vieta - miestas, apie 350 milijonų žmonių gyvena urbanizuotose teritorijose, didesnèse negu 5000 gyventojų (EC 2011). Miestai dažnai apibūdinami kaip vietos, kuriose slypi daugiausia saviraiškos 
galimybių, didžiausios ekonominès plètros perspektyvos, generuojamos novatoriškos idejos, siūlomas plačiausias paslaugų spektras, patentuojamos mokslo ir pramonès naujovès. Vertinant iš istorinès perspektyvos, situacija jau daugeli metų išlieka tokia pati: dažniausiai kūrybingos ir aktyvios asmenybės palikdavo kaimus ir migruodavo ị miestus (Kirkeby and Meilstrup 2012). Tuo pat metu tuose pačiuose miestuose nuolatos susiduriama su rimčiausiomis problemomis: nepateisinti gyventojų / atvykèlių lūkesčiai, auganti socialinè poliarizacija ir segregacija, miesto ekosistemu ,apkrovimas“, saugumo neužtikrinimas, netinkamos gyvenimo darbo sąlygos ir pan. Dvipusę miesto struktūrą išsamiai apibūdino Leipcigo tvariujų Europos miestų chartija (2007):

„Mūsų miestai turi unikalių kultūros ir architektūros savybių, stiprią socialinès įtraukties jègą bei išskirtines ekonomikos vystymo galimybes. Jie yra žinių centrai bei augimo ir naujovių šaltiniai. Tačiau kartu jie patiria demografines problemas, socialinę nelygybę, tam tikrų gyventojų grupių socialinę atskirtị, prieinamo ir tinkamo būsto stoką bei aplinkos problemas. Ilgalaikejje perspektyvoje miestai nebegalès atlikti socialinès pažangos ir ekonomikos augimo variklio vaidmens, jeigu mums nepavyks išlaikyti socialinès pusiausvyros miestuose ir aplink juos, užtikrinant jų kultūros įvairovę ir nustatant aukštą miestų dizaino, architektūros ir aplinkos lygị.“

Akivaizdu, kad didžioji dalis europiečių vienaip ar kitaip yra susiję su miestais, todèl plačiaja prasme miestu visuminè kokybè yra svarbi visai ES: miestuose glūdi bendrijos ateitis. Bendri ES reikalai tvarkomi centralizuotai, yra sukurtas teisinis valdymo ir pavaldumo ryšių mechanizmas. Kontrolès mechanizmai skirti tik toms veiklos sritims, kurios laikomos svarbiomis visai bendrijos veiklai ir kurių veikimui būtina aukščiausio lygmens priežiūra, pavyzdžiui, žmonių teisès, darnus vystymasis, tarptautiniai santykiai ir pan. (ES 2013a). Europiniams tikslams igyvendinti buvo sukurtos specifinès valdymo priemonès - skirtingų paskirčių ir poveikio mastų (European Convention 2002).

Iki Lisabonos sutarties įsigaliojimo ES teisinè struktūra buvo trijų pakopų ir atskirą vietą užèmé tarptautinès sutartys (Hofmann 2011). Iš esmès ES funkcionavimas apibrezžtas ir reglamentuotas sutartimis (treaties), kurios yra pirminè, t. y. aukščiausia teisė ES ir Bendrijoje. Sutartyse, dèl kurių susitaria šalių narių vadovai, būna įtvirtinta oficialioji pozicija, jų pagrindu igyvendinami nustatyti politikos tikslai, be to, sutartyse apibrèžiamos kompetencijos sritys tarp ES ir šalių narių bei oficialios pagrindinès taisyklès, reglamentuojančios ES institucijų veiklą numatytose srityse (EC 2013a). Sutarčių veikimo principas specifinis: jos ịpareigoja ir igalina numatytas šalis (institucijas) veikti, tačiau istatymų leidžiamoji galia pačiose sutartyse nèra numatyta. Istatymų leidžiamoji galia perduodama institucijoms, kad jos galètu atlikti joms patikètus darbus, priimtieji teisès aktai laikomi antriniais (išvestiniais). Antriniai dokumentai turi būti suderinti ir atitikti pirminius, t. y. sutartis. Jei antriniuose dokumentuose, 
pavyzdžiui, yra nustatomi per platūs tikslai, kurie turi būti detalizuoti, atitinkamos institucijos gali išleisti papildomus paaiškinamuosius teisès aktus, kurie priskiriami paskutinei - trečiajai - pakopai. Tarptautiniai įsipareigojimai traktuojami kaip sekantys iš karto po pirminių teisès aktų, t. y. tarp pirminių ir antrinių dokumentų.

Lisabonos sutartis issigaliojo $2009 \mathrm{~m}$. gruodžio $1 \mathrm{~d}$. Oficialiai hierarchinė teisès aktų struktūra ir tarpusavio ryšiai buvo išlaikyti, nors specialistai juos apibūdina ne visiškai vienodai. Witte (2008) teigia, kad ES teisè sudaryta iš penkių kertinių elementų tokia tvarka: sutartys, nerašyti bendrieji principai, tarptautiniai susitarimai, privalomieji ES instituciju priimti tiesès aktai ir vadinamoji „minkšta“ teisè. Hofmann (2011) taip pat dalina ES teisę i penkias pakopas, tačiau nurodo kiek kitokią struktūrą: pirminè teisè, tarptautiniai susitarimai, istatymai, deleguotieji aktai ir igyvendinantys istatymai. Minètu atveju sutartys bei nerašyti bendrieji principai priskiriami aukščiausiai (pirminei) teisei, atitinkamai tarptautiniai susitarimai priskirti ne trečiai, o antrai (aukštesnei) pakopai.

Lisabonos sutartis pervadino pirmines sutartis (tai būdinga ES praktikoje) ir nors iš esmès išlaikè jų turini, buvo atliktos tam tikra korekcijos. Europos Sajungos sutarties ir Sutarties dèl Europos Sajungos veikimo suvestinès redakcijos 288 straipsnyje nurodyta, kad ,institucijos priima reglamentus, direktyvas, sprendimus, rekomendacijas ir nuomones“ (OL C 83 2010). Teisès aktai skirstomi i dvi dalis: turintys arba neturintys privalomosios galios. Privalomiesiems aktams priklauso reglamentai, direktyvos ir sprendimai, o neprivalomiesiems - rekomendacijos ir nuomonès (1.1 pav.). Privalomujų aktų struktūra nèra identiška: tarpusavyje jie skiriasi veikimo principais (European Convention 2002; ES 2013b). Reglamentai yra pačią griežčiausią galią turintys teisiniai ipareigojimai, kurie tampa privalomi be papildomų vietinès valdžios veiksmų, t. y. jie yra automatiškai privalomi visoms šalims narèms. Direktyvos, nors ir priklauso privalomiesiems aktams, veikia šiek tiek kitaip: jos netampa istatymu šalyse narèse, bet nurodo konkretų tikslą, Tinkamas priemones ir būdus, kaip tą tikslą pasiekti, vietos valdžia renkasi laisvai, todèl, pavyzdžiui, Lietuvoje priemonès gali būti skirtingos nuo taikomų, pavyzdžiui, Latvijoje. Sprendimas yra privalomas teisès aktas, tačiau ,sprendimas“ realiam gyvenime skiriasi nuo „sprendimo“ ES teisèje. Iš principo sprendimas taikomas tik tam, kam yra adresuotas, ir taikytinas tiesiogiai, tačiau po Lisabonos sutarties adresatas nebèra būtinas, tokiu būdu buvo praplèstos sprendimo taikymo galimybès (EC 2010b; ES 2013b). Nei rekomendacijos, nei nuomonès nèra privalomos, tai tiesiog galimybe institucijoms išreikšti poziciją teisiškai neįpareigojant (ES 2013b). 


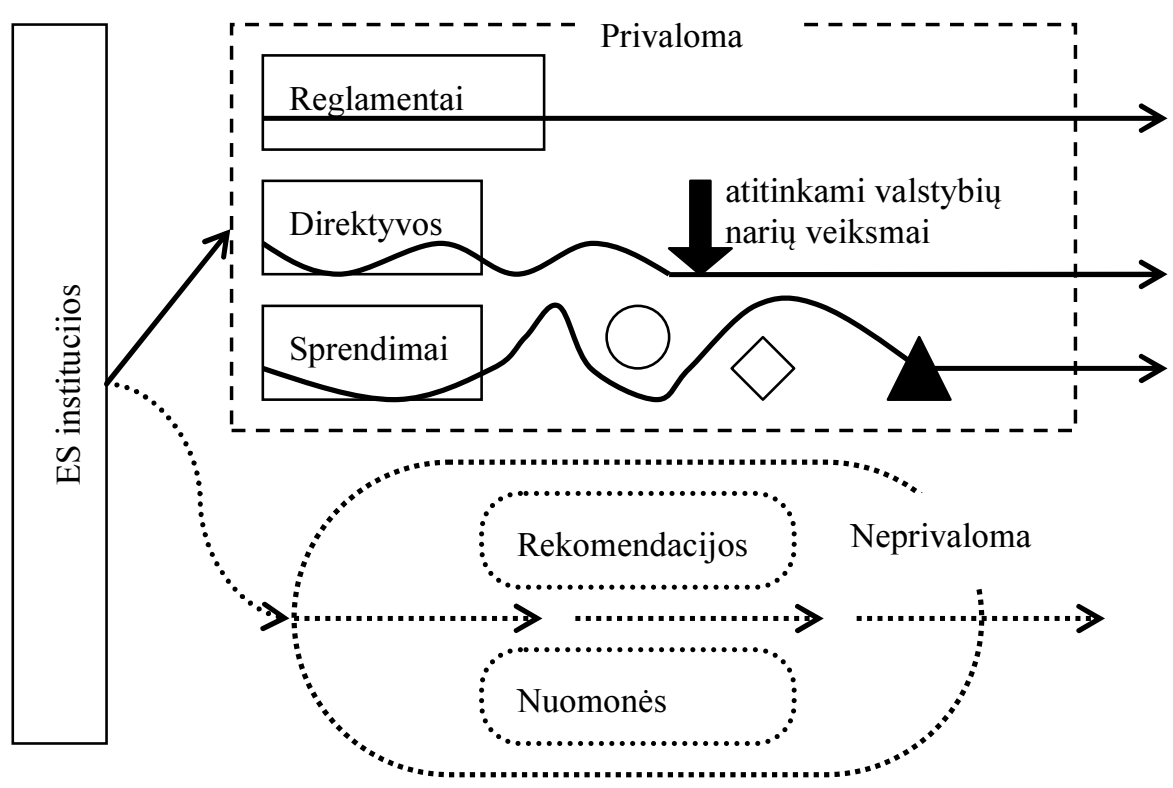

1.1 pav. Europos Sajungos teisès rūšys

Fig. 1.1. Types of European Union legal acts

Analizuojant ES teisès aktų rūšis iš miestų planavimo perspektyvos ir detaliau panagrinèjus pamatinius ES dokumentus, tenka pripažinti įdomų faktą. Realiame gyvenime miestai tampa vis svarbesni visos Europos lygmeniu, tačiau Mastrichto sutartyje (pasirašyta 1992 m., ,sukūre““ ES, susidedančią iš trijų kertinių komponentų, esminis tikslas - neapsiriboti vien tik ekonominiais tikslais, i pirmą planą iškeltos politinès ir socialinès idèjos. Vèliau sekè Amsterdamo (1997), Nicos (2001) ir Lisabonos sutartys (2007)) žodžio „miesto“ (urban) apskritai nèra. Taip yra todèl, kad miestu planavimas per se nèra Europos bendrosios politikos kompetencija (EC 2011).

Europos Sajungos sutarties ir Sutarties dèl Europos Sajungos veikimo suvestinès redakcijos 5 straipsnyje nurodyti trys pagrindiniai principai: suteikimo, subsidiarumo ir proporcingumo, nustatantys Sajungos kompetencijos ribas ir kompetencijos igyvendinimą (OL C 83 2010). Faktiškai skirstant veiklos barus (apibrèžiant kompetencijos ribas) tarp ES ir valstybių narių, pirmiausia vadovaujamasi suteikimo principu, juo remiantis ES turi teisę veikti tik ten, kur tai leidžia sutartys. Suteikimo principas yra pirminis ES veiklos principas, o likę $\mathrm{du}$ - subsidiarumo ir proporcingumo - jo vediniai, kurie tiksliau apibrěžia, kada, kokio masto ir kokios apimties veiksmų ES gali imtis. Sajungos dalyvavimas 
reikalingas srityse, kuriose valstybès narès pavieniui nèra pajègios sėkmingai veikti, todèl ES formuoja bendrą politiką tik ten, kur (EC 2010c; OL C 83 2010):

- veiksmai yra kompetencijos, suteiktos sutartyse valstybių narių, ribose (suteikimo principas);

- valstybės narès tikslų negali tinkamai pasiekti savarankiškai, o Sajungos lygiu juos pasiekti būtų geriau (subsidiarumo principas);

- Sajungos veiksmai savo turiniu ir forma neviršija to, kas būtina siekiant sutarčių (proporcingumo principas).

Apskritai ES politikos itaka bendrijos miestų planavimui yra menkai tyrinèta, ypač kai kalbama ne apie pavienius miestus ir iniciatyvas, o apie studijas, analizuojančias visą bendriją kaip visumą ir joje vykstančius bendrosios politikos pokyčius, turinčius ịtakos miestų planavimui. Tokio tipo analitinių darbų kol kas yra labai nedaug ir šiuo požiūriu ypač aktualūs ir vertingi yra EURICUR (European Institute for Comparative Urban Research) atlikti tyrimai: pirmasis publikuotas $1997 \mathrm{~m}$., antrasis po septyneriu metų - 2004. Pastarajame darbe (Berg et al. 2004) atskleistas ES politikos kitimas laikui bėgant ir yra išskirti penki etapai, susiję su reikšmingiausiais pokyčiais ES politikoje, turejusiais itakos (daugiausia netiesioginès) miestų planavimui. Pirmojo etapo $(1975$ - 1988 m.) laikotarpiu ES politikoje miestams nebuvo skiriama jokio dèmesio, bendroji politika iš esmés buvo nukreipta i didesnių vienetų - regionų - ekonominio disbalanso (turtingi - skurdūs regionai) mažinimą. Šiuo laikotarpiu, 1975 m., buvo ikurtas Europos regioninès plètros fondas (European Regional Development Fund (ERDF)), kurio tikslas dali bendrijos biudžeto perskirti neturtingiausiems regionams. Laikui bėgant, ERDF gaudavo vis didesnę ES biudžeto dalị. Antruoju laikotarpiu (1989-1993) Sąungoje buvo pripažinta, kad miestams yra skiriamas nepakankamas demesys ir $1991 \mathrm{~m}$. buvo pateiktas pasiūlymas pakeisti sutartis taip, kad miestų politikos formavimas taptu ES kompetencija. Pasiūlymas nebuvo realizuotas, nes valstybès narès tokios idejos nepalaikè. Svarbiu šio laikotarpiu pasiekimu laikomas miesto aplinkos pilotinių projektų (Urban Pilot Projects (UPP)) sukūrimas. Nors ES negalejjo tiesiogiai veikti miestu politikos, tačiau minètieji projektai (su aiškiu miestų aspektu) buvo vykdomi kaip regioninių skirtumų mažinimo projekai. Dél regionų planavimo politikos specifikos UPP buvo vykdomi su tam tikrais apribojimais, tačiau tai buvo akivaizdūs ES žingsniai miestų politikos link. Trečiuoju laikotarpiu (1994-1999) buvo reformuoti struktūriniai fondai (anksčiau vadinti solidarumo fondais) ir regionų politikos vykdymui buvo skirta trečdalis viso ES biudžeto. $1998 \mathrm{~m}$. urbanistinis forumas Vienoje atskleide, kad, skirtingai nuo $1991 \mathrm{~m}$., pasikeitè valstybių narių požiūris: jos buvo linkusios pritarti bendrai ES miestų politikai, atsirado bendros miestu politikos poreikis. $1994 \mathrm{~m}$. Europos Komisija pradejo programą (URBAN), skirtą urbanistinès regeneracijos ir sanglaudos klausimams spręsti, 
URBAN I tapo pirmaja programa, skirta išimtinai miestų problemoms, jai pritare valstybès narès. Ketvirtuoju laikotarpiu (2000-2006) buvo toliau stiprinama ekonominè sanglauda: struktūrinių fondų suma padidinta iki 35 \% ES biudžeto. Dalis struktūrinių fondų tiesiogiai arba netiesiogiai vis daugiau prisidedavo prie su miestais susijusių uždavinių sprendimo, tęsiant sèkmingą URBAN I programą, be URBAN II programos, pradèta URBCAT programa ir pilotinio projekto apie miestu auditą antroji fazè. Penktuoju laikotarpiu (2007-2013) miestams ir toliau igaunant daugiau svorio ir svarbos, valstybès narès skatinamos pačios skirti daugiau demesio miestų klausimams. Remiantis programų URBAN sèkme, Europos Komisija planuoja aktualizuoti miestams svarbius klausimus, ịtraukiant tam tikrus veiksmus i atitinkamas programas, tačiau reikia pažymèti, kad miestų politika ES lygiu taip ir lieka galutinai nelegalizuota.

Dèl aukščiau minètų teisinių ypatybių bendroji Europos miestų planavimo politika išlikusi sąlyginai laisva ir skirtinga, kalbant apie konkrečių veiksmų ir priemonių pasirinkimą, tačiau dažniausiai skirtingų miestų planavimo strategijas jungia panašūs tikslai. Taip atsitinka dèl to, kad miestuose kaip intensyviausiuose gyvenimo ir darbo taškuose, kertasi įvairūs interesai, kurie yra svarbūs visos Sajungos lygmeniu: pavyzdžiui, ekonominis, socialinis bendradarbiavimas, lygių teisių garantavimas ir pan. Stiprinant teritorinę sanglaudą ir siekiant visoms valstybėms narèms svarbių tikslų igyvendinimo, ES politiniai sprendimai vis dažniau netiesiogiai atsispindi ir miestuose, dažniausiai per (jau minètas) tam tikras programas ir finansuojamus projektus. Pastaruoju metu ES iniciatyvos, susijusios su miestais, plètojamas keturiuose srityse: „(i) ekonominès gerovès stiprinimas ir užimtumo didinimas miestuose ir miesteliuose; (ii) lygybès, socialinès ịtraukties ir regeneracijos skatinimas miestuose; (iii) miesto aplinkos saugojimas ir gerinimas siekiant vietos ir pasaulio tvarumo; ir (iv) geras miestų valdymas ir vietos valdžios galių didinimas" (EC 2011). Miestų svarbai tiek visai ES, tiek konkrečiai jos gyventojams ir toliau didejant, bendroji miestu politika tèra laiko klausimas: 2012 m. EMI (European Metropolitan Network Institute) paskelbè straipsni, kuriame paviešino apibendrintus urbanistikos ekspertu apklausos rezultatus. Remiantis surinktais duomenimis, urbanistinè politika turètų būti formuojama ES lygmeniu arba, kaip skambiai skelbė EMI antraštè, „Miestų politika absoliučiai privaloma ES lygmeniu“ (EMI 2012).

Apibendrinant atskleistą ES teisinę struktūrą ir pavaldumo ryšius iš šiandienos miestų planuotojų perspektyvos, tenka pripažinti faktą, kad (kol kas) ES teisès aktai tiesiogiai nereglamentuoja miestų planavimo politikos, taigi nèra ir galimybès surasti teisinio europinio miestų ekologijos išaiškinimo. Atlikta analizé fiksuoja kelis darbui svarbius momentus: 
- neegzistuojant ES urbanistinei politikai, miestų planavimas (taigi ir miestų ekologija) turètų būti apibrèžtas nacionalinio lygmens teisès aktuose;

- jei miestų ekologijos sampratos nacionalinio lygmens dokumentuose nebūtų, ją reikètų sukonstruoti ir pritaikyti planavimo poreikiams taip, kad būtų įtraukti visai Europai svarbūs aspektai;

- šiuo metu disertacijos tema yra ypač aktuali ir jos sprendiniai galètu prisidèti kuriant Europinę miestų ekologijos sampratą.

Tęsiant miesto ekologijos teisinio išaiškinimo paieškas, kita darbo dalis skirta LR teisinei bazei analizuoti.

\subsection{Pagrindinių Lietuvos Respublikos teritorijų planavimo dokumentų analizè}

Teritorijų planavimas yra reglamentuota teisinè procedūra, kurios metu formuojama teritorijos vystymo erdvinè koncepcija, gamybos ir infrastruktūros sistemos, nustatomos fizinių ir juridinių asmenų veiklos plètojimo teisès teritorijose, žemės panaudojimas, aplinkosaugos ir kitos sąlygos; teritorijų planavimą, planavimo dalyvių teises ir pareigas reglamentuoja Teritorijų planavimo istatymas ir poịstatyminiai aktai (AM 2006). Šioje darbo dalyje pristatoma Lietuvos teritoriju planavimo teisinè bazé, atskleidžiant teisès aktų hierarchinę struktūrą ir tarpusavio ryšius bei aptariant turinį. Teisinè bazè analizuojama vertinant tik tuos planavimo dokumentus, kurie susiję su miestų bendrujuç planų rengimu ir ieškant kiekybinių miesto ekologijos parametrų.

Šios darbo dalies tikslas - nustatyti, ar, vadovaujantis Lietuvos Respublikos planavimo norminiais dokumentais, egzistuoja miesto ekologijos išaiškinimas ir ar yra ịmanomas miesto ekologijos kiekybinis ịvertinimas. Atsižvelgiant i faktą, kad ekologija neatsiejama nuo darnaus vystymosi koncepcijos, analizę tikslinga papildyti Nacionaline darnaus vystymosi strategija (strategija nèra tiesiogiai susijusi su miestų bendraisiais planais). Taigi galutini informacini paketą sudarytų Nacionalinè darnaus vystymosi strategija, Teritorijų planavimo istatymas ir poįstatyminiai aktai.

Prieš analizuojant teisinès planavimo bazès turinį, naudinga glaustai apžvelgti teisès aktų hierarchiją, kuri grindžiama pavaldumo ryšiais (galia), t. y. žemesnejje struktūros vietoje esantis teisès aktas negali prieštarauti aukštesnejje vietoje esančiam teisès aktui (EK 2007). Lietuvoje hierarchine struktūra sudaryta iš 6 pakopų: Konstitucija, Konstituciniai ịstatymai, Seimo ratifikuotos tarptautinès sutartys, kodifikuoti įstatymai (kodeksai), paprastieji ịstatymai ir poịstatyminiai aktai (EK 2007). Reikia pabrèžti, kad Seimo ratifikuotos tarptautinès sutartys yra Lietuvos teisinès sistemos dalis ir jų vykdymas yra 
privalomas, o, išryškejjus neatitikimams tarp Lietuvos nacionalinio įstatymo ir tarptautinès sutarties, privaloma taikyti ne nacionalinę teisę, bet tarptautinę sutarti (EK, 2007). Kaip matyti iš pavaldumo ryšių, kalbant apie „Teritorijų planavimo įstatymą ir poịstatyminius aktus“, laikoma, kad Teritorijų planavimo istatymas yra pagrindinis planavimo teisès šaltinis, kurio pagrindu priimti poịstatyminiai aktai (pvz., Seimo ir / arba Vyriausybès nutarimai), ji (istatymą) sukonkretina.

Nacionalinè darnaus vystymosi strategija (toliau Strategija) yra patvirtinta Vyriausybès nutarimu, t. y. Strategija priklauso poịstatyminių aktų grupei, tačiau drauge Strategija yra glaudžiai susijusi su tarptautiniais ịsipareigojimais: patvirtinta vadovaujantis Europos Tarybos susitikimo rekomendacijomis ir Pasaulio valstybių ir vyriausybių vadovų susitikimo Johanesburge Igyvendinimo planu. Be to, Strategija yra kur kas platesnio profilio dokumentas nei Teritoriju planavimo istatymas, apimanti Lietuvos darnaus vystymosi strateginius prioritetus ir principus. Todèl nepaisant pavaldumo ryšių, planavimo teisinès bazès turinio analizè pradedama Strategija, po to analizuojamas Teritorijų planavimo ịstatymas, o poįstatyminiai aktai - pabaigoje.

Vyriausybė dar $2003 \mathrm{~m}$. patvirtino pirmają Nacionalinę darnaus vystymosi strategiją, kuri, atsižvelgus i ES reikalavimus, buvo pakeista (atnaujinta) 2009 $\mathrm{m}$. Strategijos 7 punktas apibrežia pagrindinius visos Lietuvos darnaus vystymosi siekius, iš kurių vienas tiesiogiai susijęs su ekologija: „, $<.>$ neviršyti ES leistinų normatyvų, laikytis tarptautinių konvencijų, ribojančių aplinkos taršą ir poveiki pasaulio klimatui, reikalavimų". Be to, Strategijoje suformuluoti darnaus vystymosi prioritetai ir principai, tikslai ir uždaviniai bei pateiktas nacionalinių darnaus vystymosi rodiklių sąrašas. Vadinasi, Strategijoje, galiojančioje nacionaliniu lygiu, yra dalis ekologiniu parametrų, kurie susiję su miestu planavimu, norint tuos duomenis įtraukti i miestų bendruju planų sprendinius, Strategijoje turi būti nurodyta, kokie tai rodikliai, ir kaip tuos rodiklius (tikslus) praktiškai igyvendinti.

Strategijos II skyrius nurodo net kelis darnaus vystymosi prioritetus, kurie galètų (taigi ir turètų) būti igyvendinti miestų bendruosiuose planuose, pavyzdžiui, pagrindinių ūkio šakų (transporto, energetikos, būsto ir kt.) poveikio aplinkai mažinimas arba ,daugiabučių namų modernizavimas ir šiluminės energijos sąnaudų būsto sektoriuje sumažinimas“, arba „pasaulinès klimato kaitos ir jos padarinių švelninimas, biologinès ịvairovès apsauga“. Teoriškai prioritetai aiškūs, tačiau praktikoje planuotojams iškyla sunkumų: nežinoma, kaip faktiškai minètus prioritetus ,perkelti“ $i$ bendruosius planus.

Strategijos V skyrius skirtas darnaus vystymosi tikslams ir uždaviniams, todèl keli atsitiktine tvarka iš skyriaus parinkti uždaviniai (sietini su miesto ekologija) pateikiami toliau: „užtikrinti, kad nebūtų viršijami aplinkos taršos normatyvai“, „saugoti ir gausinti želdynus ir kitas natūralias urbanizuoto 
kraštovaizdžio teritorijas“, „sumažinti tranzitinio transporto srautus per miestus ir ypač jų centrines dalis“, ,padidinti būstu energinį efektyvumą, spartinti daugiabučių namų modernizavimą". Seka atsitiktinè, tačiau joje galima pastebèti tą pačią pasikartojančią imperatyvią formą (užtikrinti, saugoti, sumažinti), Strategijoje tiesiog reikalaujama, užuot konkretizavus ir aiškinus, kaip išvardintus uždavinius igyvendinti. Be to, patys reikalavimai yra neapibrežti, pavyzdžiui, praktikoje gali kilti klausimas, ar tranzitinio transporto sumažinimas miestuose $12 \%$ yra pakankamas, o gal pakaktu $7 \%, 3 \%$...? Strategijoje atsakymo nèra, yra tik reikalavimas.

Strategija užbaigiama igyvendinimo priemonių planu, kuris, sprendžiant iš pavadinimo, galètų išsklaidyti išvardintas abejones ir konkretizuoti reikalingus veiksmus. Igyvendinimo priemonès surašytos atsižvelgiant $i$ atitinkamus uždavinius, todèl toliau atrinktos kai kurios aukščiau paminètų uždavinių priemonès:

- (uždavinys) „užtikrinti, kad nebūtų viršijami aplinkos taršos normatyvai" - (priemonè) ,plètoti visuomeninị transportą“;

- (uždavinys), ,saugoti ir gausinti želdynus ir kitas natūralias urbanizuoto kraštovaizdžio teritorijas“ - (priemonè) „parengti ir igyvendinti urbanizuoto kraštovaizdžio ekologines ir rekreacines funkcijas atliekančių natūralių ir subnatūralių teritorijų gausinimo ir tvarkymo projektus";

- (uždavinys) „sumažinti tranzitinio transporto srautus per miestus ir ypač jų centrines dalis“ - (priemonè), ,idiegti miestų transporto reguliavimo sistemas, sureguliuoti transporto srautus miestuose taip, kad jo būtu mažiau miestų centruose, sumažètų transporto spūstys, oro tarša ir triukšmas".

Tarpusavyje palyginta informacija aiškiai parodo, kad iš principo Strategijoje kartojama ta pati informacija, tiesiog skiriasi jos pateikimo būdas: siekiant sumažinti tranzitini transporto srautą, nurodoma sureguliuoti transporto srautus. Toks formulavimas eliminuoja veiksmo tikslingumą, nenurodo siektinos vertės ir - kas blogiausia - sudaro klaidinantị ịspūdị, kad - tikslą garantuoja pats veiksmo atlikimas, t. y. norint „užtikrinti“ pakanka „plètoti“.

Apibendrinant Strategiją galima apibūdinti dviem teiginiais: Strategija imperatyviai įtvirtina darnų (drauge ir ekologišką) vystymąsi nacionaliniu lygiu, bet kiekybiškai rodiklių neịvardina ir praktinio igyvendinimo veiksmų nekonkretizuoja.

Lietuvos Respublikos teritoriju planavimo įstatymas (toliau Teritoriju planavimo istatymas) yra kertinis dokumentas, reglamentuojantis teritoriju planavimą, planavimo procesą ir dalyvaujančių dalių teises bei pareigas. 3 straipsnyje apibrèžti aštuoni teritorijų planavimo tikslai, drauge darnus vystymasis, sveika aplinka ir kraštovaizdžio ekologinè pusiausvyra. Antroji 
straipsnio dalis nurodo, kad konkrečių teritorijų planavimo tikslai nustatomi atsižvelgiant $i \mathfrak{i}$ individualius, specifinius poreikius, pavyzdžiui, aplinkosaugos. 4 straipsnyje detalizuotos teritorijų planavimo trys rūšys (bendrasis, specialusis ir detalusis teritorijų planavimas), ir keturi lygmenys (nacionalinis, regiono, rajono ir vietovess). Lygmenys nustatomi pagal planuojamos teritorijos dydi ir sprendinių detalumą. Teritorijų planavimo įstatyme aiškinamos visos minètos planavimo rūšys, tačiau darbo temai aktualus tik bendrasis teritorijų planavimas. Šiai planavimo rūšiai yra skirtas atskiras skirsnis (antrasis), kuriame aprašyti bendrojo planavimo uždaviniai, dokumentai, planavimo procesas, tikrinimo ir tvirtinimo procedūros bei planavimo dokumentų igyvendinimas ir keitimo galimybès. 7 straipsnyje nurodyti planavimo uždaviniai pradedami tokiais žodžiais: „suformuoti $<$...> koncepciją“, ,optimizuoti < .. > struktūrą“, ,,numatyti priemones“, „nustatyti <..> zonas“ ir ,rezervuoti <..> teritorijas“. İdomu pastebėti, kad nors naudojama akivaizdžiai imperatyvi forma, įstatyme nèra atskleidžiama, kaip iškeltus uždavinius pasiekti, kitaip sakant, bendrojo plano rengejjai turi laisvą pasirinkimą, kaip, kokiu masteliu ir kokias priemones taikyti. Kita vertus, lieka neaišku, ar kokios nors priemonès bus apskritai taikomos. 10, 11 ir 12 straipsniuose didžiausias dèmesys skiriamas biurokratinèms planavimo procedūroms ir išlaikoma abstrakti liepiamoji pozicija, papildomai nedetalizuojama netgi aprašant sprendinių konkretizavimo stadiją (10 straipsnis).

Akivaizdu, kad, esant tokiai situacijai, Teritorijų planavimo įstatymo retorika tampa artimesnė apybraižai, planavimo gairių žymėjimui, tačiau ne aiškiai ir konstruktyviai teisinei kalbai. Problemą didina informacijos stoka: ne tik pačiame įstatyme vartojamos neinformatyvios frazès, bet ir nenurodoma, kur reikia ieškoti papildomos kiekybinès aiškinamosios medžiagos.

Miestų ir miestelių bendrųjų planų rengimo taisyklès (toliau Taisyklès) priklauso žemesnei teisés aktų hierarchinei pakopai nei Teritorijų planavimo istatymas, t. y. Taisyklès turi neprieštarauti įstatymui, be to, pavadinime esantis žodis „taisyklès“ nurodo, kad dokumentas per se turi būti konkretesnis. Viena iš teisès aktų hierarchizacijos priežasčiu yra tinkamo detalumo lygio parinkimas: detalizuojama, kol tampa aišku ir ịmanoma faktiškai pritaikyti. Taisyklèse nurodyta (1 punktas), kad jos skirtos miesto teritorijų bendrujų planų „rengimo, derinimo, tvirtinimo ir galiojimo" reglamentavimui, vadinasi, Taisyklèse turi būti detaliau aptarti planavimo rengimo etapo klausimai. Apskritai miesto bendrujų planų rengèjams suformuluoti devyni uždaviniai, susiję su teritorijų vystymu, tvarkymu ir apsauga, bendraisiais želdynais, inžinerinèmis komunikacijomis, gamtos išteklių saugojimu ir pan. Pažymèta, kad, esant konkretiems visuomenès poreikiams ar kitiems svarbiems ypatumams, galimi ir kiti uždaviniai. Taisyklèse nurodyti bendrojo plano uždaviniai atitinka Teritorijų planavimo įstatyme nustatytus uždavinius, t. y. išlaikytas teisinis vientisumas ir idejjinis tolygumas. Išlaikytas ir analogiškas uždavinių formulavimo principas (5 
punktas), jis toks pat tiesmukas ir imperatyvus: Taisyklèse nurodyta ,suformuoti $<\ldots>$ koncepciją“, „nustatyti <..> apsaugos prioritetus“, ,plètoti <...> infrastruktūrą", „numatyti priemones, užtikrinančias $<\ldots>$ ekologinę pusiausvyrą" ir pan. IV skyriuje išskirti keturi planavimo etapai: parengiamasis, planavimo dokumento rengimo, sprendinių pasekmių vertinimo ir baigiamasis, kurie vèliau aprašomi smulkiau. Darbui naudingiausias yra antrasis (rengimo) etapas, detalizuotas VI Taisykliu skyriuje. VI skyriuje pateikta daug medžiagos, pradedant bendrais nurodymais, kas turètų būti atliekama esamos būklès analizès metu, techniniais brěžinių atlikimo parametrais (pvz., brèžinių mastelis) ir baigiant išsamiu biurokratinių procedūru aprašymu. Neįsigilinus susidaro ịspūdis, kad rengimui reikalinga informacija yra aiškiai išdèstyta, tačiau, idèmiau paskaičius, susiduriama su tokia pačia neaiškia ir daugiaprasme retorika. VI skyriuje šiek tiek švelniau (turima omenyje rašymo stilius) nurodoma, kas yra „atliekama“ esamos būklès ar sprendinių konkretizavimo stadijoje, tačiau turinio prasme apsiribojama tokiomis pat aptakiomis frazemis kaip ir Teritorijų planavimo istatyme. Pavyzdžiui, apibrežta, kad sprendinių konkretizavimo stadijoje atliekamas „ekologinès apsaugos zonų plètojimas, biologinès ịvairovès apsaugos priemonių vystymas“, tačiau nèra paaiškinta, kas yra ekologinè apsaugos zona, jos plètojimo dydis ir pan. Kitaip sakant, iš esmès Taisyklèse kartojama ta pati turinio prasme neaiški, nekonkreti ir neartikuliuota informacija kaip ir Teritorijų planavimo istatyme. Taisyklès nesuteikia praktiškai naudingos informacijos miestų planuotojams, jos veikiau atlieka perteklinę, dubliuojančią biurokratinio dokumento funkciją.

Taisyklèse yra paminèti du planavimo metu privalomi atlikti vertinimai, kurie ypač sietini su disertacijos tema: planų ir programų strateginis pasekmių aplinkai vertinimas (toliau SPAV) ir bendrojo plano sprendinių poveikio vertinimas (toliau SPV). SPAV atsiradimas yra glaudžiai susijęs su tarptautine politika: Vyriausybès nutarime dèl SPAV patvirtinimo nurodomas Lietuvos ratifikuotas protokolas ir Europos Parlamento ir Tarybos direktyva, kuriais vadovaujantis ir buvo nutarta patvirtinti SPAV. O SPV teisinis pagrindas nacionalinis: dokumentas patvirtintas vadovaujantis Teritorijų planavimo ìstatymu. Abu dokumentai, nepaisant skirtingu išeities pozicijų, orientuoti i darnų teritorijų planavimą drauge poveikio aplinkai vertinimą. SPAV atliekamas koncepcijos rengimo stadijos pabaigoje, prieš priimant, tvirtinant arba renkantis tinkamiausią plano alternatyvą, o SPV vèliau - parengus konkrečius sprendinius, siekiant užtikrinti ,gerą priimamų sprendimų kokybę“. Abu vertinimai atliekami LR Vyriausybės nustatyta tvarka, t. y. jie yra juridinè, privaloma procedūra.

SPAV 5 punkte nurodyti trys vertinimo tikslai, iš kurių pirmasis yra skirtas „nustatyti, apibūdinti ir ịvertinti galimas $<\ldots>$ planų $<\ldots>$ igyvendinimo pasekmes aplinkai““. Atsižvelgiant i minètą Teritorijų planavimo ịstatymo ir Taisyklių neapibrěžtumą ir abstraktumą, SPAV turètų būti nurodyti pasekmių 
aplinkai vertinimo objektai, vertinimo priemonès, nustatyti kiekybiniai aplinkos rodikliai ir skaičiavimo metodika, tai yra būtina išeities sąlyga bet kokiam vertinimui. Tačiau iš tiesų SPAV nepateikia nè vieno techninio rodiklio: dokumentas iš esmès skirtas procedūriniams klausimams, proceso dalyviams ir jų funkcijoms aptarti, apimties nustatymo dokumentui, vertinimo ataskaitai rengti ir pan. Konkrečiausias minimas ekologinis parametras - ekologinis tinklas „Natura 2000“ - yra ne vietinès valdžios įdirbis, o Europos Bendrijos svarbos saugomų teritorijų tinklas.

SPV savo struktūra yra panašus ị SPAV - tekstinè aiškinamoji aprašo dalis ir du priedai. Vis dèlto, SPV atrodo techniškiau, ypač dèl priedų, iš kurių pirmasis yra penkių skilčių klausimynas, o antrasis - lentelè. SPV nurodyti sprendinių poveikio vertinimo principai ir aspektai (III dalis), du aspektai (7.1 ir 7.4) - vystymo darna ir poveikis gamtinei aplinkai - glaudžiai siejasi su disertacijos tema. Tačiau atidžiau pastudijavus dokumentą, konstatuotina ta pati techninio neapibréžtumo ir biurokratinių procedūrų aiškinimo tendencija. SPV neaiškina sąvokų, nepateikia vertinimo metodų, nenurodo siektinų verčių. Vertinant iš planuotojų pozicijos, SPV naudingumas toks pat kaip ir SPAV, praktikoje dokumentas nèra efektyvus. Atskirai verta pastebèti, kad 5 SPV punkte nurodyta, kad sprendinių poveikio vertintojai yra ,asmenys, rengiantys teritoriju planavimo dokumentus (planų rengejjai)“, t. y. tas pats asmuo rengia darbą, kuri vèliau pats vertina. Teisiškai ịtvirtinta situacija, kuri, priklausomai nuo aplinkybių, leidžia pateikti labai dviprasmiškus vertinimo rezultatus.

Be aukščiau minètų teisinių dokumentų, būtinų rengiant bendruosius planus, yra daug smulkesnių, specializuotų, tam tikroms sritims skirtų dokumentų. Jie turi sąsajų (dažniau netiesioginių) su miestų ekologija, tačiau dabartinès planavimo sistemos kontekste esminè problema yra planavimo laisvumas: planų rengèjai nèra vienareikšmiškai ipareigoti remtis konkrečiais teisès aktais, kiekvienas rengèjas tą pačią situaciją gali vertinti skirtingai, todèl ịvyksta fragmentacija.

LR teritoriju planavimo dokumentų aptarimą verta apibendrinti prisimenant miestų planavimo situaciją ES (1.2 poskyris): neegzistuojant vieningai ES urbanistinei politikai, miestu planavimas lieka reglamentuojamas nacionaliniu lygmeniu. Atsižvelgiant į ES deklaruojamą darnų vystymąsi, LR teisès aktuose formaliai itvirtinta darnaus vystymosi koncepcija, tačiau faktiškai esminis dèmesys nacionaliniuose teisès aktuose skiriamas procedūroms ir biurokratiniam veikimo mechanizmui išaiškinti. Dokumentams būdingas aprašomasis stilius, vartojamos abstrakčios ir daugiaprasmès frazès. Vertinant iš planuotoju perspektyvos, teisès aktuose trūksta konkretumo ir detalumo: miesto ekologijos sąvoka (kaip ir dauguma kitų sąvokų) nèra išaiškinta, pateikiama informacija nesisteminga, nenurodyti konkretūs kiekybiniai parametrai, leidžiantys ekologijos „kiekį“ apskaičiuoti ir palyginti. Faktiškai planavimo dokumentai 
(planai), parengti remiantis LR teritorijų planavimą norminančiais dokumentais, atitinka principinę ES kryptị savo forma, tačiau iš tikruju yra labai skirtingi savo turiniu, kuris nulemia, ar užkoduotas jame miesto valdymo modelis bus veiksmingas ar ne. Esant dabartinei situacijai, objektyvus miesto ekologijos vertinimas ir valdymas yra neįmanomas.

\subsection{Kiekybiniai parametrai Lietuvos Respublikos teritorijų planavimo dokumentuose}

Kalbant apie vertinimo galimybes, pradinis išeities taškas yra skaičiuotinosios vertès, t. y. prieš skaičiuojant reikia nustatyti, ką skaičiuoti. Šioje dalyje dar kartą analizuojami du teisès aktai (plačiau teritorijų planavimą Lietuvoje reglamentuojanti teisès aktų sistema buvo aptarta 1.3 poskyryje) - Teritorijų planavimo istatymas bei Miestų ir miestelių teritorijų bendrųų planų rengimo taisykless. Siais privalomaisiais dokumentais remiamasi rengiant bet kurio Lietuvos miesto bendraji planą. 1.3 poskyryje buvo atskleista, kad LR teisès aktams, reglamentuojantiems planavimą, ypač trūksta konkretumo ir aiškios rodiklių sistemos, todèl analizès tikslas - atrinkti Teritorijų planavimo įstatyme ir Taisyklèse ịvardintus kiekybinius parametrus, t. y. tokius parametrus, kurie turi arba gali ịgyti skaitinę vertę.

Lietuvos Respublikos teritorijų planavimo ịstatymo 2 straipsnis nurodo, kad „bendrasis planas - teritorijų kompleksinio planavimo dokumentas, kuriame, atsižvelgiant i teritorijų planavimo lygmenis ir uždavinius, nustatyta planuojamos teritorijos vystymo erdvinè koncepcija ir teritorijos naudojimo bei apsaugos principai“. Šią sąvoką dalinant $i$ atskirus segmentus, matyti keli joje užkoduoti teiginiai:

- bendrasis planas apima ivairias planavimo sritis (,kompleksinio planavimo dokumentas“), t. y. bendrasis planas rengiamas skirtingu sričių specialistų;

- bendrajame plane nustatomi parametrai gali būti skirtingo tikslumo, t. y. (dažniausiai praktikoje pasitaikantis variantas) didejjant planuojamos teritorijos plotui mažèjantis detalumo lygis, stambejjančios, vis daugiau apibendrinančios parametrų vertès;

- bendrajame plane nustatoma 1) erdviné koncepcija, 2) naudojimo principai ir 3) apsaugos principai, t. y. nustatomos tik svarbiausios tvarkymo priemonès.

Labai supaprastinus, galima teigti, kad bendrasis planas yra nevienalytis ir santykinai abstraktus dokumentas, todèl praktikoje bendrojo plano vertinimas dažniausiai yra probleminis. Šiuo atveju probleminiu įvardijamas ne kokybinis, bet kiekybinis vertinimas, kai bandoma vertinimams suteikti tikslią skaitinę 
vertę. Tame pačiame Teritorijų planavimo įstatyme yra apibrèžti ir nustatyti keli parametrai, kurie turi arba gali įgyti skaitinę išraišką. Minètieji parametrai yra:

- teritorijos naudojimo tipas - vadovaujantis teritorijų planavimo normomis, bendruosiuose, specialiuosiuose (masteliu 1:2000 ar stambesniu) ir (ar) detaliuosiuose planuose numatyta galima pagrindinè tikslinė žemès naudojimo paskirtis, galimi žemès naudojimo būdai ir, jei numatyta, pobūdis, maksimalūs užstatymo intensyvumo ir tankumo rodikliai ir galimų statyti statinių paskirtys;

- užstatymo aukštis - planuojamos teritorijos vyraujantis (daugiau kaip 70 procentų užstatymo) pastatų aukštų skaičius ar maksimalus pastatų aukštis metrais, kurio negalima viršyti;

- užstatymo intensyvumas - visų pastatų antžeminès dalies patalpų bendrojo ploto sumos santykis su žemès sklypo plotu;

- užstatymo tankumas - pastatais užstatomo ploto, nustatomo pagal sienu išorines ribas, santykis su visu žemès sklypo plotu;

- užstatymo tipas - teritorijų planavimo normose reglamentuota konkrečiai teritorijai būdinga ir galima pastatų išdèstymo zona ir erdvių išdèstymo struktūros ir parametrų visuma, nustatoma bendruosiuose, specialiuosiuose ir (ar) detaliuosiuose planuose.

Reikètų atskirai pabrèžti, kad, kaip matyti iš sąvokos išaiškinimo, teritorijos naudojimo tipas nurodo užstatymo intensyvumą ir užstatymo tankumą, nors praktikoje yra įprasta šiuos du dydžius drauge su užstatymo aukščiu pateikti atskirai, t. y. atskiriant nuo kitų teritorijos naudojimo tipą ịvardijančių parametrų. Nors tokios praktikos priežastys nèra galutinai aiškios, bet galima daryti prielaidą, kad šie parametrai yra ypač svarbūs realiame gyvenime, tad yra pateikiami atskirai. Vienas iš pagrindinių disertacijos siekių - realus pritaikymas, tuo remiantis darbe vadovaujamasi minètaja nusistovejusia praktika, t. y. užstatymo intensyvumas ir užstatymo tankumas traktuojami kaip atskiri parametrai.

Grį̌ztant prie vertinimo galimybių skaitinès išraiškos, visus išvardintus parametrus galima suskirstyti i dvi grupes: pirmajai grupei priklausytų parametrai, kurie turi tik skaitinę vertę, o antrajai daliai priklausytų parametrai, kurie gali ịgyti skaitinę išraišką atlikus papildomus skaičiavimus.

Atrinkti parametrus, priklausančius pirmajai grupei, yra paprasčiau (aiškiau), todèl būtų tikslinga pradèti nuo jos. Šiai grupei priklausytų užstatymo aukštis, užstatymo intensyvumas ir užstatymo tankumas. Užstatymo aukštis nurodomas vienetais (pastatų aukščių skaičius) arba metrais, o užstatymo intensyvumas ir užstatymo tankumas nurodomi dalimis arba procentais. Užstatymo tankumo vertè gali svyruoti nuo nulio (0\%) iki vieneto $(100 \%)$, bet vieneto (100 \%) negali viršyti. Maksimalus užstatymo tankumas (1 arba $100 \%$ ) pasiekiamas tada, kai užstatomas visas sklypas. Užstatymo intensyvumas - 
skirtingai nuo užstatymo tankumo - teoriškai neturi maksimalios vertès, t. y. yra neįmanoma užstatyti daugiau kaip viso sklypo, o pastato antžemine dalis gali būti labai aukšta, pavyzdžiui, aukštybinių pastatų, kai pastato aukštis siekia 20 arba 30 aukštų.

Teritoriju planavimo istatymas nepamini vieno skaitinio parametro, kuris vienaip ar kitaip figūruoja miestų bendruosiuose planuose: planuojant specialistai visada ịvertina prognozuojamą gyventojų skaičių. Planuotojai stengiasi atsižvelgti i tikètiną gyventojų skaičiaus kitimo dinamiką, tačiau dažniausiai Lietuvoje miestų bendrieji planai rengiami ir tvirtinami pagal optimistinius scenarijus, t. y. priimant prielaidą, kad gyventojų skaičius didès (iš tiesų Lietuvoje jau daugelị metų fiksuojama depopuliacija). Nesvarbu, koks scenarijus būtų priimamas, gyventojų skaičius yra svarbus skaitinis parametras, kurị būtina įvertinti, ir darbe šis parametras priskiriamas pirmajai grupei, kuri tokiu atveju išsiplečia iki 4 komponentų: užstatymo aukštis, užstatymo intensyvumas, užstatymo tankumas ir gyventojų skaičius.

Antrąą grupę sudarytų visi likę parametrai, t. y. teritorijos naudojimo tipas ir užstatymo tipas. Parametrai skaitinę vertę gali igyti tik po papildomų skaičiavimu, todèl, norint antrają grupę skaitmenizuoti, pirmiausia reikia atskirti parametrų sudedamąsias dalis. Remiantis sąvokų išaiškinimu, tokių dalių yra trys: pagrindinè tikslinè žemès naudojimo paskirtis, žemès naudojimo būdai ir erdvių išdèstymo struktūra. Teritorijos naudojimo tipas dar mini ,galimu statyti statinių paskirtis“, tačiau faktiškai statinių paskirtis yra apribojama žemės naudojimo paskirtimi (būdu), todèl darbe tai traktuojama kaip esminès ịtakos neturinti dalis. Atrinkus sudedamąsias dalis, galima jas konvertuoti i skaičius. Kalbant apie žemès naudojimo paskirtị ir būdus, kalbama apie tam tikro dydžio (ploto) teritorijos naudojimą, t. y. šios dalys yra neatsiejamos nuo ploto vienetų (kvadratinių metrų, arų ir kt.). Praktikoje žemės naudojimo paskirtis ir naudojimo būdai bendruosiuose planuose nurodomi grafiškai pažymint tam tikrą teritoriją su planuojama paskirtimi (būdu), todèl šios dalies duomenų skaitmeninè raiška (dažniausiai hektarai) tèra techninis klausimas. Priklausomai nuo programos, kuria braižomas bendrasis planas, gali reikèti suskaičiuoti atskirų tos pačios žemès paskirties (būdų) teritorijų plotų sumą, siekiant gauti galutini sumini rezultatą. Komplikuočiau būtų išreikšti skaičiais erdvių išdèstymo struktūrą, nes nèra aišku, ką tuo norima pasakyti (ịvardinti): erdvių tipą, dydị, formą, išsidèstymą ar pan. Vienareikšmiškai atsakyti i ši klausimą, remiantis vien teisès aktais, negalima, tačiau atsakymo galima ieškoti realioje planavimo praktikoje, kurios metu dažniausiai analizuojamas erdvių geografinis išdèstymas, t. y. atstumas tarp erdvių. Šiuo atžvilgiu atstumas gali būti suvokimas tiek ilgio vienetais (pvz., kilometrais), tiek laiko vienetais (pvz., minutėmis). Pastaruoju metu atstumo matavimas ilgio vienetais tampa vis mažiau reikšmingas, nes dažniausiai ịveikti kilometrai iš tikrųu neatspindi 
kelionejje sugaišto laiko, sunaudotos energijos ir tuo pačiu išmestų teršalų. Pavyzdžiui, rytinio piko metu kelionè iš Vilniaus pakraščių centro link (atstumas apie $7 \mathrm{~km}$ ) gali užtrukti tiek pat, kiek kelionè iš Vilniaus i Širvintas (atstumas apie $50 \mathrm{~km}$ ).

Teritorijų planavimo istatymas, net ir būdamas planavimo dokumentų hierarchijos viršuje, apibrèžia daugiausia kiekybinių parametrų lyginant su Miestų ir miestelių teritorijų bendrujų planų rengimo taisyklèmis. Jos betarpiškai susijusios su miestais ir miesteliais, tačiau yra labiau orientuotos ì procedūras, kurių detalūs aprašai sudaro didžiają jų dali. Pirmos grupès parametrų Taisyklèse iš viso nèra, o priskirtinų antrajai grupei irgi nedaug - tik du. Jie yra paminèti Taisyklių III skyriuje, kuriame nustatyti bendrojo plano uždaviniai, tiksliau, 5.3 punkte kalbama apie bendrojo naudojimo želdynus bei apsauginių želdynų sistemą. Taisyklès nenurodo, kokia tiksliai ši sistema turètų būti bei kokie galimi matavimo vienetai, taip pat lieka neaišku, kodèl bendrojo naudojimo želdynai neturi sudaryti sistemos. Remiantis planavimo praktika, želdynų dydis dažniausiai matuojamas ploto vienetais, todèl ir darbe siūloma bendrojo naudojimo želdinius ir apsauginius želdinius matuoti kvadratiniais metrais arba hektarais (analogiškai kaip žemes). Papildžius antrają grupę želdynais, ši grupé tampa sudaryta iš 5 komponentų: pagrindinè tikslinè žemès naudojimo paskirtis, žemès naudojimo būdai, erdvių geografinis išsidèstymas, bendrojo naudojimo želdynai ir apsauginiai želdynai.

Pirmoji ir antroji grupès sudarytos iš parametrų, kurie yra įvardinti Teritorijų planavimo įstatyme ir miestų ir miestelių teritorijų bendrujų planų rengimo taisyklèse (išskyrus gyventojų skaičių). Sujungiant kai kuriuos abiejų grupių parametrus ir atlikus nesudetingus skaičiavimus, galima gauti trečiąą grupę, t. y. abiejų grupių išvestinius (jungtinius) parametrus. Pirmajai grupei priklausantis užstatymo intensyvumas ir užstatymo tankumas, sujungti su žemès naudojimo būdu, parodytų, kiek ir kokios paskirties statiniu yra planuojama. Kitaip sakant, žemès naudojimo būdas nurodo, kokios paskirties statiniai gali būti statomi, užstatymo intensyvumas reglamentuoja tos paskirties statinių antžeminių dalių plotą, o užstatymo tankumas įvardija tos paskirties statinių užstatymų plotus. Be abejo, tokiu atveju kalbama apie maksimalius dydžius, t. y. išvestiniai parametrai parodytų didžiausius leistinus statinių plotus, kurie galètų atsirasti bendrojo plano sprendinių galiojimo laikotarpiu. Reikètų pabrèžti, kad nors gautos vertès būtų tikslios, tačiau daugiau teorinès: kaip jau buvo minèta, dažniausiai miestų bendrieji planai rengiami pasirinkus optimistinį scenarijų (numačius miestų plètrą), tačiau faktiškai Lietuvoje absoliuti dauguma miestų ir miestelių merdi, gyventojų skaičius mažeja, be to, 10 metų laikotarpiu gali atsitikti nenumatytų aplinkybių, pavyzdžiui, dar viena ekonominè krizé, kuri sustiprintų emigraciją. Todèl trečiosios grupès parametrus reikia įvertinti kaip vertes, kurios praktikoje nebūna viršijamos. 
1.1 lentelè. Miestų planavimo kiekybiniai parametrai

Table 1.1. Quantitative parameters of urban planning

\begin{tabular}{|c|c|c|c|c|c|}
\hline \multicolumn{3}{|c|}{ I grupè (turi skaitinę vertę) } & \multicolumn{3}{|c|}{ II grupè (gali igyti skaitinę vertę) } \\
\hline $\begin{array}{l}\text { Eil. } \\
\text { Nr. }\end{array}$ & Pavadinimas & $\begin{array}{l}\text { Matavimo } \\
\text { vienetas }\end{array}$ & $\begin{array}{l}\text { Eil. } \\
\text { Nr. }\end{array}$ & Pavadinimas & $\begin{array}{l}\text { Matavimo } \\
\text { vienetas }\end{array}$ \\
\hline I. 1 & $\begin{array}{l}\text { Užstatymo } \\
\text { auštis }\end{array}$ & $\begin{array}{l}\text { Aukštais arba } \\
\text { metrais }\end{array}$ & II.1 & $\begin{array}{l}\text { Pagrindinè } \\
\text { tikslinè žemès } \\
\text { naudojimo } \\
\text { paskirtis }\end{array}$ & $\begin{array}{l}\text { Ploto vienetais } \\
\text { (kvadratiniai } \\
\text { metrai, hektarai } \\
\text { ir pan.) }\end{array}$ \\
\hline $\mathrm{I} .2$ & $\begin{array}{l}\text { Užstatymo } \\
\text { intensyvu- } \\
\text { mas }\end{array}$ & $\begin{array}{l}\text { Vieneto } \\
\text { dalimis arba } \\
\text { procentais }\end{array}$ & II.2 & $\begin{array}{l}\text { Žemès } \\
\text { naudojimo } \\
\text { būdais }\end{array}$ & $\begin{array}{l}\text { Ploto vienetais } \\
\text { (kvadratiniai } \\
\text { metrai, hektarai } \\
\text { ir pan.) }\end{array}$ \\
\hline $\mathrm{I} .3$ & $\begin{array}{l}\text { Užstatymo } \\
\text { tankumas }\end{array}$ & $\begin{array}{l}\text { Vieneto } \\
\text { dalimis arba } \\
\text { procentais }\end{array}$ & II. 3 & $\begin{array}{l}\text { Erdvių } \\
\text { geografinis } \\
\text { išsidèstymas }\end{array}$ & $\begin{array}{l}\text { Atstumo arba } \\
\text { laiko vienetais } \\
\text { (metrai, } \\
\text { kilometrai arba } \\
\text { minutės, } \\
\text { valandos ir pan.) }\end{array}$ \\
\hline I.4 & $\begin{array}{l}\text { Gyventojuc } \\
\text { skaičius }\end{array}$ & Vienetais & II.4 & $\begin{array}{l}\text { Bendrojo } \\
\text { naudojimo } \\
\text { želdynai }\end{array}$ & $\begin{array}{l}\text { Ploto vienetais } \\
\text { (kvadratiniai } \\
\text { metrai, hektarai } \\
\text { ir pan.) }\end{array}$ \\
\hline & & & II. 5 & $\begin{array}{l}\text { Apsauginiai } \\
\text { želdynai }\end{array}$ & $\begin{array}{l}\text { Ploto vienetais } \\
\text { (kvadratiniai } \\
\text { metrai, hektarai } \\
\text { ir pan.) }\end{array}$ \\
\hline \multicolumn{6}{|c|}{ III grupė (jungtinis parametras) } \\
\hline $\begin{array}{l}\text { Eil. } \\
\text { Nr. }\end{array}$ & \multicolumn{2}{|l|}{ Pavadinimas } & \multicolumn{2}{|c|}{ Matavimo vienetas } & Pastabos \\
\hline III.1 & \multicolumn{2}{|c|}{$\begin{array}{l}\text { Maksimalus visų pastatų } \\
\text { antžeminès dalies patalpų } \\
\text { bendrasis plotas }\end{array}$} & \multicolumn{2}{|c|}{$\begin{array}{l}\text { Ploto vienetais } \\
\text { (kvadratiniai metrai, } \\
\text { hektarai ir pan.) }\end{array}$} & I. $2+$ II .2 \\
\hline III. 2 & \multicolumn{2}{|c|}{$\begin{array}{l}\text { Maksimalus visais pastatais } \\
\text { užstatomas plotas }\end{array}$} & \multicolumn{2}{|c|}{$\begin{array}{l}\text { Ploto vienetais } \\
\text { (kvadratiniai metrai, } \\
\text { hektarai ir pan.) }\end{array}$} & I. $3+$ II. 2 \\
\hline
\end{tabular}


Apibendrinant 1.4 poskyrị, skaitiniai parametrai, atrinkti iš Teritorijų planavimo įstatymo bei miestų ir miestelių teritorijų bendrujų planų rengimo taisyklių, pateikti 1.1 lentelèje.

\subsection{Pirmojo skyriaus išvados}

1. ES dalyvavimas šalių vidaus valdyme yra stipriai apribotas kertinių ES dokumentų ir intervencijos ,iš viršaus“ atvejis - daugiau išimtis nei rutiniškai atliekamas veiksmas. Pagrindinè pageidautina ES miestu planavimo politikos kryptis - darni plètra, tačiau miestu valdymo modelis iki šiol nèra pakankamai konkretizuotas ir vieningos europinès politikos miestų atžvilgiu nėra. Kol kas skatinama aktyvi vietos valdžios, kuri lieka pagrindiniu miestą formuojančiu žaidèju, veikla.

2. LR teritorijų planavimo teisès dokumentų analizès metu pastebimas vyraujantis darnios pletros (atitinkamai ES) naratyvas: darnaus vystymosi nuostata yra teigiamà ir tiesiogiai, ir netiesiogiai, t. y. teisès aktuose dažnai ittvirtinta bent viena darnaus vystymosi sudètinè dalis, todèl, vertinant bendrą vaizdą ir nesigilinant ì detales, darnios plètros požiūriu LR planavimo dokumentai atitinka ES pageidaujamą kryptį.

3. Problemos ryškejja detaliau paanalizavus, kas yra nuveikta vietos valdžios, kad miesto ekologija (darnaus vystymosi sudètinė dalis, analizuojama disertacijoje) igautų konkrečią krypti ir rodiklius. Nustatyta, kad teisès aktuose imperatyviai kartojamas darnios plètros siekimas, tačiau miestų planavimą reglamentuojančiuose dokumentuose remiamasi aptakiomis, nekonkrečiomis politinio tipo frazèmis, o miesto ekologijos termino ir / arba sudètinių dalių struktūros išaiškinimo teisès aktuose apskritai nèra.

4. Analizès metu buvo pastebètas planavimo teisinès bazès neapibrèžtumas ir didelis veiksmų laisvumas, tačiau teisès aktuose buvo rasti ir tam tikri skaitiniai rodikliai, sutinkami miestu bendruosiuose planuose. Rodikliai buvo surinkti iš svarbiausių planavimui teisès aktų ir suskirstyti ị tris pasiūlytas grupes: I grupei priskirti rodikliai, iš karto turintys skaitinę vertę; II grupei priskirti rodikliai, galintys igyti skaitinę vertę po papildomų veiksmų; III grupei priskirti (jungtiniai) rodikliai, gauti derinant tam tikrus I ir II grupès rodiklius. Iš viso klasifikuota vienuolika rodiklių: keturi pirmosios, penki antrosios ir du trečiosios grupès. 


\section{2}

\section{Miesto ekologijos modelis: struktūra ir ribos}

Pirmame skyriuje, remiantis atlikta mokslinès ir teisinès informacijos apžvalga, buvo konstatuota, kad vienalytès teisinès bazès, skirtos miestų ekologijai, nèra tiek europiniu, tiek ir Lietuvos nacionaliniu lygiu. Iš LR teisès aktų galima atrinkti kiekybinius (skaitinius) parametrus, tačiau nèra aišku, kokios jų siektinosios vertès ir kaip tas vertes praktikoje planavimo specialistas galètų užtikrinti. Be to, neegzistuojant vienareikšmei miesto ekologijos sampratai, neįmanoma nuspręsti, ar turimų skaitinių parametrų užtenka miesto ekologijai garantuoti, ar turimi skaitiniai parametrai yra būtent tie, kurių reikia. Logiškai mąstant vienintelis įmanomas kelias judèti tolyn - pasiūlyti miesto ekologijos modelio sampratą, kuri tiktų miestų planavimui. Šiuo konkrečiu atveju žodis „tiktų“ apima kelis uždavinius: miesto ekologijos modelis turi būti išgrynintas (apibrèžta) iki konkrečių pagrindinių veiklos sričių, šios sritys turi igauti kiekybinius parametrus, šias veiklos sritis turi būti įmanoma valdyti (planuoti) Lietuvos miestų bendrujų planų galimybiu ribose ir tuo pačiu miesto ekologija turi būti suvokiama platesniame kontekste. Platesnis kontekstas būtinas dèl ekologinių procesų prigimties, kurių nę̇manoma dirbtinai suvaržyti administracinėmis miesto ribomis (plačiau žiūr. 2.2 poskyrị apie išorinę ir vidinę ekologiją). Antrame skyriuje aptariamas esminis darnos (kaip junginio) ir ekologijos (kaip atskiro komponento) skirtumas, pristatomas miesto ekologijos 
modelis, sąlygos jo atsiradimui ir analizuojamas ekologinių ribų klausimas. Šio skyriaus tema publikuotas straipsnis (Staniūnas 2012).

\subsection{Miesto ekologijos procesu specifika}

Ekskursas - trumpa darnos sąvokos sampratos istorija. Pastaruoju metu darnos sąvoka ir jos vartojimas yra tapę tokia neatskiriama profesinio (planuotojų, architektu, politiku ir pan.) gyvenimo dalimi, galima pavadinti net profesine norma, jog susidaro įspūdis, kad terminas yra natūraliai evoliucionavęs ir gyvuoja visą amžių. Faktiškai darnumo koncepcijos ištakos tesiekia 1970-uosius metus ir pati istorija neịsivaizduojama be sąlyginai nesenos $(1945 \mathrm{~m}$.) organizacijos - Jungtinių Tautu - iniciatyvos. JT (UN 2011a) ir Jungtinių Amerikos Valstijų aplinkos apsaugos agentūra (U. S. EPA 2013) ịvardija iš principo vienodas darnos koncepcijos atsiradimo priežastis ir institucionalizacijos procesą. $1972 \mathrm{~m}$. ivykusi Stokholmo konferencija pademonstravo stiprejjantį industrializuotų ir besivystančių šalių dialogą dèl pasaulinio vystymosi įtakos aplinkai ir atkreipé dèmesį dèl visų žmonių teisès i sveiką aplinką. Po Stokholmo konferencijos ịvyko daug susitikimų panašia (žmogus - gamta - vystymasis) tematika, to rezultatas - organizacijų ir programų, atsakingų už minètus uždavinius, prie JT sukūrimas, drauge ir garsiosios UNEP (United Nations Environment Programme). Beveik po dešimtmečio (1980 m.) buvo publikuota Pasaulio išsaugojimo strategija (World Conservation Strategy (WCS)), kuri akcentavo, kad gamtos išsaugojimas neįmanomas be mažiau išsivysčiusių pasaulio regionų atsilikimo ir skurdo mažinimo, bei užfiksavo, kad vystymasis negali būti begalinis, nes yra ribojamas natūralių planetos galimybių. Laikoma, kad WCS ženkliai prisidejjo prie darnumo koncepcijos atsiradimo. $1983 \mathrm{~m}$. darnumo koncepcijos istorijoje atsiranda (ko gero) garsiausias vardas - Brundtland - turima omenyje Norvegijos premjerministre, kurios JT generalinis sekretorius paprašè vadovauti Pasaulinei aplinkos ir vystymo komisijai (World Commission on the Environment and Development (WCED), dar žinomai Brundtland Commission vardu). Komisijos uždaviniai buvo trys: ivertinti pasaulines aplinkos ir vystymosi problemas bei pateikti pasiūlymus, sustiprinti tarptautini bendradarbiavimą ir didinti organizacijų, verslo ir vyriausybių savivokos lygị. 1987 m. WCED darbą reziumavo publikuodama ataskaitą „Mūsų bendra ateitis“ (Our Common Future dar vadinamą The Brundtland Report), kuris suformulavo dabartini (tradicinį) darnos apibrèžimą, suvaidino lemiamą vaidmeni jo viešinime ir akcentavo, kad aplinka negali būti traktuojama kaip izoliuota nuo žmonių sfera, nesusijusi su jų veiksmais, ambicijomis ir poreikiais. $1992 \mathrm{~m}$. pasaulio lyderiai antrą kartą (20 metu po Stokholmo konferencijos) susirinko 
aptarti aplinkos ir vystymosi klausimų Rio de Žaneire, tai buvo pirmoji JT aplinkos ir vystymo konferencija (UN Conference on Environment and Development). Svarbiu laikomas faktas, jog dalyviams buvo sudaryta galimybė pasirašyti tarptautines konvencijas dèl klimato kaitos ir biologinès įvairovès tokiu būdu legitimuojant savo dalyvavimą darnaus vystymosi procesuose. Konferencijos metu priimta veiksmu programa „Darbotvarkè 21“ (Agenda 21) dar kartą patvirtino, jog darnų vystymąsi sudaro trys kertiniai - ekonomikos, socialinis ir aplinkos - komponentai. İdomu, kad 28 skyriuje (Agenda 21 2013b) teigiama, kad „savivaldybès formuoja, išlaiko ir naudoja ekonominę, socialinę bei aplinkos infrastruktūrą, numato ateities planus, rengia vietos aplinkosaugos strategiją ir nuostatas bei padeda igyvendinti nacionalinę ir regioninę aplinkosaugos politiką. Kaip arčiausiai visuomenès esančios valdymo institucijos, savivaldybès atlieka esmini vaidmeni lavinant, mobilizuojant ir reaguojant i visuomenę taip skatindamos subalansuotos plètrą“. Taigi akivaizdžios sąsajos su 1.2 poskyryje detaliau aprašytu ES subsidiarumo principu, kuris labai panašiai nustato, kad lemiamą vaidmeni planuojant turetų atlikti vietos valdžia. Vis dèlto Lietuvos praktika (1.3 poskyris) rodo, kad minètieji siekiai Lietuvoje (bent jau iš planuotoju perspektyvos) praktiškai dar nèra igyvendinti. 10 metu po Rio deklaracijos Johanesburge buvo surengta kita konferencija, kurios tikslas - atnaujinti dalyvių pasižadejjimus, vykdant darnią plètrą, konferencijoje nustatytos penkios prioritetinès veiklos kryptys: vanduo, energija, sveikata, žemès ūkis ir biologinè îvairovè. Darnaus vystymosi aktualumą ir koncepcijos palaikymą, ko gero, geriausiai atskleidžia konferencijoje dalyvavusių žmonių skaičius - apie 60 tūkstančių. Istorinị ekskursą užbaigia $2012 \mathrm{~m}$. JT konferencija, vadinama Rio+20. Jos metu spręstos dvi esmines darnaus vystymosi temos: ekologiška ekonomika darnaus vystymosi ir skurdo panaikinimo kontekste ir institucijų itaka darniam vystymuisi bei nustatytos septynios prioritetinès veiklos sritys: tinkamas darbas, energija, darnūs miestai, maisto saugumas ir darni žemdirbyste, vanduo, vandenynai ir pasiruošimas nelaimèms (UN 2011b). Tai pirmas kartas, kai miestų klausimai buvo ịtraukti ị oficialiają dienotvarkę, nurodant juos kaip vieną iš svarbiausių šių laikų prioritetų.

Ekskurse atsiskleidžia du svarbūs momentai. Pirma, paaiškèja sąlyginai jauno termino formavimosi etapai, spartus vartojimo intensyvejjimas ir iškilimas iki pasaulinio lygmens ideologijos. Viešai suformuluota $1987 \mathrm{~m}$. ir oficialiai institucionalizuota kaip būdvardis 1992 metais darnaus vystymosi ideja laikoma viena iš įtakingiausių XX a. pabaigos koncepcijų, turinčių išskirtini socialini bei politini svorị. Appleton (2006) jau prieš kelerius metus pastebejjo, kad tokių faktiškai nuo nulio iki per porą dešimtmečių visam pasauliui turinčių ịtakos idejjų ir procesų yra nedaug. Teigiama, kad darnumo idejją galima gretinti su pramonès konvejeriais, po II-ojo pasaulinio karo prasidejjusiais 
antikolonizaciniais procesais, kontraceptinèmis piliulemis ir interneto įsigalejjimu. White (2013) publikavo straipsnį, kuris skirtas šiuolaikinių technologijų (tag cloud) taikymui vizualizuojant darną, t. y. pabandyta ši labai populiarų terminą perkelti i kitą dimensiją - pamatyti. Antrasis momentas yra tam tikras pirmojo aspekto antipodas: pastebima, kad greta visuotinio ìsigalèjimo drauge darnos koncepcija yra paženklinta nuolatiniu nesėkmès ženklu, šiuo atveju turimas omeny ne trūkstamas pripažinimas (dauguma valstybiu yra įtraukusių darnų vystymąsi tiesiogiai ar netiesiogiai ị savo politines programas), o faktinis užsibrežto tikslo neigyvendinimas. Vienokias ar kitokias igyvendinimo spragas pastebi tiek ir JT, tiek ir kitos tarptautinès organizacijos ir liudija tarptautinès ataskaitos ir ịvertinimai (pvz., Millenium Ecosystem Assessment 2005). Aktualus disertacijai yra JT pastebejjimas, kad nors darnios plètros terminas įejo ị tarptautinį oficialų leksikoną daugiau kaip prieš 20 metų ir koncepcija pripažįstama daugelio valstybių bei pasaulinių organizacijų, pastarosios turi konstatuoti, kad faktiškai suteikti aplinkos (gamtos, ekologijos) komponentui toki patị svori kaip kitiems dviem yra be galo sunku (UN 2011a). Situacijos nekeičia ir faktas, kad mokslo visuomenè jau nuo $1960 \mathrm{~m}$. signalizuoja apie Žemès pažeidžiamumą.

Vertinant aptartos informacijos visumą, gaunamos prieštaringos išvados. Viena vertus, galima teigti, kad dabartine vyraujanti kryptis teisinga ir, nors trūksta priemonių, patirties igyvendinant ar konkretumo, tikslas vis vien bus pasiektas, tai paprasčiausiai laiko klausimas (tiesa, įdomu, kiek to laiko galima skirti?). Kita vertus, atsižvelgiant ì nuolatines nesėkmes, darnumo skleidèjus galima kaltinti utopijos propagavimu, nerealiais politiniais gundymais, kurių pagrindiné žinia tèra spekuliacija, teigianti, kad darniai elgiantis visi gali pretenduoti i savo dali ir vengti tikrų veiksmų (Appleton 2006). Nesiimant spręsti (tai nèra šio darbo tikslas), kur slypi tiesa ir kada darni plètra bus realiai igyvendinta visame pasaulyje, disertacijos temos plètotei naudingesné yra pirmoji išvada: turimas omenyje laikas, tačiau svarbus yra ne papildomas laikas ir kiek jo dar reikia, bet apskritai darnumo santykis su pačiu laiku arba konkrečiau laiko tęstinumu.

Suvokus ir pripažinus, kad darnumo dar nèra pasaulyje pasiekta, galima būtų daryti logišką išvadą, kad nei vienas iš komponentų nèra, o drauge ir (kol kas) negali būti visiškai ịgyvendinti. Kitaip sakant, disertacijos tikslas, susijęs su darnaus vystymosi dalimi, t. y. ekologiniu komponentu, taip pat atsidurtų sunkiai apibrežiamoje erdvejje, tačiau taip nèra dèl esminio skirtumo tarp darnos koncepcijos kaip nedalomo vienio ir jos atskirų sudedamujų dalių. Kalbant apie darnumą apskritai bei vis neịvykstantị jo praktinị igyvendinimą, galima daryti prielaidą, kad taip atsitinka dèl to, kad darna nèra kažkoks fiksuotas baigtinis rezultatas. Keičiantis aplinkos sąlygoms, žmonių poreikiams, politinei sistemai ir pan. (tokie procesai yra nuolatiniai ir neatsiejami nuo kasdienio gyvenimo) 
atsiranda vis naujų ir vis kitokių uždavinių. Kitaip sakant, tai, kas buvo aktualu ir gerai vakar, nebūtinai yra svarbu ir teisinga rytoj. Realiame gyvenime prie procesu dinamikos pridejjus darnumo koncepcijos platumą, iškylančios problemos tiesiog negali būti išspręstos čia pat ir greitai. Tarkime, jei šiandien visame pasaulyje būtų stabilizuota šiltnamio dujų emisija (tarša), anglies dioksido koncentracija atmosferoje - tai svarbu klimato kaitai - stabilizuotųsi tik po 100-300 metų, o pasaulinio vandens lygio kilimas dèl ledynų tirpsmo tęstųsi dar tūkstančius metų (Aresta 2010; IPCC 2007a). Toks pat (skiriasi tik intervalo trukmè) vélavimas vyksta ir kituose darnaus vystymosi sektoriuose, pavyzdžiui, investuojant $i$ švietimo sistemos, geriamojo vandens ir pan. infrastruktūros plètrą Libijoje, bet, pasikeitus politiniam režimui, viską gali tekti sustabdyti arba daryti iš naujo kitoje vietoje. Be to, rezultatai apdorojami ir revizuojami jau po atliktų veiksmų, praejjus laikui, problemą didina tai, kad vertinimo metu atsiranda kitu ivykių, kurie gali atskleisti rezultatus kitais rakursais. Todèl praktiškai darnus vystymasis visada yra uždelsto veikimo ir neatsiejamas nuo vélavimo, tai yra nuolatinis procesas, kurio metu gali ịvykti nenumatytų trikdžių, savo ruožtų pareikalausiančių tam tikrų korekcijų. Ir būtent šioje - korekcijų ịvedimo vietoje darnumo koncepcija, vertinant jos visumą, skiriasi nuo atskirų jos komponentų ir ypač akivaizdžiai ekologijos.

Trikdis 1

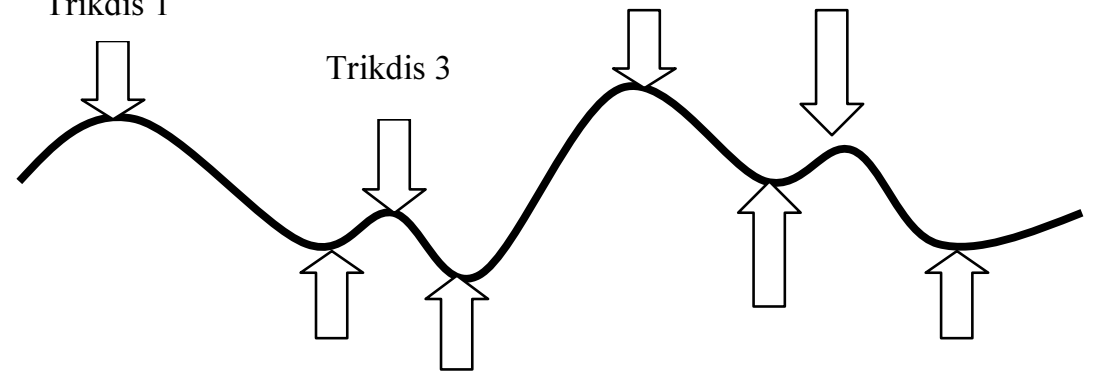

Trikdis 2

Trikdis $n$

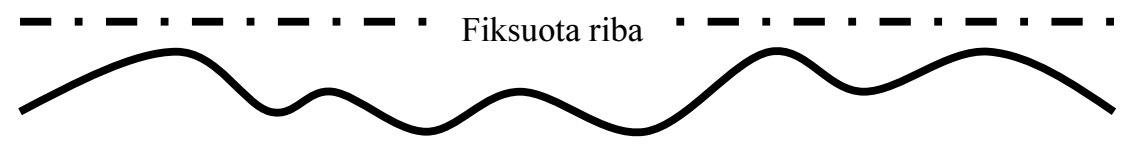

Laikas

2.1 pav. Darnus vystymasis ir ekologija

Fig. 2.1. Sustainable development and ecology 
Iliustruojant skirtumą, galima remtis dinaminių sistemų ir katastrofų teorijos (Nijkamp and Reggiani 1995; Wilson 2002; Mayer 2008; Chen 2009; Berwald et al. 2012) pavyzdžiu. Dinaminè sistema, veikianti tam tikromis sąlygomis, pasižymi nelinijiniais santykiais ir atsakomaja reakcija tarp jos komponentų. Sistema veikia normaliai ir be esminių trikdžių tol, kol yra pakankamai sistemos vidiniu resursų atlaikyti vykstančius pokyčius ir atsistatyti. Kai tam tikri parametrai priartejja prie ribinių verčių, net ir nedidelis papildomas parametrų pokytis tampa reikšmingas visai sistemai: sistema išbalansuojama, tampa nestabili ir „keliauja“ i naujaji režimą, kuriame formuojasi nauji santykiai ir atsakomosios reakcijos. Ši teorija gerai atskleidžia darnumo išsitęsimą laiko požiūriu ir procesų bangavimą, tačiau, kalbant apie ekologiją, atsiranda migravimo krypties apribojimai, kai viena iš galimų migravimo krypčių tampa ypač nepriimtina. Ekologijos specialistai ịvardina negrį̌tamumo problemą, t. y. fiksuotą ribą, kurią viršijus pasekmès yra nebeatstatomos ir nekoreguojamos (pastaruoju metu taip atsitinka su tam tikromis gyvūnų / augalų rūšimis, kurios paskelbiamos nykstančiomis arba ties išnykimo riba). Baigtinis rezultatas iš principo kitoks nei nuolatinè darnos dinamika: pasiekus lūžio tašką, bet kokie veiksmai tampa beprasmiai, derybos neimanomos. Ši procesą taikliai užfiksavo Alanas Goras, buvęs kandidatas ị JAV prezidentus, filme „Nepatogi tiesa“: 77 minutę ekrane rodomos svarstyklès, kurių vienoje pusèje yra Žemès planeta, o kitoje - aukso luitai. A. Goras pastebi, kad toks svèrimas iš esmès yra klaidinantis dèl dviejų dalykų, iš kurių pirmasis - ,jei neturètume planetos..." Todèl esminis dalykas, kalbant apie ekologini darnos komponentą, yra negrižtamai „nepralošti“, t. y. neviršyti kritinès ribos, šis faktorius išlieka aktualus ir analizuojant miestų ekologiją (kaip subkomponentą didesnès pasaulinès ekologijos) (2.1 pav.). Kritinès ribos detaliau nagrinejjamos 2.3 poskyryje.

Toliau rutuliojant miestų ekologijos temą ir ją analizuojant darnaus vystymosi kontekste, neišvengiamai bus susidurta su tradicine ekologijos mokslo specifika, kuri dèl jai būdingo tam tikro uždarumo neatitinka darnaus vystymosi ypatumų. Dalis specialistų (Alberti et al. 2003; Grimm et al. 2000; McDonnell et al. 2009) jau seniai taikliai pabrěžia tradicinių miesto ekologijos tyrimų silpnają vietą: dažniausiai tiriama, kaip urbanizuotos teritorijos veikia gamtinę aplinką, kokią ịtaką daro tam tikroms pasirinktų gyvūnų (augalų) populiacijoms arba yra atliekamas miesto ir užmiesčio ekosistemų palyginimas, t. y. žmonès, miestiečiai, a priori suvokiami kaip kažkas esantis šalia, izoliuotas, neliečiamas būvis. Toks požiūris iš esmès yra stipriai ribotas, nes būtent miestai yra labiausiai veikiami žmonių, vartojant ekologų terminologiją, tai yra ,žmonių dominuojama ekosistema“" (Vitousek et al. 1997). Siekiant dirbtinai neapsiriboti, miesto ekologiją būtina vertinti kompleksiškai kaip visumą, kur žmonès yra viena iš sudedamujų (nors ir varomoji, esminè) dalių. Šiame darbe miestų 
ekologiją suvokiant kaip neatskiriamą darnaus vystymosi komponentą, pritariama aukščiau išsakytai pozicijai dèl žmonių neišskyrimo, juos matant kartu ir greta kitų biologinių formų. Dèl tų pačių priežasčių miestų ekologija analizuojama neapsiribojant administracinèmis (miestas, užmiestis ir pan.), geografinèmis (miestas prie jūros, miestas žemyne ir pan.), politinèmis (Lietuvos miestas, Italijos miestas ir pan.) ar kitomis sintetinemis ribomis, dirbtinai sukurtomis žmonių, tačiau kurių nepažịsta ir kurioms nepavaldūs ekologiniai procesai. Specialiai sukonstruotos ribos sudaro pavojingas situacijas, kai unikalūs, nepakeičiami gamtiniai procesai nyksta, tačiau yra maskuojami dirbtiniais produktais, nepajègiais atstoti natūralių. Sukuriamos palankios sąlygos (dažniausiai išsivysčiusioms valstybèms) dirbtinai spekuliuoti statistiniais duomenimis ir deklaruoti statistiškai geresnę situaciją nei yra faktiškai, ịvyksta nutekejjimo (leakage) efektas (Morse and Fraser 2005).

Darbe laikomasi pozicijos, jog miestų ekologijos procesai turi būti vertinami dvejopai priklausomai nuo poveikio krypties. Pirmu atveju, kai tiriamas miesto poveikis ji supančiai aplinkai ir vertinama iš paveiktosios pusès pozicijos (objekto), laikoma, kad poveikis nukreiptas ị išorę. Analizuojama, dèl kokių ekologinių pokyčiu yra „kalti“ miestai, tačiau visiškai nenagrinëjama pokyčių itaka patiems miestams. Tokiu atveju iš anksto atmetamos bet kokios administracinès ir pan. ribos. Antru atveju situacija priešinga: tiriamas miesto poveikis ji supančiai aplinkai iš miesto pozicijų, kitaip sakant, miesto poveikis sau pačiam. Šiuo atveju miestas traktuojamas ir kaip subjektas, ir kaip objektas, be to, poveikio zona ribojama administracinemis miesto ribomis. Remiantis poveikio kryptimi, pirmasis atvejis vadinamas miesto išorine ekologijasujungus $\mathfrak{i}$ visumą, gaunamas visapusiškas, kompleksinis vaizdas ir - tai svarbu - dirbtinai neapribotas rezultatas.

Sugretinus darnų vystymąsi su vienu iš jo komponentų, ekologija, atsiskleidžia aiškus skirtumas tarp darnos apskritai ir sudètinių dalių pavieniui:

- darnus vystymasis yra suprantamas kaip nuolatinis procesas, kurio rezultatai visada vèluoja ir kuris gali būti nuolatos koreguojamas;

- ekologiniai procesai gali būti koreguojami, tačiau egzistuoja „lubos“, kritinès vertès, kurias viršijus procesai tampa negrižtami.

Miesto ekologiją siūloma vertinti pagal poveikio krypti, t. y. vertinti miesto išorinę ekologiją (miesto poveikis aplinkai, atmetant bet kokias dirbtines ribas) ir miesto vidinę ekologiją (miesto poveikis pačiam sau miesto administracinèse ribose). 


\subsection{Miesto ekologijos struktūra}

Laikantis 2.1 poskyryje išsakytos minčiu sekos, miesto ekologijos modeli siūloma konstruoti iš dviejų lygių: išorinio ir vidinio. Prioritetinè seka, nuo kurio lygmens pradèti struktūros detalizaciją, techniškai nèra svarbi, tačiau, prisimenant tradicinès ekologijos tyrimų kritiką, akivaizdu, kad dažniausiai analizuojama ekologijos dalis susijusi su vidiniais procesais. Turimas omenyje ne „užsidarymas“ miesto administracinèse ribose, bet idejjinis ribotumas, t. y. ekologinių procesu ,iškirpimas“ ir visuminio vaizdo fragmentavimas. Lokalių ekologinių problemų nustatymai ir tyrimai gali būti priimtinesni ar lengviau suvokimai ir dèl mažesnès apimtis, tai, kas yra toliau ir apima daugiau komponentų, dažniausiai yra imlesni tyrimo laikui, reikalauja plataus konteksto, gebejjimo apčiuopti tarpdisciplininius ryšius ir pan. Todèl tai, kas yra toliau, dažnai lieka nepastebèta arba mažiau tyrinèta, kaip taikliai ịvardino White (2013): „sužinau tada, kai pamatau“.

Disertacijos ịvade buvo minèta ekologijos rodikliu gausèjimo tendencija (dažniausiai nesuteikianti proporcingai daugiau aiškumo) ir deklaruotas siekis dirbti su jau apibendrinta informacija, siekiant sukonstruoti kaip imanomą visapusiškesni ir aiškesni miesto ekologijos vaizdą. Pasirinktą darbo krypti galima (iš dalies) palyginti su Makso Vèberio (Max Weber) „idealiujų tipų“ konstravimo teorija (remiamasi Bauman 2007), kuri leidžia sukurti abstrakcijas, apibrežiančias unikalias situacijas, sudarytas iš ne unikalių, kitur aptinkamų elementu. Sukurtos abstrakcijos nèra tikrovès atvaizdavimas, tai priemone jai tirti ir suvokti, todel konstruojant „,idealiuosius tipus“ vieni aspektai sąmoningai sustiprinami, o kiti nukeliami i antrą planą. Toks modelis leidžia ịvertinti esamą situaciją atsitraukus, pažiūrèti i jau žinomus faktus analitiškai. Disertacijos rèmuose „idealieji tipai“ suvokiami kaip (neunikalių) ekologinių procesų perkèlimas i (unikalią) miesto aplinką, tipai reikalingi išorinei bei vidinei miesto ekologijai konstruoti ir sudètinèms dalims atskleisti.

Atsižvelgiant i darbo praktini siekị, sąvoka „visuminis miesto ekologijos vaizdas" apibrěžiama ne tradicine - smulkesnè, turinti daugiau rodiklių ir / ar tirianti kuo daugiau sričių - samprata, bet indikuojama i specifinę bendrujų planų ypatybę: apibendrintą, ilgalaikị (10-20 metų) ir strategini (nepainioti su planavimo tipu) miestų valdymą. Valdymo tipą, kai reikalingi principiniai veiksmai labiausiai pažeistose (t. y. nebūtinai smulkmeniškai visose) srityse, taigi šiuo požiūriu miestų bendrujų planų rengimas yra panašus i $E S$ subsidiarumo principą, skatinanti veikti efektyviausiu lygmeniu. Tokio planavimo specifiką pagrindžia faktas, kad, rengiant miestų bendruosius planus, darbui atlikti yra nustatomas fiksuotas laikas, dažniausiai nesudarantis sąlygų atlikti išsamių vietos tyrimų. Vadinasi, konstruojant miesto ekologijos modeli, tinkamą planavimo praktikai, turètų būti kalbama apie būtinus ir bendrus 
daugumai kriterijus, o planavimo sèkmè slypi principinėse gairèse, kurių pagrindu galima tolesnè smulkesnè detalizacija (pvz., ruošiant detaliuosius planus ir / arba techninius projektus).

Darbe yra pristatomas visuminis (apimantis išorinę ir vidinę) miesto ekologiją modelis, tačiau, atsižvelgiant i aukščiau išdèstytą informaciją, konstravimas pradedamas nuo išorinès miesto ekologijos. Akcentuojamas idejjinis šio ekologijos tipo miestuose būtinumas, faktinis modelio nebuvimas ir jo vertinimo miestu planavime poreikis. Miesto išorinè ekologija apibrèžia ir disertacijos ribas: kuriama sistema ir skaičiavimo modelis, kurie leidžia planuotojams, rengiant miestų bendruosius planus, kiekybiškai įvertinti miesto išorinę ekologiją. Miesto vidinès ekologijos klausimai i disertacijos ribas patenka tik iš dalies, tiek, kiek reikia visuminiam miesto ekologijos modeliui suvokti. Detaliau ji nedetalizuojama dèl dviejų priežasčių: iš principo ši miesto ekologijos dalis (bent jau dalinai ar netiesiogiai) yra labiau tyrinèta, todèl manoma, kad išoriné miesto ekologija „turi“ daugiau mokslinio naujumo (tačiau pripažistama, kad nuoseklumo ir tinkamo adaptavimo miestų planavimui nèra) ir disertacijos rèmuose abiejų miesto ekologijų tyrimas būtų paviršutiniškas dèl didelių tyrimo sąnaudų, todèl galutiniais rezultatais nebūtų galima remtis praktikoje.

Laikantis aukščiau išsakytos logikos, naudinga glaustai apžvelgti apskirtai šiuo metu pasaulyje aktualiausias ekologines problemas ir tiketina, kad jų fone atsiskleis tai, kuo svarbūs miestai, vartojant darbo terminus, - miesto išoriné ekologija. Identifikuoti, kas iš ekologinès pusès šiuo metu pasaulyje yra ypač aktualu, nesunku, tačiau su viena sąlyga. Net ir akivaizdžiausios problemos gali būti sukritikuotos ir paneigtos joms priešpastatant kitus atskaitos taškus, kitaip sakant, viską galima vertinti reliatyviai. Darbe siekiama vengti ginčytinų teiginių ir iš to kylančių betikslių diskusijų, todèl konkrečiu atveju žodžiu „,aktualu“ ivardinama problema, kurią yra pripažinusios stambiausios tarptautinès organizacijos, savo veikla susijusios su aplinkos klausimais. Tokios informacijos surinkimas ir apdorojimas yra imlus laikui, todèl informacija gali nebūti pati naujausia lyginant su pavienių specialistų atliekamais tyrimais, tačiau,

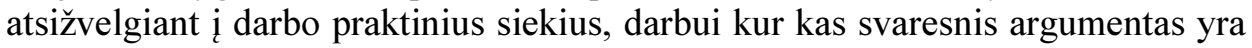
informacijos ,svoris“: organizacijų publikuojama medžiaga yra parengta daugelio specialistų, vadinasi, ji yra susisteminta ir maksimaliai patikima.

Aktualiausia (iš principo dèl teiginio sutariama ir yra daug teigini pagrindžiančių faktų) šių laikų pasaulinè ekologinè problema (ivardinama net ir kaip grèsmé visos žmonijos saugumui) - klimato kaita (IPCC 2007b; McMichael et al. 2003; UNEP, UNICEF, WHO 2002; Parry 2007). U.S. EPA (2013) teigia, kad: „klimato kaita, ko gero, ivvardijo pasaulio tautas potencialiai vienijantị tvarumo klausimą, nes reikšmingi klimato kaitos pokyčiai mums visiems turi itakos“. Savaime klimato kaitos procesas iš principo nèra 
pavojingas, pavojingi yra su tuo susiję rezonansiniai reiškiniai (pvz., temperatūriniai ekstremumai, sausros, potvyniai ir pan.), o daugiausia problemu pastaraisiais dešimtmečiais kelia visuotinis klimato šilimas. Prie jo, arba, tiksliau nurodant priežastį, prie šiltnamio efektą sukeliančių dujų koncentracijos didejjimo, prisideda ịvairios antropogeninès veiklos rūšys, pavyzdžiui, pramonès procesai, žemès ūkis ir pan. Skirtingos veiklos susijusios su ịvairiomis išmetamosiomis dujomis, tačiau tiek pasaulyje, tiek Europos Sajungoje didžiausią emisijos dali sudaro anglies dioksidas ir metanas: $2004 \mathrm{~m}$. anglies dioksidas sudare beveik $77 \%$ pasaulinès šiltnamių dujų emisijos, metanas $14 \%$; $2009 \mathrm{~m}$. anglies dioksidas sudare $80 \%$ visos ES (ES-27) emisijos, metanas - $9 \%$ (Barker et al. 2007; UNFCCC 2009). Vertinant viso pasaulio mastu, per 34 metų laikotarpi nuo $1970 \mathrm{~m}$. iki $2004 \mathrm{~m}$. anglies dioksido emisija padidejo $80 \%$, o metano - $40 \%$ (Barker et al. 2007). Minètą statistinę informaciją vertinant miestų planavimo kontekste ir atmetant dirbtines (administracines, politines) ribas, darytina išvada, kad miesto išorinę ekologiją prasminga sieti su miesto „indèliu“, t. y. poveikiu klimato kaitai, tiksliau, su šiltnamio efektą sukeliančių dujų ribojimu (valdymu). Siekiant praktinio sprendimo miestų planavime, būtina nustatyti, kas, kur ir kodèl išskiria šiltnamio dujas ir - kas ne mažiau svarbu - sužinoti kokia riba yra nepavojinga (didžiausia leidžiama koncentracija)?

IPCC nurodo kelis sektorius, kurie yra ypatingai susiję su šiltnamio dujų emisijomis, tokius kaip energetikos, pramonès procesu arba atliekų tvarkymo, tačiau vieningos pasaulinès metodikos nèra: ivvairios tarptautinès organizacijos yra pateikę šiek tiek skirtingus aprašus su nurodytais kertiniais indikatoriais / veiklos sritimis. Dažniausiai tai priklauso nuo to, kokios veiklos kam priskaičiuojamos, pavyzdžiui, transporto indèlis gali būti priskirtas energetikos sektoriui, tačiau, atsižvelgus i šiandieninę transporto svarbą ir sektoriaus plètrą, ši sritis gali būti analizuojama kaip savarankiška ir reikalaujanti atskiro valdymo. Sprendžiant pagal stambiausių tarptautinių organizaciju - UN, IPCC, OECD - ataskaitas, pasaulyje labiausiai šiltnamio efektą sukeliančių dujų koncentracijos didejimą lemia energetikos sektorius (Barker et al. 2007; OECD 2003; UNFCCC 2009). Analogiška situacija ir Europos Sajungoje, kur energijos sektoriui tenka $80 \%$ visos emisijos, pakui seka žemès ūkio (10\%), industrinių procesų (7\%), atliekų (3\%) ir tirpiklių panaudojimo sektoriai (UNFCCC 2009). Vadinasi, miestu išorinè ekologija turètų būti suvokiama kaip šiltnamio dujų emisija, generuojama dèl miesto energinių poreikių, ir miestų išorinès ekologijos pagrindinis uždavinys būtų miestų energinių poreikių valdymas. Anglies dioksidas kartu su metanu sudaro 89 \% visos ES emisijos, todèl būtent šioms dujoms ES (taigi ir Lietuvoje) turètų būti skiriamas didžiausias (strateginis) dèmesys. 
Remiantis apibendrintomis ataskaitomis, nustatyti, kad pagrindinis šiltnamio dujų emisijos kaltininkas miestuose yra energetikos sektorius iš esmès nesudètinga: statistiniai duomenys rodo ryškų atotrūkį nuo kitų sektorių. Užfiksuoto skirtumo privalumas dar ir tas, kad būdamas toks didelis, jis labai aiškiai ir vienareikšmiškai atskleidžia pagrindinę problemą, tačiau, renkant kitus miestų ekologijos komponentus, nustatyti, kokios kitos veiklos rūšys miestuose yra svarbios, komplikuota. Kitaip sakant, tolesnis ejjimas iš viršaus i apačią, remiantis statistiniais duomenimis, pateikia nebe tokius apčiuopiamus ir aiškius rezultatus: dujų emisijų skirtumai tampa mažiau ryškūs, sektorinis priklausomumas labai diferencijuotas ir pan., o norint, kad sprendimai būtų praktiškai efektyvūs, būtinas visuotinis pripažinimas ir bendras veiksmų planas. Mažai tikètina, kad individualus vieno specialisto sprendimas, kad ir koks geras ir ištobulintas jis būtų, sulauktų tinkamos vieningos reakcijos, todèl miestų ekologijos modeli toliau logiška konstruoti naudojant patikrintą grupinị darbą (pvz., mokslinių darbo grupių ir pan.), kuris, kaip jau minèta, neturètų būti pats naujausias. Laiko intervalas leistų minètam darbui būti plačiau ịvertintam mokslo visuomenès ir praktikų, informaciją būtų galima patikrinti kitų tyrimų kontekste.

Reikètų pabrèžti, kad tokių verčių, kurios būtų visų pripažintos kaip svarbios, labai ilgai nebuvo (tam įtakos ko gero turejjo faktas, kad ir pati darnaus vystymosi koncepcija yra sąlyginai nauja žiūr. 2.1 poskyrị). Tinkamu pavyzdžiu laikytina šiek tiek daugiau kaip prieš dešimtmeti, 1999 m., ES pradèta Europos bendrujų indikatorių iniciatyva (European Common Indicators (ECI)). ECI iniciatyva buvo pradèta suburiant specialią darbo grupę, kuriai buvo pavesta pasiūlyti bendruosius indikatorius, užtikrinant, kad vietos valdžia galètų stebèti miesto aplinkos kokybės pokyčius (atlikti subalansuotos plètros monitoringą) (Tarzia 2003). Užsibrèžtas tikslas (panašiai kaip disertacijos) pareikalavo ne daugelio, o būtent esminiu bendruju parametrų atrinkimo, todèl galutinis rezultatas buvo (tik) 10 indikatorių rinkinys, iš principo tinkantis visiems ES miestams ir, kas ne mažiau svarbu, pasiūlytas bendradarbiaujant daugeliui šios srities ekspertų, ES bei nacionalinèms institucijoms. Indikatorių skaičiaus mažinimo tendencijai pritaria ir OECD, kaip pagrindinę priežastį nurodant, kad mažas parametrų skaičius yra lengviau suvokiamas paprastiems miestiečiams bei užtikrina glaudesni (taigi ir efektyvesnị) valdžios kontaktą su visuomene (OECD 2008). Rengiant miestų bendruosius planus, OECD pastebètos priežastys yra ypač aktualios siekiant realių rezultatų, nes nespecialistams (visuomenei) planavimas dažnai pasirodo per sudetingas, nesuvokiamas ir visuomenès ịtraukimas dažnai telieka formalia procedūra.

Vertinant tik pagal datą, gali pasirodyti, kad minètas rinkinys yra per senas ir nebeaktualus, kad būtų nagrinejjamas rengiant disertaciją, tačiau toks vertinimas būtų paviršutiniškas, ignoruojantis rinkinio turinị, jo atsiradimo 
kontekstą ir juridines europines miestų planavimo realijas. Pirma, Europos Komisija minèto rinkinio metodiką yra pateikusi oficialiame puslapyje, skirtame urbanizuotai aplinkai kartu su tokios svarbos dokumentais kaip Teminè miestų aplinkos strategija, 5-oji ir 6-oji aplinkosaugos veiksmu programos (aplinkosaugos programos naudojamos ES aplinkos apsaugos politikai nuo 8-ojo dešimtmečio (EEB 2013; EC 2013b)), Žalioji knyga dèl miestų aplinkos ir pan. (EC 2012a). Antra, $2013 \mathrm{~m}$. pradžioje jokia kita vieninga metodologija nebuvo publikuota ir, ivertinant reikalingą laiką tokiam darbui atlikti, manoma, kad disertacijos laikotarpiu ji nebus parengta. Be to, net ir parengus naują metodiką, abejotini kitokie prasminiai akcentai. Trečia, rinkinyje užfiksuotos vietos, kuriose specialistų manymu, atsiskleidžia miestų sąlytis su darnaus vystymosi koncepcija, t. y. bandyta praktiškai pamatuoti darnaus vystymosi (vadinasi, ir visų sudetinių dalių) progresą miestų lygmenyje.

2.1 lentelè. 10 bendrujų Europos indikatoriu

Table 2.1. The 10 European Common Indicators

\begin{tabular}{|c|c|c|}
\hline $\begin{array}{l}\text { Eil. } \\
\text { Nr. }\end{array}$ & Pavadinimas & Pagrindinis indikatorius \\
\hline 1. & $\begin{array}{l}\text { Piliečiu požiūris ị vietos } \\
\text { bendruomenę }\end{array}$ & Vidutinis požiūris ị vietos bendruomenę \\
\hline 2. & $\begin{array}{l}\text { Vietinis ,indèlis“ i pasaulio } \\
\text { klimato pokyčius }\end{array}$ & $\mathrm{CO}_{2}$ emisija vienam gyventojui \\
\hline 3. & $\begin{array}{l}\text { Vietinis gyventojų mobilumas ir } \\
\text { keleivių vežimas }\end{array}$ & $\begin{array}{l}\text { Kelionių privačiomis motorinèmis } \\
\text { transporto priemonėmis dalis }\end{array}$ \\
\hline 4. & $\begin{array}{l}\text { Visuomenei prieinamų vietinių } \\
\text { viešujų rekreacinių zonų bei } \\
\text { vietinio paslaugų tinkle buvimas }\end{array}$ & $\begin{array}{l}\text { Gyventojų, gyvenančių iki } 300 \mathrm{~m} \\
\text { atstumu nuo viešujų rekreacinių zonų, } \\
\text { kurių plotas didesnis už } 5000 \mathrm{~m}^{2} \text {, dalis }\end{array}$ \\
\hline 5. & Aplinkos oro kokybè & Grynieji $\mathrm{PM}_{10}$ perviršiai \\
\hline 6. & Vaikų kelias ị mokyklą ir atgal & $\begin{array}{l}\text { Vaikų, keliaujančiu ị mokyklą } \\
\text { automobiliu, dalis }\end{array}$ \\
\hline 7. & $\begin{array}{l}\text { Subalansuotas vietos valdžios ir } \\
\text { vietos verslo valdymas }\end{array}$ & $\begin{array}{l}\text { Imonių, turinčių aplinkos sertifikatą, } \\
\text { dalis, palyginti su visu įmonių skaičiumi }\end{array}$ \\
\hline 8. & Triukšminè tarša & $\begin{array}{l}\text { Gyventojų, kuriuos veikia } \mathrm{L}_{\text {nakties }}>55 \\
\mathrm{db}(\mathrm{A}) \text { triukšmas, procentinè dalis }\end{array}$ \\
\hline 9. & $\begin{array}{l}\text { Subalansuotas teritorijos } \\
\text { naudojimas }\end{array}$ & Saugomų teritorijų dalis procentais \\
\hline 10. & $\begin{array}{l}\text { Produkcija, skatinanti } \\
\text { subalansuotają plètrą }\end{array}$ & $\begin{array}{l}\text { Subalansuotają plètrą skatinančius } \\
\text { produktus perkančių žmonių procentas }\end{array}$ \\
\hline
\end{tabular}


Bendrujų indikatorių iniciatyvos siekis buvo platus, apimantis visą subalansuotos plètros koncepciją, todèl analizuojant ekologinį komponentą reikalingi ne visi indikatoriai. Rinkinị sudarančių indikatoriu yra 10 (EC 2012a) (2.1 lentelè), iš jų su klimato kaita tiesiogiai susijęs yra tik vienas - antrasis (vietinis ,indèlis“ i pasaulio klimato pokyčius) - indikatorius. Jis patvirtina, kad skyrelio pradžioje nustatytas pagrindinis miesto-klimato kaitos ryšys buvo teisingas, t. y. laikoma, kad miestai turi ir gali būti siejami su klimato kaita. Indikatoriams buvo sukurta speciali metodika, todèl, remiantis antrojo indikatoriaus aprašymu, galima atrinkti keturis atraminius punktus, i kuriuos būtina atsižvelgti, konstruojant miesto išorinès ekologijos struktūros modelį.

Pirmas (ir vienas svarbiausių) dalykas yra miesto ịtakos, detalesnio „indèlio“ i pasaulio klimato pokyčius nustatymas, šiuo atveju kalbama apie tas tolesnes sekos grandis (einančias po energetikos sektoriaus), kurių nepavyko nustatyti anksčiau. Metodikoje patvirtinama, kad prie šiltnamio dujų emisijos prisideda daugelis sektorių, tačiau teigiama, kad ES „,energetikos sektorius kartu su atliekų tvarkymo sektoriumi yra pagrindinè vietos valdžios emisijos valdymo politikos sritis“" (EC 2012b), t. y. nurodoma, kad svarbiausios veiklos, susijusios su šiltnamio kaita miestuose, tèra dvi: energetikos sektorius ir atliekų sektorius. Atliekų sektorius generuoja apie $3 \%$ visų šiltnamio dujų, tačiau net 3/4 šių dujų išsiskiria iš sąvartynų (UNFCCC 2009), todèl tai yra sektorius, kuri yra daug lengviau ir pigiau valdyti (sutvarkyti) nei, pavyzdžiui, pramonès. Beje, ịdomu pastebèti, kad, igyvendinant Kioto protokole numatytus lanksčiųų mechanizmu projektus, būtent šių dviejų sektorių valdymas sulaukia daugiausia dėmesio: su energijos sektoriumi susiję projektai sudaro 74,3\% projektų, atliekų sektoriumi - 11,1\% (UNFCCC 2013a).

Antras svarbus momentas yra metodikoje nurodytas detalesnis energetikos sektoriaus išskleidimas. Skirtingai nuo atliekų sektoriaus, kuris yra pakankamai siauras, energetika apima daugiau sudedamujų dalių (energijos gamybą bei vartojimą pramoneje, buityje, transporto sektoriuje ir pan.), todèl aprašyti detaliai laiko požiūriu būtų komplikuota ir, kas aktualu kalbant apie planavimą, būtų prarastos bendrosios ižzalgos. Siekiant išlaikyti vientisumą, metodikoje siūlomas principinis energetikos sektoriaus sudedamųų dalių išskleidimas, kuris vykdomas pagal energijos suvartojimo analizę, todèl siūlomas suskirstymas apima keturias dalis: privačius energijos vartotojus, komercini sektorių, pramonès sektorių ir transporto sektorių.

Trečia: geografiniai ir atsakomybès principai. Analizuojant miestus pasaulinių ekologinių problemų kontekste, išryškèja vienas esminis skirtumas: miestai užima tam tikrą žemès plotą, t. y. turi aiškias administracines ribas, o ekologinès problemos aktualios be ribų, t. y. pasekmès gali būti jaučiamos nepriklausomai nuo to, kur buvo reiškinio epicentras. Metodikoje siūloma geografini principą pakeisti atsakomybès principu, todèl yra îvedamos dvi 
sąvokos - „emisija skolon“ ir „emisija kreditan“. Šias sąvokas galima iliustruoti tokiu pavyzdžiu: miesto gatvių apšvietimui reikalinga elektros energija gaunama iš elektrinių, kurios nèra miesto teritorijoje, tačiau emisija, susidaranti elektros gamybos metu, turètų būti priskirta konkrečiam miestui (miestams), o ne elektrinei, kitaip sakant, tai yra miesto „skola“. Kita vertus, miestas gali gauti ir „ekologinių kreditu“", tarkime, jei didesnis miestas turi atliekų deginimo stoti, tai joje atliekos galètų būti deginamos ne tik surinktos tame mieste, bet ir iš gretimų, aplinkinių miestelių. Galutinis miesto ekologinis rezultatas turètų būti gaunamas trimis pakopomis: suskaičiuojama emisija miesto teritorijoje, pridedama „emisija skolon“ ir atimama „emisija kreditan“.

Ketvirta: vertinimo principai. Atsižvelgiant i metodiką, reikètų papildyti anksčiau iškeltą klausimą apie ribų nustatymą. Apskritai kalbant apie ribas, turimas omenyje absoliučių verčių nustatymas, o metodikoje akcentuojama, kad miestų ìvertinimas pagal kasmetines emisijas turètų būti atliekamas labai atsargiai, nes miestuose vyksta daug procesų, nepriklausomų nuo planavimo, pavyzdžiui, vejo jẻgainès, skirtos sumažinti miesto energetiniams poreikiams, gaunamiems deginant naftos produktus, yra efektyvios tik tose vietose, kuriose yra pakankamas vejjuotumas. Todèl metodikoje siūloma remtis ne tik absoliučiomis vertėmis, bet ir emisijos kaita bejgant laikui, t. y. vertinti planavimo pasekmes (kryptį).

Aptartas indikatorius papildo jau anksčiau nustatytą „kaltininką“ energetikos sektorių - atlieku sektoriumi ir tuo pat metu pakankamai detaliai parodo, kad didžiausią ittaką pagrindinei pasaulinei ekologinei problemai klimato kaitai (atšilimui) - miestuose daro energetikos ir atliekų tvarkymo sektoriai, tiksliau, šiuose sektoriuose generuojama šiltnamio dujų (iš kurių svarbiausios anglies dioksidas ir metanas) emisija. Šie du komponentai ir sudaro miesto išorinę ekologiją.

2.2 poskyrio pradžioje buvo nurodyta, kad darbo ribos sietinos su miesto išorine ekologija, todèl dabar, kai išorinès miesto ekologijos dalys yra galutinai apibrežtos, tikslinga dar kartą sugrį̌zti ir patikslinti darbo ribas. Vidiniai pramonès procesai, nors ir svarbūs iš ekologinès pusès, faktiškai yra per smulkūs, kad būtų sprendžiami miestų bendruosiuose planuose, be to, nèra aiškių teisinių priemonių, kaip tuos procesus suvaldyti. LR teisès aktuose (specialiosios žemès ir miško sąlygos) yra vienintelis apribojimas, nurodantis, kad taršius objektus reikia atskirti nuo gyvenamujų rajonų, t. y. miestuose taršių pramoninių objektų statyba yra labai ribota arba išvis neleidžiama. Pramonès klausimų aktualumą Lietuvoje mažina ir faktas, kad didieji taršūs pramoniniai objektai buvo pastatyti iki nepriklausomybès atkūrimo, o vèliau pastatyti gamybos objektai yra labiau priskirtini komercinei veiklai. Transporto sektoriaus spartus vystymasis po $1990 \mathrm{~m}$. sąlygojo visiškai priešingą situaciją. Miestų planavimo praktikoje (ir apskritai miesto gyvenime) transporto sritis užèmè 
svarbią ir dažniausiai atskirą vietą: rengiamos transporto galimybių studijos, vertinami ir prognozuojami transporto srautai, renkamos transporto rūšys, nustatomos reikalingos gatviu kategorijos ir pan., be to, planuojant didesnius miestus, planavimas neįmanomas be atskirų šios srities specialistų. Atsižvelgiant i nusistovejusią Lietuvoje miestų planavimo specifiką, transporto sriti būtų tikslinga traktuoti kaip savarankišką ir tiek svarbią, kad vien šios srities tyrimai yra verti atskirų darbų (Griškevičiūtè-Gečienè and Burinskienè 2012; Laurinavičius et al. 2012; Jasiūnienè and Čygas 2013). Nors transporto sektorius, vertinant iš ekologinių problemų perspektyvos, yra priskiriamas energetikos sričiai, atsižvelgus i praktini disertacijos sieki, transporto klausimai disertacijoje detaliau nenagrinejjami. Už disertacijos ribų suvokiamas ir pramonès procesų valdymas, juos, ịvertinus Lietuvos specifiką, traktuojant kaip nepavaldžiais miestų planavimo priemonèms.

Apibrèžus miesto išorinès ekologijos rèmus ir komponentus, liko neatsakyta, kas yra svarbu patiems miestams, t. y. miesto vidine ekologija. Tarp miesto „vidaus“ ir "lauko" glūdi esminis skirtumas: tai, kas svarbu miesto viduje, gali būti nesvarbu pasauliniu lygiu ir atvirkščiai. Tokią nepriklausomybę geriausiai iliustruoja keli pavyzdžiai. Tarkime, sąlyginio miesto, kuriame gyvena 100000 gyventojų, pagrindinè gatvė yra nutiesta per gyvenamuosius rajonus. Dèl nuolatinio intensyvaus vietinio ir tranzitinio transporto eismo tuose rajonuose gyvenantys žmonės yra nuolatos veikiami padidejjusio triukšmo ir yra priversti kvejpuoti oru, kurio tarša viršija higienos normas. Vadinasi, konkrečiai tuose rajonuose vidaus gyvenimo sąlygos yra kenksmingos ir žmonès patiria neigiamą poveiki. Kita vertus, vertinant globaliai, 100000 gyventojų miesto transporto „indèlis“ i pasaulinę šiltnamio dujų emisiją nèra statistiškai svarbus. Šis modelis veikia ir atvirkščia seka. Pavyzdžiui, dèl bendro klimato atšilimo Afrikoje didèja sausringų dienų skaičius, todèl ten gyvenantiems žmonèms vis sunkiau gauti geriamo arba žemès ūkiui reikalingo vandens, tačiau daugumai industrializuotų valstybių miestų gyventojams ši problema nèra fiziškai juntama (todèl daugumai sunkiai ịsisąmoninama ir nesvarbi).

Galima drąsiai teigti (ir tai bus teisinga), kad kiekvienas miestas pasižymi tam tikra individualia specifika ir miesto vidaus procesai yra unikalūs. Tačiau, kaip jau buvo minèta, siekiant, kad sprendimai būtų praktiškai efektyvūs, būtinas visuotinis pripažinimas ir bendras veiksmų planas, vadinasi, būtina apibrèžti pagrindines bendramiestines vidaus problemas (esant reikalui, jos gali būti praplèstos vietos problemomis). Bendrujų indikatorių rinkinyje yra du indikatoriai, kurie taip pat galètų turèti ryši su ekologija, kuri šiuo atveju būtu nukreipta i miestą, jo vidinę ekologiją. Konkrečiai tai yra penktasis ir aštuntasis indikatoriai: aplinkos oro kokybè ir triukšminè tarša. 
Klimato kaita (išorinis procesas)

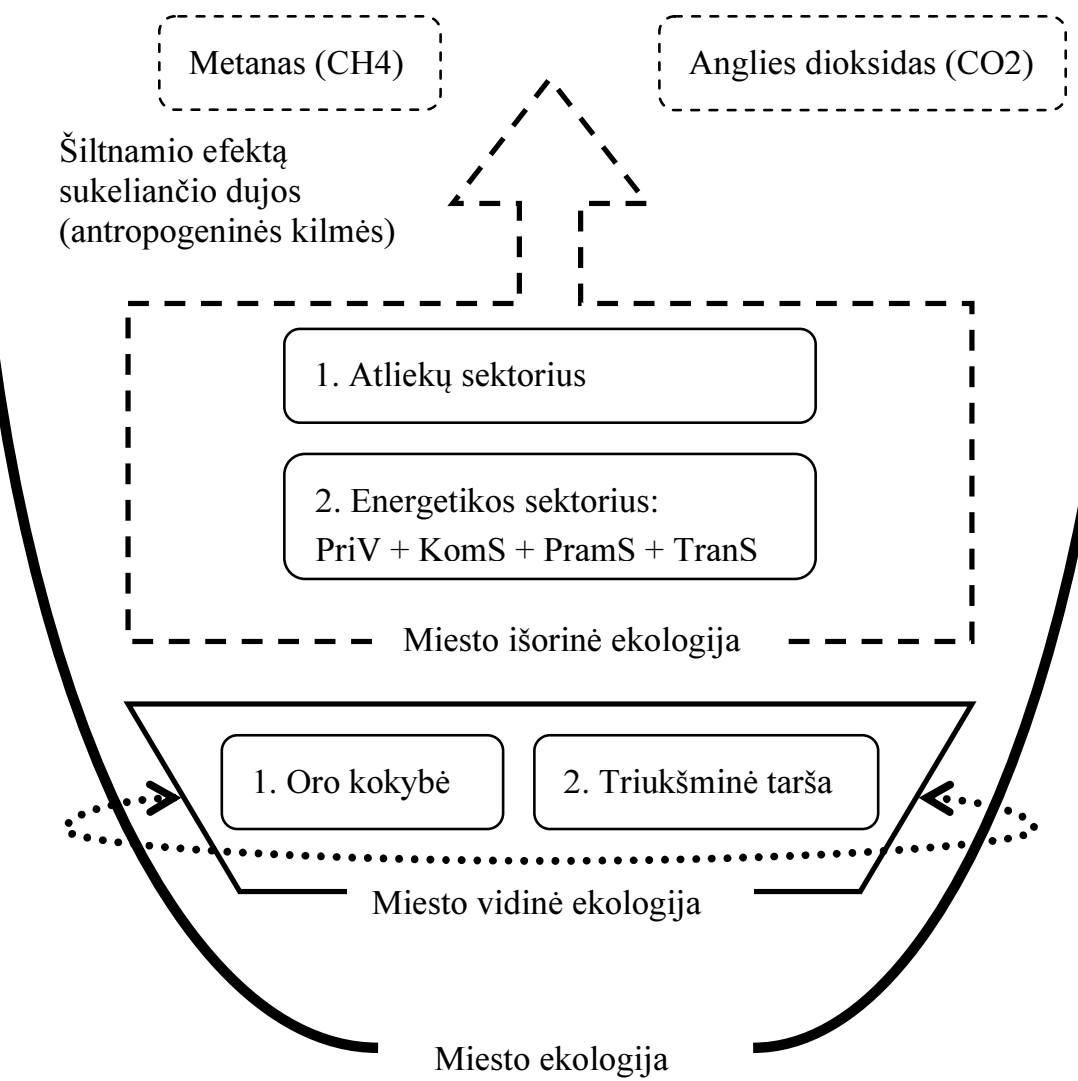

2.2 pav. Miesto ekologijos sampratos struktūra

Fig. 2.2. Structure of the ecology of city

Pastabos: PriV - privatūs energijos vartotojai, KomS - komercinis sektorius, PramS - pramonės sektorius, TranS - transporto sektorius

Aplinkos oro kokybę, kaip ir klimato šilimą, nulemia tam tikrų teršalų kompleksas, tik šiuo atveju pasekmès yra ypač jaučiamos vietiniu lygiu, pavyzdžiui, astma, žmonių darbingumo mažejjimas, širdies ligos ir pan. Yra nustatyta, kad pagrindiniai ES miestų oro taršos kaltininkai yra degimo procesai, generuojami susisiekimo ir šildymo sistemose bei pramoneje (EC 2012b). Penktojo indikatoriaus metodikoje yra ivvardyti pagrindiniai teršalai, kuriu yra septyni: sieros dioksidas, azoto dioksidas, anglies monoksidas, lakūs organiniai 
junginiai, dulkès, ozonas ir švinas. Triukšminè tarša, kaip ir aplinkos oro kokybè, yra tiesiogiai susijusi su žalingu poveikiu gyventojų sveikatai, tai taip pat miesto vidaus lokali problema, fiksuojama tam tikrose zonose. Triukšminę taršą aštuntasis indikatorius apibrèžia kaip nepageidaujamą ar žalingą garsą lauke, už kurio sukèlimą yra atsakingi (tiesiogiai ir netiesiogiai) patys žmonès. Didžiausi triukšmo skleidejai miestuose yra transporto sektorius ir pramonès procesai, todèl, vertinant šiek tiek plačiau, iš esmès atsiremiama i tą patị energetini plius pramonès - derini. Skiriasi tik tuo, kuriame mieste kuri dalis intensyvesnè (daugiau teršianti).

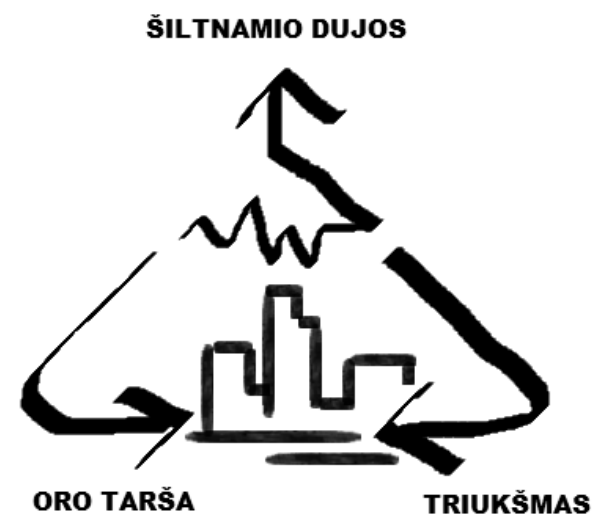

2.3 pav. Miesto ekologijos modelis pagal poveikio krypti

Fig. 2.3. Model of the ecology of city according to impact

Apibendrinant 2.2 poskyrị, bandyta miesto ekologiją išskleisti grafiškai: 2.2 paveiksle pavaizduota detali miesto ekologijos sampratos struktūra, jos elementai ir ju priklausomybė, o 2.3 paveiksle parodytas supaprastintas miesto ekologijos modelis, akcentuojant poveikio krypti, t. y. išorinę (strèlytė nukreipta išorèn) ir vidinę (strèlytès nukreiptos vidun) ekologiją.

\subsection{Miesto ekologijos kritinès ribos}

2.1 ir 2.2 poskyriuose buvo užsiminta apie gamtos ribas: vieną kartą, pažymint ekologinio darnos komponento išskirtinę, lyginant su kitais dviem komponentais, savybę - realių fizinių ribų egzistavimą, o antrą kartą minètoji savybė buvo sukonkretinta, atsižvelgiant i darbo tematiką: miesto išorinès 
ekologijos ribas prasminga sieti su miesto poveikiu klimato kaitai, t. y. šiltnamio efektą sukeliančiu dujų kiekiu.

Pirmasis pastebejimas yra tvirtas argumentas, leidžiantis pagrịsti disertacijos sprendinių įmanomumą - egzistuojant realioms riboms, teoriškai jas turi būti ịmanoma „apčiuopti““ ir išreikšti kiekybiškai. Disertacijoje terminas „riba“ apima dvi sąlygas, kurios turi būti ịvykdytos vienu metu. Pirma sąlyga: ekologinès ribos yra natūralios, egzistuojančios nepriklausomai nuo žmonių veiklos, dirbtinai nesukurtos, nesuvaržytos ir nevaldomos, tai yra tam tikras force majeure. Antropogeninè veikla gali daryti poveiki tam tikriems veiksniams, procesans, kurie aplinką ,judins“ tam tikroje fiksuotoje atkarpoje (prisimenant geometriją, turinčioje pradžią ir pabaigą) arčiau arba toliau nuo minètų ribų, tačiau pačios ribos išlieka pastovios ir nepaveikios (2.1 pav. žemiausias pavyzdys). Antroji sąlyga siejama su ribų savybe nurodyti kritinę vertę, kuri žymi ne eilinį, esantị tarp kitų pokytį, bet esminị lūžio tašką, kuris, skirtingai nuo eilinių pokyčių, gali būti tik vienas. Kalbama ne apie „šiaip“ žalą gamtai ar juo labiau bet koki neigiamą poveiki, atsižvelgiama tik i tai, kas pakeičia gamtą negrižtamai, kas iš esmès siejasi su galutine destrukcija, deformacija ir pan. Minètų dviejų sąlygų laikymasis leistų atskirti bendrą, takią informaciją nuo esminès ir tokiu atveju miestų ekologija nukreipiama i strateginius probleminius klausimus.

Vertinant išorinę miestų ekologiją (2.2 pav.), pagrindinis klausimas, kurį reikia išspręsti, yra šiltnamio efektą sukeliančių dujų emisija, iš kurių svarbiausia - anglies dvideginio ir metano emisija (analizuojamos darbe). Reikètu pabrèžti, kad dažniausiai emisija pateikiama arba absoliučia verte (sutartinis matavimo vienetas - kilogramai anglies dioksido $\left(\mathrm{CO}_{2}\right)$ ekvivalento), arba santykiniu pokyčiu, lyginant, pavyzdžiui, kasmetinius duomenis. Problema glūdi apgaulingai atrodančiuose ir daug žadančiuose skaičiuose, nes miestų planavime nei absoliučios, nei santykinès vertès pačios savaime nèra aiškios, jas būtina „skaityti“" reikalingame kontekste. Pavyzdžiui, suskaičiavus, kad mieste X absoliuti emisija yra Y ir jos pokytis per metus yra Z, to nepakaks, kad būtų galima objektyviai įvertinti ekologini , indèlic ar tuo labiau ateityje planuoti miestą tinkama kryptimi. Tai tebus matematinè ar statistiné suvestiné be galimybès duomenis pritaikyti praktikoje, todèl vertès turi būti analizuojamos tam tikrame kontekste ir, konkrečiai išorinès miesto ekologijos atveju, emisija turi būti , „ssprausta“ $i$ bendrus pasaulinès klimato kaitos remus. Šie remai ne tik nurodys maksimalią ribą, bet ir suteiks prasmę santykiniam emisijos pokyčiui, t. y. parodys, koks pokytis jau pakankamas, o koks dar per mažas.

Pagrindiniai tarptautiniai dokumentai, reguliuojantys klimato kaitą, yra Jungtiniu Tautu bendrosios klimato kaitos konvencija (JTBKKK) ir Kioto protokolas - vienintelis teisiškai ipareigojantis dokumentas, skirtas kovoti su klimato kaita (ịsigaliojo 2005-02-16). Lietuvos Respublikos Seimas JTBKKK 
ratifikavo 1995, o Kioto protokolą - $2002 \mathrm{~m}$. Kioto protokolu šalims buvo nustatyti individualūs tikslai, ir Lietuva ịsipareigojo pirmuoju laikotarpiu (2008-2012 m.) sumažinti šiltnamio efektą sukeliančių dujų emisiją 8\%, lyginant su ataskaitiniais (1990 m.) metais (UNFCCC 2013b). Pagal Kioto protokole nustatytus mechanizmus, skaičiuojamas dalyvio „emisijos biudžetas“, kuris yra lygus pradinių metų emisijai padaugintai iš įsipareigotos kvotos $(92 \%$ Lietuvos atveju) ir dar kartą padaugintas iš pasižadejjimo laikotarpio trukmès metais (pirmasis laikotarpis - 5 metai). $1990 \mathrm{~m}$. bendra šiltnamio dujų emisija visoje Lietuvoje buvo 49,4 $\mathrm{Mt} \mathrm{CO}_{2}$ ekvivalento (EEA 2012), todèl Lietuvos „emisijos biudžetas“ 2008-2012 m. buvo 227,2 $\mathrm{Mt} \mathrm{CO}_{2}$ ekvivalento. Galutinis isipareigojimų vykdymas tikrinamas periodo pabaigoje (2012 m.), todèl eigoje, pavyzdžiui, $2009 \mathrm{~m}$. emisija gali būti didesnè už vidutinę, tokiu atveju kurių nors metų emisija turètų būti mažesnè, kad būtų išlaikytas bendras balansas.

Pirmajam Kioto protokolo pasižadejimo laikotarpiui baigiantis, buvo pradètos diskusijos dèl tolesnių veiksmų, tartasi dèl antrojo laikotarpio ịsipareigojimų. Procesas nebuvo sklandus, tačiau tam tikrą bendrą sprendimą pavyko pasiekti, ir $2012 \mathrm{~m}$. gruodžio mèn. Dohoje (Kataras) buvo priimtas vadinamasis dalinis Kioto protokolo pataisymas (Doha Amendment to the Kyoto Protocol), nepasiekus susitarimo Dohoje, Kioto protokolas būtų praradęs teisinę galią jau po 23 dienų. Tiesa, Rusija, Japonija ir Kanada pasitrauke iš susitarimo, o JAV, vienos pagrindinių emisijų kaltininkių, niekada nebuvo protokolo ratifikavusi. Nuspręsta, kad antrasis laikotarpis tęsis 8 metus nuo $2013 \mathrm{~m}$. sausio $1 \mathrm{~d}$. iki $2020 \mathrm{~m}$. gruodžio $31 \mathrm{~d}$. ir šiuo laikotarpiu šiltnamio dujų emisijos turètu būti sumažintos 18\%, lyginant su 1990 m. (UNFCCC 2013c). Lietuvai nustatytas naujas „emisijos biudžetas“ yra $80 \%$, t. y. 12 \% mažesnis už buvusį pirmuoju periodu (UN 2012). Naujasis protokolas, teisiškai ipareigosiantis pasirašiusias šalis, turi būti parengtas ne vèliau kaip 2015 m., o igyvendinimas būtų pradètas $2020 \mathrm{~m}$.

ES, skirtingai nuo didžiųjų pasaulio ekonomikų, pratęsė savo ìsipareigojimus, numatytus Kioto protokole, be to, savarankiškai nagrinejja tolimesnius veiksmus, susijusius su papildomu šiltnamio dujų emisijų mažinimu. ES siekiai deklaruoti artimiausio dešimtmečio strategijoje „Europa 2020“, kuri apima penkis plataus užmojo tikslus: užimtumo, inovacijų, švietimo, socialinės itraukties ir klimato bei energijos srityse (EC 2013c). Strategijoje iškelti tikslai yra bendri visai ES ir yra numatyta iki $2020 \mathrm{~m}$. šiltnamio dujų emisiją sumažinti $20 \%$ (arba $30 \%$, jei panašiai ìsipareigotu ir kitos išsivysčiusios šalys (KOM(2010) 265 galutinis)), $20 \%$ energijos gauti iš atsinaujinančių šaltinių ir $20 \%$ padidinti energijos vartojimo efektyvumą (EC 2013c).

ES klimato ir energetikos politikos tikslams pasiekti $2008 \mathrm{~m}$. gruodi buvo patvirtintas ES klimato ir energetikos srities teisès aktų paketas (EC 2011; EC 2012c). Iš esmès išmetamieji teršalai reguliuojami dviem būdais, priskiriant 
arba nepriskiriant teršalus ES prekybos taršos leidimais sistemai (PTLS, EU Emissions Trading System (EU ETS) ir non-EU ETS). PTLS apima maždaug $40 \%$ išmetamuju teršalų kiekio ir yra reguliuojama ES lygmeniu, tačiau i ją nepatenka tokie sektoriai kaip, pavyzdžiui, transportas (išskyrus aviaciją), būstas, atliekos ir žemès ūkis, kuriems PTLS netaikoma. ES nèra vienalytis darinys, todèl, siekiant bendro tikslo, šalims narèms buvo nustatyti skirtingi nacionaliniai tikslai PTLS nepriskiriamuose sektoriuose: labiau išsivysčiusioms šalims teršalus teks labai sumažinti, o tuo neturtingos šalys turès galimybę emisijas netgi padidinti. Lietuvai kartu su tokiomis valstybemis kaip Bulgarija, Rumunija ar Estija leista teršalų kiekius padidinti, todèl Lietuvos anglies dvideginio normatyvas yra $15 \%$ didesnis (OL L 140; EC 2013d). Taigi svarbu pastebèti, kad tarptautiniu lygmeniu kalbant apie klimato kaitą, $1990 \mathrm{~m}$. emisija yra laikoma pasauliniu atskaitos tašku (1 arba $100 \%$ ), o derinant veiksmus šie metai yra atskaitos taškas ir „Europa 2020“ tikslams. Tačiau, nustatant konkrečias priemones ES viduje, bendrija naudoja $2005 \mathrm{~m}$. duomenis: PTLS sektoriai teršalų turès išmesti $21 \%$ ir ne PTLS sektoriai $10 \%$ mažiau, lyginant su 2005 m. (o ne 1990 m.) (EC 2011; EC 2012c) Todèl ir Lietuvos atveju nurodytas galimas $15 \%$ prieaugis yra susietas su $2005 \mathrm{~m}$. emisija.

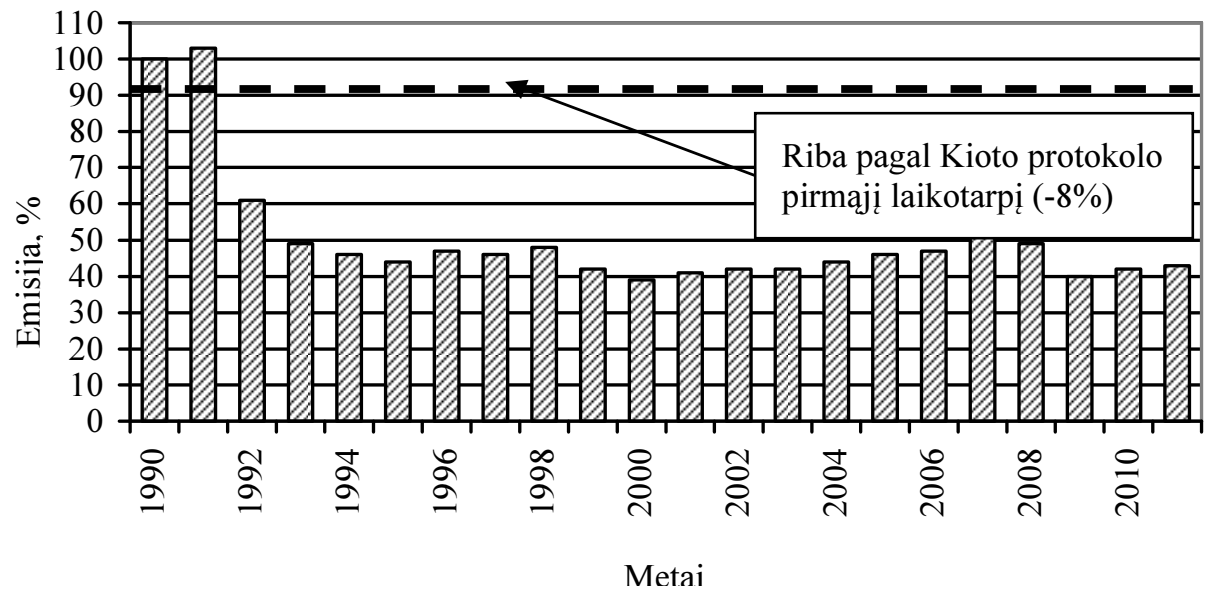

2.4 pav. Lietuvos šiltnamio dujų emisija $\left(\mathrm{CO}_{2}\right.$ ekvivalentu), lyginant su $1990 \mathrm{~m}$.

Fig. 2.4. Total greenhouse gas emissions (in $\mathrm{CO}_{2}$ equivalent) in Lithuania indexed to 1990

Apibendrinant minètą informaciją, galima konstatuoti, kad Lietuvos šiltnamio duju emisiją analizuoti miestų planavimo kontekste galima skirtingai: 1) remiantis Kioto protokolo I-uoju periodu (bent jau tol, kol nebus ratifikuotas 
naujas protokolas) arba 2) būsimojo protokolo projektinèmis vertėmis, arba 3) „Europa 2020“ iškeltu uždaviniu emisijas sumažinti $20 \%$, arba 4) „Europa 2020“ tikslais, tačiau diferencijuoti atsižvelgiant ì nacionalinius uždavinius (PTLS ir ne PTLS), arba 5) įvertinant ES svarstomą galimybę, emisijas mažinti ne $20 \%$, bet $30 \%$. Prieš nusprendžiant, kurios ribos yra tinkamiausios darbui, tikslinga detaliau aptarti Lietuvos šiltnamio dujų emisijos statistiką. Pagal susitarimą Lietuva, kaip ir kitos kovoje su klimato kaita dalyvaujančios šalys, renka duomenis apie šiltnamio efektą sukeliančių dujų emisijas ir rengia ataskaitas, kurias pateikia Europos Komisijai ir JTBKKK sekretoriatui, nuo $2004 \mathrm{~m}$. inventorius yra sudaromas pagal bendrą ataskaitu rengimo formatą (Common Reporting Format (CFR)). Remiantis statistiniais duomenimis (Eurostat 2013; EEA 2012), bendra šiltnamio dujų emisija $\left(\mathrm{CO}_{2}\right.$ ekvivalentu), lyginant su 1990 m., pateikta 2.4 paveiksle.

Iš 2.4 paveikslo akivaizdu, kad Lietuva turi gana dideli neišnaudotą „emisijos biudžetą“ (beveik dvigubą), šalis yra sąlyginai „saugioje“" pozicijoje ir galimybė viršyti $1990 \mathrm{~m}$. emisijas iki $2020 \mathrm{~m}$. nèra tikètina (EEA 2012). Tokių rezultatu priežastys nèra susijusios su ypatingai efektyviais Lietuvos veiksmais, nes $2011 \mathrm{~m}$. pagal bendrą šiltnamio dujų emisiją ne PTLS sektoriuje Lietuva užèmė tik 21 vietą iš 27 ES valstybių (EC 2012d). Gerus statistinius rezultatus būtų galima pavadinti „sèkmingu istoriniu atsitiktinumu“: atkūrus nepriklausomybę, drastiškai smuko energijos, industrinio ir statybų sektoriaus rodikliai, todèl dèl palankaus atskaitos taško $(1990 \mathrm{~m}$.) Lietuvos šiltnamio dujų emisija yra stabili ir nutolusi saugiu atstumu nuo Kioto protokolo ribos. Tokia pati gera (vertinant emisiją) padètis dèl, ko gero, tų pačių priežasčiu yra visose postsovietinèse ir buvusiose draugiškose valstybėse: Latvijoje, Estijoje, Rumunijoje, Bulgarijoje, Vengrijoje, Slovakijoje, Lenkijoje ir Čekijos Respublikoje (Eurostat 2011a). Galima daryti prielaidą, kad Kioto protokolo pirmojo laikotarpio tikslas postsovietinèms valstybèms netapo toks paveikus, koks yra, pavyzdžiui, ES senbuvėms (Danijai, Austrijai ir pan.), kurios iš tikruju turi galvoti apie veiksmingas emisiju valdymo priemones. Apsiribojant tik statistiniais duomenimis, susidaro įspūdis, kad Lietuvos galimybès (vis dar) beveik neribotos ir nereikalaujančios veiksmų. Aišku, taip ir yra, jei vertinimas atliekamas izoliuotoje aplinkoje (šiuo atveju konkrečios valstybès teritorijoje ir pagal tam tikrus ataskaitinius metus), tačiau šiltnamio dujų emisijos yra susijusios su klimato kaita, o tai - jau globali problema, nepavaldi politiniam, administraciniam, statistiniam suskirstymui.

Disertacija skirta miestų planavimo susiejimui su šiltnamio dujų emisijų valdymu, tačiau turi būti grindžiama juridiniais ịsipareigojimais. Darbą nukreipus tik ì ekologinę pusę, jis prarastų praktinio pritaikymo galimybę: siūlymas miestuose neišskirti šiltnamio dujų būtų skambus, tačiau (kol kas) neigyvendinamas. Darbe siūlomas kompromisinis variantas: remtis tarptautiniu 
mastu pripažintais dydžiais, tačiau atsiriboti nuo per daug palankių $1990 \mathrm{~m}$. duomenų. Taigi ne teigti, kad 2008-2012 m. Lietuvos „emisijos biudžetas“ yra 227,2 Mt $\mathrm{CO}_{2}$ ekvivalento, bet pažiūrèti, kaip, rengiant miestų bendruosius planus, būtų galima realiai emisijas sumažinti, pavyzdžiui, $8 \%$. Pasauliniame kontekste, ịvertinus vykstančius klimato kaitos procesus, emisijų mažinimas yra vienintelè logiška galimybè, kuri siūlomu atveju atitinka ES politiką, skatinančią atskirų šalių iniciatyvą kovoje su klimato kaita. ES pastebi, kad bendri veiksmai (ES ar tarptautiniu lygmeniu) yra efektyvesni, tačiau ,atskiros šalys privalo kuo mažiau sumažinti teršalų kiekį“" (EC 2011). Nacionaliniu lygiu toks tikslas taptų spręstinu, nes būtų panaikintos realiai neegzistuojančios emisijos „lubos“ ir iki jų esantis beveik dvigubas tarpas. Iš 2.4 pav. matoma, kad, skaičiuojant nuo JTBKKK ratifikavimo (1995 m.), faktinè Lietuvos emisija šokinejja intervale 39-51 imtinai, t. y. tik $13 \%$, todèl ir, pavyzdžiui, $8 \%$ Kioto protokolo reikalavimas tampa realesnis ir reikalaujantis aiškaus valdymo.

Pasiūlytą emisijų mažinimo (ne $1990 \mathrm{~m}$. biudžeto) idèją perkeliant ị miestų planavimo sriti, reikia parinkti skaičiuojamaji laikotarpi. Teisiškai planavimo rezultatus laiko požiūriu apibrèžia Teritorijų planavimo įstatymas: bendrojo plano sprendiniai galioja 10, o koncepcija - 20 metų. Rinktis koncepcijos laikotarpi komplikuota, nes jo metu susikirs dviejų planų sprendiniai, pareikalausiantys sudètingos priežiūros (monitoringo), be to, 20 metu - labai ilgas laiko tarpas net ir politiniame gyvenime (palyginus, Kioto protokolo I-asis periodas apima 5 m., II-asis - 8 m., ,Europa 2020“ strategija - 10 metu). Darbe siūloma remtis sprendinio galiojimo laikotarpiu ir tokiu atveju bendrojo plano pradejimo rengti data tampa emisiju atskaitos data, t. y. bendrojo plano sprendiniai turi būti tokie, kad 10 metų laikotarpiu užtikrintų atitinkamą emisijų sumažèjimą, lyginant su planavimo sąlygomis. Atskaitos datos susiejimas su planavimo procedūrų pradžia leidžia išvengti netikslingo (Lietuvos atveju) 1990 m. emisijų laikymosi. Labai tikètina, kad, rengiant bendraji planą, duotujų metu emisija dar nebus paviešinta, tokiu atveju siūloma remtis naujausia patvirtinta statistine informacija (dažniausiai 2 metų senumo). Lietuvos emisija iš principo yra gana tolygi, todèl esminio skirtumo dèl vienerių ar dvejų metų duomenu nesusidarytų. Skyrelyje jau buvo surašyti šiltnamio dujų emisijos mažinimo variantai, galimi miestu planavime: 1) remiantis Kioto protokolo I-uoju periodu (bent jau tol, kol nebus ratifikuotas naujas protokolas) arba 2) būsimojo protokolo projektinėmis vertèmis, arba 3) „Europa 2020“ iškeltu uždaviniu emisijas sumažinti $20 \%$, arba 4) „Europa 2020“ tikslais, tačiau diferencijuoti atsižvelgiant ị nacionalinius uždavinius (PTLS ir ne PTLS), arba 5) ịvertinant ES svarstomą galimybę emisijas mažinti ne $20 \%$, bet $30 \%$. Sutikus su pasiūlyta emisijų mažinimo kryptimi, 4 variantas tampa netinkamu, nes Lietuvai leistas $15 \%$ emisijos didinimas, todèl darbe siūloma ji pakeisti bendraeuropiniu ne PTLS sektoriaus tikslu - $10 \%$ mažesne emisija. Miestų planavimui ne PTLS 
sektorius iš principo tinkamas, nes apima tokius kertinius komponentus kaip būstas ir transportas. Tiksliai nustatyti, kuris iš mažinimo tikslų būtų įmanomas pasiekti bendrujų planų priemonėmis, kol kas nėra įmanoma, tam reikalingi skaičiavimai (detaliau žiūr. 3 skyrių). Vertinant iš ekologinès pusès, $30 \%$ emisijos sumažejjimas būtų patraukliausias, tačiau gali būti, kad (kol kas) jis būtų praktiškai Lietuvoje nepasiekiamas. Kita vertus, darbe siūlomas nuolatinis mažinimas nuo realių emisijų, todèl ir $8 \%$ sumažejjimas rodytų teigiamą poslinkị.

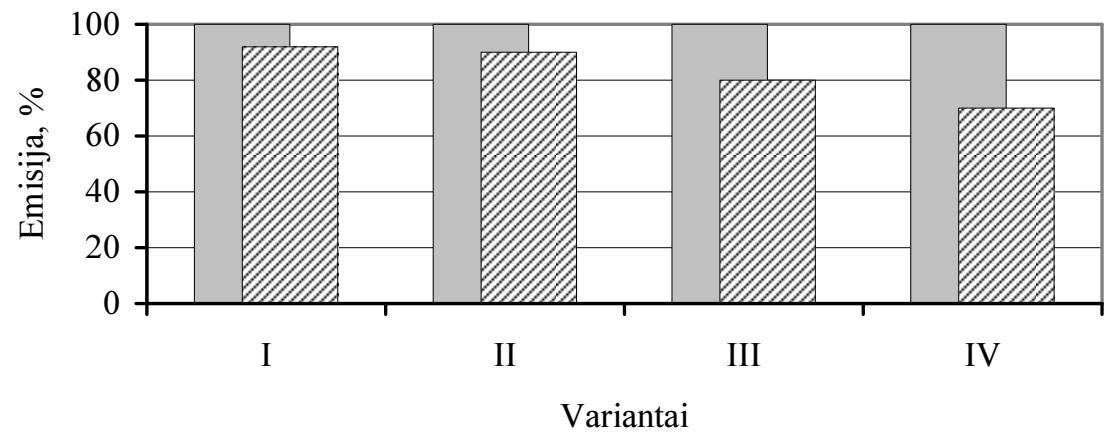

2.5 pav. Emisijų mažinimo variantai

Fig. 2.5. Emission reduction variants

Apibendrinant skyrelị, siūlomi emisijų mažinimo variantai grafiškai pateikti 2.5 paveiksle. Pilka spalva pažymèta sutartinių ataskaitinių (planavimo sąlygų išdavimo) metų emisija. Statistiniai duomenys turi būti naudojami iš oficialių duomenų bazių, todèl galimi 2-3 metų senumo duomenys. Užbrūkšniuotas stulpelis rodo bendrojo plano priemonèmis pasiektą emisijų sumažejimą per 10 metų. Pirmoji grupe rodo $8 \%$ sumažejimą pagal Kioto protokolo I-ajj periodą, antroji - $10 \%$ sumažejimą pagal ES ne PTLS sektoriu tikslą, trečioji - $20 \%$ sumažejimą pagal būsimo protokolo (po Kioto) vertes ir pagal „Europe 2020“

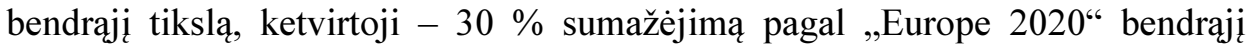
tikslą, esant atitinkamiems kitų šalių veiksmams. 


\subsection{Antrojo skyriaus išvados}

1. Antrajame skyriuje buvo pasiūlyta miesto ekologijos struktūra, atsižvelgiant i keturis aspektus: miesto ekologija turi būti apibrež̌ta konkrečiomis veiklos sritimis, kurios galètu igauti kiekybinę išraišką, be to, miesto ekologija turi būti vertinama platesniame kontekste, o siūloma struktūra turi būti valdoma miestų bendruosiuose planuose galimomis priemonèmis.

2. Siekiant kompleksinio suvokimo, pasiūlytame modelyje vengiama dirbtinès takoskyros, t. y. miestuose ir dèl miestų procesų vykstančius reiškinius siūloma vertinti kartu su žmonèmis, juos traktuojant kaip lygiaverčius sistemos komponentus (nehierarchinè pozicija).

3. Siūlomas miesto ekologijos modelis sudarytas iš dviejų lygių: išorinio ir vidinio, priklausomai nuo poveikio krypties. Procesai, darantys itaką pasauliniu lygiu, priskiriami išorinei miesto ekologijai, o procesai, svarbūs tik tam tikroje konkrečioje vietoje - vidinei miesto ekologijai.

4. İvertinant bendrojo plano daugiatiksliškumą ir dèl to ribotas bendruju planu galimybes, darbe miesto ekologijos sąvoka tikslingai susiaurinta iki pagrindinių sričių, atmetamos sritys, kuriose daromas neigiamas, tačiau neesminis poveikis aplinkai. Siūlomoje miesto ekologijos struktūroje atrinkti tik tie ekologiniai parametrai, kurie yra arčiausiai ribinių verčių, todèl reikalaujantys neatidèliotinų korekcijų. Išorinę miesto ekologiją siūloma suvokti kaip klimato kaitos, konkrečiu atveju šiltnamio dujų emisijos valdymą atliekų ir energetikos sektoriuose, vidinę miesto ekologiją - kaip oro ir triukšminès taršos ribojimą.

5. Skyriuje nustatytos išorinès miesto ekologijos ribinès vertès. Ribos apibrèžtos remiantis tarptautiniais teisiškai įpareigojančiais susitarimais, juos pritaikant miestų planavimo specifikai. Siūlomas skaičiuojamasis laikotarpis susietas su bendrujų planų sprendinių galiojimu, t. y. apima 10 metų laikotarpi, ir yra numatyti keturi galimi emisijų mažinimo variantai nuo $8 \%$ iki $30 \%$. 


\section{Išorinès miesto ekologijos modelio praktinis pritaikymas}

Pirmame skyriuje buvo analizuotos dabartinių teisinių dokumentų spragos, vertinant ekologini bendrujų planų aspektą iš miestų planuotojų perspektyvos. Europiniu lygiu miestu planavimas nèra reguliuojamas, o nacionalinès normos apsiriboja reikalavimais, plačiau nedetalizuojant priemonių, tikslų ar konkrečių ivertinimo galimybių. Antrame skyriuje, remiantis statistine informacija, tarptautinių organizacijų ir darbo grupių publikacijomis, buvo pasiūlytas miesto ekologijos modelis, kuris būtų tinkamas (suprantamas) miestų planavimo specialistams ir sudarytu sąlygas valdyti pagrindines miestų ekologines problemas. Siekiant konstruktyvaus miestų ekologijos valdymo, modelis orientuotas i kiekybini vertinimą. Pripažinus, kad miestų įtaka pasauliniams ekologiniams procesams yra mažai tyrinèta, tolesnei analizei buvo pasirinkta būtent išorine miesto ekologija. Sudèliojus bendraji miesto ekologijos modeli, atsirado galimybę patikslinti darbo ribas (2.2 poskyris), nurodant tuos išorinès ekologijos komponentus, kurie gali būti tvarkomi (planuojami) bendrujų planų priemonèmis. Trečias skyrius, skirtas minètiems komponentams, detalizuojamas atliekų tvarkymo ir energetikos sektorių integravimo i miestų planavimą klausimas. Svarbiu aspektu laikomas šių sektorių emisijų susiejimas su tais parametrais, kurie yra ịprasti miestų planavime. Pasiūlytas skaičiavimo modelis leidžia turimomis priemonėmis įvertinti ir planuoti miesto išorinę ekologiją. Šio 
skyriaus tema publikuoti trys straipsniai (Staniūnas and Burinskienè 2011; Staniūnas et al. 2012; Staniūnas et al. 2013).

\subsection{Komunalinių atliekų sektoriaus integravimas i miestų planavimo ekologiją}

$2012 \mathrm{~m}$. miesto gyventojai Lietuvoje sudare beveik $70 \%$ visų gyventojų (LSD 2013), todèl komunalinių atliekų tvarkymo klausimas miestuose pradiniuose komunalinių atliekų susidarymo šaltiniuose - ypač aktualus, be to, miestas - pati efektyviausia atliekų tvarkymo vieta. Atliekų klasifikavimas skiriasi priklausomai nuo valstybès. Lietuvoje ,prie komunaliniu atlieku priskiriamos ne tik buityje susidarančios atliekos, bet ir i jas savo pobūdžiu ar sudètimi ir kiekiu panašios atliekos, susidarančios imonèse, įstaigose ir organizacijose“" (VSATP 2002).

Atlieku apskaitos duomenimis, 2009 metais visoje Lietuvoje susidare apie $5 \mathrm{mln}$. tonų atliekų, iš jų $1,2 \mathrm{mln}$. tonų komunalinių atliekų (apie $24 \%$ ) (VSATP 2002). Atliekas susiejus su žmoniu skaičiumi, gauta, kad $2006 \mathrm{~m}$. statistiniam Lietuvos gyventojui teko $361 \mathrm{~kg}$ komunalinių atlieku, o $2008 \mathrm{~m}$. šis skaičius padidejo iki $407 \mathrm{~kg}$ (Eurostat 2011b). Lyginant su kitomis Europos Sajungos valstybemis, Lietuvoje susidarantis komunalinių atlieku kiekis (kilogramais), tenkantis vienam žmogui per metus, palyginti nedidelis (3.1 pav.), tačiau esminè Lietuvos problema - atliekų šalinimo būdas. Iki 2000 metų Lietuvoje buvo virš 800 didesnių ir mažesnių sąvartynų, kurie netenkino aplinkosaugos reikalavimų ir kèlè grèsmę aplinkai. Atliekų šalinimas šiuose sąvartynuose nuo 2009 m. liepos 16 d. nutrauktas. Šiuo metu atliekos šalinamos vienuolikoje regioninių nepavojingujjų atliekų sąvartynų, atitinkančių aplinkos apsaugos ir visuomenès sveikatos saugos reikalavimus. Vis dèlto tai iš esmès nekeičia paties fakto: Lietuvoje didžioji dalis atliekų vis dar yra šalinama sąvartynuose, pavyzdžiui, 2009 metais sąvartynuose pašalinta beveik $91 \%$ komunalinių atliekų (VSATP 2002) (palyginti: Danija ir Liuksemburgas daugiau kaip $50 \%$ atlieku sudegina (UNEP 2010)).

Pasauliniu mastu pagrindinè ekologinè problema, susijusi su sąvartynais, yra sąvartyno dujos, kurios priklauso šiltnamio efektą sukeliančioms dujoms. Atlikti tyrimai rodo, kad sąvartyno dujų formavimasis ir dujų sudetis priklauso nuo ìvairių faktorių, tokių kaip atliekų saugojimo būdas, atliekų sudètis, temperatūra, sąvartyno amžius, metų sezonas ir paros laikas (Park and Shin 2001; U. S. EPA 2006; Manfredi et al. 2009), todèl, norint žinoti tikslią dujų sudetį ir kiekį, reikalingi vietos sąvartyno tyrimai (Jha et al. 2008). Kita vertus, kalbant apie sąvartyno dujas miestų planavimo kontekste, reikètų atsižvelgti i miestų planuotojų darbo mastelius ir tikslumą - planuojamos didelès teritorijos, 
vertinama daug aspektų vienu metu, todèl miestų planuotojams pakaktų apibendrintos informacijos. Apibendrinta informacija turètų dar vieną privalumą - ji būtų greitai prieinama, o tai svarbu, turint omenyje, kad miestų planams parengti skiriamas ribotas laikotarpis. Darbe remiamasi nuostata, kad vertinamos tos komunalinès atliekos, kurios išmetamos dabar, t. y. žinoma atliekų sudetis, ir dujų formavimosi procesai vyks pagal dabar žinomus sąvartyno dujų formavosi etapus.

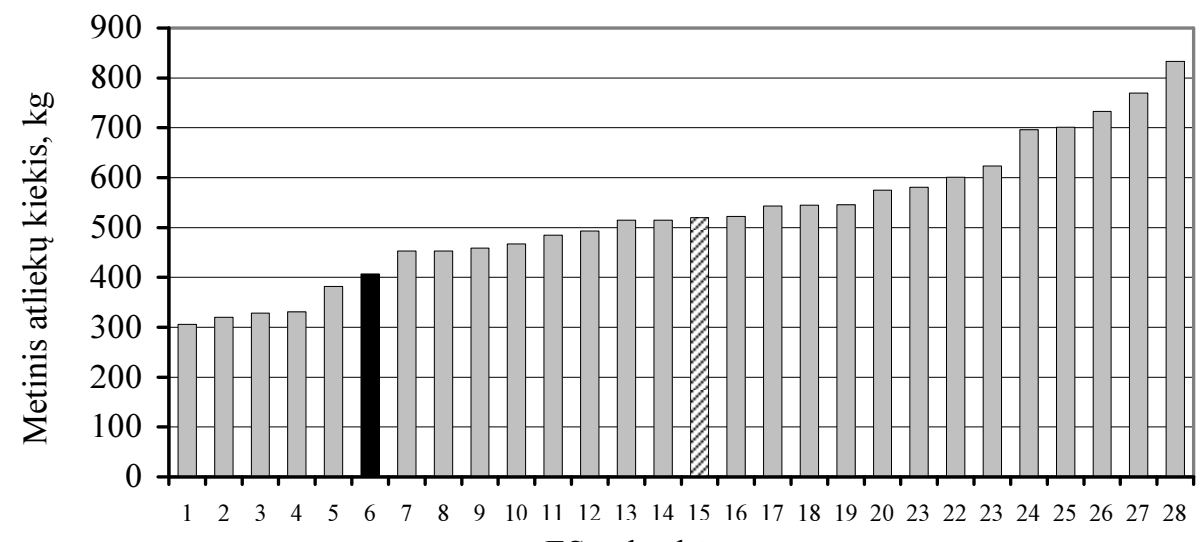

ES valstybès

3.1 pav. Metinis komunalinių atliekų kiekis kg 1 gyventojui $2008 \mathrm{~m}$.

Fig. 3.1. Municipal waste generation (kg per capita) in 2008

Pastabos: Duomenys pagal Eurostat 2011b. 1 - Čekija, 2 - Lenkija, 3 - Slovakija, 4 - Latvija, 5 - Rumunija, 6 - Lietuva, 7 - Graikija, 8 - Vengrija, 9 - Slovenija, 10 - Bulgarija, 11 - Portugalija, 12 - Belgija, 13 - Estija, 14 - Švedija, 15 - ES-27, 16 - Suomija, 17 - Prancūzija, 18 - Italija, 19 - Didžioji Britanija, 20 - Ispanija, 21 - Vokietija, 22 - Austrija, 23 - Olandija, 24 - Malta, 25 - Liuksemburgas, 26 - Airija, 27 - Kipras, 28 - Danija

Sąvartyno dujos formuojasi irimo proceso metu, kurio metu išsiskiria metanas $\left(\mathrm{CH}_{4}\right)$ ir anglies dioksidas $\left(\mathrm{CO}_{2}\right)$. Metanas sudaro apie 50-60\%, o anglies dioksidas apie $-40-50 \%$ visų susiformavusių sąvartyno dujų (U. S. EPA 2000; Verma 2002; Themelis and Ulloa 2007; Manfredi 2009). Yra iprasta anglies dioksido emisiją skaidyti į dvi dalis: biogeninę ir antropogeninę anglies dioksido emisiją. Skaičiavimuose, kurie susiję su klimato atšilimu, naudojama tik antropogeninè emisija, nes biogeninè dalis klimato atšilimo atžvilgiu laikoma „neutralia“ (U. S. EPA 2008a; Gentil et al. 2009; Scheutz et al. 2009). Pavyzdžiui, yrant medžiui, $\mathfrak{i}$ aplinką išsiskiria tas pats anglies dioksidas, kuris buvo absorbuotas medžio augimo laikotarpiu, todèl šis anglies dioksidas nedidina bendros anglies dioksido koncentracijos atmosferoje. Anglies dioksido 
kiekis, išsiskyręs iš, pavyzdžiui, plastiko ar gumos, skiriamas klimato atšilimą skatinančių dujų tipui, nes nèra gamtinès kilmès ir didina bendrą anglies dioksido koncentraciją. Sąvartyno dujos formuojasi mikrobiologinio irimo proceso metu, t. y. pirmiausia yrant gamtinès kilmès atliekoms, todèl išsiskyręs anglies dioksidas priskiriamas „neutraliam“ anglies dioksido kiekiui. Vadinasi, klimato atšilimą daugiausia lemia metano emisija. Metano dujų, priklausančių komunalinių atliekų sektoriui Lietuvoje, pasiskirstymo schema pateikta 3.2 paveiksle.

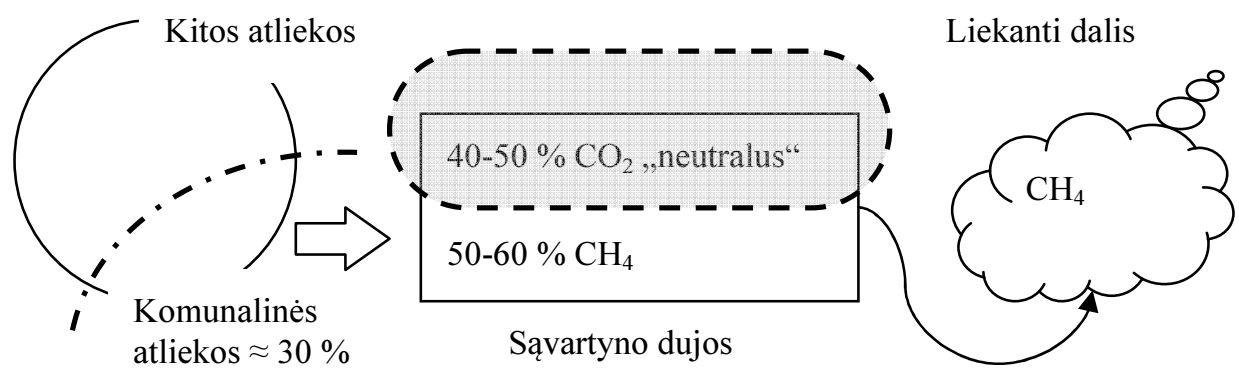

3.2 pav. Metano dujų dalis komunalinių atliekų sektoriuje Lietuvoje

Fig. 3.2. Methane share within municipal solid waste sector in Lithuania

Egzistuoja skirtingi metodai, padedantys nustatyti išsiskiriančio metano kiekius. Pirmajai grupei galima skirti skaičiavimo metodus, kurie nurodo gaunamą metano kieki per tam tikrą laiko tarpą, kuris savo ruožtu taip pat skirtingas, o antrajai grupei priklausytų matavimai, apibrezžiantys sumini dujų kieki, nepriklausomai nuo laiko tarpo, kitaip sakant, nurodantys visą išsiskirsiančių dujų kieki iki visiškai suyrant atliekoms. Renkantis miestų planavimui tinkamą metodą, svarbūs keli aspektai, kuriuos reikètų ịvertinti. Atliekas atvežus i sąvartyną, dujos prasideda formuotis tik po kurio laiko, didesni kiekiai išsiskiria maždaug po vienerių metų, o dujų formavimosi pikas pasiekiamas tik 5-7 metais. Po 20 metų beveik visos dujos būna susigeneravusios, tačiau maži jų kiekai gali išsiskirti po 50 ir daugiau metų. 2.3 poskyryje buvo paaiškinta, kad, derinantis prie miestų planavimo praktikos, skaičiuojamasis laikotarpis turètų apimti 10 metų, tačiau tik šio laikotarpio skaičiavimai būtų nekorektiški, nes parodytų tik dalị realaus bendro kiekio. Tinkamesnis ir tikslesnis būtų antrasis metodas - nustatantis dujų kieki iki visiškai suyrant atliekoms. Šiuo atveju bendruoju planu būtų sprendžiama visa problema, o sprendimas nenukeliamas $i$ ateitị, maža to, problema būtų sprendžiama greičiau, nei iškils visas pavojus.

Apskritai suminis sąvartyno dujų kiekis varijuoja nuo $100 \mathrm{iki} 200 \mathrm{~m}^{3}$ iš vienos tonos komunalinių atliekų, priklausomai nuo atliekų sudetties ir laiko 
tarpo (Manfredi 2009; Verma 2002), tačiau konservatyvesniuose skaičiavimuose nurodytos mažesnes reikšmes: $50 \mathrm{~m}^{3}$ (Themelis and Ulloa 2007), $86 \mathrm{~m}^{3}$ (Manfredi 2009). Atitinkamai metano kiekis (50-60\%) būtų nuo 25 iki $120 \mathrm{~m}^{3}$ iš vienos tonos komunalinių atliekų. JAV Aplinkos apsaugos agentūra nurodo, kad metano emisija gali dar stipriau varijuoti nuo $6,2 \mathrm{iki} 270 \mathrm{~m}^{3}$ iš vienos tonos komunalinių atliekų, todèl skaičiavimams siūlomas dydis $-100 \mathrm{~m}^{3}$, teigiama, kad jis geriausiai suderina praktiškai išmatuotas ir skaičiuotinas vertes (U. S. EPA 2008b). Lietuvoje néra apibendrintų statistinių duomenų apie metano dujų formavimąsi sąvartynuose, todèl darbe naudojama minèta U. S. EPA informacija, t. y. $100 \mathrm{~m}^{3}$ iš vienos tonos komunalinių atliekų. Kita vertus, jei ateityje Lietuvoje būtų atlikti reikalingi tyrimai, nebūtų sunku ịvesti atitinkamas korekcijas.

Metano emisiją siejant su miestų planavimu, reikètų atkreipti dèmesị i dvi pastabas: duomenų bendrumą ir palyginimo galimybę. Skaičiavimams siūloma naudoti tik tuos statistinius duomenis, kurie yra gauti apibendrinus visos Lietuvos duomenis. Gali būti, kad konkrečiame sąvartyne atlikti tyrimai duotų pati tiksliausią rezultatą, tačiau ištirti vietos sąvartynus kiekvieno miesto bendrojo plano rengimo metu labai komplikuota. Praktiškiau remtis apibendrintais duomenimis, kurie yra tinkami nacionaliniu lygmeniu. Kaip jau buvo minèta, $2008 \mathrm{~m}$. Lietuvoje vienam asmeniui teko $407 \mathrm{~kg}$ komunalinių atliekų (Eurostat 2011b). Galutini metano kiekị (išreikštą $\mathrm{m}^{3}$ ), iki visiškai suirs atliekos, galima suskaičiuoti pagal (3.1) formulę:

$$
K_{1 m}=M \frac{W}{1000},
$$

čia $M$ reiškia vidutini išsiskiriantị metano kieki (straipsnyje priimta $100 \mathrm{~m}^{3}$ iš vienos tonos) ir $W$ - vidutinį atliekų kiekị, tenkantị vienam gyventojui (darbe $407 \mathrm{~kg}$ ). Tokiu atveju $K_{l m}$ parodys sumini (galutini) metano kieki $\mathrm{m}^{3}$, kuris išsiskirs iš komunalinių atliekų, kurias vienas statistinis žmogus išmeta per vienerius metus.

Šiltnamio dujos išbūna atmosferoje skirtingą laiko tarpą ir sugeria skirtingą šilumos kiekị, todèl tos dujos, kurios išbūna ilgiausiai ir sugeria daugiausiai šilumos, yra pačios pavojingiausios. Kad būtų i̇manomas skirtingų dujų palyginimas, dažniausiai naudojamas pasaulinio atšilimo potencialo (Global Worming Potential (GWP)) indeksas. Indeksas parodo, kiek tam tikro laiko ribose $1 \mathrm{~kg}$ konkrečių dujų radiacinè galia skiriasi nuo $1 \mathrm{~kg}$ anglies dioksido radiacinès galios (Forster et al. 2007). GWP reikšmé yra paprastas ir lengvai suprantamas skaičius, todèl šis indeksas ypač dažnai sutinkamas politiniuose, tarptautiniuose dokumentuose, pavyzdžiui, IPCC ataskaitose. İdomu tai, kad nors metanas išbūna atmosferoje sąlyginai trumpą laiko tarpą, dèl specifinių pokyčių (OH koncentracijoje) netiesioginè metano įtaka jaučiama kur kas ilgesni 
laiko tarpą (Forster et al. 2007). Dažniausiai GWP pateikiamas vertinant 100 metu perspektyvoje, tačiau kiti laiko intervalai taip pat galimi, tipiniai laiko intervalai yra 20, 100 ir 500 metų. Darbe siūlomas skaičiuojamasis laikotarpis (10 metų) nepatenka i minètus laikotarpius, o GWP kinta nenuosekliai, todèl paprastos interpoliacijos būdu apskaičiuotas metano GWP po 10 metų būtų netikslus. 20 metu periodas yra artimiausias ir jis sutampa su koncepcijos galiojimo laiku, be to, tai yra vienas iš standartinių laikotarpių, todèl, esant poreikiui, leidžia išplèsti palyginimo galimybes iki tarptautinio lygmens. Remiantis IPCC duomenimis (Forster et al. 2007), metano GWP 20 metu laikotarpyje yra 72, tai reiškia, kad $1 \mathrm{~kg}$ metano atitinka $72 \mathrm{~kg} \mathrm{CO}_{2}$ ekvivalento. Formulèje (3.1) rezultatas yra pateikiamas kubiniais metrais, todèl, norint $\mathrm{i}$ skaičiavimus itraukti GWP indeksą, rezultatą reikia konvertuoti i svorio vienetus. U. S. EPA yra parengusi interaktyvų vienetų konverteri, kuriuo remiamasi darbe: pagal skaičiuoklę $1 \mathrm{~m}^{3}$ metano sveria $0,6802 \mathrm{~kg}$ (U. S. EPA 2012). Atitinkamai pakoregavus (3.1) formulę gaunama (3.2) formule su GWP indeksu:

$$
K_{2 m}=M \frac{W}{1000} T I_{G W P}=K_{1 m} T I_{G W P},
$$

čia $T$ yra konvertavimo koeficientas, leidžiantis metano kieki kubiniais metrais perskaičiuoti ị kilogramus ( $T$ yra $0,6802 \mathrm{~kg}$ ) ir $I_{G W P}-$ metano GWP indeksas tam tikru laiko periodu (konkrečiu atveju 72). $K_{2 m}$ parodys sumini metano kieki kaip ir formulèje (3.1), tačiau formulès (3.2) rezultatas išreiškiamas $\mathrm{kg} \mathrm{CO}_{2}$ ekvivalento.

Remiantis (3.2) formule, apskaičiuota, kad statistinis lietuvis $2008 \mathrm{~m}$. išmetė tokị kieki komunalinių atliekų, kuriam visiškai suirus, išsiskirs toks metano dujų kiekis, kuris atitiks vidutiniškai 1993 kg CO 2 ekvivalento (vertinant 20 metų perspektyvoje). Apskaičiuotas skaičius gautas naudojant bendravalstybinius duomenis, todèl rezultatas gali būti vienodai taikomas bet kuriame Lietuvos mieste. Gyventojų skaičius - planavimo praktikoje vartojamas parametras (2.1 lentelè, I.4 parametras), o siūlomas skaičiavimo būdas paprastas, todèl atitinka miestų planuotojų keliamus reikalavimus: apibendrinti duomenys ir greitas rezultatas. Gyventojų skaičių padauginus iš 1993, galima sužinoti bendrą $\mathrm{CO}_{2}$ ekvivalento kieki kilogramais, kuris bus generuojamas kasmet, susidarantis kiekis bus didelis, todèl patogiau skaičiuoti ne kilogramais, o sustambinti iki tonų ((3.3) formulè):

$$
K_{3 m}=\frac{K_{2 m}}{1000} N,
$$

čia $N$-gyventojų skaičius mieste. 
Vis dèlto yra trys pastabos, ì kurias reikètų atkreipti dėmesị. Pirma, komunalinių atliekų kiekis yra kintantis dydis, todèl šiuos duomenis derètu po tam tikro laiko (pvz., ipusèjus sprendiniu galiojimo laikotarpiui) patikslinti. Antra, komunalinių atliekų kiekis parodo kasmetinį atliekų kiekį, todèl faktiškai bendrojo plano sprendiniu galiojimo metu (per 10 metų) susidarytų maždaug 10 kartų didesnis kiekis (3.4) formulè. Trečia, susidarantys metano kiekiai yra suskaičiuoti remiantis užsienio praktika, todèl vietos (Lietuvos) tyrimai užtikrintų tikslesnius siūlomo skaičiavimo rezultatus.

$$
\sum K=10 K_{3 m} \text {. }
$$

Sužinojus bendrojo plano sprendinių galiojimo metu susidarysiančią emisiją dèl komunalinių atliekų, reikalingas metodas, leidžiantis bendrojo plano galimybių ribose sumažinti neigiamas ekologines pasekmes. Viena iš populiariausių kompensavimo priemonių, susijusių su klimato atšilimu, yra medžių sodinimas. Tam didelę įtaką padare Kioto protokolas, kuriuo pasiūlyta dali anglies dioksido emisijos kompensuoti medžiais, be to, miestuose želdynu masyvai prisidètų prie mikroklimato gerinimo, atliktų vizualinę, estetinę funkcijas, ne mažiau svarbu ir tai, kad sodinti medžius techniškai paprasta ir nebrangu. Miesto bendrajame plane, remiantis 1.3 poskyryje atrinktais kiekybiniais rodikliais, reikalingą želdynų kiekį siūloma priskirti II grupès rodikliams, tiksliau, II.2 (žemès naudojimo būdai) arba II.4 (bendrojo naudojimo želdynai), arba II.5 (apsauginiai želdynai). Prieš pateikiant tolesnius skaičiavimus, svarbu pabrèžti, kad (atsiribojus nuo miestų planavimo) medžių sodinimas turi esmini trūkumą: ši priemonè tẻra kompensacija tiesiogine žodžio prasme, nes pasodinti medžiai gali absorbuoti būsimą emisiją, bet neturi jokios realios itakos komunalinių atlieku kiekio mažinimui. Pirminis atliekų kiekio mažinimas (vartojimo ịpročių keitimas) yra neabejotinai pati efektyviausias priemonè, tačiau jis nèra pavaldus miestų planavimui, todèl darbe nèra analizuojamas.

Tyrimais užfiksuotos medžių anglies dioksido sekvestracijos galimybès stipriai varijuoja nuo 0,5 iki $2,3 \mathrm{~kg}$ iš vieno kvadratinio metro, sodinant medžius iš naujo ir nuo 0,3 iki $1,9 \mathrm{~kg}$ - atsodinant (iškirstus ar pan.) medžius (Gorte 2009), tačiau apskritai yra laikoma, kad vienas medis per savo gyvenimą (100 metu) absorbuoja 1 toną anglies dioksido. Renkantis medžių sodinimą kaip anglies dioksido emisijos kompensavimo priemonę, skaičiuojamasis laikotarpis yra svarbus, nes nuo jo priklauso sugertas anglies dioksido kiekis. Garantuoti, kad medis augs 100 metų ir tuo laikotarpiu nebus nukirstas, jo neužpuls kenkejai ar miške neįvyks gaisras, yra rizikinga, todèl trumpesnis laikotarpis būtų tinkamesnis. Darbe pasirinktas atsargus sprendimas - per pusę trumpesnis laikas (50 metu), kurio metu sąlyginis medis atitinkamai absorbuotu 0,5 tonos anglies dioksido. Remiantis (3.2) formule, statistinis gyventojas išmeta tokị komunalinių 
atliekų kiekį, kurio žala lygi 1,99 tonos $\mathrm{CO}_{2}$ ekvivalento, per 10 metų bus išmestas maždaug 10 kartų didesnis kiekis, todèl bendrojo plano sprendinių galiojimo metu suminè emisija bus 19,9 tonos $\mathrm{CO}_{2}$ ekvivalento. Šiam dujų kiekiui absorbuoti reikès apie 40 medžių, o jiems skirta žemé turètų būti rezervuota miestų bendrujų planų rengimo etape.

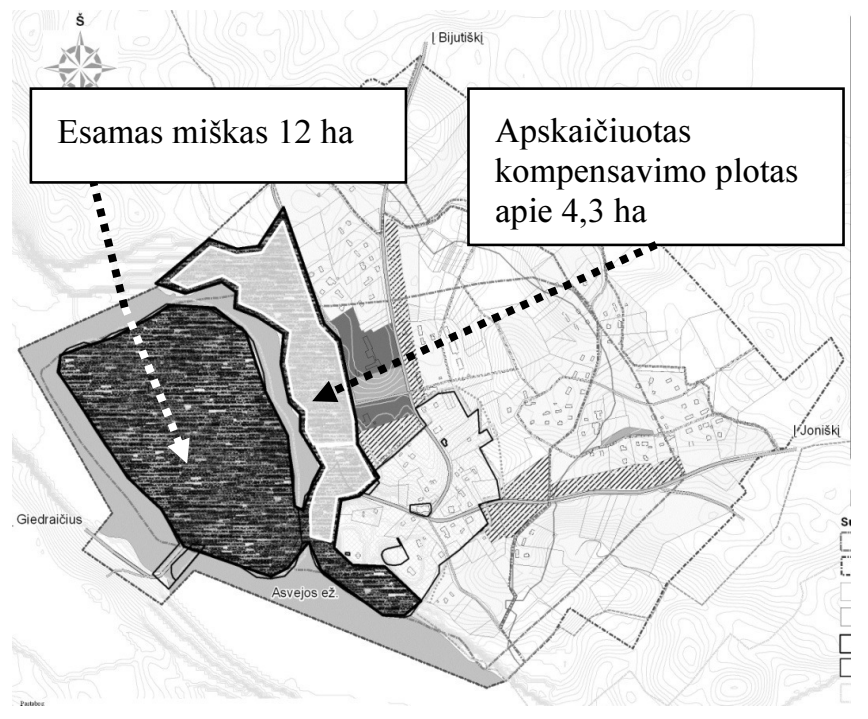

3.3 pav. Kompensavimo plotas Dubingiuose

Fig. 3.3. Compensation area in Dubingiai

Želdynu istatymas ir susiję poịstatyminiai aktai pateikia želdynų klasifikaciją, pasiekiamumo spindulius, nustato minimalų reikalingą želdynų plotą ir pan. Teisinius dokumentus galima būtų nesunkiai pertvarkyti taip, kad juose atsirastų aptartas kompensavimo medžiais mechanizmas. Želdynų plotų reikalavimai nurodyti kvadratiniais metrais vienam asmeniui, todèl reikia atitinkamai perskaičiuoti, kiek ploto pareikalautų 40 medžių. Medžių tankis priklauso nuo medžių rūšies, pradinio sodinimo tankumo ir medžių auginimo tikslo, todèl Lietuvoje medžių sodinimo tankumas varijuoja nuo 1500 vienetų (drebulè) iki 5000 vienetų (pušis) viename hektare (Miško atkūrimo ir įveisimo nuostatai 2008). Disertacijoje buvo pasirinktas „atsargesnis“ (retesnis) medelių tankis: 2000 vienetų viename hektare, todèl atitinkamai 40 medžių pareikalautų 200 kvadratinių metrų žemès. Šio ploto pakaktų, kad būtų panaikinta (absorbuota) emisija, gauta iš vieno gyventojo komunalinių atliekų, išmestų per 10 metų (ịvertinus visą dujų kieki iki galutinio atliekų suirimo). Jei bendruoju 
planu būtų norima nurodyti medžių sodinimą etapais, tuomet kasmetinè apželdinimo norma būtų $20 \mathrm{~m}^{2}$ vienam gyventojui.

Aptartas kompensavimo metodas buvo išbandytas remiantis (mažo) Dubingių miestelio ir (didelio) Telšių miesto bendraisiais planais. Bendrujų plano rengejas - Teritorijų planavimo mokslo institutas, toliau pateikti statistiniai duomenys yra gauti iš rengejjo. Dubingiai - miestelis Molètų rajono pietuose, $20 \mathrm{~km}$ i pietus nuo Molètu ir apie $45 \mathrm{~km}$ nuo Vilniaus. Dubingiu miestelio bendrasis planas rengtas $2009 \mathrm{~m}$. $-2010 \mathrm{~m}$., dabartinis miestelio plotas apie 90 ha. Dubingiu seniūnijos duomenimis, 2009 m. Dubingiuose gyveno 215 gyventojų. Remiantis (3.4) formule, 215 gyventoju ,ppagamintų“ apie 4300 tonų $\mathrm{CO}_{2}$ ekvivalento, emisijai kompensuoti reikètų apie 8600 medžių, medžiams būtų reikalingas ne mažesnis kaip 4,3 ha plotas (3.3 pav.)

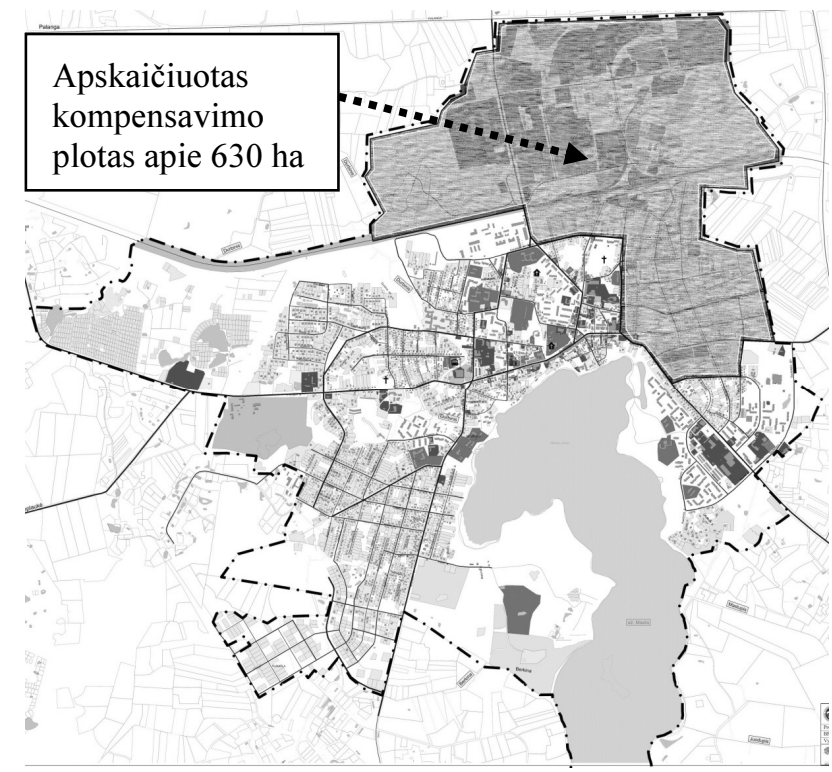

3.4 pav. Kompensavimo plotas Telšiuose

Fig. 3.4. Compensation area in Telšiai

Šiuo metu Dubingiuose yra daugiau kaip 12 ha brandaus miško, todèl papildomas medžių sodinimas nebūtų reikalingas. Tie patys skaičiavimai taikyti Telšiams atskleidè kitokius rezultatus. Telšių plotas yra maždaug 20 kartų didesnis, jame gyvena apie 31,6 tūkst. gyventojų. Miesto gyventojai per $10 \mathrm{~m}$. „pagamintü“ apie 628,8 tūkst. tonų $\mathrm{CO}_{2}$ ekvivalento, emisijai kompensuoti reikètų apie 1257,7 tūkst. medžių, medžiams reikalingas apie 630 ha plotas 
(3.4 pav.). Šiuo metu Telšiuose želdynams skirti plotai užima apie 200 ha, o (skirtingai nuo Dubingių) reikalingas net tris kartus didesnis plotas.

Akivaizdu, kad kompensavimo medžiais mechanizmas miestų teritorijose galimas esant specifinėms sąlygoms (pvz., maži miesteliai, turintys didelius želdynų plotus), kurios sunkiai i̇manomos didesniuose ir dideliuose miestuose. Tokiais atvejais galimi sprendimai - reikalingų želdynams plotų skyrimas už miesto teritorijų, nes konkreti medžių augimo vieta nèra svarbi. Vertinant platesniame kontekste, medžiams reikalingos teritorijos galètų būti numatytos LR bendrajame plane, jei tam būtų sukurti tinkami teisiniai susitarimai ir monitoringo sistema. $2012 \mathrm{~m}$. Lietuvoje buvo 2,17 mln. ha miško žemès ploto (LR AM 2012), o, kompensuojant visų respublikos gyventojų (nepilnai $3 \mathrm{mln}$.) emisiją, reikalingas plotas būtų 60 tūkst. ha, t. y. apie $3 \%$ miškų žemès, todèl būtų ịmanomi visi 2.3 poskyryje aptarti emisijų mažinimo scenarijai.

Kaip buvo minèta, medžių sodinimas yra kompensavimo priemonè, nereikalaujanti esminių pokyčių miesto valdyme, bet drauge ir neatnešanti naudos miestui. Remiantis ES valstybėse (pvz., Danijoje, Austrijoje) populiaria praktika, galimi sprendimai būtų atliekų deginimas specialiose stotyse arba sąvartyno dujų surinkimas pačiuose sąvartynuose. Degimo proceso metu, kaip ir atliekų irimo metu, išsiskiria anglies dioksidas, tačiau yra du svarbūs skirtumai. Pirma, atliekų deginimas labai sumažintų sąvartynams reikalingus plotus. Antra, atliekų deginimas - kontroliuojamas dirbtinis procesas, todèl išsiskyrusi šiluminè energija gali būti panaudota statinių šildymui arba paversta elektra. Elektros gamybos efektyvumas varijuoja 18-26\% ribose (Fruergaard et al. 2009) ir gali siekti 25-35\%, jei sąvartyno dujos deginamos dujų varikliuose, kurie generuoja tiek elektrą, tiek šilumą (Manfredi et al. 2009). Biodujų vertimas šiluma yra dar efektyvesnis ir siekia 40-50 \% (Fruergaard et al. 2009). Iš principo surinktų atliekų deginimas specialiose stotyse yra naudingesnis nei sąvartynuose: degimo procesą lengviau valdyti, energijos atgavimas yra efektyvesnis ir - ypač svarbu iš ekologinès pusès - gaunama mažesnè emisija (pirmiausia dèl to, kad nesusidaro metano dujos) (Kaplan et al. 2009). Atliekų deginimo ekologinè nauda priklauso nuo to, koks pradinis šilumos šaltinis yra pakeičiamas. $2011 \mathrm{~m}$. Lietuvoje centralizuotai tiekiamos šilumos gamybai reikalinga energija beveik išimtinai buvo gaunama iš naftos: 73,1 \% - gamtinès dujos ir 2,7 \% - mazutas (LSTA 2012), todèl akivaizdu, kad atliekų deginimas ir energijos panaudojimas šildymui Lietuvai būtų prasmingas.

Nepaisant to, kad biodujų vertimas šiluma yra beveik dvigubai efektyvesnis procesas nei elektros gamyba, jis nèra labai plačiai paplitęs. Problemą suponuoja atstumas tarp šilumos šaltinio ir šilumos vartotojų: kuo toliau reikia transportuoti šilumą, tuo didesni nuostoliai, o šalia atliekų deginimo stočių dažniausiai nebūna stambaus šilumos vartotojo. Kita vertus, dalis generuotos šilumos gali būti panaudota pačioje atliekų deginimo stotyje arba perduota tam tikrą (ribotą) 
atstumą skirstomaisiais tinklais. Atstumas iki vartotojų yra vienas iš svarbiausių efektyvumą laiduojančių veiksnių, todèl jis turètų būti ịvertintas miesto bendrojo plano rengimo metu. Remiantis užsienio patirtimi (Richarz et al. 2007), centrinis šildymas yra prasmingas tada, jei galutiniai vartotojai yra nutole 5-10 km spinduliu nuo šilumos gamintojo (šiuo atveju atliekų deginimo stoties). Mažas atstumas iki atliekų deginimo stoties naudingas ne tik dèl mažesnių generuojamos šilumos transportavimo nuostoliu, bet ir iš atliekų gabenimo ị stotị pusès. Apskritai ivvertinant logistikos problemas, kaštus ir šiuolaikinių technologijų (filtrų) galimybes, būtų tikslinga atliekų deginimo stotị projektuoti miesto teritorijoje. Vienas sèkmingiausių pavyzdžių yra Vienoje (Austrija) veikianti Spittelau atliekų deginimo gamykla, kuri yra netgi tapusi turistų lankomu objektu. Stotis buvo pastatyta tam, kad aprūpintų šiluma naujai statomą ligoninę, esančią už $2 \mathrm{~km}$, o šiandien Spittelau yra antroji pagal šilumos gamybos pajègumą jègainè Vienoje, iš viso pagaminanti $460 \mathrm{MW}$ (Wien Energie 2012). Lietuvoje situacija yra kardinaliai priešinga: $2013 \mathrm{~m}$. pradžioje nebuvo nei vienos pilnai funkcionuojančios (dirbančios neeksperimentiniais, bandomaisiais tikslais / režimu, pakankamai didelès ir prijungtos prie šilumos tinklų) atliekų deginimo stoties, be to, viešoji nuomonè vis dar nepalaiko panašių iniciatyvų. Vienas iš pažangiausių projektų - Klaipėdos termofikaciné jègainè, deginsianti komunalines atliekas, sulaukè be galo didelio visuomenès pasipriešinimo, pasiekusio net žiniasklaidą (Delfi 2013a).

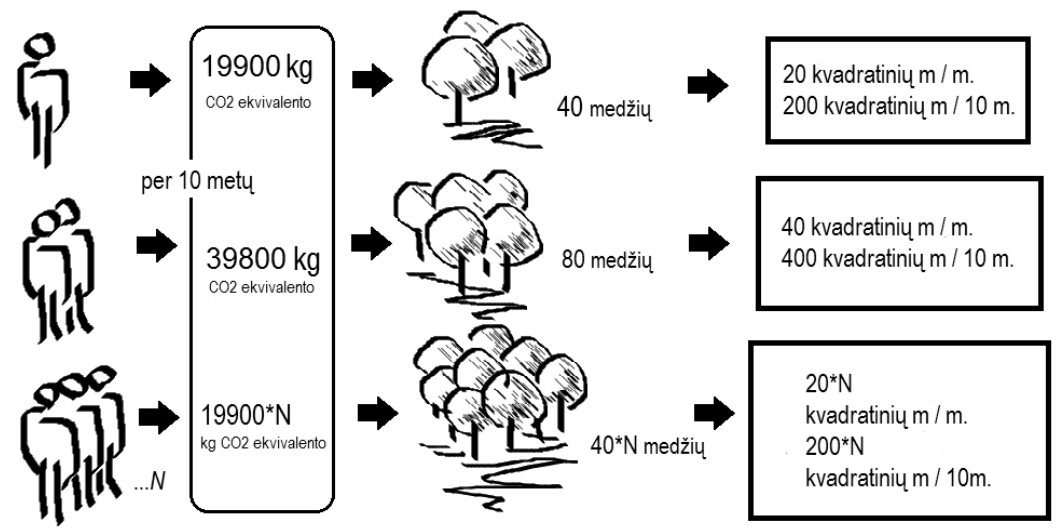

3.5 pav. Komunalinių atliekų sektoriaus žalos kompensavimas

Fig. 3.5. Compensation of municipal solid waste damage

3.1 poskyris buvo skirtas aprašyti komunalinių atliekų sektoriaus įtraukimo i miestų planavimą galimybèms. Remiantis pasiūlytomis formulèmis, buvo 
suskaičiuota emisija, susijusi su statistinio žmogaus išmestų komunalinių atliekų kiekiu per 10 metų (Lietuvoje ji yra vidutiniškai 19,9 tonos $\mathrm{CO}_{2}$ ekvivalento). Miestų planavime neigiamas emisijų poveikis gali būti sprendžiamas rezervuojant teritorijas parkams ir miškams. Didesniems miestams reikalingos papildomos teritorijos, esančios už miesto administracinių ribų. Siekiant ,panaikinti“" suskaičiuotą vidutinio žmogaus emisiją, medžiais reikia užsodinti 200 kvadratinių metrų plotą. Grafiškai kompensavimo mechanizmas pavaizduotas 3.5 paveiksle. Siekiant naudos miestui, buvo aptarti atliekų deginimo privalumai, jei ateityje Lietuvoje atsirastų realios sąlygos atlieku deginimo stoties statybai, tai ji efektyviai galètu šiluma aprūpinti teritorijas, esančias 5-10 km nuo stoties. Naudingiausią būtų atliekų deginimo stoties vietą numatyti bendrojo plano rengimo metu ir jai skirti vietą miesto administracinèse ribose, galimai arčiausiai vartotojų.

\subsection{Energetikos sektoriaus integravimas ị miestų planavimo ekologiją}

Lietuvos statistikos departamento renkamoje ir pateikiamoje informacijoje energetikos sektorius apibrèžiamas (supaprastintai) kaip atskiras sektorius, gaminantis energiją (pvz., žalios naftos gavyba, elektros, dujų tiekimas ir pan.), ir šiai grupei, pvz., privatūs energijos vartotojai ar transporto sektorius nepriskiriami, nes minètieji sektoriai (dažniausiai) vartoja, o ne gamina energiją. Atsižvelgiant $\mathfrak{i}$ darbo tematiką ir remiantis 2.2 poskyryje pateikta informacija, energetikos sektorius suskirstytas pagal energijos suvartojimo analizę, t. y. akcentuojama ne energijos gamyba, o priešingai - jos suvartojimas. Atitinkamai 3.2 poskyris skirtas energijos suvartojimo (ne gamybos) analizuojamose srityse integravimui ị miestų planavimo ekologiją.

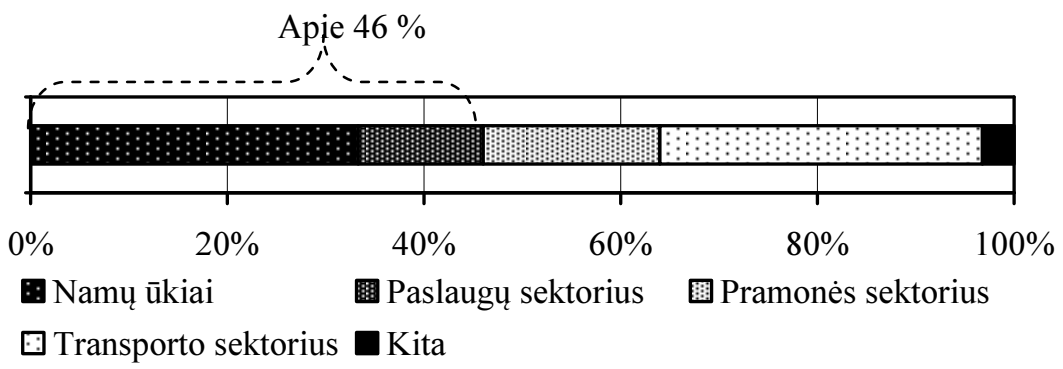

3.6 pav. Kuro ir energijos suvartojimas Lietuvoje $2010 \mathrm{~m}$.

Fig. 3.6. The fuel and energy consumption in Lithuania in 2010 
2010 m. bendrosios vidaus energijos sąnaudos Lietuvoje buvo 7042,5 tūkst. tonų naftos ekvivalento, galutinis suvartojimas sudare 4756,3 tūkst. tonų naftos ekvivalento, iš jo namų ūkiuose buvo suvartota $33,3 \%$, paslaugu sektoriuje (prekybos, švietimo, komercinių ir kitų imonių patalpų šildymas ir apšvietimas) - 12,7 \%, pramonès sektoriuje (kasyba, apdirbamoji gamyba) $18,0 \%$ ir transporto sektoriuje - 32,8 \% (3.6 pav.) (LSD 2011a). Remiantis statistine informacija, didžiausi energijos vartotojai yra namų ūkiai ir transporto sektorius, pramonès sektorius sunaudoja beveik dvigubai mažiau energijos, o paslaugu sektorius net 2,5 karto mažiau. Tačiau pagal tai, kam vartojama energija (patalpų šildymui ir apšvietimui), namų ūkių ir paslaugų sektoriai iš esmès yra labai panašūs, ir kartu šiuose sektoriuose sunaudojama beveik pusé (46\%) visos suvartojamos energijos. Lietuvos Respublikos užsienio reikalų ministerijos ataskaitoje dèl šiltnamio efektą sukeliančių dujų mažinimo (COWI 2011) didieji energijos vartotojai ivvardinti dar paprasčiau: ,pastatai ir transportas". Vadovaujantis apsibrěžtomis darbo riboms, toliau bus aptariama pastatuose suvartojama energija, sujungiant namų ūkio ir paslaugų sektorius i vieną bloką ir gyvenamaji pastatą ịvardijant kaip charakteringą vienetą.

$2011 \mathrm{~m}$. Statistikos departamentas publikavo medžiagą apie kuro ir energijos suvartojimą namų ūkiuose, apibendrinti tyrimo duomenys buvo pateikti leidinyje „Energijos sunaudojimas namų ūkiuose 2009“ (LSD 2011b). Leidinị sudaro dvi dalys, iš kurių pirmoji skirta namų ūkiams ir būstams charakterizuoti (pvz., vienam namų ūkiui tenkantis šildymo plotas, asmenų skaičius ir pan.), o antrojoje surinkta statistine informacija apie energijos suvartojimą ir išlaidas energijai. Kaip nurodyta leidinyje, surinkta ir apdorota statistiné informacija reikalinga nustatant, kokią dali šalies kuro ir energijos balanse sudaro namų ūkiuose suvartojama galutinè energija, be to, rinkti duomenis apie namų ūkiu energetinius poreikius ịpareigoja Europos Parlamento ir Tarybos reglamentas Nr. 1099/2008 dèl energetikos statistikos.

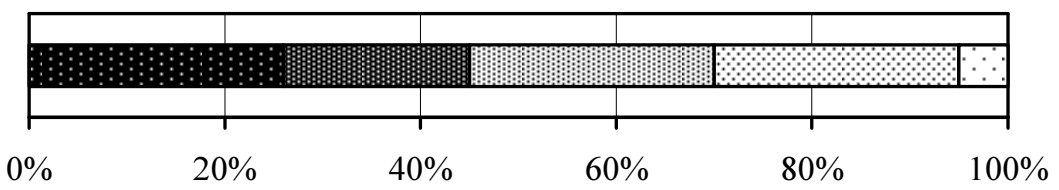

Biki 1960 m. 围 1961 - 1970 圈 1971 - 1980 용 1981 - $1990 \square 1991-1996$

3.7 pav. Daugiabučiai gyvenamieji namai pagal statybos metus

Fig. 3.7. Multi-dwelling buildings by year of construction 
Tyrimo (LSD 2011b) metu nustatyta, kad beveik $70 \%$ būstu yra miestuose, $85 \%$ visų būstų miestuose yra pastatyti nuo 1947 m. iki $1991 \mathrm{~m}$. Didžiają dali (81\%) gyvenamojo fondo miestuose sudaro butai daugiabučiuose, ir daugiausiai - $69 \%$ - daugiabučių pastatų buvo pastatyta per 30 metu laikotarpi, trukusį nuo $1961 \mathrm{~m}$. iki $1991 \mathrm{~m}$. (3.7 pav.). Iš viso iki $1993 \mathrm{~m}$. buvo pastatyti 34246 daugiabučiai gyvenamieji pastatai (Rogoža et al. 2008). Beveik visa sunaudojama energija (81 \%) skiriama patalpų šildymui ir karštam vandeniui, tiek kalbant apie vienbučius, dvibučius gyvenamuosius namus, tiek ir apie daugiabučius (3.8 pav.). Skiriasi tik šilumos generavimo būdai: vienbučiams ir dvibučiams namams šildyti daugiausia naudojamos malkos (apie $70 \%$ ), o būstams miestuose šiluma tiekiama centralizuotais tinklais (apie $75 \%$ ). Lyginant su kitais ES miestais, būstai Lietuvos miestuose yra maži, net $42 \%$ sudaro būstai, kurių apšildomas plotas tèra $20-49 \mathrm{~m}^{2}$.

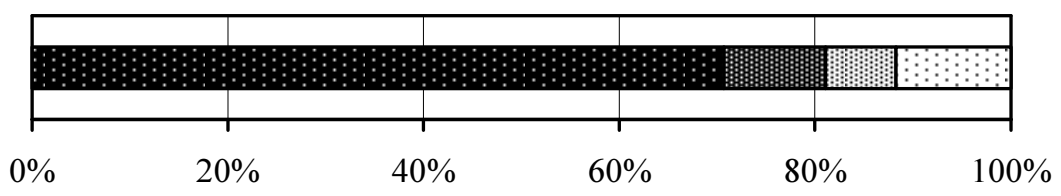

D Patalpų šildymas 圈 Karštas vanduo 国 Maisto gaminimas $\boxminus$ Kita

3.8 pav. Energijos suvartojimas namų ūkiuose

Fig. 3.8. Household energy consumption

Darbui statistiniai duomenys svarbūs dèl juose randamo atsakymo i aukščiau iškeltus klausimus: kas sunaudoja daugiausiai energijos ir kokios pagrindinès šio poreikio priežastys? Statistiniuose duomenyse aiškiai išsiskiria vienas istorinis periodas, kai Lietuva buvo okupuota Sovietų Sajungos. Sajunga subyrèjo, tiksliau, žlugo politinè santvarka, tačiau fizinis palikimas (greta kitų šiuo metu vis dar evoliucionuojančių ideologinių pasekmių: mentaliteto, istorijos suvokimo ir pan.) liko. Liko ne pavieniai pastatai, bet ištisi miestai ar didelès jų dalys, suprojektuoti ir pastatyti (tai ypač svarbu) pagal tų laikų standartus bei galimybes: monofunkciniai rajonai, dideli sugrupuoti pramoniniai kompleksai, vienas po kito nutisstantys gyvenamieji (miegamieji) rajonai. Pastarujų metų tyrimuose (Verbeeck and Hens 2010; Blom et al. 2011; Wallhagen et al. 2011; Cuéllar-Franca and Azapagic 2012) teigiama, kad apskritai daugiausia energijos pastatuose sunaudojama eksploataciniu laikotarpiu, todèl fizinio palikimo, statyto pagal 1970-ujjų metu galimybes, išlaikymas dabartinèmis sąlygomis yra ypač problemiškas, plačiai aptarinejjamas specialistų, politikų ir empiriškai patiriamas kiekvieno buto savininko. 
3.1 poskyryje rašyta, kad Lietuvoje centriniam šildymui (pagrindinis būstų šildymo būdas miestuose) reikalinga energija beveik išimtinai gaunama iš naftos, todèl energijos suvartojimas tiesiogiai susijęs su šiltnamio dujų emisija. Sumažinus pastatų energijos poreikius šildymui, atitinkamai sumažètų emisija, taigi ir miestu ,indèlis““ i klimato kaitą. Šią loginę seką vertinant darbo kontekste, daroma išvada, kad pagrindinis taikinys yra statistinis tarybinio laikotarpio daugiabutis namas, savo energetiniais poreikiais (ir su tuo susijusia ekologine žala) labiausiai reprezentuojantis dominuojančią statybą Lietuvos miestuose.

Pastaruoju metu Lietuvoje vyrauja nuostata, kad situaciją labai pagerintų pastatų modernizavimas, modernizavimo programa remiama ir skatinama net aukščiausiu politiniu lygmeniu. Modernizavimas, be abejo, orientuotas i išlaidų šildymui mažinimą, kas tiesiogiai susiję su šilumos nuostoliais ir tuo pačiu energijos suvartojimo efektyvumo didinimu. Pasiekti tikslą, kaip dažniausiai teigiama, galima apšiltinus visą pastatą (tiksliau, cokolio, sienų ir stogo apšiltinimas bei langų ir durų keitimas i šiuolaikinius). Ginčyti faktą, kad visiškai apšiltinus pastatą šilumos nuostoliai bus mažiausi, nèra prasmès, jis akivaizdus, tačiau darbo kontekste tikslingesnis yra šiek tiek kitaip suformuotas tikslas.

Sprendžiant miesto išorinès ekologijos problemą, svarbu nustatyti, kokios priemonès yra reikalingos rengiant miestų bendruosius planus, kad dèl energijos suvartojimo susidaranti emisija atitiktu 2.3 poskyryje nurodytus tikslus (2.5 pav.). Darbe keliama hipotezè, kad minètiems tikslams pasiekti pakaktų atlikti dalini pastatų modernizavimą, t. y. taikyti tik tam tikras atnaujinimo priemones. Manoma, kad plataus masto veikimas (koks ir būna bendrojo plano atveju) leidžia naudoti paprastesnes (techniškai lengviau igyvendinamas, priimtinas gyventojams ir pan.) priemones, be to, atsiranda galimybé ne tik kosmetiškai pakeisti pastato išorę, bet ir koreguoti jų aplinką. Tokios prielaidos atsiradimą labiausiai sąlygotų du veiksniai: darbu siekiama realiai pritaikomų sprendimų, o dabartinè pastatų modernizavimo programa nesulaukia tinkamo visuomenès palaikymo (Alfa 2013a) ir modernizavimo tempas nèra pakankamai spartus. Prieš 5 metus modernizavimo programoje dalyvavo tik $2,1 \%$ visų galinčių dalyvauti programoje daugiabučių (Rogoža et al. 2008), situacija liko panaši ir vèliau - $2010 \mathrm{~m}$. buvo ịvykdyti tik 76 modernizavimo projektai, iskaičiuojant 2 aukštu 4 butų daugiabučius (Miesto renovacija 2011). Masine pastatų modernizavimo galimybę (apie 1000 pastatų per metus) vis dar atsargiai vertina ir komercinių bankų ekonomistai (Alfa 2013b).

Darbe laikomasi pozicijos, kad renkantis, kokius darbus būtų tikslinga atlikti siūlomos dalinès renovacijos atveju, būtina atsižvelgti ị pastatų savininkų (naudotojų) interesus ir nuomonę net tada, jei jie moksliškai, ekonomiškai ar politiškai neatrodytų pačia tinkamiausia priemone. Esama situacija atskleidžia, 
jog sprendimai, priimti politiniu lygmeniu, netampa realiai igyvendinamais, o skyrus prioritetą socioekonominei realybei, galima tikètis, kad siūlomi darbai bus priimti noriai ir realizuoti. Žmonių nuomonès ir (kas, ko gero, dar svarbiau) intuityvios, subjektyvios preferencijos aiškiai atsiskleidžia modernizavimo monitoringo rezultatuose (Rogoža and Martinaitis 2007; Rogoža et al. 2008; Miestų renovacija 2011). Pačia populiariausia būsto atnaujinimo priemone jau kuris laikas yra langų ir / arba balkono durų keitimas, ataskaitose užfiksuota, kad dalis langu ir durų jau buvo pakeisti iki prasidedant renovacijos darbams, t. y. gyventojai sprendimą keistis langus / duris prièmé savarankiškai ir negaudami valstybès paramos. Langai ir durys keičiami net bendrabučio tipo namuose, kurių statybos kokybè, estetine ir rinkos vertès ypač žemos. Pasirinkimo patrauklumas (Rogoža et al. 2008) grindžiamas sąlyginai maža (prieinama) produkto kaina, iš karto jaučiamu efektu (triukšmo, skersvejjų sumažèjimas) ir faktu, kad gyventojai jaučiasi betarpiškais investicijos savininkais. Ivertinant minètą informaciją, daroma prielaida, kad 2.3 poskyryje nustatytus tikslus būtų galima pasiekti taikant tik vieną - langu / durų keitimo - priemonę, tačiau ji turètų būti taikoma masiniu (viso miesto) mastu. Be abejo, analogišką rezultatą leistu pasiekti ir visiųkas pastato modernizavimo paketas, tokiu atveju pakaktų mažiau namų, tačiau $2010 \mathrm{~m}$. rezultatai (panašiai kaip ir ankstesnių metų) yra nepakankami: 76 projektų visos valstybès mastu negana.

Remiantis aukščiau minètais statistiniais duomenimis ir monitoringo rezultatais, skaičiavimams pasirinktas charakteringas statistinis tarybinio laikotarpio daugiabutis namas. Pastatas turètų būti stambiaplokštis, pastatytas apie 1970 metus, penkių aukštų, šešiasdešimties butų, šildomas plotas apie $2710 \mathrm{~m}^{2}$. Ataskaitose statistinio pastato techniniai rodikliai nežymiai skiriasi (pvz., šildomas plotas $2791 \mathrm{~m}^{2}$ (Rogoža et al. 2008)), tačiau jie neturi esminès itakos nagrinejjamam aspektui. Kartu su bendraautoriais M. Medineckiene, E. K. Zavadsku ir D. Kalibatu buvo publikuotas straipsnis (Staniūnas et al. 2013), kuriame detaliau išskleidžiami skaičiavimai, todèl disertacijoje pateikiami tik svarbesni momentai.

Prieš pradedant skaičiavimus buvo padaryta prielaida, jog pastate visi langai ir balkono durys yra seni ir visi bus keičiami. Esami langai ir durys mediniais sudvejintais rèmais su dvigubu paprastu ịstiklinimu, tokių langų skaičiuojamasis šilumos perdavimo koeficientas $-2,5 \mathrm{~W} / \mathrm{m}^{2} \mathrm{~K}$. Pagal suvartojamą šilumos kiekị statistinis daugiabutis priskiriamas III kategorijai: vidutinis šilumos suvartojimas šildymui siekia apie $25 \mathrm{kWh} / \mathrm{m}^{2}$ per ménesi - tai yra vidutinis šilumos suvartojimas per penkis pilnus ménesius, atskirais ménesiais šilumos suvartojama skirtingai (LSTA 2012). Vadinasi, bendras viso namo šildymo poreikis per ménesi yra $67750 \mathrm{kWh}$, o per šildymo sezoną (penki pilni statistiniai ménesiai pagal LSTA) - $338750 \mathrm{kWh}$. Skaičiuojant emisiją, susidarančią dèl minèto šilumos kiekio, buvo remtasi Lietuvos šilumos tiekejju 
asociacijos (LSTA) apibendrintais duomenimis. LSTA (2012) teigia, kad centralizuotai tiekiamos šilumos (būtent taip šildoma didžioji dalis būstų miestuose (LSD 2011b)) $1 \mathrm{kWh}$ gamybai Lietuvoje reikia sudeginti apie $100 \mathrm{~g}$ kuro, skaičiuojant naftos ekvivalentu, didžiausią dali $2011 \mathrm{~m}$. sudare iškastinis kuras (iš esmès gamtinès dujos), likusią dalị (22\%) sudare atsinaujinantys energijos ištekliai (mediena, šiaudai ir pan.). Europos aplinkos agentūros (EEA 2011) duomenimis, jei šilumos gamybai naudojamos gamtinès dujos, tai $1 \mathrm{kWh}$ šilumos atitinka $0,251 \mathrm{~kg} \quad \mathrm{CO}_{2}$ ekvivalento emisiją. Remiantis minètais duomenimis, sudaryta (3.5) formulè, leidžianti apskaičiuoti apytikslę pastato ekologinę žalą pagal suvartojamos centralizuotai tiekiamos šilumos poreikị:

$$
E_{1}=5 S \lambda \alpha,
$$

čia $E_{l}$ - emisija, išreikšta $\mathrm{kg} \mathrm{CO}_{2}$ ekvivalento per skaičiuojamuosius metus (šildymo sezoną), $S$ - pastato šildomas plotas $\mathrm{m}^{2}, \lambda-$ vidutinis šilumos suvartojimas šildymui per mėnesi (darbe $25 \mathrm{kWh} / \mathrm{m}^{2}$ ) ir $\alpha$ - šilumos $1 \mathrm{kWh}$ atitikmuo $\mathrm{kg} \mathrm{CO}_{2}$ ekvivalentu.

Pagal (3.5) formulę apskaičiuota, jog pagaminus $338750 \mathrm{kWh}$ centralizuotai tiekiamos šilumos, kuri reikalinga statistinio 60 butu daugiabučio šildymui vieno šildymo sezono metu, į atmosferą išskiriama apie $85026 \mathrm{~kg} \mathrm{CO}_{2}$ ekvivalento.

3.1 lentelè. Pokyčiai, susiję su langų ir durų pakeitimu

Table 3.1. Changes due to windows and doors replacement

\begin{tabular}{|l|l|l|l|l|l|}
\hline $\begin{array}{l}\text { Vari- } \\
\text { antas }\end{array}$ & $\begin{array}{l}\text { Istik- } \\
\text { lintas } \\
\text { plotas, } \\
\mathrm{m}^{2}\end{array}$ & $\begin{array}{l}\text { Šilumos } \\
\text { perdavimo } \\
\text { koeficientas, } \\
\mathrm{W} / \mathrm{m}^{2} \mathrm{~K}\end{array}$ & $\begin{array}{l}\text { Metinès } \\
\text { energijos } \\
\text { sąnaudos, } \\
\mathrm{kW} / \mathrm{m}^{2}\end{array}$ & $\begin{array}{l}\text { Metine emisija, } \\
\text { susidaranti dèl } \\
\text { silumos } \\
\text { nuostoliu, } \\
\text { kg CO} \\
\text { ekvivalento }\end{array}$ & $\begin{array}{l}\text { Emisijos } \\
\text { sumažejimas } \\
\text { lyginant su } \\
\text { esama } \\
\text { padètimi, } \\
\%\end{array}$ \\
\hline Esamas & 598 & 2,50 & 56,56 & 38473 & - \\
\hline 1 & 598 & 1,00 & 22,63 & 15393 & 60 \\
\hline 2 & 598 & 0,70 & 15,84 & 10774 & 72 \\
\hline 3 & 598 & 0,60 & 13,58 & 9237 & 76 \\
\hline 4 & 598 & 0,50 & 11,31 & 7693 & 80 \\
\hline
\end{tabular}

Skaičiuojamosios energijos sąnaudos per esamus langus ir balkono duris sudare $153278 \mathrm{kWh}$ per šildymo sezoną. Generuojant šiluminę energiją, reikalingą apskaičiuotiems šilumos nuostoliams padengti, i atmosferą išmetama $38473 \mathrm{~kg} \mathrm{CO} 2$ ekvivalento per šildymo sezoną ir tai sudaro $45 \%$ visos namo 
metinès šildymo emisijos. Akivaizdu, kad visiškai išvengti šilumos nuostolių per langus nèra įmanoma, tačiau nuo pasirinktų naujų langų techninių charakteristikų nuostoliai (tuo pačiu ir emisijos sutaupymai) yra nevienodi. Langų ir balkono duru keitimas numatytas i plastikinius (PVC) paketinius - tai populiariausias sprendimas Lietuvoje, kuris, atsižvelgiant i socioekonominę situaciją, neturètų keistis ir ateityje. Viena iš pagrindinių priežasčių - ypač prieinama kaina. Skaičiavimams atrinkti šiuo metu dažniausiai užsakomus modelius atitinkantys variantai: $70 \mathrm{~mm}$ storio PVC rèmas su vienu $24 \mathrm{~mm}$ stiklo paketu ir vienu selektyviniu stiklu, $78 \mathrm{~mm}$ storio PVC rèmas su $36 \mathrm{~mm}$ dvieju kameru stiklo paketu ir vienu selektyviniu stiklu, $82 \mathrm{~mm}$ storio PVC rémas su 44 $\mathrm{mm}$ dviejų kameru stiklo paketu ir dviem selektyviniais stiklais ir $92 \mathrm{~mm}$ storio PVC remas su $52 \mathrm{~mm}$ dviejų kamerų stiklo paketas su trimis selektyviniais stiklais. Visuose variantuose stiklo paketai užpildyti argono dujomis. Apibendrinti skaičiavimų rezultatai pateikti 3.1 lentelèje.

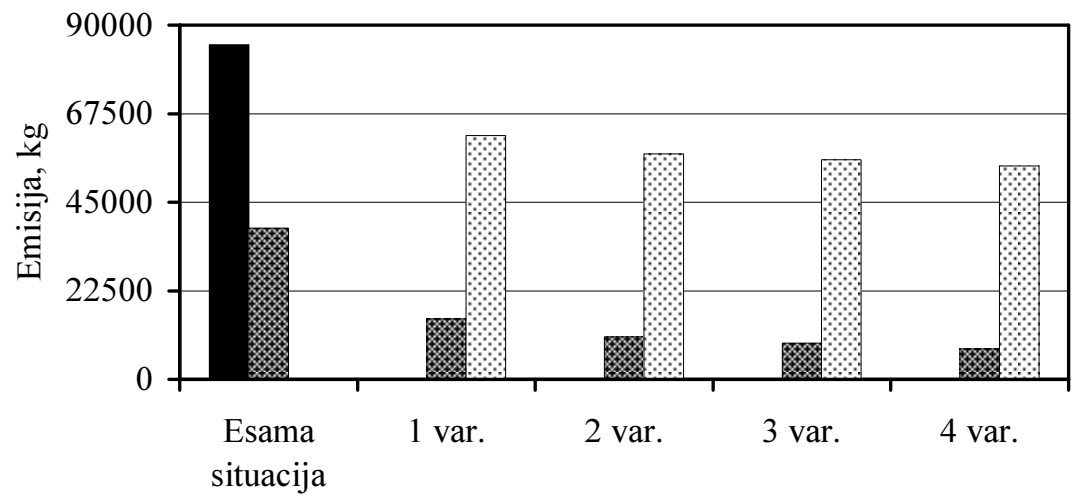

Esama bendra emisija Emisija dèl langų

Bendra emisija po langų pakeitimo

3.9 pav. Emisija $\mathrm{kg} \mathrm{CO}_{2}$ ekvivalentu dèl langu

Fig. 3.9. Emission ( $\mathrm{kg} \mathrm{CO}_{2}$ equivalent) due to windows

Iš 3.1 lentelès matyti, kad esamų langų keitimas net ị pačius paprasčiausius šiuolaikinius būtų ypač efektyvus sprendimas, leidžiantis sumažinti emisiją daugiau kaip du kartus. Kadangi darbui yra svarbūs ne tiek santykiniai sutaupymai (langu tarpusavio palyginimas), kiek pokytis bendrame balanse, buvo palyginti galimi sutaupymai su visa namo emisija: pirmuoju atveju bendra emisija būtų sumažinta $27 \%$, antruoju - $33 \%$, trečiuoju - $34 \%$ ir ketvirtuoju $36 \%$ (3.9 pav.). Lyginant su esama padètimi, bet kuris (pilnas) langu keitimo 
variantas labai prisidètu prie bendros emisijos mažinimo ir tenkintų 2.3 poskyryje nustatytus emisijų mažinimo tikslus. Visi variantai, išskyrus pirmajji, atitiktų ir net viršytų griežčiausią (30 \% mažinimo) tikslą.

Pasiteisinus prielaidai dèl langų keitimo priemonès efektyvumo, šią priemonę naudinga įtraukti ị miesto bendrujų planų rengimą, tačiau, suplanavus masinį langu keitimą, priemonès igyvendinimą (net ir žinant gyventojų prielankumą) reikètų vertinti atsargiai. Pakeisti didesnio miesto daugiabučių namų langus gali užtrukti ilgiau, nei galios bendrojo plano sprendiniai, be to, pakeitus langus naujais, emisija dèl langų bendrame balanse labai sumažèja (3.9 pav.). Pavyzdžiui, remiantis 4 varianto skaičiavimais, emisija dèl naujų langų sudarytų tik $14 \%$, todèl stengiantis emisijas mažinti ir vẻliau, reikètų ieškoti papildomų galimybių - svarstyti efektyvesnes perplanavimo galimybes.

Smarkiai supaprastinus, miestų bendrujų planų rengimo metu įmanomos tik dvi miesto vystymo galimybès: leisti naujų pastatų statybą arba skatinti jau esamų pastatų pertvarkymą. Pirmają alternatyvą pagal tai, kur būtų vykdomos statybos, galima papildomai išskirti i du pogrupius: statyba naujuose plotuose, plečiant miesto ribas, arba statyba pertvarkant miesto vidines teritorijas, nedidinant miesto ribų. Praktikoje nei vienas iš variantų nèra sutinkamas grynuoju pavidalu ir dažniausiai taikomos mišrios priemonès, tačiau Lietuvoje dažniausiai esamų gyvenamųjų pastatų pertvarkymas miestuose išimtinai siejamas su jų išsaugojimu (pvz., dabartinè daugiabučiu modernizavimo programa). Vertinant tiek Lietuvos lygmeniu, tiek pasauliniame kontekste, masinis stambiaplokščiu pastatų saugojimas - keista praktika dèl daugybès dideliu trūkumų, susijusių su pastatų techninèmis savybèmis, estetine kokybe, socialine programa ir su tuometinio planavimo principais / poreikiais.

Lietuvoje tiek pačių miestų, tiek ir gyvenamojo fondo juose intensyvejjimas neatsiejamas nuo istorinių faktų, tiksliau Sovietų Sajungos okupacijos po II pasaulinio karo. XX a. viduryje Lietuva vis dar buvo agrarinè valstybè su dominuojančia kaimo populiacija, šali miestiečių skaičiumi lenke kitos Pabaltijo valstybès: Latvija ir Estija. Lietuvoje miesto gyventoju skaičius susilygino su kaimo gyventojų skaičiumi tik prieš kiek daugiau nei 40 metų $(3.10$ pav.) (Vaitiekūnas 2006). Po okupacijos Lietuvoje, kaip ir kitose Sovietų Sajungos valstybėse, siekiant įveikti ekonominị rytų bloko atsilikimą, buvo pradèta sparti krašto industrializacija, kuriai igyvendinti buvo reikalinga didelè žmonių santalka - miestas. Lietuvoje, remiantis Čekoslovakijos urbanistų patirtimi, pradèta taikyti krašto tolygaus vystymo idejja, paremta ,sajungine pramonès plètros direktyva“, todèl buvo numatyta dešimt naujų plètotinų pramonės miestų: Alytus, Marijampolè, Utena, Plungè, Jurbarkas, Jonava, Kèdainiai, Mažeikiai, Švenčionèliai ir Rokiškis (Miškinis 1990). Atskirai kategorijai reikia priskirti miestus, kurie buvo visiškai naujai sukurti - pastatyti iki tol tuščiose, negyventose teritorijose - ir skirti vienai pramonès šakai, Lietuvoje jų buvo šeši: 
Baltoji Vokè, Tyruliai, Grigiškès, Naujoji Akmenè, Elektrènai ir Visaginas (tuomet Sniečkus) (Drèmaitè, Petrulis, Tutlytė 2012). Miestu statybos turèjo vykti sparčiai, tai buvo politiškai itvirtintas procesas. Lietuvos miestai buvo nuosekliai kuriami / užstatomi socialistinès santvarkos produktais: ideologiškai teisingais apskaičiuotos architektūros pigiais pagaminti daugiabučiais gyvenamaisiais namais. Tai, kas Vakaruose buvo laikoma laikinu sprendimu ir iš principo skirta socialiniams būstams, Lietuvoje tapo namais didžiajai daliai naujujų miestiečių (3.7 ir 3.10 pav.). Vakaruose surenkamujų daugiabučių namų bumas pradejo rimti gana greitai - issimintiniausia data laikomi 1972 metai, kai Naujajame Orleane buvo susprogdintas daugiabutis, o Sovietų Sajungoje tai buvo beveik išimtinai vienintelis miestų užstatymo būdas, nusitęsęs dar 19 metų po sprogimo.

Intensyvi daugiabučių statyba

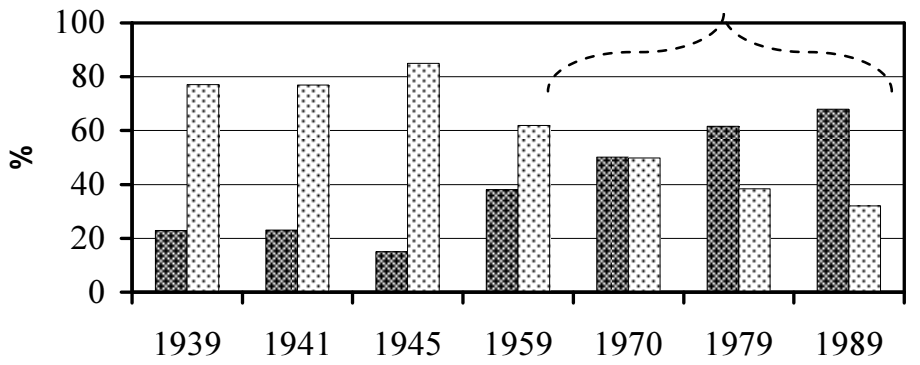

Miestiečiai Kaimo gyventojai

3.10 pav. Gyventojai Lietuvoje $1939-1989 \mathrm{~m}$.

Fig. 3.10. Population in Lithuania, 1939-1989

Atsižvelgiant i daugiabučiu atsiradimo prielaidas Lietuvos (ir kituose buvusios Sovietų Sajungos) miestuose, modernizavimo programa, orientuota $i$ šiuos pastatus, kelia abejonių. Programoje vyraujantis inžinerinis požiūris naujas apšiltinimo sluoksnis ir nauji PVC langai - užtikrins šiuolaikiškus techninius rodiklius, tačiau iš esmès nepašalins Ernst May išpopuliarintos ir vèliau sovietų masiškai tiražuotos ,existenzminimum“ programos. Remiantis Švedijos renovavimo patirtimi, „krūmai ir fasadų spalvinimas nepadidino laimès“ (Drèmaitė 2006). Lietuvoje daugiabučiu namų klausimas nèra vienareikšmiškai priimamas: gyventojų nenoras modernizuoti pastatų jau buvo minètas, tačiau abejonių kyla ir ekspertams, kritika pasiekia ir žiniasklaidos priemones (Delfi 2013b).

Gali pasirodyti, kad sovietinių miegamujų rajonų nugriovimas ir pilnas perplanavimas būtų tinkamiausia priemonè, tačiau Lietuvoje tai tebūtų teorinis pasvarstymas. Praktikoje, atsižvelgiant ị socioekonominę padètį ir faktą, kad po 
nepriklausomybès atkūrimo buvo leista (faktiškai netgi skatinama) masiškai išsipirkti butus, pastatu griovimas būtų suvoktas kaip pasikèsinimas į privačią nuosavybę, todèl, grižtant prie energetinio ir ekologinio aspektų, darbe keliama prielaida, kad būtų tikslinga dar kartą taikyti dalinị pastatų modernizavimą, tik šiuo atveju kitu masteliu. Dalinis modernizavimas turètų apimti ne tam tikrus smulkius pastato elementus, bet pati pastatą, jų grupes ir supančią aplinką, tai leistų ne tik kosmetiškai pakeisti esamų pastatų išorę, bet ir pakoreguoti jų užstatymo struktūrą - tą esminị elementą, kurio negalima pakeisti taikant ị techninius parametrus orientuotą prièjimą. Užsienyje, pavyzdžiui, Vokietijoje (Halberstadt, Schwedt, Berlyne), Olandijoje (Bijlmermeer) yra taikoma panaši praktika, Vokietijos rytineje dalyje darbai vykdomi ypač dideliais masteliais (Berlin-Marzahn nugriauta $75 \%$ gyvenamojo ploto), dažnai taikomas ir visiškas funkcionalistinių gyvenamujų pastatų nugriovimas (Flecken 2005; Bijlmermeer Renovation Planning Office 2008).

Sovietiniai miestai pasižymèjo retu užstatymu (Zagorskas 2007; Alchimoviené 2012), gyvenamieji rajonai užèmé didelius plotus, tarp kurių buvo papildomai palikti neužstatyti tarpai, pavyzdžiui, Karoliniškių, Justiniškių rajonai Vilniuje. Taikant dalinị perplanavimą, būtų galima numatyti naujų pastatų statybą ją ịterpiant tarp jau esamų daugiabučių, tačiau - ir tai svarbu - ne labiau didinant rajono intensyvumo rodiklį (tai gyventojai suvokia kaip neigiamą aspektą), o pasiūlant esamiems gyventojams butą naujame name mainais $\mathfrak{i}$ leidimą nugriauti jų buvusị butą. Toks modelis Lietuvos atveju yra realus, ypač ịvertinus neigiamą demografinę statistiką ir tolesnes prognozes. Politiniu lygmeniu miestų susitraukimas dèl depopuliacijos nèra pripažįstamas, tačiau reiškinys realiai vyksta daugumoje miestų (pvz., Kaune, Panevėžyje). Naujieji pastatai būtų statomi faktiškai toje pačioje vietoje, kurią gyventojai (mikrorajono lygmeniu) identifikuotuc kaip „savo“, todèl vietos tapatybès, prisirišimo problema būtų sumažinta iki minimumo. Naujos statybos pastatai ne tik atitiktų šiuolaikines technines normas, tačiau leistų priartinti rajono struktūrą prie šiuolaikinès daugiafunkcinès: pastatuose galètų būti numatyti plotai komercinei veiklai. Veikiant kompleksiškai (bendrojo plano masteliu) ir atitinkamai sutarus su gyventojais, būtų įmanomas pilnas arba dalinis esamų daugiabučių aukštų nurinkimas, t. y. būtų sumažintas rajono aukštingumas ir pastato mastelis. Siūlomas sprendimas leistų sukurti smulkesnę ir tankesnę struktūrą, kuri drauge atvertų naują emisijų mažinimo galimybę.

Darbo rezultatams nèra svarbi konkreti tyrimo vieta, miestas, rajonas, nes daugiabučiu gyvenamujjų namų projektavimo ir statybos standartai buvo bendri visai Sovietų Sajungai ir vietine specifika niekuomet nebuvo lemiamas veiksnys. Tyrimui svarbesni aspektai yra užstatymo morfotipas ir aukštingumas, nes būtent jie techniškai apriboja naujų pastatų ịterpimo sąlygas. Laisvas planavimas buvo dominuojanti to laikotarpio planavimo kryptis, o gyvenamujų namu 
statyboje vyravo 5, 9 ir 12 aukštų pastatai. Darbe, kaip jau buvo minèta, atsižvelgus i Statistiko departamento informaciją, pasirinktas tipinis objektas statistinis tarybinio laikotarpio penkiaaukštis daugiabutis namas, toliau pateikiami konkretūs pavyzdžiai tik dèl aiškumo ir iliustratyvumo. Analizuotos teritorijos trijuose Lietuvos miestuose: Vilniuje, Kaune ir Klaipedoje. Laikantis aptartos dalinès perplanavimo idejos, bandyta nustatyti, ar įmanoma iterpti naujos statybos gyvenamujų pastatų $i$ esamus miegamuosius rajonus ir kiek tokiu atveju sumažètų emisija, susijusi su šiluminès energijos suvartojimu pastatuose.

Tyrimo metu naudotos maps.google.com, bing.com/maps ir maps.lt interneto žemèlapių svetainès, kuriomis remiantis buvo parengtos apibendrintos analizuotų miestų rajonų schemos (3.11 pav.). Nustatyta, kad atstumas tarp penkiaaukščių gyvenamųjų pastatų svyruoja nuo maždaug 30 iki 70 metrų, tačiau, pavyzdžiui, Klaipedoje namai sustatyti grupèmis, tarp kurių palikti dar didesni atstumai. Mažesnis atstumas užfiksuotas tada, kai tarp pastatų yra privažiavimas / akligatvis su nedidele automobilių stovejjimo aikštele, o atstumas didesnis, jei yra numatyta papildoma infrastruktūra, pavyzdžiui, pėsčiųjų takas ar žaliasis plotas. Atstumai tarp pastatų patikslinti atlikus kontrolinius matavimus vietoje Vilniuje. Esminių nukrypimų nebuvo užfiksuota, todèl interneto žemèlapių svetainių duomenys darbe laikomi patikimais. Pastatų aukštis dèl buvusių vienodų sajunginių statybos standartų visur priimtas vienodas - 15 metrų, natūroje skiriasi tik cokolinès pastatų dalys, kurios neturi esminès įtakos darbo rezultatams.

Perplanuojant užstatymą, siūloma 60 butu penkiaaukščio namo vieną aukštą nurinkti visiškai, o kito pusę, t. y. demontuoti 18 butų. Ketvirtą aukšto nuardant ne ištisai, o su tarpais, atsirastų galimybe šio aukšto gyventojams pasiūlyti terasas, kurios atsirastų tarp blokų / butų. Daugiabučio šildomas plotas apie $2710 \mathrm{~m}^{2}$, todèl statistinis butas kartu su pagalbiniu šildomu plotu (laiptine) užima apie $45 \mathrm{~m}^{2}$, o 18 butu $-810 \mathrm{~m}^{2}$. Jau buvo minèta, kad Statistikos departamento duomenimis Lietuvos būstai ES kontekste maži, todèl, perplanuojant rajoną, būtų logiška ne tik pasiūlyti pastatus su geresniais techniniais parametrais, bet ir padidinti gyventojų komforto lygi, numatyti plotą komercinei veiklai, bendro naudojimo patalpoms. Kitaip sakant, būtų tikslinga orientuotis ne ị tokị patị plotą, kuris būtų nuardomas, bet ị didesnị. Čia verta prisiminti, kad jau prieš daugiau kaip 20 metų atliktų urbanistinių sociologinių tyrimų metu (Vanagas 1992), gyventojai nurodè, kad butuose trūksta erdvès: didesnès virtuvès, kamaraitès (sandèliuko), bendro naudojimo patalpų. Darbe siūloma naujų butų plotą padidinti penktadaliu iki $55 \mathrm{~m}^{2}$ (kartu su laiptine) ir naujame name suprojektuoti $10 \%$ daugiau butu, t. y. iš viso 20 butu, iš kurių 18 būtų skirta kompensavimui ir 2 naujakuriams. 

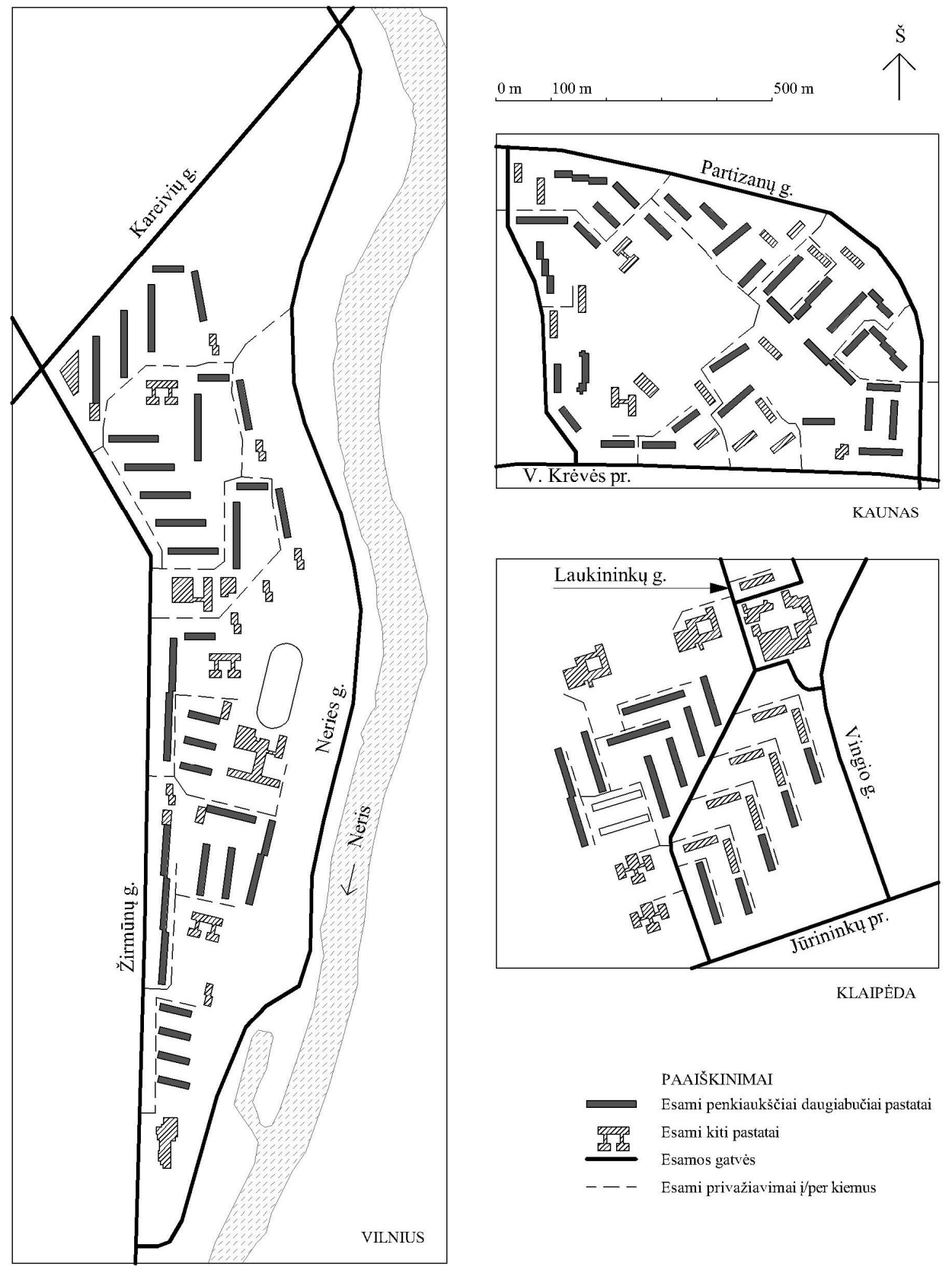

3.11 pav. Miestų rajonų schemos

Fig. 3.11. Schemes of urban districts 
Analizès metu užfiksuota, kad atstumas tarp pastatų varijuoja ir tarp pastatų grupių yra didelių tuščių plotų, tačiau darbe laikomasi pozicijos išlaikyti užstatymo charakterị, t. y. manoma, kad nauji pastatai turètų būti statomi (iterpiami) tarp esamų. Sprendimas sunkiau igyvendinamas architektūriniu požiūriu, tačiau tokiu būdu išlaikoma jau suformuota (ir žmonių priimta) rajono kompozicija. Tarp pastatų vyraujantis tipinis atstumas - 34-40 m, todèl naujasis namas turètų būti panašaus pločio kaip esami daugiabučiai, t. y. 12-13 m. Tarp pastatų likęs tarpas 11-14 m būtų artimas pertvarkomų daugiabučių aukščiui (4 aukštai, iš viso apie 12-13 m), todèl būtų užtikrinti higieniniai insoliacijos reikalavimai (STR 2.02.01:2004) ir išlaikomas reglamentuotas priešgaisrinis atstumas (Gaisrinès saugos pagrindiniai reikalavimai) (3.12 ir 3.13 pav.). Planuojant statyti sąlyginai siaurus namus, tikslinga pastato funkcinę programą išdèstyti per tris aukštus: pirmame aukšte būtų suplanuoti komercinès ir inžinerinès (dviračiu ir automobilių saugyklos) paskirties plotai, o antras ir trečias aukštai būtų skirti butams. Kiekvieno aukšto plotas - apie $550 \mathrm{~m}^{2}$, iš viso - apie $1650 \mathrm{~m}^{2}$. Papildomas tokio sprendimo privalumas - rajono aukštingumo nepadidinimas, nes dažniausiai, statant naujus pastatus, pridedami 1-3 aukštai, ir toks sprendimas rajono senbuviams, susigyvenusiems su užstatymo charakteriu, nebūna priimtinas.

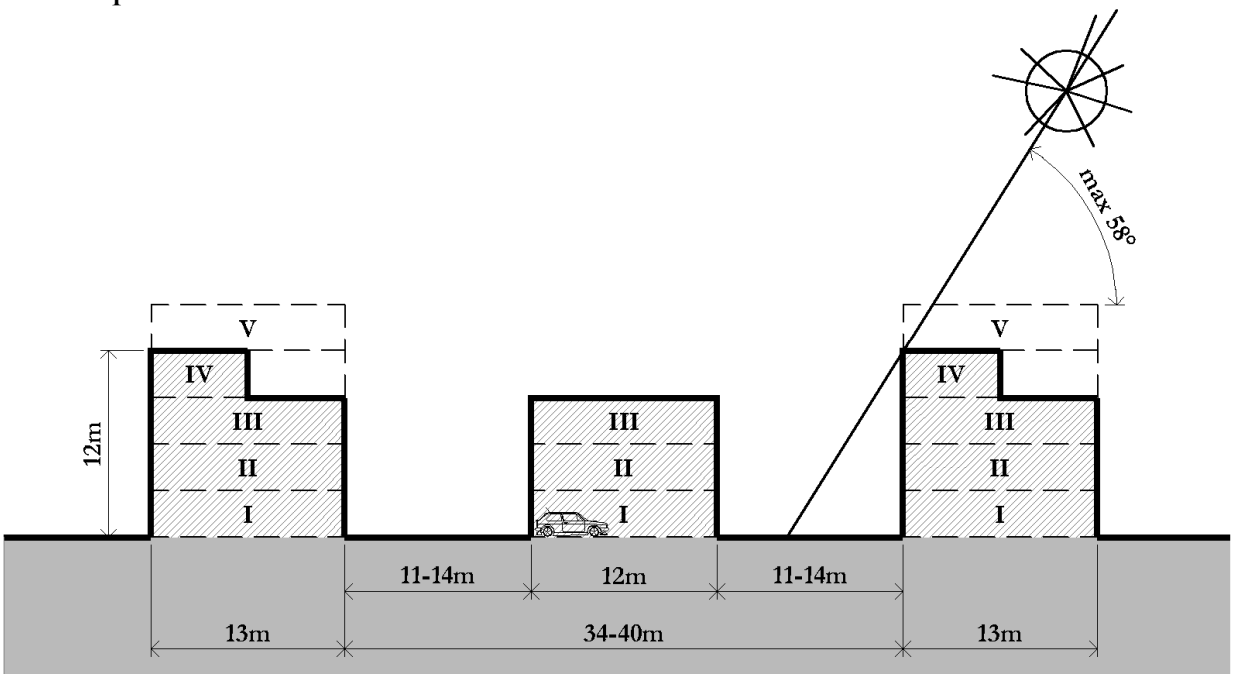

3.12 pav. Principinis pjūvis po dalinio perplanavimo

Fig. 3.12. Principal section after partial replanning

Remiantis STR 2.06.01:1999 „Miestų miestelių ir kaimų susisiekimo sistemos“, naujiems butams būtų reikalinga 20 automobilių stovejjimo vietų, todèl, automobilius statant statmenai važiavimo ašiai, reikès $400 \mathrm{~m}^{2}$ ploto. 

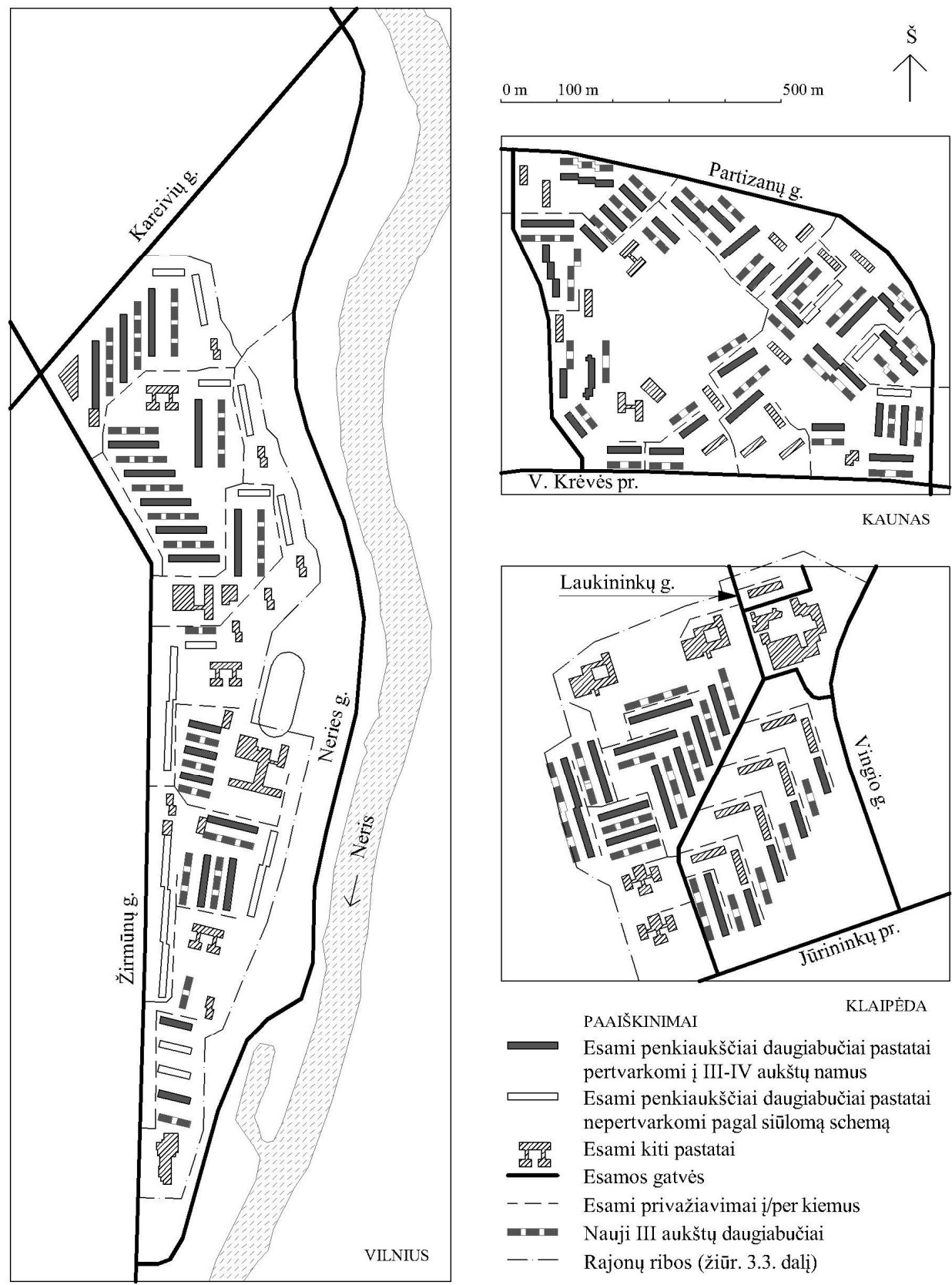

KAUNAS

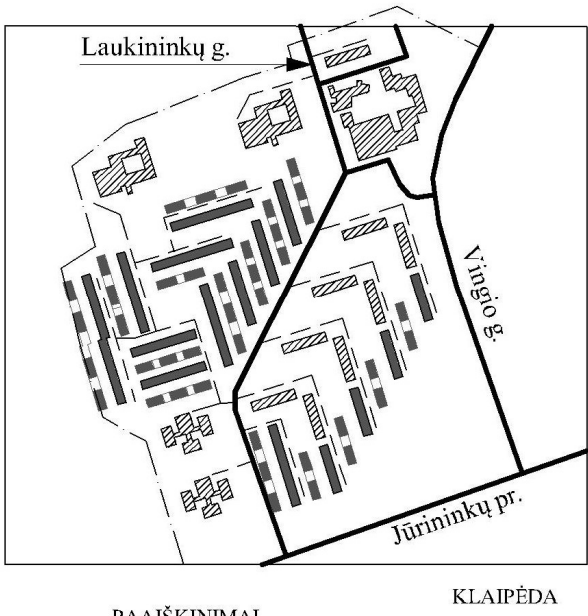

ש Esami penkiaukščiai daugiabučiai pastatai pertvarkomi ị III-IV aukštu namus

Esami penkiaukščiai daugiabučiai pastatai nepertvarkomi pagal siūlomą schemą

Esami kiti pastatai

Esamos gatvès

- - - Esami privažiavimai ị/per kiemus

- Nauji III aukštų daugiabučiai

- - Rajony ribos (žiūr. 3.3. dalị)

3.13 pav. Miestų rajonų schemos po dalinio perplanavimo

Fig. 3.13. Schemes of urban districts after partial replanning 
Pirmo aukšto plotas $-550 \mathrm{~m}^{2}$, todèl likusi erdvè $\left(150 \mathrm{~m}^{2}\right)$ galètų būti skirta smulkiai komercijai, namo bendro naudojimo patalpoms ir / arba dviračių saugykloms. Esant tinkamai teisinei bazei, galima svarstyti automobilių stovejjimo vietų skaičiaus didinimą ir vietas skirti gretimų namų gyventojams.

Skaičiuojant atliktų pertvarkymų galutinę emisiją, ji būtų sudaryta iš: senos statybos 42 butų daugiabučio, naujo 20 butų pastato ir papildomo šildomo ploto naujo pastato pirmame aukšte. Ši emisija būtų suminè, tačiau neobjektyviai parodytų galimus sutaupymus, nes įtrauktų 2 papildomus butus naujakuriams ir pirmo aukšto (komercinį) plotą. Atmetus šiuos dydžius iš suminès emisijos, būtų nustatyta reikalinga (lyginamoji) emisija.

Planavimo praktikoje nèra ịprasta skaičiuoti statistiniais daugiabučiais, todèl emisiją tikslinga sieti su butu ir / arba gyventoju skaičiumi (1.1. lentelè, I.4 parametras). Remiantis statistiniais duomenimis (LSD 2011b), bute gyvena vidutiniškai 2,2 gyventojo, tokiu atveju, atitinkamai pakeitus (3.5) formulę, gaunama teorinè vieno žmogaus, gyvenančio senos statybos daugiabutyje, emisija - $644 \mathrm{~kg} \mathrm{CO}_{2}$ ekvivalento ((3.6) formulè). Po pertvarkymo 42 butų name gyventų 92,4 žmogaus ir tai atitiktų $59518 \mathrm{~kg} \mathrm{CO}_{2}$ ekvivalento per metus:

$$
E_{2}=\frac{E_{1}}{2,2 f},
$$

čia $E_{2}$ - emisija, išreikšta $\mathrm{kg} \mathrm{CO}_{2}$ ekvivalento per metus (šildymo sezoną), $f$ butų skaičius name.

Naujas daugiabutis pagal suvartojamą šilumos kieki priskiriamas II kategorijai: vidutinis šilumos suvartojimas šildymui siekia apie $15 \mathrm{kWh} / \mathrm{m}^{2}$ per mènesi (LSTA 2012). Pakeitus $S, \lambda$ ir $f$ reikšmes (3.5) ir (3.6) formulèse, gauta naujo daugiabučio vieno gyventojo suminè emisija - $535 \mathrm{~kg} \mathrm{CO}_{2}$ ekvivalento, o lyginamoji emisija (skaičiuojant 18 butu ir atmetus plotą pirmame aukšte) mažesnè - $471 \mathrm{~kg} \mathrm{CO}_{2}$ ekvivalento. Atitinkamai viso projektuojamo daugiabučio suminè emisija būtu $23531 \mathrm{~kg} \mathrm{CO}_{2}$ ekvivalento ir lyginamoji emisija - $18637 \mathrm{~kg} \mathrm{CO}_{2}$ ekvivalento.

Po atliktų pertvarkymų galutinè emisija būtų: 1) $83049 \mathrm{~kg} \mathrm{CO}_{2}$ ekvivalento (suminè emisija) arba 2) $78155 \mathrm{~kg} \mathrm{CO}_{2}$ ekvivalento (lyginamoji emisija). Suminé emisija yra beveik tokia pati kaip ir seno daugiabučio (mažesnè $2 \%$ ), todèl pirmas ịspūdis, jog pokyčiai nèra efektyvūs, gali būti apgaulingas. Visų pirma, emisija skaičiuota atmetant „biudžeto“ sampratą, ir tai yra realus emisijos mažèjimas. Suminè emisija apima ne tik didesni komfortą, bet ir papildomus butus, tačiau vis tiek yra mažesnè už buvusią iki pertvarkymų (85026 kg $\mathrm{CO}_{2}$ ekvivalento). Lyginamoji emisija rodo tikslesni pokyti, kuris yra dar didesnis ir siekia $8 \%$. Vadinasi, vien tik daugiabučiu perplanavimo priemone leistų pasiekti nustatytą pirmą tikslą (2.5 pav.). Atsižvelgiant i ES svarstomą $30 \%$ scenarijų, minèti $8 \%$ galètų ženkliai prisidèti prie priemonių, reikalingų miestų 
bendruosiuose planuose mažinant emisijas nuo $20 \%$ iki $30 \%$. Vertinant rezultatus, reikia atsižvelgti i faktą, kad sprendimo netiesioginè itaka tiek miesto, tiek nacionaliniu lygiu būtų smarkiai didesnè: stabdoma miestų teritorinè plètra, išnaudojamos jau apgyvendintos teritorijos, esama inžinerine ir susisiekimo infrastruktūros, gerinamos esamos gyvenimo sąlygos. Suplanuoti 2 butai naujakuriams leistų atsisakyti (ar bent pasiūlyti alternatyvą) dviejų gyvenamujjų namų priemiesčiuose nuo kiekvieno 60 butų daugiabučio, t. y. pastebimai sumažinti emisiją, generuojamą kasdienių kelionių ir didesnio šildomo ploto individualiuose namuose. Be to, būtina atsižvelgti ị socialinị aspektą - vertinant iš gyventojų, kurie sutiktų persikelti, perspektyvos, nauji namai būtų komfortiškesni, butai - erdvesni, o skaičiuojamosios šildymo energijos sąnaudos būtų mažesnès beveik $30 \%$, todèl atitinkamai mažètų buto išlaikymo kaina. Gyventojai, kurie liktų gyventi senos statybos daugiabutyje, tiesiogiai nei išloštų, nei praloštų, tačiau netiesioginiai pokyčiai turètų būti vertinami teigiamai: namo aukštingumo sumažejjimas, mažesnis kaimynų skaičius laiptinejje, o gyvenantys ketvirtame aukšte, priklausomai nuo architektūrinio sprendimo, galètų naudotis terasomis. Galų gale gyventojai planuojant būtų vertinami ne tik ekonominiu aspektu, bet iš tikrujų jiems būtų pasiūlytos gyvenimo sąlygos artimesnès ES standartams. Apibendrinti pertvarkymų skaitiniai rezultatai pateikti 3.8 lentelèje.

3.8 lentelè. Pokyčiai, susiję su daliniu perplanavimu

Table 3.8. Changes due to partial replanning

\begin{tabular}{|c|c|c|c|c|c|}
\hline Pastatas & $\begin{array}{l}\text { Butu } \\
\text { skai- } \\
\text { čius, } \\
\text { vnt. }\end{array}$ & $\begin{array}{l}1 \text { gyventojo } \\
\text { emisija, } \\
\mathrm{kg} \mathrm{CO}_{2} \\
\text { ekvivalento }\end{array}$ & $\begin{array}{l}\text { Bendra pastato } \\
\text { emisija, } \\
\mathrm{kg} \mathrm{CO}_{2} \\
\text { ekvivalento }\end{array}$ & \multicolumn{2}{|c|}{$\begin{array}{l}\text { Emisijos sumažejimas } \\
\text { lyginant su senos } \\
\text { statybos daugiabučiu, } \\
\%\end{array}$} \\
\hline $\begin{array}{l}\text { Senos } \\
\text { statybos } \\
\text { daugiabutis }\end{array}$ & 60 & 644 & 85026 & \multicolumn{2}{|l|}{-} \\
\hline $\begin{array}{l}\text { Senos } \\
\text { statybos } \\
\text { daugiabutis } \\
\text { sumažinus } \\
\text { butu skaičių }\end{array}$ & 42 & 644 & 59518 & \multirow[t]{3}{*}{$2^{*}$} & \multirow[t]{3}{*}{$8 * *$} \\
\hline \multirow{2}{*}{$\begin{array}{l}\text { Naujas } \\
\text { daugiabutis }\end{array}$} & \multirow[t]{2}{*}{20} & $535^{*}$ & $23531 *$ & & \\
\hline & & $471 * *$ & $18637 * *$ & & \\
\hline
\end{tabular}

Pastabos: * suminė emisija, ${ }^{* *}$ lyginamoji emisija 


\subsection{Energetikos sektoriaus pertvarkymų poveikio išorinei miesto ekologijai daugiakriteris vertinimas}

3.2 poskyryje pristatytas siūlymas, kaip energetikos sektorių integruoti ị miestų planavimo praktiką. Siūlomuose skaičiavimų modeliuose naudojami miestų planavimui aktualūs parametrai, kurie matuojami ivvairiais vienetais ir kurių siektinosios vertès dažnai yra priešingos, pavyzdžiui, augantis rajono gyventojų skaičius yra teigiamas reiškinys, tačiau, didinant pastatais užstatomą plotą, mažinamas rajone esančių želdynų plotas. Palyginti disertacijoje analizuotas miestų rajonų dalis (Vilniaus, Kauno ir Klaipedos), langų keitimo variantus ir nustatyti optimalu variantą, 3.3 poskyryje taikomi daugiakriterio vertinimo metodai. Sprendžiami trys uždaviniai: pirmojo tikslas įvertinti Vilniaus, Kauno ir Klaipedos rajonų dalių esamą situaciją pagal 1.4 poskyryje atrinktus kiekybinius LR įstatymuose apibrezžtus parametrus (1.1 lentelè), antrojo - tas pačias rajonų dalis ịvertinti po siūlomų pertvarkymų ir trečiojo - parinkti optimalų langu keitimo variantą (Staniūnas et al. 2013). Nustatant kriterijų siektinąsias vertes (ar verte turi būti didesnè, ar mažesnè), remiamasi bendrąja planavimo praktika, t. y. vertinama iš miestų planuotojų (specialistų) pozicijos. Uždaviniuose ịtraukiamas išorinès miesto ekologijos dèmuo: metinè emisija, susidaranti dèl energetinių (šildymo) poreikių. Skaičiuojant pradinius duomenis, Vilniaus rajono dalis dèl specifiniu gamtinių sąlygu (reljefas ir upès slènis) buvo apribota (sumažinta) nuo upès pusès (3.13 pav.). Minètas teritorinis „apkarpymas“ leido suvienodinti išeities duomenis, kitu atveju Vilniaus rajono dalis būtų netikslingai ir statistiškai neteisingai išsiskyrusi iš kitų.

3.9 lentelè. Sprendimu prièmimu matrica $\mathrm{P} 1 \mathrm{e}$

Table 3.9. Decision making matrix $P 1 \mathrm{e}$

\begin{tabular}{|l|l|l|l|l|l|l|}
\hline $\begin{array}{l}\text { Vari- } \\
\text { antas }\end{array}$ & $\begin{array}{l}\text { Užstaty- } \\
\text { mo aukštis } \\
\text { be cokolio, } \\
\mathrm{m}\end{array}$ & $\begin{array}{l}\text { Užstatymo } \\
\text { intensyvu- } \\
\text { mas, } \\
\%\end{array}$ & $\begin{array}{l}\text { Užstaty- } \\
\text { mo } \\
\text { tankumas, } \\
\%\end{array}$ & $\begin{array}{l}\text { Gyven- } \\
\text { tojų } \\
\text { skaičius, } \\
\text { vnt. }\end{array}$ & $\begin{array}{l}\text { Želdy- } \\
\text { nų } \\
\text { plotas, } \\
\mathrm{m}^{2}\end{array}$ & $\begin{array}{l}\text { Metine } \\
\text { emisija, } \\
\text { t CO }_{2} \\
\text { ekvivalento }\end{array}$ \\
\cline { 2 - 7 } & $x_{1}$ & $x_{2}$ & $x_{3}$ & $x_{4}$ & $x_{5}$ & $x_{6}$ \\
\hline$q_{j}$ & $\min$ & $\max$ & $\max$ & $\max$ & $\max$ & $\min$ \\
\hline $\mathrm{A}_{\mathrm{e}-\mathrm{vno}}$ & 15,400 & 61 & 0,167 & 0,166 & 0,167 & 0,167 \\
\hline $\mathrm{A}_{\mathrm{e}-\mathrm{kun}}$ & 16,200 & 54 & 15 & 8296 & 51912 & 5343 \\
\hline $\mathrm{A}_{\mathrm{e}-\mathrm{klp}}$ & 12,000 & 50 & 11 & 7806 & 105648 & 5027 \\
\hline
\end{tabular}

Pastaba: $\mathrm{OK}^{*}$ - optimizavimo kryptis 
Esama rajonų dalių būklè buvo išreikšta diskretiniais dydžiais ir sudaryta pradinė sprendimų prièmimų matrica $\mathrm{P} 1 \mathrm{e}$, skirta pirmojo uždavinio sprendimui (3.9 lentelè). Eilutès $-\mathrm{A}_{\mathrm{e}-\mathrm{nno}}, \mathrm{A}_{\mathrm{e}-\mathrm{kun}}$ ir $\mathrm{A}_{\mathrm{e}-\mathrm{klp}}-$ žymi analizuojamus variantus: Vilniaus, Kauno ir Klaipédos miestų rajonų dalis. Stulpeliai skirti rodikliams $(x)$, iš kurių $x_{1}-x_{5}$ atrinkti iš 1.1 lentelès, o $x_{6}$ skirtas išorinei miesto ekologijai vertinti. Rodikliai sudaryti remiantis LR planavimo istatymais, istatymuose svarba (prioritetas) neapibrèžti, todèl visiems rodikliams suteikiamas vienodas reikšmingumas $\left(q_{j}\right)$. Uždavinyje nagrinejami 3 variantai $(m)$, kurie aprašomi 6 rodikliais $(n)$.

3.10 lentelè. Sprendimų prièmimų matrica $\mathrm{P} 1 \mathrm{p}$

Table 3.10. Decision making matrix P1p

\begin{tabular}{|c|c|c|c|c|c|c|}
\hline $\begin{array}{l}\text { Vari- } \\
\text { antas }\end{array}$ & $\begin{array}{l}\text { Atstumas } \\
\text { tarp esamų } \\
\text { ir naujų } \\
\text { pastatur, } \\
\text { m }\end{array}$ & $\begin{array}{l}\text { Užstaty- } \\
\text { mo } \\
\text { intensy- } \\
\text { vumas, } \\
\%\end{array}$ & $\begin{array}{l}\text { Užstaty- } \\
\text { mo } \\
\text { tanku- } \\
\text { mas, } \\
\%\end{array}$ & $\begin{array}{l}\text { Gyventojų } \\
\text { skaičius } \\
\text { senuose } \\
\text { pastatuose, } \\
\text { vnt. }\end{array}$ & $\begin{array}{l}\text { Gyventojų } \\
\text { skaičius } \\
\text { naujuose } \\
\text { pastatuose, } \\
\text { vnt. }\end{array}$ & $\begin{array}{l}\text { Metinè } \\
\text { emisija, } \\
\mathrm{t} \mathrm{CO}_{2} \\
\text { ekviva- } \\
\text { lento }\end{array}$ \\
\hline & $x_{1}$ & $x_{2}$ & $x_{3}$ & $x_{4}$ & $x_{5}$ & $x_{6}$ \\
\hline $\mathrm{OK}^{*}$ & $\max$ & $\max$ & $\max$ & $\min$ & $\max$ & $\min$ \\
\hline$q_{j}$ & 0,167 & 0,166 & 0,167 & 0,166 & 0,167 & 0,167 \\
\hline $\begin{array}{l}\mathrm{A}_{\mathrm{p}-\mathrm{vno}} \\
{[w ; b]}\end{array}$ & {$[11 ; 13]$} & {$[60 ; 68]$} & {$[17 ; 21]$} & $\begin{array}{l}{[4942 ;} \\
6178]\end{array}$ & $\begin{array}{l}{[1390 ;} \\
1737]\end{array}$ & $\begin{array}{l}{[3837 ;} \\
4797]\end{array}$ \\
\hline $\begin{array}{l}\mathrm{A}_{\mathrm{p}-\mathrm{kun}} \\
{[w ; b]}\end{array}$ & {$[12 ; 14]$} & {$[54 ; 62]$} & {$[16 ; 20]$} & $\begin{array}{l}{[5888 ;} \\
7360]\end{array}$ & $\begin{array}{l}{[1758 ;} \\
2197]\end{array}$ & $\begin{array}{l}{[4620 ;} \\
5775]\end{array}$ \\
\hline $\begin{array}{l}\mathrm{A}_{\mathrm{p}-\mathrm{klp}} \\
{[w ; b]}\end{array}$ & {$[11 ; 20]$} & {$[49 ; 57]$} & {$[16 ; 20]$} & $\begin{array}{l}{[3876} \\
4845]\end{array}$ & $\begin{array}{l}{[1232 ;} \\
1540]\end{array}$ & $\begin{array}{l}{[3076 ;} \\
3845]\end{array}$ \\
\hline
\end{tabular}

Pastaba: $\mathrm{OK}^{*}-$ optimizavimo kryptis

Po siūlomų pertvarkymų rajonai vertinami iš esmès pagal tuos pačius parametrus, išskyrus užstatymo aukštị ir želdynų plotą. Aukštis atmetamas, nes po pertvarkymų visų rajonų aukštingumas sumažès, viena iš pertvarkymo idejjų yra rajonų aukštingumo mažinimas (3.12 pav.). Želdynų plotas atmetamas, nes po pertvarkymu jis paliekamas toks pats, pertvarkymai orientuoti ị naują statybą, ją ịterpiant tarp esamų statinių, o ne mažinant želdynų skaičių. Aukščio parametras keičiamas atstumo tarp esamų ir projektuojamu pastatų rodikliu, o želdynų rodiklis - gyventojų, apsigyvensiančių naujuose pastatuose, skaičiumi. Bendrabučiuose ar bendrabučio tipo pastatuose gyvenantys žmonès i skaičiavimus neįtraukiami, nes šis pastatų tipas būdingas tarybiniam laikotarpiui 
ir nebeatitinkantis šių laikų gyvenimo kokybès standartų ir normų, be to, šio tipo būstams būdingos socialinès problemos. Galutinių pertvarkymo rezultatų negalima išreikšti konkrečias skaitines reikšmes turinčiais rodikliais, todèl naudojami pilkieji skaičiai, kurie sudaro pradinę sprendimų prièmimų matricą

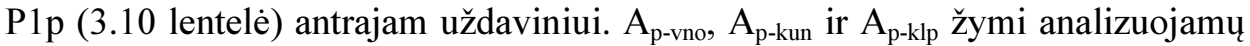
miestų - atitinkamai Vilniaus, Kauno ir Klaipèdos - rajonų dalis po siūlomo perplanavimo.

Trečiojo uždavinio pradinę sprendimų prièmimu matricą, kaip ir pirmojo uždavinio atveju, sudaro diskretiniai dydžiai, pradinè sprendimų prièmimų matrica P1pvc pateikta 3.11 lentelëje. Uždavinyje nagrinèjami 5 variantai $(\mathrm{m})$, kurie aprašomi 5 rodikliais $(n)$.

3.11 lentelè. Sprendimų prièmimų matrica $\mathrm{P} 1 \mathrm{pvc}$

Table 3.11. Decision making matrix P1pvc

\begin{tabular}{|l|l|l|l|l|l|}
\hline Variantas & $\begin{array}{l}\text { Šilumos } \\
\text { perdavimo } \\
\text { koeficientas, } \\
\mathrm{W} / \mathrm{m}^{2} \mathrm{~K}\end{array}$ & $\begin{array}{l}\text { Kaina, } \\
\mathrm{LTL} / \mathrm{m}^{2}\end{array}$ & $\begin{array}{l}\text { Metines } \\
\text { energijos } \\
\text { sąnaudos, } \\
\mathrm{kW} / \mathrm{m}^{2}\end{array}$ & $\begin{array}{l}\text { Metiniai } \\
\text { šilumos } \\
\text { nuostoliai, } \\
\mathrm{kWh}\end{array}$ & $\begin{array}{l}\text { Metine } \\
\text { emisija, } \\
\mathrm{kg} \mathrm{CO} \\
\text { ekvivalento }\end{array}$ \\
\hline$x_{1}$ & $x_{2}$ & $x_{3}$ & $x_{4}$ & $x_{5}$ \\
\hline $\mathrm{OK}^{*}$ & $\min$ & $\min$ & Min & $\min$ & min \\
\hline$q_{j}$ & 0,200 & 0,200 & 0,200 & 0,200 & 0,200 \\
\hline $\mathrm{A}_{\text {esamas }}$ & 2,500 & 80 & 56,560 & 153278 & 38473 \\
\hline $\mathrm{A}_{1}$ & 1,000 & 320 & 22,630 & 61327 & 15393 \\
\hline $\mathrm{A}_{2}$ & 0,700 & 377 & 15,840 & 42926 & 10774 \\
\hline $\mathrm{A}_{3}$ & 0,600 & 403 & 13,580 & 36802 & 9237 \\
\hline $\mathrm{A}_{4}$ & 0,500 & 429 & 11,310 & 30650 & 7693 \\
\hline$\sum$ & 5,300 & 1609 & 119,920 & 324983 & 81570 \\
\hline opt & 0,500 & 80 & 11,310 & 30650 & 7693 \\
\hline
\end{tabular}

Pastabos: $A_{\text {esamas }}-A_{4}$ atitinka „Esamas“, „1“, „2“, ,3“ ir „4“" variantus iš 3.1 lentelès. optoptimali rodiklio verte. $\mathrm{OK}^{*}$ - optimizavimo kryptis

Pirmojo uždavinio sprendimui parinkti trys plačiai taikomi daugiakriteriai vertinimo metodai: SAW, TOPSIS ir COPRAS (Chen 2012; Dymova et al. 2013; Zavadskas et al. 2008; Zavadskas et al. 2012).

Pirmas SAW metodo etapas - sprendimo priemimo matricos P1e (3.9 lentelè) normalizavimas, jei pageidaujama didesnè rodiklio reikšmė (max), 
normalizavimas atliekamas remiantis (3.7) formule, jei mažesnè (min) - (3.8) formulè:

$$
\begin{gathered}
\bar{x}_{i j}=\frac{x_{i j}}{x_{j}^{\max }} ; \\
\bar{x}_{i j}=\frac{x_{j}^{\min }}{x_{i j}} .
\end{gathered}
$$

Remiantis (3.7) ir (3.8) formulèmis, sudaryta SAW normalizuota sprendimu prièmimų matrica P1e (3.12 lentelè).

3.12 lentelè. SAW normalizuota sprendimų prièmimų matrica P1e

Table 3.12. SAW normalised decision making matrix P1e

\begin{tabular}{|l|l|l|l|l|l|l|}
\hline Variantas & $\bar{x}_{1}$ & $\bar{x}_{2}$ & $\bar{x}_{3}$ & $\bar{x}_{4}$ & $\bar{x}_{5}$ & $\bar{x}_{6}$ \\
\hline $\mathrm{A}_{\text {e-vno }}$ & 0,779 & 1,000 & 1,000 & 1,000 & 0,491 & 0,638 \\
\hline $\mathrm{A}_{\mathrm{e}-\text { kun }}$ & 0,741 & 0,885 & 0,733 & 0,941 & 1,000 & 0,678 \\
\hline $\mathrm{A}_{\text {e-klp }}$ & 1,000 & 0,820 & 0,867 & 0,638 & 0,751 & 1,000 \\
\hline
\end{tabular}

Antras SAW metodo etapas - normalizuotos sprendimų prièmimų matricos P1e kiekvieno normalizuoto rodiklio sandauga su rodiklio santykiniu reikšmingumu ir sudejjimas su kitais varianto rodikliais (3.13 lentelè). Etapas aprašomas (3.9) formule:

$$
S_{i}=\sum_{j=1}^{n} \bar{x}_{i j} q_{j}
$$

3.13 lentelè. SAW normalizuota svertinè sprendimų prièmimų matrica P1e

Table 3.13. SAW weighted and normalised decision making matrix P1e

\begin{tabular}{|l|l|l|l|l|l|l|l|}
\hline Variantas & $\overline{\bar{x}}_{1}$ & $\overline{\bar{x}}_{2}$ & $\overline{\bar{x}}_{3}$ & $\overline{\bar{x}}_{4}$ & $\overline{\bar{x}}_{5}$ & $\overline{\bar{x}}_{6}$ & $S_{i}$ \\
\hline $\mathrm{A}_{\text {e-vno }}$ & 0,130 & 0,166 & 0,167 & 0,166 & 0,082 & 0,106 & 0,818 \\
\hline $\mathrm{A}_{\text {e-kun }}$ & 0,124 & 0,147 & 0,122 & 0,156 & 0,167 & 0,113 & 0,829 \\
\hline $\mathrm{A}_{\text {e-klp }}$ & 0,167 & 0,136 & 0,145 & 0,106 & 0,125 & 0,167 & 0,846 \\
\hline
\end{tabular}


Paskutinis SAW metodo etapas - prioritetu eilès sudarymas, remiantis surinktų balų skaičiumi, ir optimalaus (daugiausiai balų gavusio) varianto nustatymas. Gauta tokia prioritetų eilè: $A_{e-k l p}, A_{e-k u n}$ ir $A_{e-v n o}$, t. y. geriausia esamos būklè yra analizuotoje Klaipédos rajono dalyje, prastesné Kauno ir prasčiausia Vilniuje. Skirtumas tarp Kauno ir Vilniaus yra mažesnis nei bet kurio iš šių miestų, juos lyginant su Klaipeda.

TOPSIS metodo esmè - nustatyti, kuris variantas yra arčiausiai idealaus ir toliausiai nuo prasčiausio varianto. Pirmas TOPSIS metodo etapas - sprendimo prièmimo matricos P1e (3.9 lentelè) normalizavimas, kuris atliekamas pagal (3.10) formulę:

$$
\bar{x}_{i j}=\frac{x_{i j}}{\sqrt{\sum_{i=1}^{m} x_{i j}^{2}}} .
$$

Remiantis (3.10) formule, sudaryta TOPSIS normalizuota sprendimu prièmimų matrica P1e (3.14 lentelè).

3.14 lentelè. TOPSIS normalizuota sprendimų prièmimų matrica P1e Table 3.14. TOPSIS normalised decision making matrix P1e

\begin{tabular}{|l|l|l|l|l|l|l|}
\hline Variantas & $\bar{x}_{1}$ & $\bar{x}_{2}$ & $\bar{x}_{3}$ & $\bar{x}_{4}$ & $\bar{x}_{5}$ & $\bar{x}_{6}$ \\
\hline $\mathrm{A}_{\text {e-vno }}$ & 0,607 & 0,638 & 0,661 & 0,661 & 0,366 & 0,661 \\
\hline $\mathrm{A}_{\text {e-kun }}$ & 0,639 & 0,565 & 0,485 & 0,622 & 0,744 & 0,621 \\
\hline $\mathrm{A}_{\text {e-klp }}$ & 0,473 & 0,523 & 0,573 & 0,421 & 0,559 & 0,421 \\
\hline
\end{tabular}

Antras TOPSIS metodo etapas - normalizuotos svertinès sprendimo prièmimo matricos P1e sudarymas. Šiame etape kiekvienas normalizuotos sprendimų prièmimų matricos (3.14 lentelè) rodiklis dauginamas iš atitinkamo rodiklio reikšmingumo, rezultatai pateikti 3.15 lenteleje.

3.15 lentelè. TOPSIS normalizuota svertiné sprendimų prièmimų matrica P1e Table 3.15. TOPSIS weighted and normalised decision making matrix P1e

\begin{tabular}{|l|l|l|l|l|l|l|}
\hline Variantas & $\overline{\bar{x}}_{1}$ & $\overline{\bar{x}}_{2}$ & $\overline{\bar{x}}_{3}$ & $\overline{\bar{x}}_{4}$ & $\overline{\bar{x}}_{5}$ & $\overline{\bar{x}}_{6}$ \\
\hline $\mathrm{A}_{\text {e-vno }}$ & 0,101 & 0,106 & 0,110 & 0,110 & 0,061 & 0,110 \\
\hline $\mathrm{A}_{\text {e-kun }}$ & 0,107 & 0,094 & 0,081 & 0,103 & 0,124 & 0,104 \\
\hline $\mathrm{A}_{\text {e-klp }}$ & 0,079 & 0,087 & 0,096 & 0,070 & 0,093 & 0,070 \\
\hline
\end{tabular}


Trečiame TOPSIS metodo etape pagal 3.15 lentelę sudaromi idealus teigiamas $A^{+}$((3.11) formulè) ir idealus neigiamas $A^{-}$((3.12) formulè) variantai:

$$
\begin{aligned}
& A^{+}=\left\{\left(\max _{i} \overline{\bar{x}}_{i j} \mid j \in J\right),\left(\min _{i} \overline{\bar{x}}|j| j \in J^{\prime}\right), i=\overline{1, m}\right\}=\left\{\overline{\overline{x_{1}^{+}}}, \overline{\overline{x_{2}^{+}}}, \ldots \overline{\overline{x_{n}^{+}}}\right\} ; \\
& A^{+}=\{0,079 ; 0,106 ; 0,110 ; 0,110 ; 0,124 ; 0,070\} \text {; } \\
& A^{-}=\left\{\left(\min _{i} \bar{x}_{i j} \mid j \in J\right),\left(\max _{i} \bar{x}_{i j} \mid j \in J^{\prime}\right), i=\overline{1, m}\right\}=\left\{\overline{\overline{x_{1}^{-}}}, \overline{\overline{x_{2}^{-}}}, \ldots \overline{\overline{x_{n}^{-}}}\right\} ; \\
& A^{-}=\{0,107 ; 0,087 ; 0,081 ; 0,070 ; 0,061 ; 0,110\} \text {. }
\end{aligned}
$$

Ketvirtas TOPSIS metodo etapas skirtas atstumo iki idealaus (teigiamo ir neigiamo) sprendinio apskaičiuoti. Konkretaus varianto atstumas iki idealaus teigiamo sprendinio skaičiuojamas pagal (3.13) formulę, o atstumas iki idealaus neigiamo - pagal (3.14) formulę, rezultatai pateikti 3.16 lentelèje.

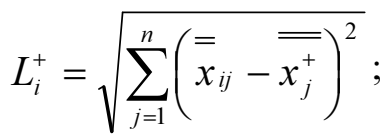

$$
\begin{aligned}
& L_{i}^{-}=\sqrt{\sum_{j=1}^{n}\left(\overline{x_{i j}-\overline{x_{j}^{-}}}\right)^{2}} \text {. }
\end{aligned}
$$

3.16 lentelè. Variantų atstumai iki idealaus teigiamo ir idealaus neigiamo sprendinio Table 3.16. Distance between a particular variant and the best and the worst conditions

\begin{tabular}{|l|l|l|}
\hline Variantas & $L_{i}^{+}$ & $L_{i}^{-}$ \\
\hline $\mathrm{A}_{\text {e-vno }}$ & 0,078 & 0,053 \\
\hline $\mathrm{A}_{\mathrm{e}-\mathrm{kun}}$ & 0,054 & 0,072 \\
\hline $\mathrm{A}_{\mathrm{e}-\mathrm{klp}}$ & 0,056 & 0,060 \\
\hline
\end{tabular}

Penktuoju TOPSIS metodo etapu, remiantis (3.15) formule, apskaičiuojamas santykinis atstumas iki idealaus sprendinio. Variantas, kurio $K_{i}$ yra arčiausiai vieneto, yra geriausias (3.17 lentelè).

$$
K_{i}=\frac{L_{i}^{-}}{L_{i}^{+}+L_{i}^{-}}, 0 \leq K_{i} \leq 1 .
$$


3.17 lentelè. TOPSIS santykiniai atstumai iki idealaus sprendinio

Table 3.17. TOPSIS similarity to the ideal solution

\begin{tabular}{|l|l|l|}
\hline Variantas & $K_{i}$ & Variantų prioritetai \\
\hline $\mathrm{A}_{\mathrm{e}-\mathrm{vno}}$ & 0,406 & 3 \\
\hline $\mathrm{A}_{\mathrm{e}-\mathrm{kun}}$ & 0,571 & 1 \\
\hline $\mathrm{A}_{\mathrm{e}-\mathrm{klp}}$ & 0,519 & 2 \\
\hline
\end{tabular}

Skaičiuojant TOPSIS metodu nustatyta, kad geriausia esama būklè yra analizuotoje Kauno rajono dalyje, prastesné Klaipèdos ir prasčiausia Vilniuje. Gauti TOPSIS rezultatai patvirtina, kad Vilniuje situacija yra prasčiausia, tačiau dèl Klaipedos ir Kauno rezultatu SAW ir TOPSIS atsakymai nesutapo, todèl uždavinys sprendžiamas trečiu (COPRAS) metodu.

Pirmas COPRAS metodo etapas - sprendimo prièmimo matricos P1e (3.9 lentelè) normalizavimas įtraukiant reikšmingumus, kuris atliekamas pagal (3.16) formulę:

$$
\bar{x}_{i j}=\frac{x_{i j} q_{j}}{\sum_{i=1}^{m} x_{i j}} .
$$

Remiantis (3.16) formule, sudaryta COPRAS normalizuota svertiné sprendimų prièmimų matrica P1e (3.18 lentelè).

3.18 lentelè. COPRAS normalizuota svertiné sprendimų prièmimų matrica P1e Table 3.18. COPRAS weighted and normalised decision making matrix Ple

\begin{tabular}{|l|l|l|l|l|l|l|}
\hline Variantas & $\overline{\bar{x}}_{1}$ & $\overline{\bar{x}}_{2}$ & $\overline{\bar{x}}_{3}$ & $\overline{\bar{x}}_{4}$ & $\overline{\bar{x}}_{5}$ & $\overline{\bar{x}}_{6}$ \\
\hline $\mathrm{A}_{\text {e-vno }}$ & 0,059 & 0,061 & 0,064 & 0,064 & 0,037 & 0,065 \\
\hline $\mathrm{A}_{\text {e-kun }}$ & 0,062 & 0,054 & 0,047 & 0,061 & 0,074 & 0,061 \\
\hline $\mathrm{A}_{\text {e-klp }}$ & 0,046 & 0,050 & 0,056 & 0,041 & 0,056 & 0,041 \\
\hline
\end{tabular}

Antruoju metodo etapu remiantis, COPRAS normalizuota svertine sprendimų prièmimų matrica P1e (3.18 lentelè), sumuojamos maksimizuojamų ir minimizuojamų rodiklius vertès bei gaunamos variantus apibūdinančios sumos $S_{+i}$ bei $S_{-i}$ (3.19 lentelè). 
3.19 lentelè. Maksimizuojamos ir minimizuojamos rodiklių sumos $S_{+i}$ ir $S_{-i}$

Table 3.19. Maximised and minimised indicators sums $S_{+i}$ and $S_{-i}$

\begin{tabular}{|l|l|l|}
\hline Variantas & $S_{+i}$ & $S_{-i}$ \\
\hline $\mathrm{A}_{\text {e-vno }}$ & 0,226 & 0,124 \\
\hline $\mathrm{A}_{\text {e-kun }}$ & 0,236 & 0,123 \\
\hline $\mathrm{A}_{\text {e-klp }}$ & 0,203 & $0,087^{*}$ \\
\hline
\end{tabular}

Pastaba: * žymi mažiausią $S_{-i}$ vertę $\mathrm{S}_{-m i n}$

Trečias COPRAS metodo etapas skirtas variantu prioritetams nustatyti. Prioritetų eiliškumas skaičiuojamas remiantis (3.17) formule, kuo $Q_{i}$ didesnis, tuo variantas yra geresnis:

$$
Q_{i}=S_{+i}+\frac{S_{-\min } \sum_{i=1}^{m} S_{-i}}{S_{-i} \sum_{i=1}^{m} \frac{S_{-\min }}{S_{-i}}} .
$$

Remiantis (3.17) formule, $Q_{\mathrm{e}-\mathrm{vno}}=0,323, Q_{\mathrm{e}-\mathrm{kun}}=0,334$ ir $Q_{\mathrm{e}-\mathrm{klp}}=0,342$, atitinkamai gaunama tokia prioritetu eilè: $A_{e-k l p}, A_{e-k u n}$ ir $A_{e-v n o}, t$. y. geriausia esamos būklè yra analizuotoje Klaipédos rajono dalyje, prastesnè Kauno ir prasčiausia Vilniuje.

3.20 lentelè. Galutiniai SAW, TOPSIS ir COPRAS rezultatai (P1e)

Table 3.20. Final SAW, TOPSIS and COPRAS results (P1e)

\begin{tabular}{|l|l|l|l|l|}
\hline Variantas & $\begin{array}{l}\text { Prioritetai } \\
\text { pagal SAW }\end{array}$ & $\begin{array}{l}\text { Prioritetai pagal } \\
\text { TOPSIS }\end{array}$ & $\begin{array}{l}\text { Prioritetai pagal } \\
\text { COPRAS }\end{array}$ & $\begin{array}{l}\text { Galutiniai } \\
\text { variantu prioritetai }\end{array}$ \\
\hline $\mathrm{A}_{\mathrm{e}-\mathrm{vno}}$ & 3 & 3 & 3 & 3 \\
\hline $\mathrm{A}_{\mathrm{e}-\mathrm{kun}}$ & 2 & 1 & 2 & 2 \\
\hline $\mathrm{A}_{\mathrm{e}-\mathrm{klp}}$ & 1 & 2 & 1 & 1 \\
\hline
\end{tabular}

Apibendrinti SAW, TOPSIS ir COPRAS skaičiavimų rezultatai pateikti 3.20 lenteleje, iš jos matyti, kad visais atvejais Vilniaus rajono dalies rezultatai yra blogiausi, o Kauno ir Klaipèdos situacija geresnè. Dviem - SAW ir COPRAS - iš trijų metodu gauti identiški rezultatai, todèl priimama, kad šiais metodais nustatyta prioritetų eilè yra korektiška: geriausia situacija, vertinant esamą būklę pagal pirmame uždavinyje nurodytus rodiklius, yra Klaipėdos rajono dalyje. Verta pabrěžti, kad skaičiavimais nustatyti matematiškai 
optimalūs variantai, o realiame gyvenime ne mažiau svarbūs yra faktiniai skirtumai, kurie, atsižvelgiant i rezultatus, yra labai nežymūs. Sovietinis planavimas pasižymejjo griežtais normatyvais, kurie buvo akivaizdžiai tiksliai ir vienodai igyvendinti visuose analizuotuose miestuose. Ar situacija pasikeistų po siūlomo perplanavimo, parodys antrojo uždavinio rezultatai.

Antrojo uždavinio sprendimui naudojami tie patys daugiakriteriai metodai kaip ir pirmojo uždavinio sprendimui, tačiau metodai pritaikyti intervaliniams pilkiesiems duomenims. Pilkujų sistemų teorija taikoma nuo devinto dešimtmečio (pristatyta Deng $1982 \mathrm{~m}$.) ir nuo to laiko sparčiai išpopuliarejjo dèl išskirtinès galimybès spręsti uždavinius, kai rodikliai nèra galutinai apibrèžti (Kayacan et al. 2010; Zavadskas et al. 2010a; Yin 2013). Ilgainiui pilkujuc sistemu teorija pradèta taikyti ekonomikos, finansų, technologijos, geologijos, socialiniuose ir pan. moksluose, nors pastebima, kad teorija daugiau demesio sulaukè rytu (Australija, Taivanas, Japonija), o ne vakarų valstybėse (Kayacan et al. 2010; Yin 2013). Prilyginus spalvoms, pilkoji sistema užima tarpinę padètį: juodasis dydis reprezentuoja situaciją, kai sistemos parametrai yra visiškai nežinomi, o baltasis priešingai - kai visi procesai yra apibrežti ir aiškūs, taigi pilkoji sistema turi ir žinomų, ir nežinomų verčių (Kayacan et al. 2010; Zavadskas et al. 2010a). Antrajam uždaviniui taikomi pilkųjų sistemų metodai yra šie: 1) SAW-G, 2) TOPSIS grey ir 3) COPRAS-G (Zavadskas et al. 2008; Zavadskas et al. 2010a; Zavadskas et al. 2010b).

Pirmas SAW-G metodo etapas - sprendimo prièmimo matricos P1p (3.10 lentelè) normalizavimas, jei pageidaujama didesnè rodiklio reikšmé (max), normalizavimas atliekamas remiantis (3.18) formule, jei mažesnè (min) - (3.19) formule:

$$
\begin{aligned}
& \bar{w}_{i j}=\frac{w_{i j}}{\max _{i} b_{i j}} ; \bar{b}_{i j}=\frac{b_{i j}}{\max _{i} b_{i j}} ; \\
& \bar{w}_{i j}=\frac{\min _{i} w_{i j}}{w_{i j}} ; \bar{b}_{i j}=\frac{\min _{i} w_{i j}}{b_{i j}} .
\end{aligned}
$$

Remiantis (3.18) ir (3.19) formulèmis, sudaryta SAW-G normalizuota sprendimų prièmimų matrica P1p (3.21 lentelè). 
3.21 lentelè. SAW-G normalizuota sprendimų priėmimų matrica P1p

Table 3.21. SAW-G normalised decision making matrix P1p

\begin{tabular}{|l|l|l|l|l|l|l|l|}
\hline \multicolumn{2}{|l|}{ Variantas } & $\bar{x}_{1}$ & $\bar{x}_{2}$ & $\bar{x}_{3}$ & $\bar{x}_{4}$ & $\bar{x}_{5}$ & $\bar{x}_{6}$ \\
\hline \multirow{2}{*}{$\mathrm{A}_{\mathrm{p} \text {-vno }}$} & $\bar{w}$ & 0,550 & 0,882 & 0,810 & 0,784 & 0,633 & 0,802 \\
\cline { 2 - 8 } & $\bar{b}$ & 0,650 & 1,000 & 1,000 & 0,627 & 0,791 & 0,641 \\
\hline \multirow{2}{*}{$\mathrm{A}_{\mathrm{p}-\text { kun }}$} & $\bar{w}$ & 0,600 & 0,794 & 0,762 & 0,658 & 0,800 & 0,666 \\
\cline { 2 - 8 } & $\bar{b}$ & 0,700 & 0,912 & 0,952 & 0,527 & 1,000 & 0,533 \\
\hline \multirow{2}{*}{$\mathrm{A}_{\mathrm{p} \text {-klp }}$} & $\bar{w}$ & 0,550 & 0,721 & 0,762 & 1,000 & 0,561 & 1,000 \\
\cline { 2 - 8 } & $\bar{b}$ & 1,000 & 0,838 & 0,952 & 0,800 & 0,701 & 0,800 \\
\hline
\end{tabular}

Antras SAW-G metodo etapas - normalizuotos sprendimu prièmimu matricos P1p kiekvieno varianto sandauga su reikšmingumu (3.22 lentelè) ir variantų balų sumų skaičiavimas. Balų sumos skaičiuojamos pagal (3.20) formulę:

$$
L_{i}=\frac{1}{m} \sum_{j=1}^{n} \frac{\bar{w}_{i j}+\overline{\bar{b}}_{i j}}{2} .
$$

3.22 lentelè. SAW-G normalizuota svertinè sprendimų prièmimų matrica P1p

Table 3.22. SAW-G weighted and normalised decision making matrix P1p

\begin{tabular}{|l|l|l|l|l|l|l|l|l|}
\hline \multicolumn{2}{|l|}{ Variantas } & $\overline{\bar{x}}_{1}$ & $\overline{\bar{x}}_{2}$ & $\overline{\bar{x}}_{3}$ & $\overline{\bar{x}}_{4}$ & $\overline{\bar{x}}_{5}$ & $\overline{\bar{x}}_{6}$ & \multirow{2}{*}{$L_{i}$} \\
\hline \multirow{2}{*}{$\mathrm{A}_{\mathrm{p} \text {-vno }}$} & $\overline{\bar{w}}$ & 0,092 & 0,146 & 0,135 & 0,130 & 0,106 & 0,134 & \multirow{2}{*}{0,255} \\
\cline { 2 - 8 } & $\overline{\bar{b}}$ & 0,109 & 0,166 & 0,167 & 0,104 & 0,132 & 0,107 & \\
\hline \multirow{2}{*}{$\mathrm{A}_{\mathrm{p} \text {-kun }}$} & $\overline{\bar{w}}$ & 0,100 & 0,132 & 0,127 & 0,109 & 0,134 & 0,111 & \multirow{2}{*}{0,247} \\
\cline { 2 - 7 } & $\overline{\bar{b}}$ & 0,117 & 0,151 & 0,159 & 0,087 & 0,167 & 0,089 & \\
\hline \multirow{2}{*}{$\mathrm{A}_{\mathrm{p} \text {-klp }}$} & $\overline{\bar{w}}$ & 0,092 & 0,120 & 0,127 & 0,166 & 0,094 & 0,167 & \multirow{2}{*}{0,269} \\
\cline { 2 - 7 } & $\overline{\bar{b}}$ & 0,167 & 0,139 & 0,159 & 0,133 & 0,117 & 0,134 & \\
\hline
\end{tabular}

Paskutinis SAW-G metodo etapas - prioritetų eilès sudarymas, remiantis surinktų balų skaičiumi ir optimalaus (daugiausiai balų gavusio) varianto 
nustatymas. Gauta tokia prioritetų eilè: $A_{p-k l p}, A_{p-v n o}$ ir $A_{p-k u n}$, t. y. geriausia būklè po perplanavimo būtų analizuotoje Klaipèdos rajono dalyje, prastesnè Vilniuje ir prasčiausia Kaune. Lyginant su esama padetimi ir SAW prioritetais (3.20 lentelè), matyti, kad perplanavimas daugiausiai naudos atneštų Vilniui: būtų pakilta iš paskutinès vietos.

Pirmas TOPSIS grey metodo etapas - sprendimo prièmimo matricos P1p (3.10 lentelè) normalizavimas, jei pageidaujama didesnè rodiklio reikšmė (max), normalizavimas atliekamas remiantis (3.21) formule, jei mažesnè (min) - (3.22) formule. Normalizuota sprendimų prièmimų matrica P1p pateikta 3.23 lentelëje.

3.23 lentelè. TOPSIS grey normalizuota sprendimų prièmimų matrica P1p

Table 3.23. TOPSIS grey normalised decision making matrix P1p

\begin{tabular}{|l|l|l|l|l|l|l|l|}
\hline \multicolumn{2}{|l|}{ Variantas } & $\bar{x}_{1}$ & $\bar{x}_{2}$ & $\bar{x}_{3}$ & $\bar{x}_{4}$ & $\bar{x}_{5}$ & $\bar{x}_{6}$ \\
\hline \multirow{2}{*}{$\mathrm{A}_{\mathrm{p} \text {-vno }}$} & $\bar{w}$ & 0,550 & 0,882 & 0,810 & 0,406 & 0,633 & 0,441 \\
\cline { 2 - 8 } & $\bar{b}$ & 0,650 & 1,000 & 1,000 & 0,725 & 0,791 & 0,753 \\
\hline \multirow{2}{*}{$\mathrm{A}_{\mathrm{p} \text {-kun }}$} & $\bar{w}$ & 0,600 & 0,794 & 0,762 & 0,101 & 0,800 & 0,123 \\
\cline { 2 - 8 } & $\bar{b}$ & 0,700 & 0,912 & 0,952 & 0,481 & 1,000 & 0,498 \\
\hline \multirow{2}{*}{$\mathrm{A}_{\mathrm{p} \text {-klp }}$} & $\bar{w}$ & 0,550 & 0,721 & 0,762 & 0,750 & 0,561 & 0,750 \\
\cline { 2 - 8 } & $\bar{b}$ & 1,000 & 0,838 & 0,952 & 1,000 & 0,701 & 1,000 \\
\hline
\end{tabular}

$$
\begin{gathered}
\bar{w}_{i j}=\frac{w_{i j}}{\max _{i} b_{i j}} ; \bar{b}_{i j}=\frac{b_{i j}}{\max _{i} b_{i j}} ; \\
\bar{w}_{i j}=\frac{-b_{i j}}{\min _{i} w_{i j}}+2 ; \bar{b}_{i j}=\frac{-w_{i j}}{\min _{i} w_{i j}}+2 .
\end{gathered}
$$

Antras TOPSIS grey metodo etapas - normalizuotos svertinès sprendimo prièmimo matricos P1p sudarymas. Šiame etape kiekviena normalizuoto sprendimu prièmimu matricos (3.23 lentelè) rodiklio reikšmė dauginama iš atitinkamo rodiklio reikšmingumo, rezultatai pateikti 3.24 lentelèje. 
3.24 lentelè. TOPSIS grey normalizuota svertinè sprendimų prièmimų matrica P1p Table 3.24. TOPSIS grey weighted and normalised decision making matrix Plp

\begin{tabular}{|l|l|l|l|l|l|l|l|}
\hline \multicolumn{2}{|l|}{ Variantas } & $\overline{\bar{x}}_{1}$ & $\overline{\bar{x}}_{2}$ & $\overline{\bar{x}}_{3}$ & $\overline{\bar{x}}_{4}$ & $\overline{\bar{x}}_{5}$ & $\overline{\bar{x}}_{6}$ \\
\hline \multirow{2}{*}{$\mathrm{A}_{\text {p-vno }}$} & $\overline{\bar{w}}$ & 0,092 & 0,146 & 0,135 & 0,067 & 0,106 & 0,074 \\
\cline { 2 - 8 } & $\overline{\bar{b}}$ & 0,109 & 0,166 & 0,167 & 0,120 & 0,132 & 0,126 \\
\hline \multirow{2}{*}{$\mathrm{A}_{\mathrm{p} \text {-kun }}$} & $\overline{\bar{w}}$ & 0,100 & 0,132 & 0,127 & 0,017 & 0,134 & 0,020 \\
\cline { 2 - 8 } & $\overline{\bar{b}}$ & 0,117 & 0,151 & 0,159 & 0,080 & 0,167 & 0,083 \\
\hline \multirow{2}{*}{$\mathrm{A}_{\mathrm{p}-\text { klp }}$} & $\overline{\bar{w}}$ & 0,092 & 0,120 & 0,127 & 0,125 & 0,094 & 0,125 \\
\cline { 2 - 8 } & $\overline{\bar{b}}$ & 0,167 & 0,139 & 0,159 & 0,166 & 0,117 & 0,167 \\
\hline
\end{tabular}

Trečiame TOPSIS grey metodo etape pagal 3.24 lentelès duomenis sudaromi idealūs teigiami $A^{+}$((3.23) formulè) ir idealūs neigiami $A^{-}((3.24)$ formulè) variantai:

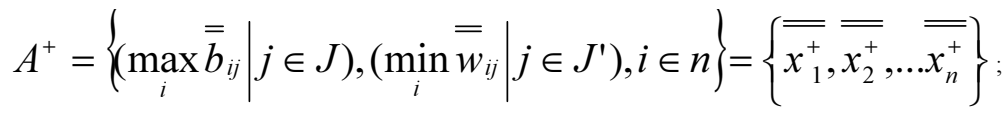

$$
\begin{aligned}
& A^{w+}=\{0,100 ; 0,146 ; 0,135 ; 0,125 ; 0,134 ; 0,125\} \text {; } \\
& A^{b+}=\{0,109 ; 0,139 ; 0,159 ; 0,080 ; 0,117 ; 0,083\} \text {; }
\end{aligned}
$$

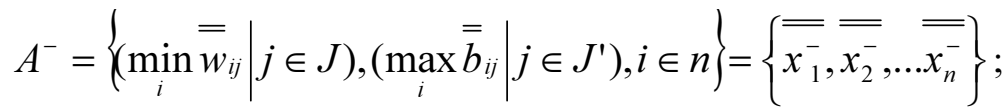

$$
\begin{aligned}
& A^{w-}=\{0,092 ; 0,120 ; 0,127 ; 0,017 ; 0,094 ; 0,020\} \text {; } \\
& A^{b-}=\{0,167 ; 0,166 ; 0,167 ; 0,166 ; 0,167 ; 0,167\} \text {. }
\end{aligned}
$$

Ketvirtas TOPSIS grey metodo etapas skirtas atstumo iki idealaus (teigiamo ir neigiamo) sprendinio apskaičiuoti. Konkretaus varianto atstumas iki idealaus teigiamo sprendinio skaičiuojamas pagal (3.25) formulę, o atstumas iki idealaus neigiamo - pagal (3.26) formulę, rezultatai pateikti 3.25 lentelèje.

$$
\begin{aligned}
& L_{i}^{+}=\sqrt{\frac{1}{2} \sum_{j=1}^{n} q_{j}\left[\left|\overline{\overline{x_{j}^{+}}}-\bar{w}_{i j}\right|^{2}+\left|\overline{\overline{x_{j}^{+}}}-\overline{\bar{b}}_{i j}\right|^{2}\right]} ; \\
& L_{i}^{-}=\sqrt{\frac{1}{2} \sum_{j=1}^{n} q_{j}\left[\left|\overline{\overline{x_{j}^{-}}}-\overline{w_{i j}}\right|^{2}+\left|\overline{\overline{x_{j}^{-}}}-\overline{\bar{b}}_{i j}\right|^{2}\right]} .
\end{aligned}
$$


3.25 lentelė. TOPSIS grey variantų atstumai iki idealaus teigiamo ir idealaus neigiamo sprendinio

Table 3.25. TOPSIS grey distance between a particular variant and the best and the worst conditions

\begin{tabular}{|l|l|l|}
\hline Variantas & $L_{i}^{+}$ & $L_{i}^{-}$ \\
\hline $\mathrm{A}_{\mathrm{p} \text {-vno }}$ & 0,075 & 0,086 \\
\hline $\mathrm{A}_{\mathrm{p}-\mathrm{kun}}$ & 0,113 & 0,098 \\
\hline $\mathrm{A}_{\mathrm{p} \text {-klp }}$ & 0,101 & 0,114 \\
\hline
\end{tabular}

Penktuoju TOPSIS grey metodo etapu, remiantis (3.27) formule, apskaičiuojamas santykinis atstumas iki idealaus sprendinio. Variantas, kurio $K_{i}$ yra arčiausiai vieneto, yra geriausias (3.26 lentelè).

$$
K_{i}=\frac{L_{i}^{-}}{L_{i}^{+}+L_{i}^{-}}, 0 \leq K_{i} \leq 1 .
$$

3.26 lentelè. TOPSIS grey santykiniai atstumai iki idealaus sprendinio

Table 3.26. TOPSIS grey similarity to the best solution

\begin{tabular}{|l|l|l|}
\hline Variantas & $K_{i}$ & Variantų prioritetai \\
\hline $\mathrm{A}_{\mathrm{p}-\mathrm{vno}}$ & 0,534 & 1 \\
\hline $\mathrm{A}_{\mathrm{p}-\mathrm{kun}}$ & 0,463 & 3 \\
\hline $\mathrm{A}_{\mathrm{p} \text {-klp }}$ & 0,530 & 2 \\
\hline
\end{tabular}

Skaičiuojant TOPSIS grey metodu nustatyta, kad geriausia būklè po perplanavimo būtų analizuotoje Vilniaus rajono dalyje, prastesné Klaipédoje ir prasčiausia Kaune. Lyginant su esama padetimi ir TOPSIS rangais (3.20 lentelè), matyti, kad perplanavimas daugiausiai naudos atneštų Vilniui: iš paskutinès vietos būtų pakilta i pirmają, o Kaunas ir Klaipeda kristų viena pozicija.

Pirmas COPRAS-G metodo etapas - sprendimo prièmimo matricos P1p (3.10 lentelè) normalizavimas, kuris atliekamas pagal (3.28) ir (3.29) formules:

$$
\bar{w}_{i j}=\frac{2 w_{i j}}{\sum_{i=1}^{m} w_{i j}+\sum_{i=1}^{m} b_{i j}} ;
$$




$$
\bar{b}_{i j}=\frac{2 b_{i j}}{\sum_{i=1}^{m} w_{i j}+\sum_{i=1}^{m} b_{i j}} .
$$

Remiantis (3.28) ir (3.29) formulèmis ir ịvertinus reikšmingumus, sudaryta COPRAS-G normalizuota svertiné sprendimu prièmimu matrica P1p (3.27 lentelè).

3.27 lentelè. COPRAS-G normalizuota svertinè sprendimų prièmimų matrica P1p Table 3.27. COPRAS-G weighted and normalised decision making matrix Plp

\begin{tabular}{|l|l|l|l|l|l|l|l|}
\hline \multicolumn{2}{|l|}{ Variantas } & $\overline{\bar{x}}_{1}$ & $\overline{\bar{x}}_{2}$ & $\overline{\bar{x}}_{3}$ & $\overline{\bar{x}}_{4}$ & $\overline{\bar{x}}_{5}$ & $\overline{\bar{x}}_{6}$ \\
\hline \multirow{2}{*}{$\mathrm{A}_{\text {p-vno }}$} & $\overline{\bar{w}}$ & 0,045 & 0,057 & 0,052 & 0,050 & 0,047 & 0,049 \\
\cline { 2 - 8 } & $\overline{\bar{b}}$ & 0,054 & 0,065 & 0,064 & 0,062 & 0,059 & 0,062 \\
\hline \multirow{2}{*}{$\mathrm{A}_{\text {p-kun }}$} & $\overline{\bar{w}}$ & 0,049 & 0,051 & 0,049 & 0,059 & 0,060 & 0,059 \\
\cline { 2 - 8 } & $\overline{\bar{b}}$ & 0,058 & 0,059 & 0,061 & 0,074 & 0,074 & 0,074 \\
\hline \multirow{2}{*}{$\mathrm{A}_{\text {p-klp }}$} & $\overline{\bar{w}}$ & 0,045 & 0,046 & 0,049 & 0,039 & 0,042 & 0,040 \\
\cline { 2 - 8 } & $\overline{\bar{b}}$ & 0,082 & 0,054 & 0,061 & 0,049 & 0,052 & 0,049 \\
\hline
\end{tabular}

Antruoju metodo etapu iš COPRAS-G normalizuotos sprendimų prièmimų matricos P1p (3.27 lentelè) išrenkamos kiekvieno varianto rodikliu minimizuojamos ir maksimizuojamos vertès, kurios atitinkamai sumuojamos remiantis (3.30) ir (3.31) formulèmis. Gaunama $S_{+i}$ (kai siekiamos didžiausios vertės) bei $S_{-i}$ (kai siekiamos mažiausios vertès), rezultatai pateikti 3.28 lentelèje.

$$
\begin{aligned}
& S_{+i}=\frac{1}{2} \sum_{j=1}^{n}\left(\bar{w}_{i j}+\overline{\bar{b}}_{i j}\right) ; \\
& S_{-i}=\frac{1}{2} \sum_{j=1}^{n}\left(\overline{\bar{w}}_{i j}+\overline{\bar{b}}_{i j}\right) .
\end{aligned}
$$


3.28 lentelè. COPRAS-G maksimizuojamos ir minimizuojamos rodiklių sumos $S_{+i}$ ir $S_{-i}$ Table 3.28. COPRAS-G maximised and minimised indicators sums $S_{+i}$ and $S_{-i}$

\begin{tabular}{|l|l|l|}
\hline Variantas & $S_{+i}$ & $S_{-i}$ \\
\hline $\mathrm{A}_{\mathrm{p} \text {-vno }}$ & 0,221 & 0,111 \\
\hline $\mathrm{A}_{\mathrm{p} \text {-kun }}$ & 0,230 & 0,133 \\
\hline $\mathrm{A}_{\mathrm{p} \text {-klp }}$ & 0,216 & 0,088 \\
\hline
\end{tabular}

Trečias COPRAS-G metodo etapas skirtas variantų prioritetų nustatymui. Prioritetų eiliškumas skaičiuojamas remiantis (3.32) formule, kuo $Q_{i}$ didesnis tuo variantas yra geresnis:

$$
Q_{i}=S_{+i}+\frac{\sum_{i=1}^{m} S_{-i}}{S_{-i} \sum_{i=1}^{m} \frac{1}{S_{-i}}} .
$$

Remiantis (3.32) formule, $Q_{p \text {-vno }}=0,328, Q_{p-k u n}=0,320$ ir $Q_{p-k l p}=0,351$, atitinkamai gaunama tokia prioritetų eilè: $A_{p-k l p}, A_{p-v n o}$ ir $A_{p-k u n}, t$. y. geriausia būklè po perplanavimo būtų analizuotoje Klaipėdos rajono dalyje, prastesné Vilniaus ir prasčiausia Kaune.

3.29 lentelè. Galutiniai SAW-G, TOPSIS grey ir COPRAS-G rezultatai (P1p) Table 3.29. Final SAW-G, TOPSIS grey and COPRAS-G results (P1p)

\begin{tabular}{|l|l|l|l|l|}
\hline Variantas & $\begin{array}{l}\text { Prioritetai } \\
\text { pagal SAW-G }\end{array}$ & $\begin{array}{l}\text { Prioritetai pagal } \\
\text { TOPSIS grey }\end{array}$ & $\begin{array}{l}\text { Prioritetai pagal } \\
\text { COPRAS-G }\end{array}$ & $\begin{array}{l}\text { Galutiniai } \\
\text { variantu } \\
\text { prioritetai }\end{array}$ \\
\hline $\mathrm{A}_{\mathrm{e}-\mathrm{vno}}$ & 2 & 1 & 2 & 2 \\
\hline $\mathrm{A}_{\mathrm{e}-\mathrm{kun}}$ & 3 & 3 & 3 & 3 \\
\hline $\mathrm{A}_{\mathrm{e}-\mathrm{klp}}$ & 1 & 2 & 1 & 1 \\
\hline
\end{tabular}

Apibendrinti SAW-G, TOPSIS grey ir COPRAS-G skaičiavimų rezultatai pateikti 3.29 lenteleje, iš jos matyti, kad po perplanavimo visais atvejais Kauno rajono dalies rezultatai būtų blogiausi, o Klaipėdoje ir Vilniuje situacija geresnè. Dviem - SAW-G ir COPRAS-G - iš trijų metodų gauti identiški rezultatai, todèl priimama, kad šiais metodais nustatyta prioritetų eilè yra korektiška: geriausia situacija, vertinant perplanavimo poveiki pagal antrame uždavinyje nurodytus rodiklius, būtų Klaipèdos rajono dalyje. 
Trečiasis uždavinys sprendžiamas trimis metodais: COPRAS, TOPSIS ir WASPAS (Staniūnas et al. 2013). COPRAS ir TOPSIS sprendimų etapai ir formulès aprašyti kartu su pirmo uždavinio sprendimu, todèl toliau pateikiami tik apibendrinti COPRAS ir TOPSIS etapu rezultatai. WASPAS metodas (Zavadskas et al. 2012) aprašomas detaliau.

Pirmas WASPAS sprendimo etapas - sprendimo prièmimo matricos P1pvc (3.11 lentelè) normalizavimas. Kadangi visų kriterijų geriausios vertès yra mažiausios normalizavimas atliekamas pagal (3.8) formulę.

Antras WASPAS sprendimo etapas - normalizuotos svertinès sprendimo prièmimo matricos Ple sudarymas. Šiame etape remiamasi (3.33) ir (3.34) formulèmis, iš kurių (3.33) skirta sumų skaičiavimui, o (3.34) sandaugų:

$$
\begin{gathered}
\overline{\bar{x}}_{i j, \text { sum }}=\bar{x}_{i j} q_{j} ; \\
\overline{\bar{x}}_{i j, \text { mult }}=\bar{x}_{i j}^{q_{j}} .
\end{gathered}
$$

Paskutinis WASPAS metodo etapas skirtas variantu prioritetams nustatyti, prioritetų eiliškumas skaičiuojamas remiantis (3.35) formule:

$$
W S P_{i}=0,5 \sum_{j=1}^{n} \bar{x}_{i j}+0,5 \prod_{j=1}^{n} \bar{x}_{i j} .
$$

COPRAS normalizuota svertinè sprendimų prièmimu matrica P1pvc pateikta 3.30 lentelejje, TOPSIS - 3.31 lenteleje ir WASPAS - 3.32 ir 3.33 lentelèse. 3.31 lentelèje papildomai nurodyti TOPSIS metodo idealus teigiamas $A^{+}$ir idealus neigiamas $A^{-}$variantai.

3.30 lentelè. COPRAS normalizuota svertinè sprendimų prièmimų matrica P1pvc Table 3.30. COPRAS weighted and normalised decision making matrix P1pvc

\begin{tabular}{|l|l|l|l|l|l|}
\hline Variantas & $\overline{\bar{x}}_{1}$ & $\overline{\bar{x}}_{2}$ & $\overline{\bar{x}}_{3}$ & $\overline{\bar{x}}_{4}$ & $\overline{\bar{x}}_{5}$ \\
\hline $\mathrm{A}_{\text {esamas }}$ & 0,094 & 0,010 & 0,094 & 0,094 & 0,094 \\
\hline $\mathrm{A}_{1}$ & 0,038 & 0,040 & 0,038 & 0,038 & 0,038 \\
\hline $\mathrm{A}_{2}$ & 0,026 & 0,047 & 0,026 & 0,026 & 0,026 \\
\hline $\mathrm{A}_{3}$ & 0,023 & 0,050 & 0,023 & 0,023 & 0,023 \\
\hline $\mathrm{A}_{4}$ & 0,019 & 0,053 & 0,019 & 0,019 & 0,019 \\
\hline
\end{tabular}


3.31 lentelè. TOPSIS normalizuota svertinè sprendimų prièmimų matrica P1pvc

Table 3.31. TOPSIS weighted and normalised decision making matrix Plpvc

\begin{tabular}{|l|l|l|l|l|l|}
\hline Variantas & $\overline{\bar{x}}_{1}$ & $\overline{\bar{x}}_{2}$ & $\overline{\bar{x}}_{3}$ & $\overline{\bar{x}}_{4}$ & $\overline{\bar{x}}_{5}$ \\
\hline $\mathrm{A}_{\text {esamas }}$ & 0,173 & 0,021 & 0,173 & 0,173 & 0,173 \\
\hline $\mathrm{A}_{1}$ & 0,069 & 0,083 & 0,070 & 0,070 & 0,070 \\
\hline $\mathrm{A}_{2}$ & 0,048 & 0,098 & 0,049 & 0,049 & 0,049 \\
\hline $\mathrm{A}_{3}$ & 0,042 & 0,104 & 0,042 & 0,042 & 0,042 \\
\hline $\mathrm{A}_{4}$ & 0,035 & 0,111 & 0,035 & 0,035 & 0,035 \\
\hline $\mathrm{A}^{+}$ & 0,035 & 0,021 & 0,035 & 0,035 & 0,035 \\
\hline $\mathrm{A}^{-}$ & 0,173 & 0,111 & 0,173 & 0,173 & 0,173 \\
\hline
\end{tabular}

3.32 lentelè. WASPAS normalizuota svertinè sprendimų prièmimų matrica P1pvc (suma)

Table 3.32. WASPAS weighted and normalised decision making matrix P1pvc (sum)

\begin{tabular}{|l|l|l|l|l|l|}
\hline Variantas & $\overline{\bar{x}}_{1}$ & $\overline{\bar{x}}_{2}$ & $\overline{\bar{x}}_{3}$ & $\overline{\bar{x}}_{4}$ & $\overline{\bar{x}}_{5}$ \\
\hline $\mathrm{A}_{\text {esamas }}$ & 0,400 & 0,200 & 0,400 & 0,400 & 0,400 \\
\hline $\mathrm{A}_{1}$ & 0,100 & 0,050 & 0,100 & 0,100 & 0,100 \\
\hline $\mathrm{A}_{2}$ & 0,143 & 0,042 & 0,143 & 0,143 & 0,143 \\
\hline $\mathrm{A}_{3}$ & 0,167 & 0,040 & 0,167 & 0,167 & 0,167 \\
\hline $\mathrm{A}_{4}$ & 0,200 & 0,037 & 0,200 & 0,200 & 0,200 \\
\hline
\end{tabular}

3.33 lentelè. WASPAS normalizuota svertinè sprendimų prièmimų matrica P1pvc (sandauga)

Table 3.33. WASPAS weighted and normalised decision making matrix P1pvc (multiplication)

\begin{tabular}{|l|l|l|l|l|l|}
\hline Variantas & $\overline{\bar{x}}_{1}$ & $\overline{\bar{x}}_{2}$ & $\overline{\bar{x}}_{3}$ & $\overline{\bar{x}}_{4}$ & $\overline{\bar{x}}_{5}$ \\
\hline $\mathrm{A}_{\text {esamas }}$ & 0,725 & 1,000 & 0,725 & 0,725 & 0,725 \\
\hline $\mathrm{A}_{1}$ & 0,871 & 0,758 & 0,871 & 0,871 & 0,871 \\
\hline $\mathrm{A}_{2}$ & 0,935 & 0,733 & 0,935 & 0,935 & 0,935 \\
\hline $\mathrm{A}_{3}$ & 0,964 & 0,724 & 0,964 & 0,964 & 0,964 \\
\hline $\mathrm{A}_{4}$ & 1,000 & 0,715 & 1,000 & 1,000 & 1,000 \\
\hline
\end{tabular}


Apibendrinti COPRAS, TOPSIS ir WASPAS skaičiavimų rezultatai pateikti 3.34 lentelèje. Iš jos matyti, kad gauta vienoda prioritetų eilè, išskyrus nedidelị nesutapimą TOPSIS metodu, kai nežymiai skiriasi 3 ir 4 varianto prioritetai. Skaičiavimai rodo, kad $\mathrm{A}_{4}$ variantas $(92 \mathrm{~mm}$ storio $\mathrm{PVC}$ rèmas su $52 \mathrm{~mm}$ dviejų kameru stiklo paketu su trimis selektyviniais stiklais), vertinant pagal P1pvc matricos rodiklius (3.11 lentelè), yra optimalus.

3.34 lentelè. Galutiniai TOPSIS, COPRAS ir WASPAS rezultatai (P1pvc)

Table 3.34. Final TOPSIS, COPRAS and WASPAS results (P1pvc)

\begin{tabular}{|l|l|l|l|l|l|l|}
\hline \multirow{2}{*}{ Variantas } & \multicolumn{2}{l|}{ COPRAS } & \multicolumn{2}{l|}{ TOPSIS } & \multicolumn{2}{l|}{ WASPAS } \\
\cline { 2 - 7 } & $Q_{i}$ & Prioritetas & $K_{i}$ & Prioritetas & $W S P_{i}$ & Prioritetas \\
\hline $\mathrm{A}_{\text {esamas }}$ & 0,088 & 5 & 0,246 & 5 & 0,318 & 5 \\
\hline $\mathrm{A}_{1}$ & 0,179 & 4 & 0,693 & 4 & 0,443 & 4 \\
\hline $\mathrm{A}_{2}$ & 0,224 & 3 & 0,753 & 3 & 0,587 & 3 \\
\hline $\mathrm{A}_{3}$ & 0,243 & 2 & 0,756 & 1 & 0,666 & 2 \\
\hline $\mathrm{A}_{4}$ & 0,265 & 1 & 0,754 & 2 & 0,776 & 1 \\
\hline
\end{tabular}

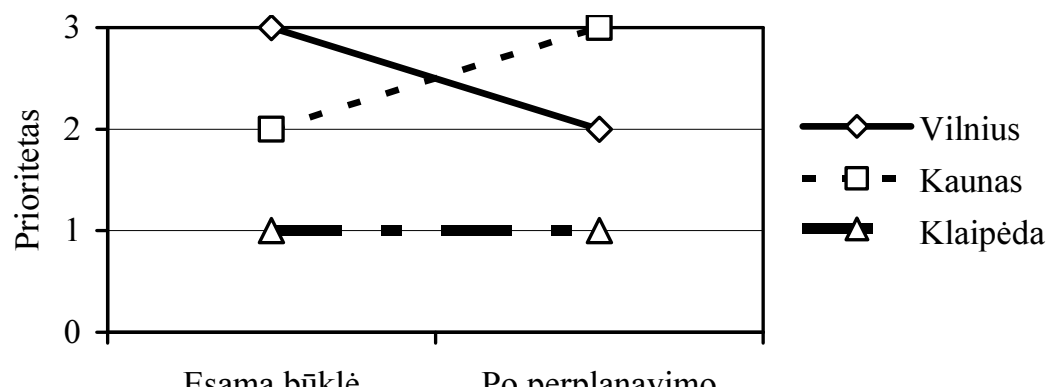

3.14 pav. Prioritetai prieš ir po perplanavimo

Fig. 3.14. Preferences before and after partial replanning

Daugiakriteris esamos būklès ir siūlomų pertvarkymų vertinimas rodo, kad esama būklè geriausia yra tirtame Klaipèdos rajone, o prasčiausia - Vilniaus, tačiau darbe siūlomi pertvarkymai esamą būklę gali pakeisti (3.14 pav.). Klaipèdos rajonas abiem atvejais užima pirmają vietą dèl gana paprastų priežasčių: mažiausio gyventoju skaičiaus, didelio želdynu ploto ir didžiausio atstumo tarp pastatų. Kauno ir Vilniaus rajonų rodiklių reikšmès skiriasi mažiau, 
tačiau Kauno rajone, skirtingai nuo Vilniaus, dalis pastatų yra devyniaaukščiai, kurie neperplanuojami pagal siūlomą modeli, o Vilniuje senuose pastatuose lieka daug mažiau gyventojų, be to, Vilniaus užstatymo intensyvumo, tankumo ir metinès emisijos rodikliai yra geresni. Skirtumai nèra esminiai, tačiau bendra suma nulèmé Vilniaus rajono pakilimą.

\subsection{Trečiojo skyriaus išvados}

1. Reguliuojant emisijas, susidarančias komunalinių atliekų sektoriuje, yra imanomas visiškas ekologinès žalos (emisijos) kompensavimas, bendruosiuose planuose rezervuojant teritorijas želdynams.

2. Apskaičiuota statistinio gyventojo emisija, susidaranti dèl komunalinių atliekų bendrojo plano sprendinių galiojimo metu, yra apie 20 tonų $\mathrm{CO}_{2}$ ekvivalento ir šiai emisijai kompensuoti reikalingas $200 \mathrm{~m}^{2}$ želdynų plotas. Didesnių miestų atveju siūloma kompensavimo plotą skirti už miesto administracinių ribų, bendradarbiaujant savivaldybèms ir apskaitą reguliuojant nacionaliniu lygmeniu.

3. Sprendžiant energetinị emisijų klausimą, nustatyta, kad Lietuvoje svarbiausia problema - esamas (sovietinis) gyvenamasis fondas. Atsižvelgiant i depopuliaciją ir migraciją, didžiausią emisiją, susidarančią dèl šildymo poreikių, ir vèliau generuos seni daugiabučiai gyvenamieji pastatai, pastatyti nuo $1961 \mathrm{~m}$. iki $1991 \mathrm{~m}$.

4. Skyriuje analizuotos dvi priemonès. Pirmoji priemonè - langų ir durų keitimas esamuose daugiabučiuose - emisiją leidžia sumažinti nuo $27 \%$ iki $36 \%$. Antroji priemoné - esamų gyvenamujų rajonų dalinis perplanavimas - tiesiogiai emisiją sumažintų dar $8 \%$ ir kartu su pirmąją priemone emisijas sumažintų nuo $35 \%$ iki $44 \%$. Abi priemonès, taikant jas vienu metu, viršytų darbe numatytus tikslus.

5. Statistinio miestiečio emisija, susidaranti dèl komunalinių atliekų, yra 3 kartus didesnè nei to paties miestiečio emisija dèl seno, neefektyvaus sovietinio daugiabučio šildymo. Pasiūlytos priemonès sudarytų sąlygas techniškai suvaldyti ir ,apkarpyti“ emisijas, tačiau rezultatai būtų dar geresni, pavykus pakeisti žmonių mąstyseną ir skatinant sąmoningumą, t. $\mathrm{y}$. technines priemones derinti su socialinèmis. 


\section{Bendrosios išvados}

1. Miestų planavimas - teisinè procedūra, tačiau ES dar nèra parengusi bendraeuropiniu teisiniu miestu valdymo priemonių, todèl visa atsakomybè tenka vietos valdžiai. LR teisès aktai, susiję su miestų planavimu ir ekologijos aspekto vertinimu, atitinka pagrindines ES nuostatas, tačiau juose trūksta aiškumo: reikalaujama ekologinių problemų miestuose sprendimų, tačiau nèra nustatyta, kas yra miesto ekologija, kokie rodikliai ją apibrezžtų, kokios būtų siektinosios vertès ir pan.

2. Remiantis užsienio patirtimi, darbe pasiūlytas miesto ekologijos modelis, sudarytas iš dviejų dalių, priklausančių nuo poveikio krypties: išorinès ir vidinès miesto ekologijos. Išorinè miesto ekologija - klimato kaita (atšilimas), sietina su miesto atliekų ir energetikos sektorių šiltnamio dujų emisija, vidinę miesto ekologiją sudaro oro kokybè ir triukšmine tarša.

3. Remiantis tarptautiniais susitarimais ir ES politika, darbe buvo nustatyti konkretūs kiekybiniai tikslai išorinès miesto ekologijos būklès gerinimui: sumažinti emisiją $8,10,20$ arba 30 procentų, skaičiuojant nuo bendrojo plano rengimo pradžios metų. Efektyviam išorinès miesto ekologijos integravimui i bendrujų planų rengimą buvo sukurtas 
skaičiavimo modelis, paremtas nuolatos miestų planavimo praktikoje naudojamu rodikliu - gyventojų skaičiumi.

4. Apskaičiuota, kad miestų bendrujų planų galiojimo laikotarpiu statistinis gyventojas išmes tokị komunalinių atliekų kiekį, kurio žala lygi vidutiniškai 19,9 tonos $\mathrm{CO}_{2}$ ekvivalento. Nustatyta, kad minètos ekologinès žalos kompensavimui būtų reikalinga $200 \mathrm{~m}^{2}$ želdynų teritorija.

5. Energetikos sektoriuje ekologinę žalą galima sumažinti pritaikius darbe siūlomus sprendimus - dalinį pastatų ir dalinị rajonų modernizavimą. Taikant pasiūlytas priemones pasirinktiems Lietuvos miestų mikrorajonams, apskaičiuota, kad emisiją galima sumažinti daugiau kaip $30 \%$, t. y. buvo pasiektas pats ambicingiausias nustatytas emisijų mažinimo tikslas. 


\section{Literatūra ir šaltiniai}

Agenda 21 - Information for Decision-Making [interaktyvus]. 2013a. [žiūrèta 2013 m. gegužès 8 d.]. Prieiga per internetą: <http://www.unep.org/documents. multilingual/default.asp? DocumentID $=52 \&$ ArticleID $=90 \& \mathrm{l}=\mathrm{en}>$.

Agenda 21 - Local Authorities 'Initiatives in Support of Agenda 21 [interaktyvus]. 2013b. [žiūrèta $2013 \mathrm{~m}$. balandžio 3 d.]. Prieiga per internetą: $<\mathrm{http}: / /$ www.unep.org/documents.multilingual/default.asp? DocumentID $=52 \&$ ArticleID= $76 \& l=\mathrm{en}>$.

Alberti, M.; Marzluff, J. M.; Shulenberger, E.; Bradley, G.; Ryan, C.; Zumbrunen, C. 2003. Integrating Humans into Ecology: Opportunities and Challenges for Studying Urban Ecosystems, BioScience 53(2): 1169-1179.

Alchimovienè, J. 2012. Daugiabučiu namu miestu gyvenamuosiuose rajonuose darnaus atnaujinimo vertinimas. Daktaro disertacija. Vilniaus Gedimino technikos universitetas. Vilnius: Technika. $143 \mathrm{p}$.

Alfa. 2013a. Renovacija neringiškiu nevilioja [interaktyvus]. [žiūrèta 2013 m. kovo 3 d.] Prieiga per internetą: <http://www.alfa.lt/straipsnis/15084960/Renovacija.neringiskiu. nevilioja $=2013-03-13 \_09-00 />$.

Alfa. 2013b. Mačiulis: Lietuvos masinès renovacijos planai - sunkiai tikètini [interaktyvus]. [žiūrèta $2013 \mathrm{~m}$. kovo $14 \mathrm{~d}$.]. Prieiga per internetą: $<\mathrm{http} / /$ www.alfa.lt/straipsnis/15085189/Maciulis..Lietuvos.masines.renovacijos.planai.. sunkiai.tiketini=2013-03-14_10-36/>. 
Aplinkos ministerija (AM). 2006. Bendra informacija. Teritoriju planavimas [interaktyvus]. [žiūrèta $2013 \mathrm{~m}$. gegužès 14 d.]. Prieiga per internetą: $<$ http://www.am.lt/VI/article.php3?article_id=4903>.

Appleton, A. F. 2006. Sustainability: A practitioner's reflection, Technology in Society 28(1-2): 3-18.

Aresta, M. 2010. Carbon Dioxide: Utilization to Reduce its Accumulation in the Atmosphere, in M. Aresta; ed. Carbon Dioxide as Chemical Feedstock. Weinheim: WILEY-VCH, 1-13.

Baldauf, R. W.; Heist, D.; Isakov, V.; Perry, S.; Hagler, G. S. W.; Kimbrough, S.; Shores, R.; Black, K.; Brixey, L. 2013. Air quality variability near a highway in a complex urban environment, Atmospheric Environment 64: 169-178.

Baltrènas, P.; Vaitiekūnas, P.; Jakštonienė, I.; Konoverskytè, S. 2012. Study of GasSolid Flow in a Multichannel Cyclone, Journal of Environmental Engineering and Landscape Management 20(2): 129-137.

Bandeira, B,; Jamet, J. J.; Jamet, D.; Ginoux, J. M. 2013. Mathematical convergence of biodiversity indices, Ecological Indicators 29: 522-528.

Barker, T., et al. 2007. Technical Summary, in B. Metz; O. R. Davidson; P. R. Bosch; R. Dave; L. A. Meyer; eds. Climate Change 2007: Mitigation. Contribution of Working Group III to the Fourth Assessment Report of the Intergovernmental Panel on Climate Change. Cambridge: Cambridge University Press, 25-93.

Bauman, Z. 2007. Globalizacija: pasekmès žmogui. Vilnius: Apostrofa. 207 p. ISBN 789955-60-537-9.

Baziene, K.; Vasarevicius, S.; Baltrenas, P.; Baltrenaite, E. 2013. Influence of total precipitation and air temperature on the composition of municipal landfill leachate, Environmental Engineering and Management Journal 12(1): 175-182.

Berg, L.; Braun, E.; Meer, J. 2004. National Urban Policies in the European Union [interaktyvus]. Rotterdam [žiūrèta $2013 \mathrm{~m}$. gegužès $10 \mathrm{~d}$.]. Prieiga per internetą: $<$ www.eukn.org/dsresource? objectid=148691 $>$.

Berwald, J.; Gedeon, T.; Sheppard, J. 2012. Using machine learning to predict catastrophes in dynamical systems, Journal of Computational and Applied Mathematics 236(9): 2235-2245.

Bijlmermeer Renovation Planning Office 2005. The Bijlmermeer Renovation. Facts \& Figures [interaktyvus]. Amsterdam [žiūrèta 2013 m. gegužès 14 d.]. Prieiga per internetą: <http://www.vernieuwdebijlmer.nl/bijlmer1 1/index.php/component/docman/ doc_download/86-the-renewal-of-the-bijlmermeer-facts-a-figures $>$.

Blom, I.; Itard, L.; Meijer, A. 2011. Environmental impact of building-related and userrelated energy consumption in dwellings, Building and Environment 46(8): 1657-1669.

Borucke, M.; Moore, D.; Cranston, G.; Gracey, K.; Iha, K.; Larson, J.; Lazarus, E.; Morales, J. C.; Wackernagel, M.; Galli, A. Accounting for demand and supply of the 
biosphere's regenerative capacity: The National Footprint Accounts' underlying methodology and framework, Ecological Indicators 24: 518-533.

Böhringer, C.; Jochem, P. E. P. 2007. Measuring the immeasurable - A survey of sustainability indices, Ecological Economics 63(1): 1-8.

Bradulienè, J.; Vasarevičius, S. 2012. The impact on grass vegetation of materials reducing gravel road dustiness, The Baltic Journal of Road and Bridge Engineering 7(4): 288-296.

Brukas, V.; Felton, A.; Lindbladh, M.; Sallnäs, O. 2013. Linking forest management, policy, and biodiversity indicators - A comparison of Lithuania and Southern Sweden, Forest Ecology and Management 291(1): 181-189.

Chen, Y. 2009. Spatial interaction creates period-doubling bifurcation and chaos of urbanization, Chaos, Solitons \& Fractals 42(3): 1316-1325.

Chen, T. 2012. Comparative analysis of SAW and TOPSIS based on interval-valued fuzzy sets: Discussions on score functions and weight constraints, Expert Systems with Applications 39(2): 1848-1861.

COWI. 2011. Lietuvos Respublikos užsienio reikalu ministerija. Lietuvos įsipareigojimu ES pereinant prie $30 \%$ išmetamu šilnamio efekta sukeliančiu duju mažinimo tikslo igyvendinimo kaštai. Galutinè ataskaita [interaktyvus]. [žiūrèta $2013 \mathrm{~m}$. gegužès $21 \mathrm{~d}$.]. Prieiga per internetą: <www.am.lt/ VI/files/File/Klimato\%20kaita/Galutine_ataskaita.pdf $>$.

Cuéllar-Franca, R.M.; Azapagic, A. 2012. Environmental impacts of the UK residential sector: Life cycle assessment of houses, Building and Environment 54(2012): 86-99

Dahl, A. L. 2012. Achievements and gaps in indicators for sustainability, Ecological Indicators, 17: 14-19.

Davis, B. N. K. 1976. Wildlife, urbanisation and industry, Biological Conservation 10(4): 249-291.

Delfi. 2013a. Klaipédiečiai jau skundžiasi galima naujos jègainès tarša [interaktyvus]. [žiūrèta $2013 \mathrm{~m}$. vasario $15 \mathrm{~d}$.]. Prieiga per internetą: <http://verslas.delfi.lt/ energetika/klaipedieciai-jau-skundziasi-galima-naujos-jegaines-tarsa.d?id=60677731 $>$.

Delfi. 2013b. Vilniaus architektas: reikia galvoti ne apie renovacija, o kaip $i$ miesta sugrąžinti žmones [interaktyvus]. [žiūrèta $2013 \mathrm{~m}$. kovo 1d.]. Prieiga per internetą: $<$ http://verslas.delfi.lt/nekilnojamas-turtas/vilniaus-architektas-reikia-galvoti-ne-apierenovacija-o-kaip-i-miesta-sugrazinti-zmones.d?id=60801399>.

Drèmaitè, M. 2006. Pigiau, daugiau, greičiau. Masinè gyvenamoji statyba ir modernizmo kanonai, Naujasis židinys-aidai 6:321-328.

Drèmaitè, M.; Petrulis, V.; Tutlytė, J. 2012. Architektūra sovietinèje Lietuvoje. Vilnius: Vilniaus dailès akademijos leidykla. 411 p. ISBN 978-609-447-024-0.

Dymova, L.; Sevastjanov, P., Tikhonenko, A. 2013. A direct interval extension of TOPSIS method, Expert Systems with Applications 40(12): 4841-4847. 
European Metropolitan Network Institute (EMI). 2012. Urban Policy is , an absolute must" on the EU-level [interaktyvus]. [žiūrèta $2013 \mathrm{~m}$. gegužès $17 \mathrm{~d}$.]. Prieiga per internetą: <http://www.emi-network.eu/Projects_Events/European_projects/EMI and URBAN Intergroup Questionnaire/Urban Policy is $\%$ E2\%80\%98an absolute must $\%$ E2\%80\%99_on_the_EU_level>.

European Commission (EC). 2010a. EUR 24353 - World and European Sustainable Cities - Insights from EU research [interaktyvus]. Luxembourg: Publications Office of the European Union [žiūrèta $2013 \mathrm{~m}$. balandžio $28 \mathrm{~d}$.]. Prieiga per internetą: <http://ec.europa.eu/research/social-sciences/pdf/sustainable-cities-report_en. pdf $>$. ISBN 978-92-79-15700-4.

European Commission (EC). 2010b. European Union legal acts [interaktyvus]. [žiūrèta 2013 m. gegužès 14 d.]. Prieiga per internetą: <http://europa.eu/legislation summaries/institutional_affairs/treaties/lisbon_treaty/ai0032_en.htm>.

European Commission (EC). 2010c. The principle of subsidiarity [interaktyvus]. [žiūrèta 2013 m. gegužès 14 d.]. Prieiga per internetą: <http://europa.eu/legislation summaries/institutional_affairs/treaties/lisbon_treaty/ai0017_en.htm $>$.

European Commission (EC). 2011. Cities of tomorrow - Challenges, visions, ways forward [interaktyvus]. Luxembourg: Publications Office of the European Union [žiūrèta $2013 \mathrm{~m}$. balandžio $29 \mathrm{~d}$.]. Prieiga per internetą: $<$ http://ec.europa.eu/regional_policy/sources/docgener/studies/pdf/citiesoftomorrow/citie softomorrow_final.pdf $>$. ISBN 978-92-79-21307-6.

European Commission (EC). 2011. Santrauka piliečiams. ES klimato ir energetikos srities teisès aktu paketas [interaktyvus]. [žiūrèta $2013 \mathrm{~m}$. gegužès 20 d.]. Prieiga per internetą: <http://ec.europa.eu/clima/summary/docs/climate_package_lt.pdf $>$.

European Commission (EC). 2012a. Urban Environment. Community Activities in the Urban Environment [interaktyvus]. [žiūrèta $2013 \mathrm{~m}$. gegužès 20 d.]. Prieiga per internetą: <http://ec.europa.eu/environment/urban/policy_initiatives.htm>

European Commission (EC). 2012b. Towards a Local Sustainability Profile - European Common Indicators - methodology sheets [interaktyvus]. [žiūrèta $2013 \mathrm{~m}$. gegužès 20 d.]. Prieiga per internetą: <http://ec.europa.eu/environment/ urban/pdf/methodology_sheet_en.pdf $>$.

European Commission (EC). 2012c. The EU Climate and Energy Package [interaktyvus]. [žiūrèta $2013 \mathrm{~m}$. gegužès $20 \mathrm{~d}$.]. Prieiga per internetą: $<$ http://ec.europa.eu/clima/policies/package/index_en.htm>.

European Commission (EC). 2012d. Europe 2020 Targets: Climate Change and Energy [interaktyvus]. [žiūrèta $2013 \mathrm{~m}$. gegužès $20 \mathrm{~d}$.]. Prieiga per internetą: $<$ http://ec.europa.eu/europe2020/pdf/themes/13_energy_and_ghg.pdf >

European Commission (EC). 2013a. Building Europe Through the Treaties [interaktyvus]. [žiūrèta $2013 \mathrm{~m}$. balandžio $28 \mathrm{~d}$.]. Prieiga per internetą: $<$ http://europa.eu/legislation_summaries/institutional_affairs/treaties/>. 
European Commission (EC). 2013b. Proposal for a new Environment Action Programme to 2020 [interaktyvus]. [žiūrèta $2013 \mathrm{~m}$. gegužès $20 \mathrm{~d}$.]. Prieiga per internetą: <http://ec.europa.eu/environment/newprg/7eap.htm>.

European Commission (EC). 2013c. Europe 2020 targets [interaktyvus]. [žiūrèta 2013 m. gegužès 20 d.]. Prieiga per internetą: < http://ec.europa.eu/europe2020/europe-2020in-a-nutshell/targets/index_en.htm>.

European Commission (EC). 2013d. Europe 2020 targets [interaktyvus]. [žiūrèta 2013 m. gegužès 20 d.]. Prieiga per internetą: <http://ec.europa.eu/europe2020/ pdf/targets_en.pdf $>$.

European Convention. 2002. The Legal Instruments: Present System CONV 50/02 [interaktyvus]. [žiūrèta $2013 \mathrm{~m}$. balandžio 29 d.]. Prieiga per internetą: <http://europeanconvention.eu.int/pdf/reg/en/02/cv00/cv00050.en02.pdf $>$.

European Environment Agency (EEA). 2011. EEA Background Information on Individual Pledges to Reduce Greenhouse Gas Emissions (measured in CO2 equivalents) [interaktyvus]. Copenhagen [žiūrèta 2013 m. gegužè 23 d.]. Prieiga per internetą: <http://ew.eea.europa.eu/BendTheTrend/pledges/eea-background-informationon-individual-pledges-to-reduce-greenhouse-gas $>$.

European Environment Agency (EEA). 2012. Greenhouse Gas Emission Trends and Projections in Europe 2012 - Tracking Progress towards Kyoto and 2020 Targets. EEA Report No 6/2012 [interaktyvus]. Copenhagen [žiūrèta 2013 m. gegužè 20 d.]. Prieiga per internetą: <http://www.eea.europa.eu/publications/ghg-trends-andprojections-2012/>.

European Environmental Bureau (EEB). 2013. Sustainability. 7th Environmental Action Programme [interaktyvus]. [žiūrèta 2013 m. gegužès 20 d.]. Prieiga per internetą: $\quad<$ http://www.eeb.org/index.cfm/activities/sustainability/7th-environmentalaction-programme/>.

Europos Komisija (EK). 2007. Europos teisminis tinklas - Teisine tvarka - Lietuva [interaktyvus]. [žiūrèta $2013 \mathrm{~m}$. gegužès $12 \mathrm{~d}$.]. Prieiga per internetą: $<$ http://ec.europa.eu/civiljustice/legal_order/legal_order_lit_lt.htm>.

Europos Sajunga (ES). 2013a. Europa - Europos Sajungos veiklos sritys [interaktyvus]. [žiūrèta $2013 \mathrm{~m}$. gegužès 14 d.]. Prieiga per internetą: <http://europa.eu/ pol/index_lt.htm>.

Europos Sajunga (ES). 2013b. Europa - Reglamentai, direktyvos ir kiti teisès aktai [interaktyvus]. [žiūrèta $2013 \mathrm{~m}$. gegužès $16 \mathrm{~d}$.]. Prieiga per internetą: $<$ http://europa.eu/about-eu/basic-information/decision-making/legal-acts/index_lt.htm>.

Eurostat. 2011a. Energy, transport and Environment Indicators. 2010 Edition [interaktyvus]. Luxembourg [žiūrèta $2013 \mathrm{~m}$. gegužès 20 d.]. Prieiga per internetą: $<$ http://epp.eurostat.ec.europa.eu/cache/ITY_OFFPUB/KS-DK-10-001/EN/KS-DK-10001-EN.PDF $>$. ISSN 1725-4566. 
Eurostat. 2011b. Waste Statistics [interaktyvus]. [žiūrèta 2011 m. sausio 11 d.]. Prieiga per internetą: <http://epp.eurostat.ec.europa.eu/statistics_explained/index.php/ Waste_statistics $>$.

Eurostat. 2012. Eurostat regional yearbook 2012 [interaktyvus]. Luxembourg: Publications Office of the European Union [žiūrèta $2013 \mathrm{~m}$. balandžio 28 d.]. Prieiga per internetą: $<$ http://epp.eurostat.ec.europa.eu/cache/ITY_OFFPUB/KS-HA-12001/EN/KS-HA-12-001-EN.PDF>. ISBN 978-92-79-24940-2.

Eurostat. 2013. Eurostat - Tables, Graphs and Maps Interface (TGM) Table. Greenhouse Gas Emissions. Total Greenhouse Gas Emissions (in CO2 equivalent) indexed to 1990. Code: tdscc100 [interaktyvus]. [žiūrèta $2013 \mathrm{~m}$. gegužès 20 d.]. Prieiga per internetą: <http://epp.eurostat.ec.europa.eu/tgm/table.do?tab=table\&init= 1 \&plugin $=1$ \&language $=$ en $\&$ pcode $=t \operatorname{sdcc} 100>$.

Flecken, U. 2005. Transformation of Prefabricated Housing Estates in Eastern Germany [interaktvus]. [žiūreta $2012 \mathrm{~m}$. kovo 26 d.]. Prieiga per internetą: <http://www.arch-ilab.polimi.it/SocialHousing/Germany_I\%20-\%20Flecken.pdf $>$.

Forster, P., et al. 2007. Changes in Atmospheric Constituents and in Radiative Forcing, in S. Solomon; D. Qin; M. Manning; Z. Chen; M. Marquis; K. B. Averyt; M. Tignor; H. L. Miller; eds. Climate Change 2007: The Physical Science Basis. Contribution of Working Group I to the Fourth Assessment Report of the Intergovernmental Panel on Climate Change. Cambridge: Cambridge University Press, 130-234.

Fruergaard, T.; Astrup, T.; Ekvall, T. 2009. Energy use and recovery in waste management and implications for accounting of greenhouse gases and global warming contributions, Waste Management \& Research 27(8): 724-737.

Gaisrinès saugos pagrindiniai reikalavimai (Žin., 2010, Nr. 146-7510), aktuali redakcija.

Gentil, E.; Christensen, T. H.; Aoustin, E. 2009. Greenhouse gas accounting and waste management, Waste Management \& Research 27(8): 696-706.

George, C.; Kirkpatrick, C.; eds. 2007. Impact Assessment and Sustainable Development: European Practice and Experience [Poveikio vertinimas ir darnus vystymasis: Europos praktika ir patirtis]. Cornwal: Edward Elgar Publishing Limited. 305 p. ISBN 978-1-84542-787-0.

Ginevičius, R.; Podvezko, V. 2007. Complex assessment of sustainable development of state regions with emphasis on ecological and dwelling conditions, Ekologija 53(2) suppl.: 41-48.

Gorte, R. W. 2009. U. S. Tree Planting for Carbon Sequestration. CRS Report for Congress [interaktyvus]. [žiūrèta $2013 \mathrm{~m}$. gegužès 21 d.]. Prieiga per internetą: $<$ http://www.fas.org/sgp/crs/misc/R40562.pdf $>$.

Grimm, N. B.; Morgan Grove, J.; Pickett, S. T. A.; Redman, C. L. 2000. Integrated Approaches to Long-Term Studies of Urban Ecological Systems, BioScience 50(7): 571-584. 
Griškevičiūtè-Gečienè, A.; Burinskienè, M. 2012. Towards Creating the Assessment Methodology for Urban Road Transport Development Projects, Technological and Economic Development of Economy 18(4): 651-671.

Hahs, A. K.; McDonnell, M. J.; Breuste, J. H. 2009. A comparative ecology of cities and towns: sybthesis of opportunities and limitations, in M. J. McDonnell; A. K. Hahs; J. H. Breuste; eds. Ecology of Cities and Towns. New York: Cambridge University Press, 575-596.

Hák, T.; Moldan, B.; Dahl, A. L.; eds. 2007. Sustainability Indicators: A Scientific Assessment. Washington: Island Press. 448 p. ISBN 978-1-59726-131-9.

Hengeveld, H.; De Vocht, C. 1982. Role of water in urban ecology, Urban Ecology 6(1-4): 5-347.

Hochuli, D. F.; Christie, F. J.; Lomov, B. 2009. Invertebrate biodiversity in urban landscapes: assessing remnant habitat and its restoration, in M. J. McDonnell; A. K. Hahs; J. H. Breuste; eds. Ecology of Cities and Towns. New York: Cambridge University Press, 215-232.

Hofmann, H. C. H. 2011. The hierarchy of sources in European Union law (before the Lisbon Treaty) [interaktyvus]. Centre Virtuel de la Connaissance sur 1'Europe [žiūrèta $2013 \mathrm{~m}$. balandžio 28 d.]. Prieiga per internetą: $<$ http://www.cvce.eu/obj/the hierarchy_of_sources_in_european_union_law_before the

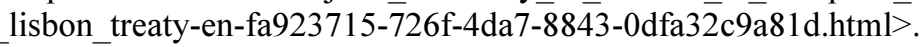

Kahalas, H.; Groves, D. L. 1978. Ecology, pollution and business: A proposed planning solution, Long Range Planning 11(6): 62-66.

Intergovernmental Panel on Climate Change (IPCC). 2007a. FAQ 10.3 If Emissions of Greenhouse are Reduced, How Quickly do Their Concentrations in the Atmosphere Decrease? [interaktyvus]. [žiūrèta 2013 m. gegužès 20 d.]. Prieiga per internetą: $<$ http://www.ipcc.ch/publications_and_data/ar4/wg1/en/faq-10-3.html s $>$.

Intergovernmental Panel on Climate Change (IPCC). 2007b. Climate Change 2007: Synthesis Report. Contribution of Working Groups I, II and III to the Fourth Assessment Report of the Intergovernmental Panel on Climate Change [interaktyvus]. Geneva: IPCC [žiūrèta 2013 m. gegužès 20 d.]. Prieiga per internetą: <http://www.ipcc.ch/publications_and_data/ar4/syr/en/contents.html $>$.

Jasiūnienè, V.; Čygas, D. 2013. Road Accident Prediction Model for the Roads of National Significance of Lithuania, The Baltic Journal of Road and Bridge Engineering 8(1): 66-73.

Jha, A. K.; Sharma, C.; Singh, N.; Ramesh, R.; Purvaja, R.; Gupta, P. K. 2008. Greenhouse gas emissions froma municipal solid waste management in Indian megacities: A case study of Chennai landfill sites, Chemosphere 71(4): 750-758.

Kaklauskas, A.; Rute, J.; Zavadskas, E. K.; Daniunas, A.; Pruskus, V.; Bivainis, J.; Gudauskas, R.; Plakys, V. 2012. Passive House model for quantitative and qualitative analyses and its intelligent system, Energy and Buildings 50: 7-18. 
Kalma, J. D.; Johnson, M.; Newcombe, K. J. 1978. Energy use and the atmospheric environment in Hong Kong: Part II. Waste heat, land use and urban climate, Urban Ecology 3(1): 59-83.

Kaplan, P.O.; DeCarolis, J.; Thorneloe, S. 2009. Is it better to burn or bury waste for clean electricity generation? Environmental Science \& Technology 43(6): 1711-1717.

Kayacan, E.; Ulutas, B.; Kaynak, O. 2010. Grey system theory-based models in time series prediction, Expert Systems with Applications 37(2):1784-1789.

Kirkeby, O. F.; Meilstrup, P. 2012. Man and the city - power to the people, $D \& A$ 17: 97-107.

Komisijos komunikatas Tarybai ir Europos Parlamentui dèl Teminès miesto aplinkos strategijos \{SEC(2006) 16\}/* KOM(2005) 718 galutinis */ [interaktyvus]. 2006. [žiūrèta $2013 \mathrm{~m}$. gegužès 12 d.]. Prieiga per internetą: <http://eurlex.europa.eu/LexUriServ/LexUriServ.do?uri=COM:2005:0718:FIN:LT:HTML>.

Komisijos komunikatas Europos Parlamentui, Tarybai, Europos ekonomikos ir socialiniu reikalu komitetui ir regioniu komitetui Galimybiu sumažinti išmetamuju šiltnamio efekta sukeliančiu duju kieki daugiau nei $20 \%$ analize ir anglies dioksido nutekejjimo rizikos vertinimas \{SEK(2010) 650\}/ * KOM(2010) 265 galutinis */ [interaktyvus]. 2010. [žiūrèta $2013 \mathrm{~m}$. gegužès 19 d.]. Prieiga per internetą: <http://eurlex.europa.eu/LexUriServ/LexUriServ.do?uri=COM:2010:0265:FIN:LT:PDF>.

Laurinavičius, A.; Miškinis, D.; Vaiškūnaitė, R.; Laurinavičius, A. 2010. Analysis and Evaluation of The Effect of Studded Tyres on Road Pavement and Environment (III), The Baltic Journal of Road and Bridge Engineering 5(3): 169-176.

Laurinavičius, A., et al. 2012. Policy Instruments for Managing EU Road Safety Targets: Road Safety Impact Assessment, The Baltic Journal of Road and Bridge Engineering 7(1): 60-67.

Lawn, P. A.; ed. 2006. Sustainable Development Indicators in Ecological Economics [Darnaus vystymosi indikatoriai ekologinejje ekonomikoje]. Cornwal: Edward Elgar Publishing Limited. 467 p. ISBN 978-1-84542-099-4.

Leipcigo tvariujų Europos miestu chartija [interaktyvus]. 2007. [žiūrèta $2013 \mathrm{~m}$. balandžio 27 d.]. Prieiga per internetą: <http://www.am.lt/VI/files/ 0.917593001243239525.pdf>.

Lietuvos Respublikos aplinkos ministerija (LR AM). 2012. Bendra informacija [interaktyvus]. [žiūrèta $2013 \mathrm{~m}$. gegužès $21 \mathrm{~d}$.]. Prieiga per internetą: $<$ http://www.am.lt/VI/rubric.php3?rubric_id=1040>.

Lietuvos Respublikos teritorijų planavimo įstatymas (Žin., 1995, Nr. 107-2391), aktuali redakcija.

Lietuvos Respublikos želdynų įstatymas (Žin., 2007, Nr. 80-3215), aktuali redakcija.

Lietuvos statistikos departamentas (LSD). 2011a. Kuro ir energijos balansas 2010 [interaktyvus]. [žiūrèta $2012 \mathrm{~m}$. gegužès $18 \mathrm{~d}$.]. Prieiga per internetą: $<$ http://web.stat.gov.lt/lt/catalog/pages_list/?id=1566\&PHPSESSID=twmjcujxideyz $>$. 
Lietuvos statistikos departamentas (LSD). 2011b. Energijos sunaudojimas namu ūkiuose 2009 [interaktyvus]. [žiūrèta $2012 \mathrm{~m}$. gegužès 18 d.]. Prieiga per internetą: $<$ http://web.stat.gov.lt/lt/catalog/pages_list/?id=1566\&PHPSESSID=twmjcujxideyz $>$.

Lietuvos statistikos departamentas (LSD). 2013. Gyventoju skaičius metu pradžioje (perskaičiuotas po $2011 \mathrm{~m}$. surašymo) [interaktyvus]. [žiūrèta $2013 \mathrm{~m}$. gegužès $21 \mathrm{~d}$.]. Prieiga per internetą: <http://web.stat.gov.lt/lt/pages/view/?id=2420>.

Lietuvos šilumos tiekèjų asociacija (LSTA). 2012. Šilumos tiekimo bendrovių 2011 metu ūkinès veiklos apžvalga [interaktyvus]. Vilnius [žiūrèta $2013 \mathrm{~m}$. gegužès $21 \mathrm{~d}$.]. Prieiga per internetą: <http://www.lsta.lt/files/statistika/2011_statistika.pdf>.

Lloyd-Jones, T. 2004. Urban Design for Sustainability: Final Report of the Working Group on Urban Design for Sustainability to the European Union Expert Group on the Urban Environment [interaktyvus]. [žiūrèta 2010 m. rugsejjo 8 d.]. Prieiga per internetą: $<$ http://www.baltic21.org/attachments/jo4_eci_study_report.pdf $>$.

Manfredi, S. 2009. Environemental Assessment of Solid Waste Landfilling in a Life Cycle Perspective (LCA Model EASEWASTE). PhD Thesis. Technical University of Denmark. Virum: Vester Kopi. 88 p.

Manfredi, S.; Tonini, D.; Christensen, T. H.; Scharf. H. 2009. Landfilling of waste: accounting of greenhouse and global warming contributions, Waste Management \& Research 27(8): 825-836.

Marinoni, O.; Higgins, A.; Coad, P.; Garcia, J. N. 2013. Directing urban development to the right places: Assessing the impact of urban development on water quality in an estuarine environment, Landscape and Urban Planning 113: 62-77.

Mayer, A. L. 2008. Strength and weaknesses of common sustainability indices for multidimensional systems, Environment International 34(2): 277-291.

McDonnell, M. J; Hahs, A. K.; Breuste, J. H.; eds. 2009. Ecology of Cities and Towns [Miestų ir miestelių ekologija]. New York: Cambridge University Press. 714 p. ISBN 978-0-521-67833-9.

McMichael, A. J.; Campbell-Lendrum, D. H.; Corvalán C. F.; Ebi, K. L.; Githeko, A. K.; Scheraga, J. D.; Woodward, A.; eds., 2003. Climate change and human healthrisks and reponses [interaktyvus]. Geneva: World Health Organization [žiūrèta $2013 \mathrm{~m}$. gegužès $20 \mathrm{~d}$.]. Prieiga per internetą: $<$ http://www.who.int/globalchange/publications/climchange.pdf $>$.

Medineckienè, M.; Turskis, Z.; Zavadskas, E. K. 2010. Sustainable construction taking into account the building impact on the environment, Journal of environmental engineering and landscape management 18(2): 118-127.

Miesto renovacija. 2011. 2010 metais atnaujintu (modernizuotu) daugiabučiu namu atnaujinimo (modernizavimo) programos igyvendinimo stebèsena [interaktyvus]. Vilnius [žiūrèta $2013 \mathrm{~m}$. gegužès $23 \mathrm{~d}$.]. Prieiga per internetą: <http://www.atnaujinkbusta.lt/ public/gallery/studijos_dokumentai/2010StebesenosAtaskaita\%2002-01.pdf>. 
Miestų ir miestelių teritorijų bendrujų planų rengimo taisyklès (Žin., 2006, Nr. 1455559), aktuali redakcija.

Millenium Ecosystem Assessment. 2005. Ecosystems and Human Well-being: Synthesis [interaktyvus]. Washington: Island Press. [žiūrèta 2013 m. gegužès 12 d.]. Prieiga per internetą: < http://www.millenniumassessment.org/documents/document.356.aspx.pdf>. ISBN 1-59726-040-1.

Miškinis, A. 1990. Lietuvos urbanistika: istorija, dabartis, ateitis. Vilnius: Mintis. 154 p. ISBN 5-417-00124.

Miško atkūrimo ir ịveisimo nuostatai (Žin., 2008, Nr. 45-1702), aktuali redakcija.

Moore, J.; Kissinger, M.; Rees, W. 2013. An urban metabolism and ecological footprint assessment of Metro Vancouver, Journal of Environmental Management 124(30): 51-61.

Mori, K.; Christodoulou, A. 2012. Review of sustainability indices and indicators: Towards a new City Sustainability Index (CSI), Environmental Impact Assessment Review 32(1): 94-106.

Morse, S. 2004. Indices and Indicators in Development: An Unhealthy Obsession with Numbers?. London: Earthscan. 221 p. ISBN 1-84407-011-5

Morse, S.; Fraser, E. D. G. 2005. Making 'dirty' nations look clean? The nation state and the problem of weighting indices as tools for measuring progress towards sustainability, Geoforum 36(5): 625-640.

Morse, S. 2006. Is Corruption Bad for Environmental Sustainability? A Cross-National Analysis, Ecology and Society 11(1): 22.

Nacionalinė darnaus vystymosi strategija (Žin., 2003, Nr. 89-4029; 2009, Nr. 121-5215).

Niccolucci, V.; Tiezzi, E.; Pulselli, F. M.; Capineri, C. 2012. Biocapacity vs Ecological Footprint of world regions: A geopolitical interpretation, Ecological Indicators 16: 23-30.

Niemelä, J.; Kotze, D. J.; Yli-Pelkonen, V. 2009. Comparative urban ecology: challenges and possibilities, in M. J. McDonnell; A. K. Hahs; J. H. Breuste; eds. Ecology of Cities and Towns. New York: Cambridge University Press, 9-24.

Nijkamp, P.; Reggiani, A. 1995. Non-linear evolution of dynamic spatial systems. The relevance of chaos and ecologically-based models, Regional Science and Urban Economics 25(2): 183-210.

Organisation for Economic Development and Co-operation (OECD). 2003. OECD Environmental Indicators. Development, Measurement and Use [interaktyvus]. [žiūrèta 2013 m. gegužès 20 d.]. Prieiga per internetą: $<$ http://www.oecd.org/environment/indicators-modelling-outlooks/24993546.pdf>.

Organisation for Economic Development and Co-operation (OECD). 2008. OECD Key Environmental Indicators [interaktyvus]. [žiūrèta $2010 \mathrm{~m}$. rugsejjo 22 d.]. Prieiga per internetą: < http://www.oecd.org/dataoecd/20/40/37551205.pdf >. 
OL C 83. 2010. Europos Sajungos sutarties ir Sutarties dèl Europos Sajungos veikimo suvestinès redakcijos [interaktyvus]. [žiūrèta 2013 m. gegužès 15 d.]. Prieiga per internetą: < http://eur-lex.europa.eu/>.

OL L 140. 2009. $2009 \mathrm{~m}$. balandžio 23 d. Europos Parlamento ir Tarybos sprendimas Nr. 406/2009/EB [interaktyvus]. [žiūrèta 2013 m. gegužès 15 d.]. Prieiga per internetą: < http://eur-lex.europa.eu/>.

Paožalytè, I.; Grubliauskas, R.; Vaitiekūnas, P. Modelling the noise generated by railway transport: statistical analysis of modelling results applying CADNAA and IMMI programs, Journal of Environmental Engineering and Landscape Management 20(3): 206-212.

Park, J. W.; Shin, H. C. 2001. Surface emission of landfill gas from solid waste landfill Atmospheric Environment, 35(20): 3445-3451.

Parry, E. J. 2007. The Greatest Threat to Global Security: Climate Change Is not Merely an Environmental Problem [interaktyvus]. [žiūrèta $2012 \mathrm{~m}$. vasario 9 d.]. Prieiga per internetą: <http://www.un.org/wcm/content/site/chronicle/cache/bypass/home/archive/ issues2007/pid/4825?ctnscroll_articleContainerList=1_0\&ctnlistpagination_articleConta inerList $=$ true $>$.

Pickett, S. T. A.; Cadenasso, M. L.; McDonnell, M. J.; Burch, W. R. 2009. Frameworks for urban ecosystem studies: gradients, patch dynamics and the human ecosystem in the New York metropolitan area and Baltimore, USA, in M. J. McDonnell; A. K. Hahs; J. H. Breuste; eds. Ecology of Cities and Towns. New York: Cambridge University Press, 25-50.

Planų ir programų strateginio pasekmių aplinkai vertinimo tvarkos aprašas (Žin., 2004, Nr. 130-4650), aktuali redakcija.

Rapoport, A. 1983. The ecology of a city and its people (the case of Hong Kong): S. Boyden, S. Millar, K. Newcombe and B. O`Neill. Australian National University Press, Canberra/London/Miami, 1981. A\$ 17.50, Urban Ecology 7(4): 365-367.

Richarz, C.; Schulz, C.; Zeitler, F. 2007. Energy-Efficiency Upgrade [Energijos efektyvumo patobulinimas]. Birkhäuser. 112 p. ISBN 978-3-7643-8121-9.

Rogoža, A.; Martinaitis, V. 2007. Daugiabučiu namu modernizavimo programos monitoringas [interaktyvus]. Vilnius [žiūrèta $2013 \mathrm{~m}$. gegužès $23 \mathrm{~d}$.]. Prieiga per internetą: <http://www.am.lt/files/Monitoringas_2007.pdf >.

Rogoža, A.; Šiupšinskas, G.; Martinaitis, V. 2008. Daugiabučiu namų modernizavimo programos monitoringas (2 etapas) [interaktyvus]. Vilnius [žiūrèta $2012 \mathrm{~m}$. kovo $28 \mathrm{~d}$.]. Prieiga per internetą: <http://www.am.lt/VI/files/0.888292001235479201.pdf >.

Salminen, S.; Joas, M. 2002. Baltic 21 Pre-Feasibility Study Report: European Common Indicators in Monitoring Baltic 21 in Cities [interaktyvus]. Turku: Union of the Baltic Cities (UBC) [žiūrèta $2011 \mathrm{~m}$. balandžio $11 \mathrm{~d}$.]. Prieiga per internetą: $<$ http://www.baltic21.org/attachments/jo4_eci_study_report.pdf $>$. 
Scheutz, C.; Kjeldsen, P.; Gentil, E. 2009. Greenhouse gases, radiative forcing, global warming potential and waste management - an introduction, Waste Management \& Research 27(8): 716-723.

Sharifi, A.; Murayama, A. 2013. A critical review of seven selected neighborhood sustainability assessment tools, Environmental Impact Assessment Review 38: 73-87

Siche, J. R.; Agostinho, F.; Ortega, E.; Romeiro, A. 2008. Sustainability of nations by indices: Comparative study between environmental sustainability index, ecological footprint and the emergy performance indices, Ecological Economics 66(4): 628-637.

Singh, R. K.; Murty, H. R.; Gupta, S. K.; Dikshit, A. K. 2009. An overview of sustainability assessment mthodologies, Ecological Indicators 9(2): 189-212.

Singh, R. K.; Murty, H. R.; Gupta, S. K.; Dikshit, A. K. 2012. An overview of sustainability assessment mthodologies, Ecological Indicators 15(1): 281-299.

Steele, J. Ecological Architecture. A Critical History. London: Thames \& Hudson. 272 p. ISBN 978-0-500-34210-7.

STR. 2.02.01:2004 „Gyvenamieji pastatai“, 2013 m. aktuali redakcija.

STR 2.06.01:1999 „Miestų miestelių ir kaimų susisiekimo sistemos“, 2013m. aktuali redakcija.

Šaparauskas, J. 2004. Multi-attribute evaluation and modelling of sustainable urban development: Summary of Doctoral Dissertation. Vilnius Gediminas Technical University. Vilnius: Technika. $32 \mathrm{p}$.

Tarzia, V.; ed. 2003. European Common Indicator: Towards a Local Sustainability Profile [interaktyvus]. Milano: Ancora Arti Grafiche [žiūrèta 2013 m. gegužès 20 d.]. Prieiga per internetą: $<$ http://euronet.uwe.ac.uk/www.sustainablecities.org/indicators/ECI\%20Final\%20Report.pdf?.

Teritorijų planavimo dokumentų sprendinių poveikio vertinimo tvarkos aprašas (Žin., 2004, Nr. 113-4228), aktuali redakcija.

The Cities Alliance. 2007. Liveable Cities: The Benefits of Urban Environmental Planning. A Cities Alliance Study on Good Practices and Useful Tools [interaktyvus]. Washington [žiūrèta $2010 \mathrm{~m}$. rugsèjo $8 \mathrm{~d}$.]. Prieiga per internetą: $<$ http://www.unep.org/urban_environment/PDFs/LiveableCities.pdf $>$.

Themelis, N. J.; Ulloa, P. A. Methane generation in landfills, Renewable Energy 32(7): 1243-1257.

United Nations (UN). 2010. 2009 Revision of World Urbanization Prospects [interaktyvus]. [žiūrèta $2012 \mathrm{~m}$. sausio $7 \mathrm{~d}$.]. Prieiga per internetą: $<$ http://esa.un.org/unpd/wup/Documents/WUP2009_Press-Release_Final_Rev1.pdf > .

United Nations (UN). 2011a. The History of Sustainable Development in the United Nations [interaktyvus]. [žiūrèta $2013 \mathrm{~m}$. gegužès 10 d.]. Prieiga per internetą: $<$ http://www.uncsd2012.org/history.html >. 
United Nations (UN). 2011 b. About the Rio+20 Conference interaktyvus]. [žiūrèta 2013 m. gegužès 19 d.]. Prieiga per internetą: < http://www.uncsd2012.org/about.html>.

United Nations Environment Programme (UNEP). 2011. Waste and Climate Change. Global Trends and Strategy Framework [interaktyvus]. [žiūrèta 2013 m. gegužès 19 d.]. Prieiga per internetą: <http://www.unep.or.jp/ietc/Publications/spc/Waste\& ClimateChange/Waste\&ClimateChange.pdf $>$.

UNEP; UNICEF; WHO. 2002. Children in the New Millenium: Environmental Impact on Health [interaktyvus]. [žiūrèta $2012 \mathrm{~m}$. vasario $9 \mathrm{~d}$.]. Prieiga per internetą: $<$ http://www.who.int/water_sanitation_health/hygiene/settings/millennium/en/ $>$.

United States Environmental Protection Agency (U. S. EPA). 2000. Facts About Landfill Gas [interaktyvus]. [žiūrèta 2013 m. gegužès 15 d.]. Prieiga per internetą: $<$ http://www.dem.ri.gov/programs/benviron/waste/central/lfgfact.pdf $>$.

United States Environmental Protection Agency (U. S. EPA). 2006. Solid Waste Management and Greenhouse Gases. A Life-Cycle Assessment of Emissions and Sinks [interaktyvus]. [žiūrèta $2013 \mathrm{~m}$. sausio $5 \mathrm{~d}$.]. Prieiga per internetą: $<$ http://www.epa.gov/climatechange/wycd/waste/downloads/fullreport.pdf $>$.

United States Environmental Protection Agency (U. S. EPA). 2008a. Climate Leaders Greenhouse Gas Inventory Protocol - Offset Project Methodology - for Project Type: Reforestation/Afforestation [interaktyvus]. [žiūrèta $2013 \mathrm{~m}$. sausio $5 \mathrm{~d}$.]. Prieiga per internetą: <http://www.epa.gov/climateleadership/documents/ resources/draft_reforestation_offset_protocol.pdf $>$.

United States Environmental Protection Agency (U. S. EPA). 2008b. Background Information Document for Updating AP42 Section 2.4 for Estimating Emissions from Municipal Solid Waste Landfills. EPA/600/R-08-116 [interaktyvus]. Washington [žiūrèta $2013 \mathrm{~m}$. gegužès $21 \mathrm{~d}$.]. Prieiga per internetą: $<$ http://www.epa.gov/ttn/chief/ap42/ch02/draft/db02s04.pdf $>$.

United States Environmental Protection Agency (U. S. EPA). 2012. Interactive Units Converter. Coalbed Methane Outreach Program (CMOP) [interaktyvus]. [žiūrèta $2013 \mathrm{~m}$. gegužès $21 \mathrm{~d}$.]. Prieiga per internetą: $<$ http://www.epa.gov/cmop/resources/converter.html $>$.

United States Environmental Protection Agency (U. S. EPA). 2013. History of Sustainability. Creation of EPA and NEPA [interaktyvus]. [žiūrèta $2013 \mathrm{~m}$. vasario $22 \mathrm{~d}$.]. Prieiga per internetą: <http://yosemite.epa. gov/r10/oi.nsf/8bb15fe43a5fb81788256b58005ff079/398761d6c3c7184988256fc400784 $99 \mathrm{~b}$ !OpenDocument $>$.

United Nations (UN). 2012. Doha Amendment to the Kyoto Protocol [interaktyvus]. [žiūrèta $2013 \mathrm{~m}$. gegužè $20 \mathrm{~d}$.]. Prieiga per internetą: $<$ http://treaties.un.org/doc/Publication/CN/2012/CN.718.2012-Eng.pdf $>$

United Nations Framework Convention on Climate Change (UNFCCC). 2009. Summary of GHG Emissions for European Union (27) [interaktyvus]. [žiūrèta 2012 m. 
vasario 7 d.]. Prieiga per internetą: <http://unfccc.int/files/ghg_data/ghg_data_unfccc/ ghg_profiles/application/pdf/eu-27_ghg_profile.pdf $>$.

United Nations Framework Convention on Climate Change (UNFCCC). 2013a. Fast Facts \& Figures [interaktyvus]. [žiūrèta 2013 m. gegužès 20 d.]. Prieiga per internetą: $<$ http://unfccc.int/essential_background/basic_facts_figures/items/6246.php $>$.

United Nations Framework Convention on Climate Change (UNFCCC). 2013b. Kyoto Protocol to the United Nations Framework Convention on Climate Change [interaktyvus]. [žiūrèta 2013 m. gegužès 20 d.]. Prieiga per internetą: $<$ http://unfccc.int/essential_background/kyoto_protocol/items/1678.php>

United Nations Framework Convention on Climate Change (UNFCCC). 2013c. Kyoto Protocol [interaktyvus]. [žiūrèta $2013 \mathrm{~m}$. gegužès 20 d.]. Prieiga per internetą: $<$ http://unfccc.int/kyoto_protocol/items/2830.php $>$

Vaiškūnaitè, R.; Mierauskas, P.; Špakauskas, V. 2012. Biodiversity impact assessment in road development in Lithuania, Transport 27(2): 187-195.

Valstybinis strateginis atliekų tvarkymo planas (VSATP) (Žin., 2002, Nr. 40-1499), aktuali redakcija.

Vanagas, J. 1974. Lazdynu gyvenamojo rajono urbanistiniai sociologiniai tyrimai: Lietuvos miestu gyvenamuju rajonu planavimo tobulinimas: ataskaita. Vilniaus inžinerinis statybos institutas, $112 \mathrm{p}$.

Vanagas, J. 1980. Naujo gyvenamojo rajono eksploatavimo efektyvumo nustatymas. Karoliniškiu ir Viršuliškiu rajonu urbanistiniai-sociologiniai tyrimai: ataskaita. Vilniaus inžinerinis statybos institutas, $110 \mathrm{p}$.

Vanagas, J. 1992. Miesto gyvenamosios aplinkos formavimas: sociologinis aspektas. Vilnius: Technika. $176 \mathrm{p}$.

Vanagas, J. 1996. Miesto sociologijos pagrindai. Vilnius: Aldorija. 147 p.

Verbeeck, G.; Hens, H. 2010. Life cycle inventory of buildings: A contribution analysis, Building and Environment 45(4): 964-967.

Verma, S. 2002. Anaerobic Digestion of Biodegradable Organics in Municipal Solid Wastes [interaktyvus]. [žiūrèta 2013 m. gegužès 21 d.]. Prieiga per internetą: $<$ http://www.seas.columbia.edu/earth/vermathesis.pdf $>$.

Vitousek, P. M.; Mooney, H. A.; Lubchenco, J.; Melillo, J. 1997. Human domination on Earth's ecosystem, Science 277: 494-499.

Wackernagel, M.; Monfreda, C. 2004. Ecological Footprints and Energy, in C. J. Cleveland; ed. Encyclopedia of Energy. Elsevier, 1-11.

Wackernagel, M., et al. 2005. Europe 2005: The Ecological Footprint [interaktyvus]. Brussels [žiūrèta $2013 \mathrm{~m}$. gegužès $12 \mathrm{~d}$.]. Prieiga per internetą: $<$ http://www.footprintnetwork.org/images/uploads/Europe_2005_Ecological_Footprint.p df $>$. ISBN 2-88085-268-4. 
Wallhagen, M.; Glaumann, M.; Malmqvist, T. 2011. Basic building life cycle calculations to decrease contribution to climate change - Case study on an office building in Sweden, Building and Environment 46(10): 1863-1871.

White, M. A. 2013. Sustainability: I know it when I see it, Ecological Economics 86: 213-217.

Wien Energie. 2012. History [interaktyvus]. [žiūrèta 2013 m. gegužès 21 d.]. Prieiga per internetą: <http://www.wienenergie.at/eportal/ ep/contentView.do/pageTypeId/19118/programId/19742/contentTypeId/1001/channelId/ $-28277 /$ contentId/21074>.

Wilson, A. G. 2002. Complex spatial systems: Challenges for modellers, Mathematical and Computer Modelling 36(3): 379-387.

Witte, B. 2008. Legal instruments and Law-Making in the Lisbon Treaty, in S. Griller; J. Ziller; eds. The Lisbon Treaty. Vienna: Springer, 79-108.

Wittig, R. 2009. What is the main object of urban ecology? Determining demarcation using the example of research into urban flora, in M. J. McDonnell; A. K. Hahs; J. H. Breuste; eds. Ecology of Cities and Towns. New York: Cambridge University Press, 523-529.

Yin, M. 2013. Fifteen years of grey system theory research: A historical review and bibliometric analysis, Expert Systems with Applications 7(1): 2767-2775.

Zagorskas, J. 2007. Miestų kompaktiškumas ir darniosios plètros modeliavimas. Daktaro disertacija. Vilniaus Gedimino technikos universitetas. Vilnius. 123 p.

Zavadskas, E. K.; Viteikienè, M.; Šaparauskas, J. 2007a. Sustainable development assessment of cities and their residential districts, Ekologija 53(2) suppl.: 49-54.

Zavadskas, E. K.; Kaklauskas, A.; Šaparauskas, J.; Kalibatas, D. 2007b. Vilnius urban sustainability assessment with an emphasis on pollution, Ekologija 53(2) suppl.: 64-72.

Zavadskas, E, K.; Kaklauskas, A.; Turskis, Z.; Tamošaitienė, J. 2008. Selection of the effective dwelling house walls by applying attributes values determined at intervals, Journal of Civil Engineering and Management 4(2): 85-93.

Zavadskas, E. K.; Turskis, Z.; Tamošaitienè, J. 2010a. Risk assessment of construction projects, Journal of Civil Engineering and Management 16(1): 33-46.

Zavadskas, E. K.; Vilutienè, T.; Turskis, Z.; Tamosaitiene, J. 2010b. Contractor selection for construction works by applying SAW-G and TOPSIS grey techniques, Journal of Business Economics and Management 11(1): 34-55.

Zavadskas, E. K.; Turskis, Z.; Antucheviciene, J. 2012. Optimization of Weighted Aggregated Sum Product Assessment, Electronics and Electrical Engineering 122(6): 3-6. 



\section{Autoriaus mokslinių publikacijụ disertacijos tema sąrašas}

\section{Straipsniai recenzuojamuose mokslo žurnaluose}

Staniūnas, M.; Staniūnas, E. K.; Burinskienè, M. 2010. Application of indices for assessing the ecological potential of urban development, Ekologija 56(3-4): 79-86. ISSN 2029-0586. (ISI Master Journal List; CSA; VINITI).

Staniūnas, M.; Burinskienè, M.; Malienè, V. 2012. Ecology in urban planning: mitigating the environmental damage of municipal solid waste, Sustainability 4(9): 1966-1983. ISSN 2071-1050. (EBSCOhost; CABI; CSA; TOC Premier).

Staniūnas, M. 2012. Ecology of city: levels and components, Journal of Sustainable Architecture and Civil Engineering 1(1): 26-32. ISSN 2029-9990. (EBSCOhost; CABI; CSA; TOC Premier).

Staniūnas, M.; Medineckienè, M.; Zavadskas, E. K. 2013. To modernize or not: ecological-economical assessment of multi-dwelling houses modernization, Archives of Civil and Mechanical Engineering 13(1): 88-98. ISSN 1644-9665. (Science Citation Index Expanded (Web of Science)). 


\section{Straipsniai kituose leidiniuose}

Staniūnas, M.; Burinskienè, M. 2011a. Assessment of greenhouse gases attributable to the waste management sector in urban planning, in 8th International Conference "Environmental Engineering”: selected papers, vol. 3. ed. by D. Čygas, K. D. Froehner. May 19-20, 2011, Vilnius, Lithuania. Vilnius: Technika, 986-992. ISBN 978-9955-28826-8. [Duomenų bazès: Conference Proceedings Citation Index].

Staniūnas, M.; Burinskienè, M. 2011b. Assessment of greenhouse gases attributable to the waste management sector in urban planning, in 8th International Conference "Environmental Engineering”, ed. by D. Čygas, K. D. Froehner. May 19-20, 2011, Vilnius, Lithuania CD. Vilnius: Technika, 986-992. ISBN 978-9955-28-831-2.

Staniūnas, M.; Staniūnas, E. K. 2011. Urban planning and ecology: Lithuanian practice, in "Ecological Architecture 2011". October 13, 2011, Kaunas, Lithuania. Kaunas: Technologija, 18-23. ISBN 978-609-02-0164-0. 
Mindaugas STANIŪNAS

EKOLOGIJOS ASPEKTO VERTINIMAS MIESTU BENDRUOSIUOSE PLANUOSE

Daktaro disertacija

Technologijos mokslai,

statybos inžinerija $(02 \mathrm{~T})$

\section{ECOLOGICAL ASSESSMENT IN URBAN COMPREHENSIVE PLANS}

Doctoral Dissertation

Technological Sciences,

Civil Engineering (02T)

$20131007.11,25$ sp. I. Tiražas 20 egz.

Vilniaus Gedimino technikos universiteto

leidykla „Technika“,

Saulètekio al. 11, 10223 Vilnius,

http://leidykla.vgtu.lt

Leidinys atspausdintas ant $100 \%$ perdirbto popieriaus

Spausdino UAB "Ciklonas"

J. Jasinskio g. 15, 01111 Vilnius 
